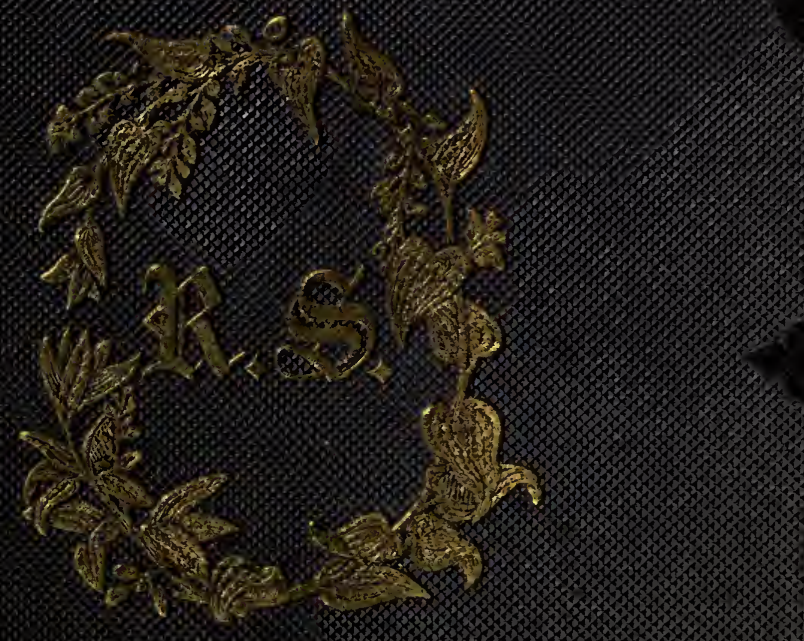

s. 


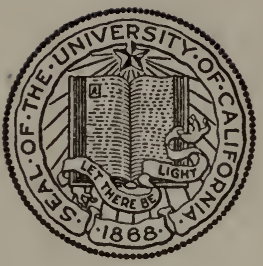

\section{THE LIBRARY \\ OF THE UNIVERSITY OF CALIFORNIA \\ DAVIS}





$$
4 / 40
$$




\section{THE}

\section{R A Y S O C I E TY.}

INSTITUTED MDCCCXLIV.

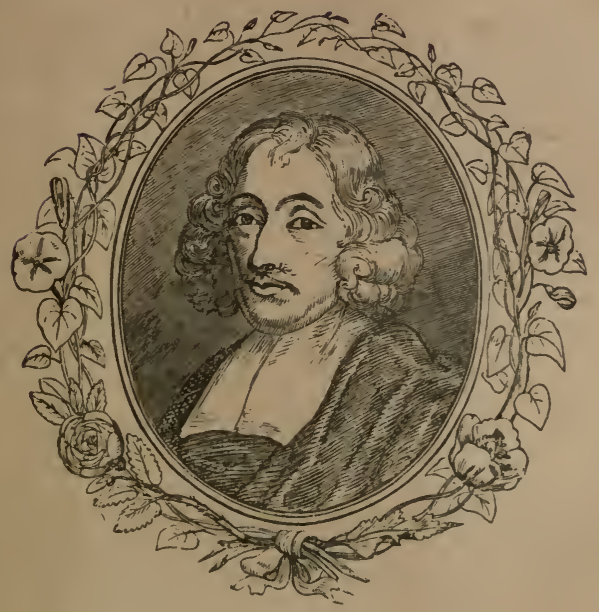

T'his volume is issued to the Subscribers to the RAY SocIETY for the Year 1912.

L O N D O N :

MCMIXIII. 
Digituzect oy the Intemei trane in 2697 wits fundin L liom Nugresori Gorodiaten 


\section{THE \\ BRITISH \\ PARASITIC COPEPODA}

BY

THOMAS SCOTT, LL.D., F.L.S.

AND

ANDREW SCOTT, A.L.S.

VOLUME I

COPEPODA PARASITIC ON FISHES

TEXT

L O N D O N

PRIN'TED FOR THE RAY SOCIE'TY

AND SOLD BY

DULAU \& CO., LTD., 37, SOHO SQUARE, W.

$\overline{1913}$ 
PRINTED BY ADLARD AND SON LONDON AND DORKING 


\section{THE AUTHORS}

DESIRE, WITH THE MOST SINCERE RESPECT, TO DEDICATE THIS WORK

TO THE

REV. CANON A. M. NORMAN, M.A., D.C.L., LL.D., F.R.S., F.L.S., ETC., IN GRATITUDE FOR HIS UNFAILING KINDNESS AND ASSISTANCE EXTENDED TO THEM FOR MANY YEARS. 



\section{PREFACE.}

Dr. Baird's work on 'The Natural History of the British Entomostraca,' published by the Ray Society in 1850, marked an important stage in British Natural History research, and forms the basis of the present volume. That work contains a complete account of the Copepoda found living as parasites on British fishes, so far as then known. Much has been done since then to extend our knowledge of these organisms, and many species have been added to the number recorded by Dr. Baird. His work naturally tended to produce such results, for it placed before British students, in a concise manner, a large amount of interesting information concerning these parasitic forms, and, by showing the successful results which had already been accomplished in other countries among such curious animals, led to an increased interest in their study.

'A Monograph of the Free and Semi-Parasitic Copepoda,' by Dr. G. S. Brady, was published by the Ray Society in 1878-1880. That work, which consists of three volumes, marked a second important stage in the study of these minute crustaceans, and was an evidence of the increasing attention their study was receiving. But though several groups of the nonfreeliving species were described in that Monograph, those found parasitic on fishes were expressly omitted. The author in his Introduction states: "The truly parasitic forms-fish-lice, etc.-are excluded as not coming within the scope of my work. They are of themselves sufficient to occupy an independent volume, 
and to afford abundant work to any naturalist whose time and opportunities allow of his taking them in hand "(Vol. I, p. 2). The present Monograph is the result of an endeavour to enumerate and describe the species which Dr. Brady has excluded, and may therefore be regarded as supplementary to that author's work.

The Copepoda recorded by Dr. Baird as parasites on British fishes number thirty-four species; this number is now increased to one hundred and thirteen. Many of the new records are scattered through various publications, and it has been considered by the Council of the Ray Society that, for the convenience of students, these should be brought together and combined with those described by Dr. Baird, and thus made more accessible. This work, which has been intrusted to us, we have endeavoured to carry out, and we hope, while conscious of its imperfections, that it may be found useful and tend to create a still greater interest in the study of these remarkable organisms.

In the preparation of this Monograph we have been indebted for valuable assistance to numerous friends, and to none more so than the Rev. Canon A. M. Norman. Indeed but for his encouragement and assistance it is doubtful if we could have ventured to undertake it. We therefore embrace this opportunity of expressing our gratitude to him, not only for his helpfulness in this special work, but also for kindness shewn to us in many other ways. We are also indebted to Dr. Williamson and Dr. Bowman of the Scientific Staff of the Fishery Board for Scotland for a number of rare and interesting specimens; and to our friend Mr. John Lindsay (of Messrs. Blackwood \& Sons, Edinburgh) for assistance in revising the proofsheets and other useful help. Our grateful acknowledgments are also due to Mr. John Hopkinson, Secretary of the Ray Society, for the great labour and interest he has taken in seeing the work through the 
press. Our obligations to other friends who have assisted us with information or specimens are gratefully acknowledged in the body of the work.

The drawings have, with some few exceptions, all been prepared from recent specimens, examined by ourselves, and wherever possible careful dissections have been made.* There are a few species, however, of which we have been unable to obtain specimens, such for example as Demoleus paradoxa, Lernæocera cyprinacea, Brachiella pastinaca, and perhaps one or two others, figures of which have, with due acknowledgment, been reproduced from published works mentioned in the sequel. In a considerable proportion of the species dealt with in this work the ovisacs are frequently greatly elongated, and we have followed Dr. C. B. Wilson in adopting the term "egg-strings" to describe them. The coloured figures of the parasites represent them as observed by us in the particular specimen illustrated. The colours vary considerably according to the condition of the parasite, the place where it was attached, and the freshness of the host. External parasites lose their colours much more rapidly than those that are found under the operculum or attached to the gills, and it is not always possible to obtain perfectly fresh fish.

\section{THOMAS AND ANDREW SCOTT.}

Aberdeen,

31st March, 1913.

* Note By Thomas Scotr.-The drawings and dissections referred to above are entirely the work of my son Andrew Scott, who has otherwise assisted in the preparation of the Monograph. 



\section{CONTENTS.}

IntRoduction . . . . . . . . 1

Systematic List of the Species. . . . . . 30

Descriptions of the SPECies . . . . . . . 33

Tribe I. CYCLOPOIDA . . . . . 33

Fam. I. ERgasilide $\quad$. . . . . . 33

Tribe II. CALIGOIDA . . . . . 43

Fam. if. Caligider . . . . . . 44

FAM. III. Dichelestimde . . . . . 105

Fam. IV. Philichthyid瓜 . . . . 137

TRIBE III. LERN ÆOIDA $\quad$. . . . 141

FAM. v. LeRn खIDA . . . . . 141

Fam. vi. Chondracanthide . . . 166

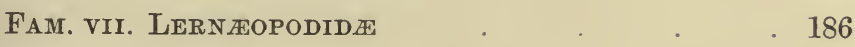

Argulus foliaceus . . . . . . . 227

Tripaphylus musteli (amended description of male) . . 229

List of the Fishes on which Parasitic Copepoda were OBTAINED

Bibliography of Memoirs referred to in the Text . 233 INDEX . . . . . 248

ERrata . . . . . . . . . . 252 



\section{BRITISH PARASITIC COPEPODA.}

\section{INTRODUCTION.}

Parasitic habits are not peculiar to any class of organisms, but are met with in all departments of life, vegetable as well as animal. Nevertheless there ar'e certain groups both of plants and animals whose environment seems to be specially favourable for the adoption of habits of a parasitic or semi-parasitic kind. Such habits seem to prevail to a considerable extent among the Crustacea, and particularly among the so-called lower forms belonging to that class. Many kinds of animals are required to act as hosts for these crustaceans, and curiously enough not a few of them belong to the same class as that to which the parasites themselves belong. Many fishes are also infested by these crustacean parasites. Fishes live in a medium where on every side they are exposed to the attacks of all kinds of parasitic forms, so that very few of the fishes examined by us are found to be entirely free from these organisms.

At a fish-market where quantities of fishes of various kinds are being landed, crustacean parasites may be frequently observed on the skin of the fishes, or found adhering to their fins, their gills, or on the inside of

TOL. I. 
the gill-covers; sometimes they may be found clinging to the roof and sides of the mouth, as well as on the tongue, especially the under side of it, and also in the nasal fossæ. At other times they make excavations in the flesh of the fish, causing sores of a more or less serious nature, and they may even penetrate into the abdominal cavity, as occasionally happens with Lernæan parasites.

The degree of parasitism varies greatly even among: closely allied species. In somes cases the relationship of the crustacean to the fish is decidedly that of a parasite, while in others it would scarcely be accurate to describe the position of the crustacean to the fish as truly parasitic. Sometimes, however, it is more convenient to use the terms "parasite" or "parasitic" in the wider sense to avoid any confusion which might arise by trying to define in each particular case the degree of relationship of the one to the other, and it is in the wider sense that these terms are used here.

The study of the Parasitic Crustacea is in some respects more difficult, if also more interesting, than that of the species which live under normal conditions. Their structure has become more or less altered by reason of their parasitic habits, and the forms which some of them assume are greatly at variance with those of free-living species. The forms of some of these parasites are so abnormal and grotesque that even experienced investigators have been deceived, and have failed to recognize their relationship to the Crustacea, and only by the study of their life-histories have their true affinities been determined.

Among the crustacean parasites of fishes the Copepoda are probably more numerously represented than any other of the crustacean Orders, and what we pro- 
pose in the first volume of the present work is to give descriptions of the various parasitic Copepoda known to occur on British fishes. The second volume will contain the figures.

We have not considered it necessary to enter into a lengthened discussion on the structure and development of the parasitic Copepoda; this has already been done by Dr. Baird and some other writers. Mr. C. B. Wilson, in his various contributions dealing with the North American parasitic Copepods, has described them very fully both in their histological and physiological aspects. Moreover one of the authors of the present volume (A. Scott) has published a Memoir containing detailed accounts of a Lepeophtheirus and a Lernæa, representing two important and diverse types of the parasitic species.*

\section{General Remarks on Development, Etc.}

The following general remarks concerning the development and structure of these organisms are derived chiefly from the works referred to above.

The Copepod parasites of fishes are roughly divided into two groups-viz., those which in the adult stage are free, that is, they can move about, at least to some extent, from one part of the fish to another; while the others are permanently fixed. Lepeophtheirus pectoralis may be taken as representing the first, and Lernæa branchialis the second.

The two groups taken together form a series which exhibits remarkable variation in habits and structure. While there is little to distinguish some of the species at the one end of the series from free-living non-parasitic Copepods, those at the other end exhibit

* Liverpool Marine Biology Committee, Memoir No. VI : 'Lepeophtheirus and Lernæa' (1901). 
forms so abnormal and grotesque that, as already observed, it is difficult without a knowledge of their life-histories to regard them as belonging to the Crustacea.

The young Copepod, no matter how abnormal it may be when adult, begins life as a free-swimming nauplius; it is of an oval form, with a single median eye and three pairs of limbs arranged round the mouth; there are no frontal appendages and no proper mouth-organs.

The young parasite passes through numerous ecdyses and increases in size. The various appendages make their appearance in regular order, and the animal gradually takes on the adult condition. In the case of those parasites which retain their active habits throughout life, the appendages become completely developed when the adult form is assumed. On the other hand, the appendages of the parasites that are more or less permanently attached to their host are comparatively well developed early in life, and then continue in a stationary condition or are gradually suppressed. One finds on carefully dissecting the head of an adult Lernxa from the gills of its host that the four pairs of swimming-feet which were developed at an early period of its life are present, and retain the characters they had during the cyclops stage, although they are not of any use to the animal. The four pairs of feet are buried with the head in the tissues, and if by any means the animal could detach itself from its host, they obviously would not enable it to swim through the water. In some parasites certain appendages used as anchors, such as the antennæ and second maxillipeds, become greatly developed and are conspicuous even to the 
naked eye. In others the cephalic segment becomes highly chitinised, and is frequently expanded into horn-like processes which are buried in the tissues of the host. Certain members of the Caligoida are able to live apart from their hosts and lead a more or less pelagic life in the water for a time, but whether adult females voluntarily detach themselves from healthy and living hosts is doubtful. They appear, however, to leave the host when it dies in an aquarium tank. One rarely finds Lepeophtheirus pectoralis on dead flounders which have been allowed to remain in a tank for a day or two after death, although it was quite certain they were present when the host was alive. We have kept Lepeophtheirus pectoralis alive in vessels of sea-water for periods of six weeks after removal from flounders. Adult males of Caligus rapax are often met with in collections of plankton, but the females are less frequently noticed. The members of the genera Chondracanthus and Clavella sometimes live for a couple of days after being removed from their hosts, but the Lernæa quickly perishes. It is almost certain that, with the exception of a few members of the Caligoida, all the copepod parasites of fishes die soon after the death of their host, even although the body remains in the water. On one occasion we dissected the spiracles of a large grey skate (Raia batis) which had evidently died in the sea and was afterwards washed up partly macerated on the beach. A fullgrown specimen of Charopinus dalmanni was found in one of the spiracles and was in a perfect condition, but there was no sign of life in it.

The sexes are separate, the males as a rule being much smaller than the females. In many cases the males are simply parasites on the females, especially 
those of Chondracanthus, Lerneopoda, and Clavella. The fact that males are found upon egg-bearing females of these genera is due to their power of locomotion having been lost when they reached the adult condition. When once they have settled down on a female and matured they are unable to change their position to any extent. Fertilization of the female is effected early in its life, before the metamorphoses are completed. The resulting embryos pass out from the two oviducts and remain attached to the external apertures either in single or multiserial columns, each being enclosed in a sac, until they hatch. In Chondracanthus zei the columns are very much compressed and resemble miniature oval biscuits. The period of incubation extends over several weeks. The young parasites hatch out as free-swimming nauplii. These undergo metamorphoses, which in some forms, after a particular stage is attained, are retrogressive, finally leading to the adult condition.

The following is a short account of the anatomy of two members of very different families, the Caligoida and the Lernæoida. For fuller details the Memoir published by the Liverpool Marine Biology Committee and the reports by C. B. Wilson on North American Parasitic Copepods should be consulted.

\section{T'ribe Caligoida.}

The species chosen to represent this tribe is Lepeophtheirus pectoralis (Müller). This parasite is sometimes very common on the fins and body of the flounder or "white fluke" (Pleuronertes flesus). It also occurs on other members of the Pleuronectidæ. Although Lepeophtheirus pectoralis does not confine itself to any particular part of the exterior of its host, 
and though adult and immature specimens of both sexes may be found scattered all over the body, mature egg-bearing females are most frequently met with under the pectoral fins. (See Plate A.) It is possible to collect a fairly complete series of stages of development from the one host. The average length of a mature egg-bearing female is one-fifth of an inch, and of a male one-ninth of an inch. The parasites attach themselves to the fish by means of their powerful second maxillipeds assisted by the antennæ, and a decided pull has to be applied before they can be removed. By depressing the edge of the carapace and applying it closely to the skin, the parasite is able to increase its holding power to such an extent that the posterior portion can be torn off from the anterior without detaching it. The anterior portion when thus separated will sometimes remain alive for tiwenty-four hours. It is even capable of swimming about vigorously, but eventually its movements become erratic and finally it dies. Lepeophtheirus pectoralis can be kept alive in sea water for about six weeks after removal from the host. The parasites live for a considerable time after the fish has been caught and removed from the water, if they are not allowed to dry up. Increase of temperature to $16^{\circ} \mathrm{C}$. is fatal to them. Decrease of temperature to even below freezing-point does not appear to incommode them. If the aquaria are kept cool, the sea-water in which the parasites are placed after removal from the host need only be changed at long intervals.

External Appearance and Structure.

The animal is depressed dorso-ventrally and is divided into four parts. The first and usually the 
largest is almost circular in outline. It bears all the appendages with the exception of the fourth and fifth pairs of feet. This part is known as the cephalo-thorax. The second part is very small and represents the fourth thoracic segment of the pelagic Copepoda. It bears the fourth thoracic feet. The third part of the body is of variable size and shape, and is known as the genital segment. Its size. and shape depend largely upon the degree of maturity of the reproductive organs. 'The fourth part is short and narrow. It is only about one-fourth the width of the genital segment. It represents the abdomen of the pelagic Copepoda, and bears at its apex two short papillæ known as the furcal joints or caudal stylets.

Viewed from above, the cephalo-thorax is seen to be slightly convex and divided into four portions by imperfect sutures. The frontal margin is indented. The greatest depth is in the middle line. In the centre of the hollow, situated on the ventral surface, is an ovalshaped opening with a chitinous fringe. This opening is apparently a rudimentary sucker, and is the remains of a median sucker which is greatly developed in the early life of the parasite. This rudimentary sucker can be traced in all the members of the Caligoida. No other suckers are present in the members of the genus Lepeophtheirus. The frontal and lateral margins of the segment are surrounded by a transparent membrane with faint transverse lines. This membrane is simply an extension of the chitinous exoskeleton which covers the whole animal. The edges have frequently a serrated appearance, but this is due to the membrane being damaged. The eyes appear as a reddish spot in the living animal. They are placed on the dorsal surface midway between the anterior and 
posterior margins. When the spot is examined microscopically it is found to consist of two distinct eyes closely approximated and emibedded in a mass of reddish-black pigment. The eyes are wholly under the carapace. Each eye has a simple, spherical, crystalline lens beneath a thin cornea. Behind the lens lies a row of retinal cells of fairly large size and lined internally with a layer of pigment. A chitin division deeply pigmented with red separates the two eyes.

\section{The Appendages.}

There are twelve pairs of appendages, as follows:One pair of antennules, one pair of antennæ, one pair of mandibles, two pairs of maxillæ, two pairs of maxillipeds, and five pairs of feet. The first three pairs of feet only are adapted for swimming. The fifth pair of feet is very small and is attached to the posterolateral margins of the genital segment. A sixth pair of feet is usually present in the male, appearing as small papillæ immediately behind the fifth pair.

The antennules are placed on the frontal margin of the cephalo-thorax and are two-jointed. The basal joint is usually moderately broad and is furnished with a number of plumose setæ. The setæ are well supplied with nerves and evidently act as sensory organs. The other appendages are all on the ventral surface. The first in order are the antennæ. These are two-jointed. The apical joint is a strongly-prehensile claw which is used for holding on to the host. The mandibles are stylet-shaped and are enclosed in the suctorial mouth. The apical joint is flattened and curved. The inner margin is distinctly serrate at the distal end, the serrations being sometimes more or less irregular.

The mandibles of all the copepod parasites of fishes 
with the exception of Chondracanthus are of a somewhat similar type to that of Lepeophtheirus. The first maxillæ are one-jointed and are situated near the lateral margins, slightly posterior to the base of the antennæ. The second maxillæ are also one-jointed and are placed at the sides of the suctorial tube which carries the mouth at its apex. The first maxillipeds consist of two-jointed appendages and are situated just behind the second pair of maxillæ. The apical joint is claw-like and prehensile. The second pair arise midway between the first and the first pair of feet. They are composed of two joints. The basal joint is much inflated, and the apical is in the form of a powerful claw which closes upon the basal joint and provides the animal with a strong grasping appendage. The first three pairs of feet consist of an endopodite and an exopodite attached to a two-jointed protopodite. The endopodite of the first pair is rudimentary and is represented by a minute joint bearing a few setæ. The exopodite is two-jointed. In the second pair both the endopodite and the exopodite are three-jointed. The protopodite of the third pair is greatly developed and forms a prominent lamella. The exopodite and endopodite are very small, the former being composed of two and the latter of three joints. Each of the first three pairs of feet is attached to a sternal plate. The protopodite of the fourth pair of feet is two-jointed and the exopodite is also two-jointed, but there is no trace of an endopodite. A strong chitinous plate with a bifid apex arises from the middle line between the second pair of maxillipeds. This is known as the sternal fork. Its function is not clearly established. It has been suggested that it acts as a crutch to raise the body of the animal from that of the 
host to enable either the mouth-organs or swimming feet to have free play. The sternal fork, however, is not articulated, neither is it flexible.*

The external openings are the mouth, the vulvæ and apertures of the oviducts in the female, the vasa deferentia in the male, and the anus. The mouth is situated on the ventral surface of the cephalo-thorax, and is placed at the apex of a short, conical, movable tube. The vulvæ are situated on each side of the middle line at the posterior end of the genital segment and communicate with the receptacula seminis. They are difficult to see in the adult female, but each has frequently a spermatophore attached which indicates the position. The openings of the oviducts are in the same segment, but nearer the lateral margins and just under the fifth feet. The openings of the vasa deferentia are situated on the postero-lateral margins of the genital segment of the male. The anus is in the middle line at the apex of the abdomen. In addition to these more important openings, there are also apertures of pore-canals and glands on the anterior surface of the basal joint of the protopodites of the second and third pairs of feet, and also on the dorsal surface of the cephalo-thorax and abdomen. The opening in some cases is at the apex of a small papilla, and communicates with a sac in the interior. The function of these glands is uncertain, but it is possible that it is connected with the aeration of the blood. If a little methylene blue solution be added to the sea-water in which the parasites are living, a general staining takes place, but the glands are more deeply stained than the rest of the body.

* Fig. 1, Pl. XIII, shows the general arrangement of the appendages in Lepeophtheirus. 


\section{Colour.}

The colour of the living animals varies with the position in which they live. On the dark side of the fish they are of a deep brown, almost black, colour. On the "white" side and under the fins they are nearly colourless, due to the contraction of the pigment-cells, which appear as brown spots under the microscope. The dark-coloured specimens soon become colourless when exposed to light.

\section{Alimentiary System, E'tc.}

The body-wall consists of (1) chitinous cuticle or exoskeleton, (2) cellular hypodermis, and (3) connective tissue laminæ which line the integument, traverse the body-cavity, and support the alimentary canal and other organs. The only cavity left inside the bodywall is the system of lacunæ in which the colourless blood flows.

The mouth, already described, leads into a short narrow osophagus, lined with a thin chitinous coat which is continuous with the exoskeleton. The œsophagus passes through the anterior part of the nervous system, and in a transverse section of that region appears as a minute pinhole. The stomach lies along the ventral surface and is lageniform in shape. At the anterior end it is produced into a short cæcum, which extends over the posterior end of the œsophagus and terminates by opening into the intestine. The intestine is simply a direct continuation of the stomach and terminates in a short rectum leading into the anus at the apex of the abdomen. tions in the alimentary canal. There are no convolualimentary canal is lined with a thin layer of chitin 
continuous with the exterior. The wall of the stomach and intestines is marked by a series of transverse constrictions, giving it a crenate appearance which is easily seen in the living animal. When the animal is alive an intermittent movement of the alimentary canal is maintained. The action is wave-like. It begins at one end and passes slowly to the other. After continuing in one direction for a time, it reverses and passes along the opposite way. The fluids in the alimentary canal are usually colourless. Sometimes, however, when taken direct from the fish and placed under the microscope, a reddish tint may be observed at the posterior end of the esophagus. Two pairs of digestive glands are connected with the alimentary canal. The first and most important pair is situated in the anterior end of the cephalo-thorax. Each gland consists of three portions, two moderately large masses on the lateral margins just behind the antennules, and a median, smaller one, in front of the base of the mouth. The lateral masses are connected with the median one by a duct. A duct is given off by the median portion and passes posteriorly along the outside of the œsophagus. It enters the cæcum at the anterior end of the stomach. When the parasite is first removed from the host the glands are usually of a dark brown colour, but they soon become bleached. The product of the glands is a pale yellow fluid. The second pair of glands is much smaller than the first, and is situated close to the median line between the first and second pairs of feet. 'The glands are of a brown colour and shaped like a comma. A minute duct from each gland passes downward and then forward along the stomach, which it enters near the posterior end. 


\section{Crrculatory System.}

There is no heart in Lepeophtheirus, nor are there any proper blood-vessels. The circulation is wholly lacunar. The blood-streams simply pass through the spaces left among the internal organs and between the connective-tissue bands of the body-wall. The streams appear to have certain definite courses, but they are not uniform, continuous currents. The fluid progresses by successive jerks, due to the peristaltic movements of the alimentary canal. The blood is a clear fluid containing numerous colourless corpuscles which vary in size and shape. The corpuscles are able to accommodate themselves to the diameter of the spaces through which they pass. There are no independent organs of respiration, unless the pore-canals and glands in the basal joint of the protopodite of the second and third pairs of feet act as such. Hartog* and others have suggested that the blood is probably aerated from the sea-water contained in the alimentary canal by the method of "anal respiration." Further precise observations are, however, required to substantiate this hypothesis, as the method is so entirely different from that in the higher Crustacea.

\section{Muscular System.}

The muscular system is a very complex one, as shown by the illustrations of the dorsal and ventral surfaces on Plate XIII. The members of the Caligoida as a general rule are so very transparent, however, that the investigation of the musculature can be carried out with very little effort. An excellent description of the muscular system is given by * "The morphology of Cyclops and the relations of the Copepoda," "Trans. Linn. Soc. Lond.' (2), vol. v, pt. 1, pp. 1-46, 1888. 
C. B. Wilson in his work on "North American Parasitic Copepods belonging to the Family Caligidæ," Part 1.*

\section{Nervous System.}

The nervous system of Caligus and Lepeoplitheirus, and probably also of the other members of the Caligoida, appears to be very similar. It is composed of two central ganglia and the paired nerves which arise from them. One ganglion, the supra-œsophageal, lies above the œsophagus, and the other, the sub-œsophageal, immediately below it. The ganglia are practically fused together by the wide commissures which join them. A very narrow opening is left in the centre for the passage of the œsophagus. These are the only ganglia, and they supply the various parts of the body with nerves. The supra-œesophageal ganglion is about half the size of the sub-œsophageal. It is produced on its dorsal surface into an optic lobe from which arises a distinct pair of optic nerves. Horizontal sections of the optic lobe show that the roots of these nerves cross each other, and each optic nerve, therefore, is supplied by fibres from both sides of the brain. The only other nerves that have their origin in the supra-œsophageal ganglion are those which supply the antennules and the antennæ. The nerves of the antennules divide into a number of branches after they enter these appendages, and every seta on the surface of the basal joint and apex of the second branch is supplied with fibres. It is evident that they are important sensory organs. The subœsophageal ganglion is heart-shaped, and fully twice the size of the supra-œsophageal. It supplies the nerves to the remainder of the appendages. The * 'Proc. U. S. National Museum,' vol. xxviii, 1905. 
frontal and lateral margins give off seven pairs of nerves. Three other pairs arise from the posterior end and form a sort of spinal cord. There are thirteen pairs of nerves altogether, as shown in Plate XV, fig. 9. Each nerve, after leaving the main trunk, sends out numerous branches which pass to the various muscles controlling the appendages enervated by that nerve. There is considerable difficulty in tracing the endings of the branches when they pass amongst the muscles.

\section{REPRODUC'ION.}

The reproductive organs are paired, and as already stated the sexes are distinct. In the mature female the ovaries appear as comparatively large kidneyshaped organs on each side of the anterior end of the stomach. An oviduct arises near the anterior end of the ventral surface and passes posteriorly as a narrow tube until it enters the genital segment. It then expands rapidly and becomes convoluted, finally passing out to the postero-lateral margins of the segment, where it opens to the exterior just under the fifth feet. Communicating with the oviduct near its extremity is a short semi-transparent cement-gland which secretes the enclosing membrane of the orisac. The vulvæ are situated near the middle line close to the junction of the genital segment with the abdomen. The vulva appears to be a simple opening leading into the vagina which expands into a receptaculum seminis. This is an elongated sac passing from the median line to the oviduct, which it enters alongside the duct of the cement-gland.

The sexual organs of the male are very similar in position and arrangement to those of the female. 
They consist of a pair of testes, a long vas deferens leading posteriorly from them, and a pair of spermatophore sacs in the genital segment. The testes are oval bodies situated in a corresponding position to the ovaries in the female. The spermatophore is an oval body of a pale yellow colour filled with sperms. It is expelled from an opening near the posterior end of the genital segment. A short cement-gland is situated in the segment and is furnished with a duct which is connected with the anterior end of the sac.

The female is fertilized early in life by the male attaching spermatophores to the vulvæ. The contents of these bodies appear to suffice for the fertilization of all the eggs which the female produces during its life. The genital segment of an unfertilized female is very small. It is only about one-fifth the size it attains in the mature condition. The eggs are fertilized from the store of sperms as they leave the oviduct, and are then enclosed in a thin chitinous tube which gradually lengthens as the eggs are expelled. This tube is the ovisac, and the eggs are arranged in a single column sometimes exceeding the length of the animal. The whole of the embryos in the tube practically hatch at once when the development is completed. The embryos hatch as nauplii about $0.46 \mathrm{~mm}$. in length. The nauplii are free-swimmers for a time and then settle down as cyclops forms upon their host. As soon as the cyclops form settles it develops a thin chitinous filament from a median gland in the anterior end of the cephalo-thorax. The filament is inserted in the tissues of the lost and the young parasite becomes firmly anchored. A median sucker which assists in the attachment is also developed at the same time. The genus Chalimus, described by Burmeister in 1831, was 
shown by Hesse and others to be only the cyclops stage of the Caligoida. The cyclops form grows, and the various appendages make their appearance in regular order. When the appendages are developed the filament separates at its junction with the frontal margin, and the parasite is free to move about over its host or to seek a new one. A notch is left in the frontal margin when the filament separates, and continues all through the adult life. The male, at the conclusion of its cyclops stage, is practically fully developed. The female remains in an immature condition until it is fertilized and the ova begin to pass down the oviducts. The genital segment then increases in size to its normal adult condition.

\section{Tribe Lernetoida.}

The typical member of this tribe is Lernæa branchialis Linn. It presents one of the most marked examples of retrograde development which is to be found in the whole group of parasitic Copepoda. It is difficult to believe at a first glance that the parasite is a crustacean and that it is related to Lepeophtheirus. There is great excuse for the difficulty experienced by the earlier zoologists in deciding the true position of the members of this family in the animal kingdom. Nothing was then known about their life-history, and it is not surprising that Linnæus included Lernæa amongst his Vermes.

The adult female is found on the gills of various Gadoids, such as cod, haddock, and whiting. (See Plate A.) Immature (cyclops stage) males, and females with adult males attached, are to be found on the apex of the gill-filaments of flounders and plaice, sometimes in large numbers. The adult female is 
securely attached to its host by strong branched horns which are buried in the tissues of the gill-arches. In many cases the head will be found to have actually penetrated the ventral aorta. The specimens can only be removed from the host by careful dissection. Any attempt to remove them by force results in the head being left in the tissues. The parasite, when once fixed, remains in the same position throughout life. When it dies the softer parts decay, but the head remains embedded in the tissues of the host. The heads of dead parasites are frequently met with when dissecting-out living specimens.

The adult female is cylindrical and is a little over an inch in length. It is unsegmented, but can be roughly divided into three parts - a globular head with anchorlike processes, a narrow neck, and a much swollen posterior part. The globular head corresponds to the anterior region of the cephalo-thorax in Lepeophtheirus. It is furnished with three more or less branched horns which are outgrowths from the cephalo-thorax. The head is slightly curved downwards and terminates in a conical apex. The anterior portion of the neck represents the remainder of the cephalo-thorax and the fourth thoracic segment. The remainder of the neck and the greater part of the swollen mass behind correspond to the genital segment of Lepeophtheirus. The abdomen is represented by the terminal portion of the swollen part, which gradually tapers to a blunt end. The whole of the swollen part is bent into the form of the letter $\mathbf{S}$. The neck is marked by fine transverse lines.

The appendages are rudimentary, the greater number being entirely absent. The appendages present are a pair of maxillipeds immediately under the mouth and 
four pairs of feet at the anterior end of the narrow neck. The feet are exactly as they exist in the fully developed cyclops stage, both in size and structure. The protopodite is two-jointed. The exopodite of the whole four pairs is two-jointed. The endopodite of the first two pairs is also two-jointed. The third and fourth pairs of feet have no endopodite.

The external openings are the mouth placed at the apex of the head, the openings of the oviducts on the ventral aspect of the $\mathbf{S}$-shaped region, and the anus at the blunt apex of the abdomen.

The colour of the living animal is a dark red, due to the contained blood. When removed from the fish and placed in sea-water the colour disappears. Specimens of Lernæa removed from their host and placed in sea-water do not appear to live longer than twelve hours. The parasites are simply inert sacs quite incapable of movement. Occasionally they are covered with colonies of hydroids which may entirely obscure them. The exoskeleton consists of chitinous cuticle moderately thin and soft in the swollen part, but thick and hard on the neck and head.

The mouth of the adult opens directly into the alimentary canal. The œsophagus and true stomach have entirely disappeared during the metamorphoses of the cephalo-thorax. A peristaltic movement of the intestine similar to that of Lepeophtheirus can be seen in the living animal. There are no indications of digestive glands, and it is probable that the digestion is intracellular.

There is no heart in adult Lernxa and no movement of fluids that would indicate a blood-circulation. The animal is probably dependent on the blood sucked from the host for the oxygen necessary to maintain 
life. It is possible that the early death after removal from the host is due to the inability to take up oxygen from the water.

The muscular system is represented by a network of fibres between the integument and the alimentary canal.

There does not appear to be any nervous system in the adult.

The reproductive organs of Lernæa, like those of Lepeophtheirus, are bilaterally symmetrical, but during the metamorphoses of the female the ovaries undergo a great change of position. They are displaced from the cephalo-thorax and pass into the genital segment, where they occupy a narrow region at the apex of the deep indentation. The two ovaries are practically fused together. The oviducts arise from their anterior ends, pass across the segment to its ventral surface, and then course along each side of the median line to the external openings. The cement-glands are nearly of the same length and breadth as the oviducts and lie underneath them. The posterior end communicates with the oviduct just inside the opening to the exterior. The ovisacs consist of long slender convoluted tubes which may reach the length of eight inches when straightened out. The eggs are arranged in a single column. The female is fertilized shortly before the completion of the cyclops stage. It is probable that the sperms pass up the oviduct and fertilize the eggs very soon afterwards, as no trace of a receptaculum seminis can be made out in the adult.

The young Lernæa hatches as a nauplius with three pairs of appendages similar to those of the Lepeophtheirus nauplii. It leads a short pelagic life and then settles on the gill-filaments of the flounder and plaice and occasionally other fishes. It attaches itself 
to the filament by a thin broad chitinous plate and by the claw-like antennæ. The young parasite assumes the cyclops form and continues its progressive development. The various appendages and internal organs make their appearance. The male reaches maturity without altering from the cyclops form, and undergoes no further change. A considerable lengthening of the female genital segment accompanies the development of the various appendages. Fertilization takes place, and the young female severs its connection with the gill-filament. It leads a pelagic life for a time, and is occasionally found in surface-plankton. The males, unless accidentally separated, remain on the gill-filaments after the females have gone.

The cyclops form of Lernæa appears to cause considerable damage to the gills of its temporary host. The whole of the apex of the gill-ray assumes a tumid appearance, and a considerable number of the gillfilaments disappear from both sides. (See Plate A.*) When the fertilized female leaves the gills of the flounder or plaice the appendages and internal organs have practically completed their development. A pair of eyes similar in structure to that of adult Lepeophtheirus is present on the anterior region of the cephalo-thorax. The appendages are represented by one pair of four-jointed antennules, one pair of clawlike antennæ, one pair of mandibles which are not enclosed in the mouth-tube, one pair of maxillæ, two pairs of maxillipeds, and five pairs of feet. The body is divided into five distinct segments-the cephalothorax, three thoracic segments, and one terminal segment which represents the genital segment and abdomen. The whole of the terminal segment is

* See also Plate XLII, fig. 8. 
marked by fine transverse lines. The colour of the animal varies from dark violet to light red. The alimentary canal is similar in structure to that of the adult Iepeophtheirus. A large digestive gland occupies each side of the cephalo-thorax. The nervous system of the Lernæan cyclops is practically similar to that of the adult Lepeophtheirus. The ovaries occupy a normal position.

At the conclusion of its pelagic life the Lernæan cyclops fixes itself to the gills of a fish, and the retrogressive metamorphoses commence. The parasite buries its head in the tissues of the host and then develops three horns. The horns are simple at first, but by gradual division they acquire the adult type. The genital segment elongates very considerably. The eyes, antennules, antennæ, mandibles, maxillæ, and one pair of maxillipeds completely disappear. One pair of maxillipeds persists all through life, and is represented in the adult by a pair of small hooks placed under the mouth.

The next phase, represented on Plate XLII, shows that the development of the horns, the disappearance of the various appendages, and the great lengthening of the genital segment are followed by a looping of the posterior region at that segment. This loop gradually expands, and finally takes on the adult condition.

\section{The Food of the Parasties.}

There appears to be considerable doubt regarding the precise food of the Copepod Parasites of Fishes. Some authors conclude that, because no red colour can be seen in the alimentary canal, such families as the Caligoida feed entirely upon the mucus of the host's body. It has been suggested, therefore, that Lepeo- 
phtheirus and allied forms are not parasites in the strict sense of the term, and may not be hurtful to their hosts. There is little doubt about the food of Lernæa. It is generally found in a position that is plentifully supplied with blood. Its mouth is buried out of the reach of mucus, and is often in direct communication with the main blood-stream entering the gills to be purified. Caligoids from the gill-chamber and the mouth seldom show any trace of red colour. Degenerate forms such as Clavella and Chondracanthus, although actually living amongst the gill-filaments, are usually of a pale yellow colour, with occasionally a grey central streak indicating the alimentary canal. Lernanthropus kroyeri, which lives amongst the gillfilaments of Lubrax lupus, is nearly always of a deep brownish-red colour. It is said that mucus at the best is a poor food, but Lepeophtheirus can live for upwards of six weeks in filtered sea-ivater without visible food of any kind. Mucus may not be a very sustaining form of nourishment, but as the Caligoids apparently do not require much food they may be able to obtain sufficient from the mucus. C. B. Wilson says: "There is more mucus on the scales than anywhere else; why should they choose the fins or inside of the operculum?" The fins and gill-chamber afford a certain amount of protection to the parasites, and it is just as likely that they choose these places for shelter as for food. It has to be remembered, however, that the difference between the Caligoida and the obviously blood-sucking Lernæa is very great. The Caligoids are provided with large digestive glands which are entirely absent in the adult female Lernæa. When one finds blood in the alimentary canal of a parasite which has no digestive glands, and none in those which are provided with 
such organs, it may reasonably be concluded that the character of the food will be rapidly altered. The fluid from the glands meets the food immediately it enters the stomach of the Caligoids and acts upon it at once. If blood be the food, the red colour may be destroyed, and give rise to the impression that Caligoids are not blood-suckers.

Nothing appears to be known regarding the internal organs of the Copepod Parasites of Fishes with the exception of the Caligoida and Lernæa. When the anatomy of all the families has been investigated the food question may be settled. One or two parasites on a fish may not be hurtful, but when the numbers increase they probably have an irritating effect, and finally, when they remain in one position for some time, the skin and tissues become badly lacerated, giving rise to tumours. The Medesicaste, which lives on the gills of various species of gurnards, occasionally has its head buried in a tumour-like swelling, but we have been unable to determine whether the tumour existed previous to the attachment of the parasite or was entirely due to the congestion of the blood-vessels caused by its attack. G. H. Drew, in a paper entitled "Some cases of new growths in Fish" (Journ. Mar. Biol. Assoc., N. s., vol. ix, No. 3, June 1912), describes this tumour-like swelling in the gurnard as a case of hæmangiomata, and regards it as probable that the parasite attacked the tumour after it had developed, but we have never come across the tumour without the parasite, or the remains of it, being present. It is quite as likely, therefore, that the hæmangiomata of the gurnard described by Drew is caused by the parasite. (See also our remarks on Iiernæa, p. 22.) 


\section{SYSTEMATIC ARRANGEMENT.}

In this account of the Copepoda found parasitic on British fishes, the arrangement outlined by Professor G. O. Sars in the introduction to vol. iv of his great work on the 'Crustacea of Norway' has, so far as it concerns these parasitic species, been followed by us.

Professor Sars arranges the Copepoda into seven divisions or tribes, three of which are represented below-viz., the Cyclopoida, the Caligoida, and the Lernæoida. The Cyclopoida show considerable variation in regard to their habits and manner of life; some are entirely free-living (as Cyclops), others are associated with different organisms either as commensals or messmates, their commensalism tending in some cases in the adult stage towards a more or less true parasitic life. Several species belonging to this tribe are associated with fishes.

The Caligoida, which are almost all parasitic on fishes, also exhibit considerable differences in their habits, but although none of them can be accurately described as free-living in the adult stage, some species, such as Caligus rapax, possess considerable freedom of movement, and have, in consequence, a tolerably wide distribution. In the majority of cases, however, the Caligoida, though not usually permanently fixed to their host, are limited in their movements, and do not apparently, to any extent, migrate from one fish to another; and not only are they more or less confined to particular fishes but sometimes also to particular parts of the fish, hence such names as Caligus zei and Lepeophtheirus pectoralis. In the first case the parasite is usually found only on the dory (Zeus faber), while in the second it occurs chiefly on the pectoral fins of flat fishes, such as plaice, flounders, and dabs.

The Lernæoida differ from the other two tribes or divisions by the females in the adult stage being all 
more or less permanently fixed to their host. This group of parasites was arranged by M. Edwards into three families - viz., the Chondracanthiens, the Lernéopodiens, and the Lernéocériens. The Chondracanthiens "are fixed by the aid of stout foot-jaws armed with strong hooks." The Lernéopodiens have the second maxillipeds modified, and furnished, at their extremity, with a chitinous horn-coloured process, which, penetrating the gills, gill-covers, or some other part of the fish, forms a permanent attachment to it, while the head of the parasite is free and apparently possesses to a small extent a certain freedom of movement. In this family the male is very small and is not attached to the fish, but is usually found adhering to the body of the female, two or three males being sometimes found on the same female. The third family of M. Edwards, the Lernéocériens, are fixed to their host by having the head, sometimes with its appendages, buried in its tissues. This arrangement of Milne Edwards, slightly modified, was adopted by Dr. Baird in his 'British Entomostraca,' and is to some extent still adhered to.

Various attempts have been made to frame a classification of the Copepoda which would include the parasitic and semi-parasitic forms, but, with the exception of that of Professor G. O. Sars, they have proved more or less unsatisfactory, and therefore, as already stated, we have, as regards these parasitic species, adopted the division proposed by Sars. Referring to the various attempts at classification, C. B. Wilson, in a recent article on the subject, remarks: "It requires about as thorough a knowledge of the Copepoda to select intelligently from these various schemes, backed as they are by competent authority, as it would to construct an original scheme. Indeed most authors have apparently found the latter the easier, since each has propounded a scheme of his own." *

* "The Classification of the Copepods," by C. B. Wilson, in "Zool. Anzeiger,' vol. $x x x \nabla$, No. 20, 26th April, 1910, p. 611. 
Dr. Bassett-Smith in his excellent paper on "Parasitic Copepoda found on Fishes," published in 1899,* follows, with some slight modifications, the classification proposed by Gerstaecker in Bronn's 'Tierreich,' 1881, and as Sars' main divisions fit in fairly well with this arrangement it has been retained here.

\section{The Cyclopoida.}

The Cyclopoida are represented among the Copepoda parasitic on British fishes by a single family, the Ergasilidæ, which comprises the three genera Ergasilus, Bomolochus, and Thersitina.

\section{The Caligoida.}

The Caligoida are represented by many genera and species ; they are arranged under three families-viz., the Caligidæ, the Dichelestiidæ, and the Philichthyidæ. The Caligidæ have been divided into the following subfamilies: the Caliginæ, Trebinæ, Euryphorinæ, Pandarinæ, and Cecropinæ; but with the exception of the Caliginæ, which comprise Caligus, Lepeophtheirus, and one or two other genera, these subdivisions are each represented by only a small number of species, and it has, therefore, not been considered necessary to adopt these minor divisions here.

\section{The Lernæoida.}

The Lernæoida also comprise a considerable number of genera and species, and these, like the Caligoida, are arranged under three families-viz., the Lernæidæ, the Chondracanthidæ, and the Lernæopodidæ. These represent three tolerably distinct types, and exhibit in the adult female a more or less retrograde development, producing in many cases results, in regard to

* "A Systematic Description of Parasitic Copepoda found on Fishes, with an Enumeration of the Known Species," in 'Proc. Zool. Soc. London,' 18th April, 1899. 
their form and structure, of a remarkable kind, as indicated in the life-history of Lernæa already referred to. In the family Lernæidæ the body of the adult female is greatly distorted, and the head is buried deeply in the tissues of the host; on the other hand, the mature male, which, as shown in Plate XLII, fig. 5, closely resembles the young female before it has begun to assume that abnormal development characteristic of the adult stage, does not, so far as known, undergo any further change, but continues during its short life to retain its normal structure and form. The Chondracanthidæ differ from the other two families by the manner of their fixation, and also by the peculiar form of the mandibles, which are unlike those of any of the other parasitic groups described here. The Lernæopodidæ are also distinguished by their mode of fixation, as shown elsewhere.

The Linnæan species Lernæa asellina, which was ascribed by Blainville and Baird to Lernentoma, and by Nordmann and others to Chondracanthus, was removed to a new genus, Oralien, by Bassett-Smith, on account of some peculiar structural differences. But while appreciating this, and after carefully comparing the characters of Oralien with those of the older genus Medesicaste Kröyer, we are inclined to think that the difference between them is scarcely of sufficient importance for the establishment of a new genus-a conclusion previously come to by Brian.* We have therefore transferred this Linnæan species to Kröyer's genus Medesicaste. Moreover, as Sphyyrion appears to be a true Lernæan rather than a Chondracanthian genus, with which family it is sometimes associated, it has been transferred by us to the family Lernæidæ.

* 'Copepodi parassiti dei Pesci d’Italia,' p. 94. 


\section{SYSTEMATIC LIS'I \\ OF THE SPECIES DESCRIBED IN THIS VOLUME.}

\section{Order COPEPODA.}

Tribe I. Cyclopoida G. O. Sars.

Family I. ERGASILID压.

1. ERgasilus Nordmann.

1. nanus Claus.

2. Bomolochus Nordmann.

1. soler Claus.
2. onosi T. Scott.

3. zeugopteri T. Scott.

3. Thersitina Norman.

1. gasterostei Pagenstecher.

Tribe II. Caligoida G. O. Sars.

Family II. CALIGID无.

4. Caligus O. F. Müller.

1. curtus O. F. Müller.

2. minimus Otto.

3. rapax M. Edwards.

4. centrodonti Baird.

5. gurnardi Kröyer.

6. labracis T. Scott.

7. zei Norman.

8. brevicaudatus A. Scott.

9. pelamydis Kröyer.

10. diaphanus Nordmann.

5. Pseudocaligus A. Scott.

1. brevipedes Bassett-Smith.

6. Sciznophilus P. J. van

Beneden.

1. tenuis P. J. van Beneden.

7. Lepeophtheirus Nordmann.

1. pectoralis O. F. Müller.

2. nordmanni M. Edwards.

3. hippoglossi Kröyer.

4. thomsoni Baird.

[obscurus Bassett-Smith.]

5. salmoris Kröyer.

6. pollachii Bassett-Smith.

7. sturionis Kröyer.

8. LÜtKenia Claus.

1. asterodermi Claus.
[Noga us Leach.

1. ambiguus T. Scott.]

9. Demoleus Heller.

1. paradoxus Otto.

10. Trebius Kröyer.

1. caudatus Kröyer.

11. Elytrophora Gerstaecker. 1. brachyptera Gerstaecker.

12. Dinemoura Latreille.

1. producta O. F. Müller.

13. Есhthrogaleus Steenstrup \& Lütken.

1. coleoptratus Guerin-Men-

2. lütkeni Norman. neville.

14. Phyllothreus Norman.

1. cornutus M. Edwards.

15. Pandarus Leach.

1. bicolor Leach.

16. Cecrops Leach.

1. latreillii Leach.

17. Orthagoriscicola Poche.

1. muricata Kröyer.

18. Philorthragoriscus Horst.

1. serratus Kröyer. 
Family III. DICHELESTIID A.

19. Dichelestium Hermann.

1. oblongum Abildgaard.

20. Anтноosoma Leach.

1. crassum Abildgaard.

21. Lernanthropus Blainville.

1. kröyeri P. J. van Beneden.

22. Hatschekia Poche.

1. hippoglossi Kröyer.

2. mulli P. J. van Beneden.

3. labracis P. J. van Beneden.

4. cluthæ T. Scott.

5. cornigera T. Scott.

6. pygmæa T. Scott.
23. Kroyeria P. J. van Beneden.

1. lineata P. J.van Beneden.

24. Congericola P. J. van

Beneden.

1. pallida P. J. van Beneden.

25. Eudactylina P. J. van

Beneden.

1. acuta P. J. van Beneden.

2. acanthii $\mathrm{A}$. Scott.

3. similis T. Scott.

4. minuta T. Scott.

5. insolens T. \& A. Scott.

Family Iv. PHILICHTHYID A.

26. Рнiцichthys Steenstrup.

1. xiphiæ Steenstrup.

Tribe III. Lernæoida G. O. Sars.

Family v. LERN ÆID死.

27. LERNEA Linnæus.

1. branchialis Linnæus.

2. lusci Bassett-Smith.

3. minuta T. Scott.

4. lumpi T. Scott.

28. НжмоваPнеS Steenstrup \&

Lütken.

1. cyclopterinus O. Fabricius.

29. H五

1. ambiguus T. Scott.

Scott.

30. Pennella Oken.

1. orthagorisci E. P. Wright.
31. LERNAOCERA Blainville.

1. cyprinacea Linnæus.

32. LeRn menicus Lesueur.

1. sprattæ Sowerby.

2. encrasicola Turton.

33. Trypaphylus Richiardi.

1. musteli P. J. van Beneden.

34. Rebelula Poche.

1. edwardsi Kölliker.

35. Sphyrion Cuvier.

1. lumpi Kröyer.

\section{Family vi. CHONDRACANTHID}

36. Chondracanthus De la

$$
\text { Roche. }
$$

1. cornutus O. F. Müller.

2. annulatus Olsson.

3. solex Kröyer.

4. fluræ Kröyer.

5. depressus T. Scott.

6. limandix Kröyer.
7. clavatus Bassett-Smith.

8. nodosus O. F. Müller.

9. zei De la Roche.

10. lophii Johnston.

11. merluccii Holten.

12. ornatus T. Scott.

37. Medesicaste Kröyer.

1. asellinum Linnæus. 
Family vII. LERN EOPODID瓜.

38. Thysanote Kröyer.

1. impudica Nordmann.

39. Charopinus Kröyer.

1. dalmanni Retzius.

2. dubius T. Scott.

3. ramosus Kröyer.

40. ACHTheres Nordmann.

1. percarum Nordmann.

41. LERn eopoda Blainville.

1. elongata Grant.

2. galei Kröyer.

3. cluthæ T. Scott.

4. salmonea Linnæus.

5. bidiscalis de Visme Kane.

6. similis T. \& A. Scott.

7. lampri T. \& A. Scott.

42. Brachiella Cuvier.

1. thynni Cuvier.

2. rostrata Kröyer.
3. insidiosa Heller.

4. merluccii Bassett-Smith.

5. triglæ Claus.

6. ovalis Kröyer.

7. bispinosa Nordmann.

8. pastinaca P.J.van Beneden.

9. parkeri G. M. Thomson.

43. Clavella Oken.

1. uncinata O. F. Müller.

2. rugosa Kröyer.

3. dubia T. \& A. Scott.

4. emarginata Kröyer.

5. scombri Kurz.

6. brevicolis M. Edwards.

7. stellata Kröyer.

8. parudoxa P.J.van Beneden.

9. quadrata Bassett-Smith.

10. canthari Heller.

11. alata Brian.

12. lophii M. Edwards. 


\section{CLASS CRUSTACEA.}

\section{SUB-CLASS ENTOMOSTRACA.}

Order COPEPODA.

\section{Tribe I. CYCLOPOIDA G. O. Sars.}

Cephalothorax ovate and usually more robust than the abdomen. Antennules slender and elongated or tolerably short and stout; those of the male alike on both sides, sometimes modified for grasping.

Antennæ unbranched, or the outer branch rudimentary; usually feebly armed, but sometimes stout or elongated and provided with strong terminal claws. Maxillipeds usually less developed than in the Calanoida, but the second pair sometimes strongly uncinate.

First four pairs of swimming legs as in the Calanoida; fifth pair rudimentary, alike in both sexes, usually one- but sometimes two-jointed, rarely with more than two joints. Egg-strings two.

The Cyclopoida found on British fishes all belong to the one family Ergasilidæ, and to the three genera Ergasilus, Bomolochus, and Thersitina. 'The species comprised within these three genera are associated with fishes of various kinds. They cannot all be accurately described as parasites, some of them, such as Bomolochus solex, should rather be regarded as commensals or messmates; they appear to be able, within certain limits, to move about with considerable freedom. Their food appears for the most part to consist of the mucus exuded by the fish, and it is doubtful if they would long survive if removed from their host.

\section{Family i. Ergasilide.}

Body more or less cyclopoid in form. First segment usually large, sometimes subglobose in the female. Antennules composed of five to seven joints. Antennæ

VOL. I. 
two- or three-jointed, more or less prehensile, and usually armed with terminal claws. Mandibles small. Maxillæ rudimentary. First maxillipeds small and of a simple structure. Second maxillipeds well developed and provided with strong terminal claws. First four pairs of thoracic legs biramose; both rami of the first. three pairs composed of three articulations, but in the fourth pair, while the inner ramus is three-jointed, as in the other three pairs, the outer may consist either of three joints or only of two. Fifth pair small, onebranched, uniarticulate or rudimentary. Egg-strings: two.

\section{Genus 1. ERGASILUS Nordmann, 1832.}

Somewhat like Cyclops in general appearance. Cephalothorax elongated, segments five, the first segment large.

Antennules composed of five or six joints. Antennæ elongated and composed of three joints, terminal claws large, and forming powerful grasping organs. First four pairs of thoracic legs biramose; both rami of the first three pairs three-jointed; fourth pair with the inner ramus three- and the outer two-jointed. Fifth pair small or rudimentary. Egg-strings two.

1. Ergasilus nanus P. J. van Beneden.

(Plate I, fig. 1; Plate II, figs. 1-5; Plate XLVIII, fig. 17.)

1870. Ergasılıs nanus P. J. van Beneden. (16) Les Poissons des côtes de Belgique, leurs parasites et leurs commensaux, p. 27 , pl. i, fig. 6 (recorded and figured but not described in this work).

1901. Ergasilus nanus T. Scott. (113) p. 122, pl. vii, figs. 1-8.

Female.-Body somewhat expanded anteriorly, posterior extremity attenuated. Cephalic segment large, and if viewed from above, somewhat pear-shaped in outline ; the widest part, which is near the anterior end of the segment, equal to fully half its length, and a shallow 
but obvious constriction occurs near its middle. The remaining thoracic and the abdominal segments small.

Antennules short, apparently only five-jointed, and sparingly setiferous; the first joint about twice the length of the second, the fourth rather smaller than any of the others. Antennæ tolerably slender and greatly elongated, composed of three joints, and furnished with moderately strong and curved terminal claws. Mouthappendages apparently more or less rudimentary or obsolete.

The first four pairs of thoracic legs all biramose and well developed; the first three pairs with both the inner and outer rami three-jointed, but in the fourth pair while the inner ramus is three-, the outer is only two-jointed, the first joint being about twice as long as the end one. The fifth pair small, and consisting each of a single one-jointed branch which is about three times longer than broad, with the lateral margins subparallel, and the distal end truncated and bearing two or three moderately long apical setæ. Caudal rami short. Egg-strings two, large, more than half the length of the animal and containing numerous ova. Length, exclusive of egg-strings, $1.2 \mathrm{~mm}$.

Habitat.-Parasitic on the gills of the grey mullet, Mugil chelo (Cuvier). Bay of Nigg, Aberdeen, in July, 1900 ('I'. Scott). Swan Pool, Falmouth (A. M. Nor'mau, 1884).

This appears to be a rare species; though we have examined several specimens of the grey mullet, we have only once observed it. Another species, E. sieboldii, found parasitic on carp, pike, and some other fresh-water fishes, appears to have a wide distribution on the Continent and may yet be obtained in British waters.

We have not seen the male of Ergasilus nanus, nor have we seen any published record of its occurrence; the male of $E$. sieboldii, on the other hand, appear's to be the form which has been most frequently met with. 'I'hough several other. species of Er:/asilus are recorded, E. nanus is apparently the only British representative of the genus. 


\section{Genus 2. BOMOLOCHUS Nordmann, 1832.}

Body elongated, subpyriform, and not unlike a Cyclops in general appearance. Antennules tolerably short and composed of about seven joints. Antennæ small, three-jointed. Mandibles small, simple, and furnished with unequal tooth-like processes. Maxillæ somewhat rudimentary. First maxillipeds small and. two-jointed, the end joint attenuated, and provided. with a few marginal denticles and also with a moderately stout marginal plumose seta which reaches to about the apex of the joint. Second maxillipeds large, composed of two joints, and armed with a terminal claw, which is recurved in the female but not in the male. Swimming-feet all biramose and with both rami three-jointed; the joints of the first pair lamelliform, and furnished with spathulate and denselyplumose setæ. Fifth pair of feet small and consisting of a single biarticulated branch.

The male does not differ greatly from the female, except in the structure and armature of the second maxillipeds.

\section{Bomolochus soleæ Claus.}

(Plate I, fig. 3 ; Plate II, figs. 6-9 ; Plate III, figs. 1-4.)

1864. Bomolochus solex Claus. (33) Zeitschr. f. wiss. Zool., vol. xir, p. 374 , pl. xxxv.

1893. Bomolochus soleæ T. Scott. (111a) Elerenth Annual Report Fisher'y Board for Scotland, pt. iii, p. 212, pl. v.

1902. Bomolochus soler idem. (114) p. 288, pl. xiii, figs. 13-18.

1906. Bomolochus soleæ A. Brian. (21) Copepodi Parassiti dei Pesci d'Italia, p. 31.

1909. Bomolochus soleæ May E. Bainbridge. (3) Trans. Limn. Soc., ser. 2 (zoology), vol. xi, pt. 3, p. 45, pl. viii.

Female.-Cephalic segment short, considerably expanded, widest in the middle, forehead flattened, sides rounded, length equal to rather more than half the width; each of the two thoracic segments which follow are about equal to the length of the cephalic segment, 
but each segment is narrower than that which precedes it; the other thoracic segments small, and partly concealed in dorsal view. Abdominal segments also small.

Antennules moderately short and stout, composed of seven joints, and furnished with long plumose setæ; the joints subequal in length but the fourth rather longer than either the third or the fifth. Antennæ three-jointed, middle joint short, end joint provided with three pectinated, setiferous appendages and a few apical setæ. Mandibles small, but moderately stout, and armed with two small, oval, terminal plates serrated on the edges. First maxillipeds small, each with a stout, setiferous, terminal spine, from the side of which springs a minute accessory spinule. Second maxillipeds having the basai part considerably dilated, but the distal portion slender, curved, and claw-like. The first four pairs of thoracic legs with both the inner and outer ramus three-jointed; in the first pair both rami broadly lamelliform, somewhat distorted, and furnished with densely plumose setæ, the middle joint rather shorter than the first or third. The second and third pairs with both rami longer and much narrower than those of the first pair, and furnished with densely plumose setæ on the inner margins and short stout spines on the outer; under the microscope these spines are seen to end in minute hooks. The inner ramus in the fourth pair narrower and rather longer than the outer, and bearing a single plumose seta on the inner distal angles of the first and second joints, and also three apical setæ, the middle one being longer than the one on either side. Fifth pair consisting each of a single two-jointed ramus, the first joint being very short, the other of moderate length and bearing one marginal and three terminal setæ. Caudal rami short. Length about $1.3 \mathrm{~mm}$.

Habitat.-Found parasitic on the back of the common sole, Solea vulgaris Quen., and in the nasal fossæ of various fishes, especially of cod-fishes: it has been 
found much more frequently in the nostrils of the cod than in those of any other fish we have examined. The following is a list of the fishes on which we have obtained this Bomolochus :-

1. Lumpsucker, Cyclopterus lımpus L., in the nostrils, rather rare.

2. Cor fish, Gadus callarius L., in the nostrils, frequent.

3. Haddock, Gadus æglefinus L., in the nostrils, not common.

4. Whiting, Gadus merlangus L., in the nostrils, not common.

5. Pollack or lythe, Gadus pollachius L., in the nostrils, moderately frequent.

6. Ling, Molua molva L., in the nostrils, not common.

7. Plaice, Pleuronectes platessa L., in the nostrils, not very rare.

8. Flounder, Pleuronectes flesus L., in the nostrils, rare.

9. Common or black sole, Solea vulgaris Quen., on the back of the fish, not common.

Bomolochus soleæ has been obtained at various places round the British Islands on one or other of the fishes mentioned. The specimens obtained on the ling-fish are rather larger than the typical form from the black sole or the cod-fish, but they do not appear to differ much otherwise. As many as twenty-nine specimens of Bomolochus have been obtained in the nostrils of a single large cod-fish captured in the Moray Firth. Frequently, not only adult males and females (the latter commonly with ovisacs), but also young ones in all stages of development, may be observed in the nostrils of the cod-fish, thus indicating clearly enough that their presence in this curions domicile is not accidental, and that they find the conditions of life fairly satisfactory amid such surroundings, even though the accommodation is somewhat limited. This habit on the part of the Bomolochus is the more interesting when there is apparently nothing to hinder them from leaving the nostrils of the fish. They can move about freely amongst the mucus with which the nostrils are usually well supplied, and if they be removed and placed in a vessel of clear sea- 
water they will be seen swimming or running about with nearly as much agility as a "free-swimming" species. It is fairly evident therefore that the presence of these Copepods in the nostrils of fishes is a matter of choice, and there is nothing to show that their presence is the cause of much inconvenience to the fish. Moreover, in this situation there are two points in favour of the Copepod-it has plenty of food of a kind, and it is well sheltered from its enemies.

The male does not differ much from the female except that the second maxillipeds are armed with more powerful terminal claws.

\section{Bomolochus onosi T. Scott.}

\section{(Plate I, fig. 4 ; Plate III, figs. 5-7.)}

1902. Bomolochus onosi T. Scott. (114) p. 289, pl. xiii, figs. 19-22.

Female.-Body elongated, subpyriform; the anterior segment proportionally larger than the same segment in Bomolochus solex, being equal to nearly half the entire length of the cephalothorax; the next three segments subequal in length, but each narrower than the one that precedes it. Abdomen narrow and moderately elongated, genital segment twice the length of the next one, other segments smaller, but the anal rather longer than either of the two preceding segments. Caudal rami about as long as the anal segment.

Antennules moderately stout, but becoming somewhat attenuated towards the distal extremity; the first two joints tolerably large, the second being about one and a half times the length of the next, the third and fourth joints subequal and larger than those which follow, the penultimate joint smaller than any of the others; the plumose setæ with which the antennules are furnished, though somewhat similar to those on the antennules of Bomolochus solex, are apparently not quite so stout. Antennæ, mandibles, and maxillæ somewhat similar to the same appendages in Bumolochus solex. Second maxillipeds robust, and each armed with a tolerably stout and strongly curved terminal claw; a slender seta also springs from the distal end 
of the inner margin of the first joint, and two smaller setæ from near the middle of the second joint, while from the proximal half of the terminal claw there spring two slender bristles of unequal length, the longer one extending considerably beyond the end of the claw.

Thoracic legs somewhat similar in structure and armature to those of Bomolochus solex. Length about $1 \cdot 3 \mathrm{~mm}$.

The species is colourless, with the exception of a slight chalky whiteness along the alimentary tract.

Male.-The male of Bomilochus onosi differs little from the female, except that the terminal claw of the second maxillipeds is more powerful, more evenly curved, and has its inner edge minutely dentated.

Habitat.-Found parasitic on the inner surface of the gill-covers of four-bearded and five-bearded rocklings, Onos (Motella) cimbrius and Onos (Motella) mustelus. Firth of Forth, Moray Firth, and Bressay Shoal, east of Shetland (T. Scott).

The species nescribed above has a close resemblance to Bomolochus solex, and might easily be mistaken for it. The most obvious difference is perhaps in the form and armature of the posterior maxillipeds; this difference is so marked that it may be detected even without dissection, when the creature is viewed from the ventral aspect with the aid of a hand-lens.

\section{Bomolochus zeugopteri T. Scott.}

\section{(Plate I, fig. 2; Plate III, figs. 8, 9.)}

1902. Bomolochus zeugopteri T. Scott. (114) p. 290, pl. xiii, figs. 23-25.

Female.-Cephalic segment equal to the combined length of the next three segments, broadly rounded in front, rostrum not very prominent; the next segment nearly as wide as the preceding one, and about half as long, the remaining segments narrower and shorter. Abdomen narrow, the genital segment about as long: as the combined length of the next three segments, the last two segments subequal and rather shorter than the second one. Caudal rami short. 
Antenmules tolerably stout, shorter than the cephalothorax and bearing numerous and moderately stout plumose setæe, first and second joints large, and, together, about as long as the combined length of the next four, the third and fourth joints subequal, and the penultimate joint shorter than any of the others. Second maxillipeds tolerably stout, the terminal claw only slightly curved at the end, but at the base bent backward upon the preceding joint. Thoracic legs somewhat similar to those of Bomolochus onosi. Length about $0.84 \mathrm{~mm}$.

No males of this species have been observed.

Habitat.-Found adhering to the back of a small Müller's top-knot, Zeugopterus punctatus (Bl.), captured near the mouth of the Clyde estuary in September, 1897. About a dozen specimens, all females, and most of them carrying ovisacs, were obtained; they were adhering firmly on the rough dark-coloured side of the fish.

This species is at once distinguished by the marked difference in the structure and armature of the second maxillipeds; it is also a smaller species than the other two described above.

\section{Genus 3. THERSITINA Norman, 190..**}

Syn. Thersites Pagenstecher 1861, a name preoccupied by Pfeiffer

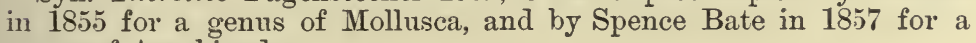
genus of Amphipoda.

Ergasilides having the cephalic segment in the female greatly enlarged and subglobular; other thoracic and abdominal segments small.

Antennules short, stout, and composed of five joints. Antennæ also short, rather stout, and armed with a tolerably strong, claw-like, terminal spine, from the side of which springs a second and smaller one. Mandibles, maxillæ, and first maxillipeds somewhat similar in structure to the same appendages in the Lichomolgidæ. Second maxillipeds small, two- or

* 'Museum Normanianum,' III, Crustacea, second edition, p. 41. 
three-jointed, and bearing a few stout apical spines. Thoracic legs nearly as in Ergasilus.

In the male the cephalic segment is not so much enlarged, and the body is more elongated.

\section{Thersitina gasterostei (Pagenstecher).}

(Plate XXV, figs. 1-6; Plate LI, fig. 6.)

1861. Thersites gasterost $i$ Pagenst. (94) vol. xvii, p. 118, pl. vi, figs.1-9. 1863. Ergasilus gasterostei Kröyer. (71) p. 233, pl. xii, figs. 2, $a-h$.

1892. Thersites gasterostei Canu. (29) p. 245, pl. xxiii, figs. 13-18.

1899. Ergasilus gasterostei Bassett-Smith. (8) p. 444.

1900. Thersites gasterostei T. Scott. (112) p. 146, pl. v, figs. 1-7.

1905. Thersilina gasterostei A. M. Norman. Museum Normanianum, III, Crustacea, second edition, p. 41.

F'emale-Cephalic segment considerably dilated, and, when viewed from above, concealing the remaining thoracic segments as well as part of the abdomen; genital segment of the abdomen longer than the combined length of all the other abdominal segments. Caudal rami short.

Antennules very short, tolerably - stout, and composed of five joints, which are sparingly setiferous. The formula shows their proportional lengths.

\begin{tabular}{llllllll} 
Numbers of the joints. & $\cdot$ & 1 & 2 & 3 & 4 & 5 \\
\hline
\end{tabular}

Proportional lengths of the joints $\overline{16} 101178$

Antennæ short and stout, and each furnished with a tolerably strong terminal claw. Mandibles with a bilobed biting part. First maxillipeds short, simple in structure, and provided with a few small spines. Second maxillipeds small, basal part enlarged, terminal part more slender, forming a curved arm which is furnished with a few apical spines.

The first three pairs of swimming-legs with both rami three-jointed, but the outer ramus rather shorter than the inner. In the fourth pair the outer ramus is only two-jointed, the elongated first joint consisting probably of two coalescent joints; the inner ramus three-jointed as in the preceding three pairs. Length about $0.8 \mathrm{~mm}$. ( $\frac{1}{30}$ of an inch).

Habitat.-Parasitic on certain fresh-water fishes, 
usually on the inner surface of the gill-covers. On three-spined sticklebacks, Gisterosteus aculeatus, captrired in Sinclair Loch, Barra, Onter Hebrides, in May 1894. On the same species of fish captured in the river Forth near Alloa in February 1896; and in brackish pools on Aberdeen links in 1900. Taken also on a fifteen-spined stickleback, Gastrær spinachia, captured in Loch Etive, West Coast of Scotland, in May 1896.

This Copepod, which has been ascribed by some authors to the genus Ergasilus, does not agree very well with some of the characters of that genus. The typical female Ergasilus has the body tolerably elongated, but in Thersitina it is nearly globose; the structure and size of the antennæ are also altogether different. On account of these and one or two other differences, as, for example, in the structure of the mandibles and second maxillipeds, we prefer to retain the species in the genus to which it was ascribed by Pagenstecher.

\section{Tribe II. CALIGOIDA G. O. Sars.}

Head usually in the form of a buckler or shield, with or without frontal plates: in some cases the frontal plates are provided with sucking disks. Thorax consisting of several, usually more or less distinct, rings or segments, with their margins sometimes produced into flattened scales or plates. Abdomen or urosome composed of two or three segments, the genital segment being, in the female, sometimes considerably expanded (ex. Caliqus), or elongated (ex. Hatschelici).

Mouth-apparatus consisting usually of a syphon provided with styliform mandibles and other accessory appendages. Usually there are also four pairs of thoracic limbs, but in some genera one or two pairs may be wanting. A fifth pair, more or less rudimentary, is also sometimes present.

The species comprised in this tribe are all, in the adult stage, parasitic on fishes. They are not permanently fixed to their host, but both the female and male possess a certain 
freedom of locomotion, closely approaching in some cases that of the normal free-swimmers; usually however their movements appear to be more or less restricted. 'They retain their position on the fish, at least to a considerable extent, by means of the strong terminal hooks with which certain of their appendages are furnished, such as the second pair of antennæ, the maxillipeds, and one or two others.

'The young leave the eggs as free-swimming nauplii.

The Caligoida comprise the three families Caligidæ, Dichelestidiæ, and Philichthyidæ, the first two of which are represented by a considerable number of genera and species.

\section{Family iI. Caligide.}

Carapace tolerably broad, more or less flattened, provided with anterior frontal plates. Free thoracic segments uncovered or sometimes more or less concealed by paired dorsal plates. Antennules small, twoor three-jointed. Antennæ forming short, movable, hooked claws. Mouth a suctorial beak formed by a modification of the upper and lower lips, and inclosing styliform mandibles. Second maxillipeds stout, with strong terminal claws. First four pairs of thoracic legs all biramose, or the first and fourth pairs may be uniramose. Fifth pair rudimentary. Eyes median, contiguous, sometimes obsolete. Egg-strings two, usually elongated.

The male is generally smaller than the female.

In some genera the mature stage is preceded by that of the chalimus, or young stage, which is temporarily fixed to the host by a more or less elongated slender frontal filament ( $c f$. Pl. IV, figs. 3-5).

\section{Genus 4. CALIGUS o. F. Müller, 1785.}

Carapace large, flattened, shield-like Frontal plates provided with small but conspicuous sucking-disks or lunulæ. Fourth pair of thoracic legs uniramose. Fifth pair rudimentary, and very small. Genital segment in the female usually expanded and moderately large. Abdomen short or moderately elongated and composed 
of one or two segments; caudal rami short. Dorsal plates wanting.

\section{Caligus curtus O. F. Müller.}

\section{(Plate XXIV, figs. 1, 2 ; Plate XXV, figs. 7-9.)}

1785. Caligus curtus O. F. Müller. (86) p. 130, pl, xxi, fig. 1 .

1816. Caligus mulleri Leach. (74) p. 405, pl. xx.

1832. Caligus bicuspidatus Nordmann. (89) p. 28.

1850. Caligus diaphanus Baird. (4) p. 269, pl. xxxiii, fig. 1.

1863. Caligus æglefinı Kröyer. (71) p. 89, pl. vii, fig. 3, $a-f$.

Female.-Carapace oval and fully half the entire length of the animal, rather longer than broad, widest behind and becoming gradually narrower towards the front, lateral margins slightly rounded, frontal plates tolerably large and furnished with conspicuous lunulæ. Genital segment subquadrangular, rather longer than broad, and equal to about one-fourth of the entirelength. Abdomen narrow and scarcely equal to one-third the length of the genital segment. Caudal rami very short and furnished with about four short setæ.

Antennules short, the basal joint slightly expanded and its margin densely setiferous; end joint narrow. The second maxillipeds consisting of a stout basal joint, and an end joint which is narrow and armed with two small terminal claws, one being larger than the other. Branches of the sternal fork short, moderately stout, and slightly divergent, also bluntly rounded at the end. Basal joint in the first pair of thoracic legs tolerably stout, and bearing a single, short, twojointed branch; the joints narrow and subequal, the first armed with a short spiniform seta on its outer distal angle; the last with two short apical spines, and a moderately long one which is curved and claw-like. The fifth pair of legs very small and situated near the postero-lateral angles of the genital segment.

Length about $10 \mathrm{~mm}$., width equal to about half the length, but the size varies to some extent.

The species is of a brownish or horn colour, which is apparently uniform, but when viewed with a hand- 
lens, irregular stellate markings are seen scattered over the surface of the carapace.

Male.-In the male, the average dimensions of which, contrary to what is usual among the Caligidæ, distinctly exceed those of the opposite sex, the carapace is proportionally larger and the genital segment smaller than in the female. The antennæ and the second maxillipeds are more robust and form more powerful grasping organs. The form of the carapace also differs somewhat in being proportionally wider behind, and in tapering more towards the front. The total length of the male is about $13 \mathrm{~mm}$. and the width $7.5 \mathrm{~mm}$., but, as in the female, the size varies somewhat, ranging, according to C. B. Wilson, from 13 to $20 \mathrm{~mm}$. in length, and from $7 \cdot 4$ to $11.5 \mathrm{~mm}$. in width of carapace.

Habitnt.-Parasitic on various kinds of fishes, but especially on Gadoids, and it has been obtained in abundance along with some other species on diseased cod-fishes.

'This species, first recorded by O. F. Müller in 178.5, is regarded as the type of the genus. It is, mnlike Caligus rapax, rarely captured as a free-swimmer, neither is it usual to find it on the gills or within the gill-covers of fishes, being more frequently observed adhering to, or moving about over the external surface of the fish.

Caligus curtus is a common form around our shores, and appears also to be widely distributed in the North Sea and the North Atlantic. It has been recorded as abundant during: the autumn along the eastern sea-board of the Now England States of North America.*

\section{Caligus minimus Otto.}

(Plate IV, figs. 1, 2; Plate XXV, figs. 11-16.)

1828. Caligus minimus Otto. (93) vol. xiv, p. 354, pl. xxii, figs. 7,8 . 1826. Caligus minimus Risso. (105) p. 135.

1840. Caligus minutus M. Edwards. (43) vol. iii, p. 450.

1865. Caligus minutus Heller. (58) p. 163, pl. xiv, fig. 1.

1899. Caligus minimus Bassett-Smith. (8) p. 447 .

* 'North American parasitic Copepods,' by C. B. Wilson (Caliginæ).

' Proc. U. S. National Museum,' vol. xxviii, p. 581 (1905). 
1901. Culigus minimus A. Scott. (107) vol. xv, p. 349, pl. i, figs. 1-8.

1905. Caligus minimus T. Scott. (116) p. 109.

1906. 'Caligus minimus Norman \& T. Scott.' (88) p. 205.

1906. Caligus minimus A. Brian. (21) p. 36.

Female.-Carapace suborbicular and scarcely equal to half the entire length; frontal plates and lunulæ large. Eyes conspicuous. Free thoracic segment narrow. Genital segment rather less than a third of the total length, and equal in width to about twothirds that of the carapace; the postero-lateral angles somewhat produced into narrow rounded lobes. Abdomen uniarticulate and narrow, becoming slightly expanded anteriorly, equal in length to about twothirds that of the genital segment. Caudal rami about half as long as the abdomen.

Antennules short; end joint tolerably elongated and narrow. Sternal fork small, the stem moderately long with short and somewhat divergent branches. Fourth pair of thoracic legs tolerably elongated, basaljoint stout, ramus two-jointed, joints subequal, the first with a small spine on the outer distal angle, the second furnished with one moderately long and two short apical spines as shown in the figure ('l. XXV, fig. 15). 'The fifth pair consisting each of a minute setiferous plate near the postero-lateral corners of the genital segment.

Male.-The male is larger than the female, and differs from it chiefly in the form of the genital segment; this segment is not much wider than either the free thoracic segment or the abdomen. The appendages are somewhat similar to those of the female, except that the second maxillipeds are considerably expanded distally, and are each armed with a strong claw, so that they form powerful grasping. organs. The branches of the sternal fork in the male are scarcely if at all divergent.

Total length of the female about $5 \mathrm{~mm}$., and of the male about $7 \mathrm{~mm}$.

Habitat.-Parasitic on the bass, Labrax lupus. Usually found inside the gill-covers, ${ }^{\circ}$ in the mouth of 
the fish. Belfast (Thompson, 1856). Plymouth (Bassett-Smith). Barrow Channel, Lancashire (A. Scott). Queensferry, Firth of Forth (T. Scott).

The species does not appear to be very rare.

Distribution. - European Seas. Mediterranean (Brian).

Caligus minimus, judging from the occurrences of this parasite known to us, appears to be restricted almost entirely to the bass. We do not know of its occurrence on any other kind of fish.

\section{Caligus rapax M. Edwards.* \\ (Plate IV, figs. 3-8; Plate VI, figs. 1, 2.)}

1840. Caligus rapax M. Edwards. (43) vol. ii, p. 453, pl. xxxviii, fig. 9. 1840. Caligus elongatus idem. (43) vol iii, p. 454.

1850. Culigus rapux Baird. (4) p. 270. pl. xxxii, figs. 2 and 3. 1861. Caligus rapax Stp. and Lkt. (127) p. 359. pl. ii, fig. 4. 1900. Caligus rapax T. Scott. (112) p. 148, pl. v, figs. 13-19. 1905. Caligus rapax C. B. Wilson. (145) p. 594, pl. vii, figs. 79-89.

Female.-Carapace orate, rather longer than broad; frontal plates slightly rounded; lunulæ large and conspicuous; thoracic area fully half the entire width of the carapace; its posterior margin broadly rounderl and produced somewhat beyond the narrowly-rounded lateral lobes. Free thoracic segment narrow, very short, and scarcely more than half the width of the next one. Genital segment quadri-lateral, about as long as broad and equal to about half the length of the carapace. Abdomen short, unsegmented, and about half the width and scarcely two-thirds the length of the genital segment. Caudal rami short, and furnished with moderately long plumose setæ.

Antennules tolerably large. Antennæ small, simple, and armed with a small marginal tooth. Mandibles elongated and narrow, terminal portion incurved and toothed on the inner edge. Maxillæ small. First maxillipeds slender and furnished with two slightlycurved terminal claws of unequal length; second

* For a more detailed synonymy of this common species see 'North American parasitic Copepods,' by C. B. Wilson (Caliginæ). 'Proc. U. S. National Museum,' vol. xxviii, p. 568 (190j). 
maxillipeds moderately stout. Sternal fork conspicuous, its rami narrow, tolerably elongated, slightly divergent, and with the ends blunt-pointed.

The first three pairs of thoracic legs short, biramose, with both rami three-jointed; fourth pair onebranched, basal joint elongated, tolerably stout, and furnished with a small seta on the upper distal angle; end portion narrow and consisting of two subequal joints, the first with the outer distal angle slightly produced and bearing a short spiniform seta, the other with a spiniform seta near the middle of the outer margin and four at the apex, the second from the inside being elongated, slightly curved and claw-like. The fifth pair rudimentary, each consisting of a minute plate bearing a few small setæ, and situated near the postero-lateral angles of the genital segment.

Length about 5 to $6 \mathrm{~mm}$. Egg-strings not greatly elongated.

Male.-The male is smaller than the female; the form of the carapace is somewhat similar in the two sexes, but the genital segment is narrow and scarcely wider than the preceding one. Abdomen as long as the genital segment and composed of two joints, the end joint being about twice as long as the other. Caudal rami as in the female.

The antennæ and second maxillipeds are stouter than those of the female, and are provided with stronger terminal claws; the other mouth-appendages and the thoracic legs are similar to those of the female. Length about 4 to $5 \mathrm{~mm}$.

Habitat.-Found parasitic on various fishes, but perhaps most frequently on Gadoids. It is also not uncommon in plankton collections, among Calanoids and other free-swimming organisms; both males and females are frequently captured in this way, and the latter are generally without egg-strings. Owing to the wandering habits of this Caligus there is scarcely a fish in our seas on which it may not at one time or other be found. 
Caligus rapax is apparently widely distributed in the North Sea and North Atlantic, and is, according to C. B. Wilson, " the most common species of the genus on the north-eastern coast of the United States, having been taken from more than twenty-five different kinds of fish by many collectors working in the interests of the United States Fish Commission" ('Proc. U. S. National Museum,' vol. xxviii, p. 571).

A certain amount of variation occurs in the size of different specimens of this species, and also in the proportional dimensions of the different parts. 'The colour' is also somewhat variable; it seems to change to some extent with the colour of the fish.

\section{Caligus centrodonti Baird.}

(Plate V, figs. 1-3; Plate XVIII, figs. 1-3.)

1850. Caligus centrodonti Baird. (4) p. 272, pl. xxxii, figs. $6,7$.

1863. Caligus abbreviatus Kröyer. (71) p. 61 , pl. iii, figs. $3 a-h$.

1905. Caligus abbreviatus T. Scott. (116) p. 109, pl. v, figs. 1-6.

1905. Caligus centrodonti C. B. Wilson. (145) p. 652, pl. xxvii, figs. 333,344 .

Female.-Length of carapace about equal to the width, and to two-thirds of the entire length of the animal, widest posteriorly, and becoming considerably narrower towards the front. Frontal plates large, lunulæ prominent. Free thoracic segment very short. Genital segment short and subquadrangular in outline, the width equal to about one and a half times the length, and fully half as wide as the carapace; greatest width near the anterior end; lateral margins obliquely rounded, posterior margin slightly concave. Abdomen very short, small, uniarticulate, and scarcely reaching beyond the lateral lobes of the genital segment. Caudal rami also very short, with four or five short setæ round their distal ends. Antennules moderately short. Sternal fork stout, with tolerably stout and slightly divergent rami. Maxillæ and maxillipeds and also the first three pairs of thoracic legs resembling those of the species already described; the fourth pair elongated, the basal joint moderately stout and furnished with a lobulate process on its upper aspect; the single two-jointed ramus somewhat slender; the 
proximal joint of the ramus short and scarcely half the length of the other, and bearing a tolerably long straight spine on its outer distal angle; the end joint narrow and provided with three terminal spines, the outermost similar to that on the preceding joint, the middle one slender and nearly as long as the joint, and terminating in a curved claw-like extremity, the innermost spine, a small one, appearing to be merely a prolongation of the inner distal angle of the joint. Fifth pair nearly obsolete. Egg-strings tolerably stout but not very elongated. Length about $4 \mathrm{~mm}$.

Male.-The male is somewhat similar to the female but larger. A specimen examined by us, which was found to be a male-not a female as stated in the Fishery Board's Report-measured five millimetres in total length. The carapace was suborbicular and distinctly larger in proportion to the total length, while the genital segment was much smaller than in the female, and the posterior margin of this segment was also more deeply concave, so much so that the posterolateral angles reached beyond, and enclosed the very short abdomen. The caudal rami were also very short.

Antennules and frontal plates tolerably large. Second maxillipeds large, with the end-joint considerably expanded and provided with a strong, hinged, terminal claw, so as to form powerful grasping organs as shown in the drawing (Pl. XVIII, fig. 2).

Habitat.-Parasitic on the tail and fins of the seabream, Pagellus centrodontus, and of the ballan wrasse, Labrus bergylta. Dublin, 1837, on Pagellus centrodontus (Baird). Plymouth, on Pagellus centrodontus (Bassett-Smith). Moray Firth, on Labrus berg!lta. (T. Scott).

There can be no doubt that the species described by Kröyer in 1863 under the name of Caligus abbreviatus is identical with Baird's C. centrodonti. The peculiar form of the genital segment, the very short abdomen and caudal rami, together with the structure and armature of the fourth pair of thoracic legs, establish the identity of the two forms. 
In Charles Branch Wilson's figure of the fourth pair of legs all the three spines with which the end joint is furnished spring from the apex, whereas in our specimen the outer. spine springs from a notch on the outer margin a short distance from the apex.

A young specimen representing the chalimus stage of this Caligus (Pl. V, fig. 3) was obtained along with the adult. The siphon is still present showing a dilated, two-jointed base; the carapace is elongate-ovate in outline, the free thoracic segment is concealed, and the abdomen is very short. The frontal plates also slope backwards at a considerable angle.

The distribution of Caligus centrodonti, so far as known, appears to be somewhat limited. 'The only record, other than those for the British Islands, is that of Kröyer. The specimen recorded by him as Caligus abbreviatus was obtained on a Labrus bergylta at Bergen in 1839. The species is described in C. B. Wilson's work on 'North American parasitic Copepods,' but the specimens, which were taken in the gillcavity of Pagell.us centrodontus, were sent from England by the Rev. A. M. Norman.

\section{Caligus gurnardi Kröyer.}

\section{(Plate VIII, figs. 1, 2.)}

1863. Caligus gurnardi Kröyer. (71) ser. 3, vol. ii, p. 150, pl. ii, figs. $3 a-g$.

1896. Caligus gurnardi Bassett-Smith. (7) p. 157.

Female.-Carapace equal to about three-fifths of the total length, and rather longer than broad; frontal plates only slightly arcuate, lunulæ rather small. Free thoracic segment distinct, small; genital segment obcordate, about half as long as the carapace, its greatest width about equal to the length, posterior margin subtruncated. Abdomen short, uniarticulate, length scarcely equal to twice the width. Caudal rami short.

Antennules of moderate size, the end joint narrow and about as long as the proximal one. Sternal fork tolerably large with moderately long and somewhat divergent branches. Fourth pair of thoracic legs elongated with the ramus biarticulate. Length $6-7 \mathrm{~mm}$. 
Male.-The male is somewhat similar to the female in general appearance but the genital segment is much smaller, its width being scarcely a third of the width of the carapace; the segment is also not much longer than broad. The abdomen is composed of two joints, and the end joint is much shorter than the proximal one. The cephalothoracic appendages appear to be similar to those of the female except that the second maxillipeds are rather stronger, and the fourth pair of thoracic legs of proportionally greater length.

Habitat.-Parasitic on Trigla spp., usually lodged in the gill-cavity. Found at Falmouth in 1884 (A. M. Norman). Plymouth on Trigla cuculus (Bassett-Smith). Kröyer obtained this species on Trigla gurnardus.

We have not seen this species, but it appears to have an extensive distribution; besides being recorded from the Norwegian and British seas, C. B. Wilson mentions its occurrence on fishes captured on the coast of California, viz. on a king salmon taken at Monterey and on an elephant fish at La Tolla.*

\section{Caligus labracis T. Scott.}

(Plate V, figs. 4, 5; Plate XVIII, figs. 4, 5.)

1902. Caligus labracis T. Scott. (114) p. 291, pl. xiii, figs. 26-29.

1904. Caligus labracis A. Scott. (109) p. 38.

Female.-Carapace suborbicular, length and width about equal, lateral margins evenly rounded, frontal plates large, lunulæ prominent. Free thoracic segment subquadrangular, considerably shorter than the carapace, and a little more than one fifth of the total length; the width of the segment exceeding the length by about one fourth. Abdomen short, uniarticulate, and about one half as long as the genital segment. Caudal rami very short.

Antennules short. Mouth-appendages somewhat similar to those of Caligus diaphanus Nordmann. Sternal fork stout, with tolerably broad and slightly

* 'North American parasitic Copepods : A list of those found upon the fishes of the Pacific coast,' etc. 'Proc. U. S. National Museum,' vol. xxxv, p. 439 (1908). 
divergent branches, which have their ends obliquely truncated. Fourth pair of thoracic legs small, basal joint tolerably stout; ramus short, two-jointed, and armed with sabre-like spines, the first joint with one on the outer distal angle, and the second with two at the apex, the spines moderately elongated, those at the apex being longer than the joint from which they spring, also with a minute tooth on the inner distal angle. The fifth pair consisting each of a minute setiferous plate on the postero-lateral angle of the genital segment. Egg-strings short, containing a comparatively small number of tolerably large ova. Length about $3.5 \mathrm{~mm}$.

Male.-The male is smaller than the female, being only about $2.6 \mathrm{~mm}$. in total length. It does not differ greatly from the female except that, as usual, the second maxillipeds are larger and the genital segment is much smaller. Colour reddish-brown, broken up into minute patches of a lighter and darker coloration.

Habitat.-Parasitic on the gills of a striped wrasse, Labrus mixtus L., captured in the Firth of Clyde in January 1900, and sent to the Laboratory of the Fishery Board for Scotland at Aberdeen by Mr. Robert Duthie, the Fishery Officer at Girvan. Also found on the gills of Labrus mixtus and Labrus maculatus captured in the Irish Sea $(A$. $S$ cott).

\section{Caligus zei Norman and T. Scott.}

(Plate VII, fig. 1 ; Plate VIII, figs. 3-9.)

1906. Caligus zei Norman \& T. Scott. (88) p. 206, pl. xxii, figs. 1-8. 1907. Caligus zei A. Scott. (111) p. 93, pl. i.

Female-Carapace suborbicular, length and breadth nearly equal, margins only slightly arcuate. Frontal plates and lunulæ of moderate size. Free thoracic segment about as long as broad, rather small. Genital segment subquadrate and equal to about a third of the entire length of the animal; length and width nearly equal, and the postero-lateral angles, which are 
rounded, slightly produced so that the posterior margin between the rounded angles is more or less incurved. Abdomen short and uniarticulate. Caudal rami small. Antennules rather longer than usual, the second joint being about five times longer than broad and much longer than the first joint. Antennæ sharply hook-formed. First maxillipeds elongated and slender, the second joint long and narrow, and furnished with two tolerably long spiniform and claw-like setæ, the outer one being rather longer than the inner. The second maxillipeds moderately large; the basal joint stout but the end one short and narrow, and armed with a tolerably stout terminal claw. Sternal fork small, with moderately long and slightly tapering branches which are also somewhat divergent. The fourth pair of thoracic legs moderately elongated; basal joint narrow and about as long as the twojointed ramus ; the joints of the ramus of nearly equal length, the proximal joint provided with a stout spine on the outer distal angle, but the end joint with four spines, one near the middle of the outer margin, and three at the apex, the middle one rather longer than the one on either side. The fifth pair, which are very small, situated near the postero-lateral corners of the genital segment. Length about $5 \bullet 5 \mathrm{~mm}$.

Male.-The genital segment in the male is as usual considerably smaller than in the female; it is narrow and scarcely twice the width of the abdomen. The abdomen, which is longer than in the female, is composed of two segments, the first being rather shorter than the second. The thoracic and other appendages are somewhat similar to those of the female except that the second maxillipeds are stronger.

Habitat. - Taken forty years ago on the dory, Zeuls faber, at Polperro by Laughrin, and sent by him to A. M. Norman.* Several specimens were found attached to the skin of a Zeus faber captured off

* 'Crustacea of Devon and Cornwall,' by the Rev. A. M. Norman and T. Scott, p. 207 (1906). 
New Quay Head on 16th June 1906; also on specimens of the same fish captured off Puffin Island in 1908; on Zeus faber taken in Luce Bay, September 1911 (A. Scott).

This species may be distinguished from those closely allied to it by the unusual length of the second joint of the antennules, by the form of the sternal fork, and by the structure and armature of the fourth pair of thoracic legs.

\section{Caligus brevicaudatus A. Scott.}

(Plate VI, fig. 3 ; Plate VIII, figs. 10, 11 ; Plate XLVIII, fig. 6.)

1901. Caligus brevicaudatus A. Scott. (107) p. 349, pl. ii, figs. 7-10.

Female-Carapace suborbicular, rather wider posteriorly than in front, and equal to fully half of the entire length of the animal. Frontal plates large and slightly arcuate; lunulæ prominent. Free thoracic segment short and narrow. Genital segment oblong in outline, rather longer than broad, and equal to about half the width of the carapace. Abdomen very short and uniarticulate. Caudal rami also very short, and furnished with a few plumose setæ.

Antennules moderately stout, end joint rather shorter than the basal one. Sternal fork moderately stout, and with the rami also stout and scarcely divergent, and rounded at the tips. Second maxillipeds tolerably elongated, and slender, with somewhat feeble terminal claws. Fourth pair of thoracic legs small, and composed of three joints ; basal joint tolerably stout, ramus slender and rather longer than the basal joint; the terminal joint also rather longer than the preceding one; a small spiniform seta springing from the extremity of the basal joint on its upper aspect, and the first joint of the ramus provided with a similar seta on its outer distal angle; the end joint with three apical setæ which differ considerably in length, the inner one being about as long as the joint from which it springs, the outer scarcely half as long, the middle 
one intermediate in length to the others. Length about $5 \cdot 3 \mathrm{~mm}$.

Habitat.-Parasitic on Trigia gurnardus and Trigla lucerna. Found adhering to the inside of the month of a grey gurnard captured in the vicinity of Piel, Barrow-in-Furness, in August 1y01. Found also on the inside of the gill-covers of sapphirine gurnards taken in Luce Bay in October 1910 (A. Scott).

No males have been observed.

This species resembles Caligus curtus in general appearance, but differs in the form of the genital segment, in the very short abdomen and caudal rami, and in the structure and armature of the fourth pair of thoracic legs.

\section{Caligus pelamydis Kröyer.}

(Plate VII, figs. 2, 3; Plate IX, figs. 1-5; Plate LXXI, fig. 14.)

1863. Caligus pelamydis Kröyer. (71) p. 50, pl. iv, fig. 4a-g.

1896. Caligus scomberi Bassett-Smith. (6) p. 11, pl. ii, fig. 2.

1901. Caligus scomberi T. Scott. (113) p. 148, pl. v, figs. 9, 10.

1905. Caligus pelamydis C. B. Wilson. (145) p. 594, pl. xiii, figs. 154-161; pl. xiv, fig. $116 a$.

1906. Caligus scomberi A. Scott. (110) p. 52, pl. vi.

1906. Caligus pelamydis Norman \& T. Scott. (88) p. 206.

1910. Caligus pelamydis T. R. R. Stebbing. (125) p. 558.

Female.-Carapace suborbicular, length and width about equal and rather more than one-third the total length of the animal, lateral margins slightly arcuate; frontal plates tolerably large, lunulæ also of moderate size but not very prominent. Free thoracic segment short, narrow, somewhat dilated. Genital segment ovate, equal to fully two-thirds the length of the carapace, lateral margins nearly straight distally, but rounded and converging towards the anterior end, posterior margin truncated, postero-lateral angles rounded. Abdomen narrow, about as long as the genital segment, indistinctly biarticulated, end joint short and rather narrower than the elongated proximal one. Caudal rami short and provided with several short plumose setæ. 
Antennules moderately. stout; sternal fork rather small, narrow, and elongated, rami not divergent or but very slightly so. Fourth pair of thoracic legs stout, comparatively short, basal joint about as long as the ramus, which is composed of three short and moderately stout joints, the first being the largest, and having the outer distal angle produced so as to reach to near the end of the second joint, the first and second joints each provided with a moderately stont spiniform seta on the outer distal angle, the third joint of a triangular form and carrying three spiniform setæ, the end one being rather stouter than the others; the apex of the joint is produced slightly beyond the base of the end spine, forming a blunt-pointed knob fringed with minute setæ. From the peculiar form of the first and third joints the marginal and terminal setæ are crowded together, and as each seta is slightly longer than the preceding one, they impart a character to this species somewhat different from others, such as Caligus rapax. Fifth pair very minute. Egg-string's tolerably elongated.

This species appears to vary in length: the specimen figured here measured about $5 \cdot 5 \mathrm{~mm}$., and C. B. Wilson gives the length of his specimens as $3 \cdot 3 \mathrm{~mm}$.

Male.-The male of this Caligus does not appear to have been previously met with, and we are inclined to consider that it is much rarer than the female. The specimen of the male figured on Pl. LXXI, fig. 14, is the first and only one we have yet secured. It represents the result of the examination of nearly fifteen hundred mackerel. The specimen figured was found on the inside of the operculum of a mackerel caught in the northern part of the Irish Sea in July 1912. On that particular occasion two hundred fish were examined, and although several females were found only a single male could be detected. Caligus pelamydis resembles the male of Caligus rapax in general appearance, and without careful examination 
it might be readily passed over for that species. The abdomen is two-jointed and slightly shorter than the genital segment. The first joint is comparatively short and about equal to half the length of the second joint. The furcal joints are short and broad and nearly as long as the first abdominal segment. The specimen was not dissected, but so far as could be made out from the examination of the entire animal the various appendages are almost identical with those of the female. The fourth pair of feet of the female, which are quite distinct from those of any of the other members of the genus, form a quite reliable distinguishing character. 'I'he fourth pair of feet of the male now illustrated are identical with those of the female. The living male was dark red in colour, and it was easily detected running over the inner surface of the operculum of its host. Length $2.9 \mathrm{~mm}$.

Habitat. - Parasitic on the belted bonito, Pelamys sarda, and the mackerel, Scomber scombrus. Plymouth, on the inside of the gill-covers of mackerel (BassettSmith). Aberdeen (T. Scott). Irish Sea (A. Scott). Kröyer's specimens were obtained on Pelamys sarda.

Distribution.-Caligus pelamydis has apparently a wide distribution in the seas of Europe. C. B. Wilson describes this species in his work on 'North American parasitic Copepods,' and mentions the name of its host, but does not state if the fish was captured in American waters.*

We think there can be no reasonable doubt that the form obtained by Kröyer on Pelamys sarda, and described by him in the work referred to under the name of Caligus pelamydis, is identical with that from the mackerel; the general structure of the animal, the shape of the sternal fork and of the genital segment, and the structure and armature of the fourth pair of thoracic legs, are similar in both forms.

* See Part I (The Caliginæ), p. 594. 


\section{Caligus diaphanus Nordmann.}

(Plate XVII, fig. 1; Plate XVIII, figs. 6, 7 ; Plate XLVIII, fig. 7.)

1832. Caligus diaphanus Nordmann. (89) pt. 2, p. 26 (non C. diaphanus, Baird).

1863. Caligus diaphanus Kröyer. (71) p. 79, pl. vii, fig. 5 a-c.

1894. Caligus isonyx T. Scott. (111a) 12th Rept. Fishery Board for Scotland, pt. iii, p. 194.

1896. Caligus diaphanus Bassett-Smith. (6) p. 156.

1900. Caligus diaphanus T. Scott. (112) p. 149, pl. v, figs. 20-25.

1904. Caligus diaphanus A. Scott. (109) p. 38.

1906. Caligus diaphanus Norman \& T. Scott. (88) p. 206.

Female.-Carapace suborbicular and equal to about two-fifths of the entire length of the animal, and the width rather greater than the length. Frontal plates large, anterior margin slightly emarginate, lunulæ rather small, partly concealed. The free thoracic segment short and narrow; genital segment subcordate and equal to about two-thirds of the length of the carapace, truncated posteriorly, and the posterolateral corners bluntly rounded. Abdomen composed of two joints, and nearly as long as the genital segment, the end joint small. Caudal rami small.

Antennules of moderate size. Mandibles slender, elongated, with the end joint incurved and distinctly serrated on the inner margin. The fourth pair of thoracic legs short and stout, the ramus, which is composed of three short joints, has both the first and second joints provided with a stout seta of moderate size on the outer distal angle, while the end joint has three similar apical setæ; all the setæ plumose and of nearly equal size, except that the inner one is rather longer than the others. Fifth pair minute, and, as in the case of other species, occurring as minute setiferous plates near the postero-lateral corners of the genital segment. Length about $4.5 \mathrm{~mm}$.

Male.-The carapace of the male is rather wider in proportion to its length; the genital segment is small and scarcely twice the width of the abdomen, it becomes narrower towards the proximal end, and the postero-lateral corners are somewhat angular. The 
abdomen is composed of two subequal, angular segments, and is only equal to about one-sixth of the entire length.

Habitat.-Parasitic on various species of gurnards (Trigla). Belfast (W. Thompson). Found on the inner surface of the operculum of Trigla 7ivrundo and Trigla cuculus at Plymouth (Bassett-Smith). On Trigla spp., Firths of Forth and Clyde (T. Scott). Irish Sea (A. Scott).

The species is apparently not uncommon, but we have only met with it on gurnards.

\section{Genus 5. PSEUDOCALIGUS A. Scott, 1901.}

Carapace large and scutiform; frontal plates moderately prominent, and provided with lunulæ. Genital segment and abdomen as in Caligus. Cephalothoracic appendages also similar to those of Caligus, except that the fourth pair of thoracic legs are somewhat rudimentary, and consist each of a single small joint, furnished with a few minute terminal bristles.

This genus has, in its general appearance, a close resemblance to Caligus.

\section{Pseudocaligus brevipedes (Bassett-Smith).}

$$
\text { (Plate IX, figs. 6-9; Plate X, figs. 1, 2.) }
$$

1896. Caligus brevipedes Bassett-Smith. (6) p. 11, pl. iii, fig. 1.

1901. Pseudocaligus brevipedes A. Scott. (107) p. 350, pl. ii, figs. 1-6. 1902. Pseudocaligus brevipedes T. Scott. (114) p. 291.

1906. Pseudocaligus brevipedes Norman \& T. Scott. (88) p. 207.

Female.-Carapace suborbicular, about as long as broad, and equal to rather more than half the entire length of the animal. Frontal plates well developed, lunulæ of moderate size. Free thoracic segment small. Genital segment subquadrangular, and about half as long as the carapace, the length rather less than the width, and the lateral margins nearly straight, the posterior end also subtruncated, and the postero-lateral corners bluntly rounded. Abdomen consisting of a 
single joint, somewhat longer than broad, and scarcely equal to one-third of the length of the genital segment. Caudal rami of moderate size.

Antennules tolerably stout, and composed of two subequal joints. Antennæ with the end joint in the form of a strongly-hooked claw. Sternal fork small with tolerably short and slender rami which are moderately curved and somewhat divergent. The fourth pair of thoracic legs consisting each of a single joint, small and rudimentary and furnished with three spiniform setæ, two of them short and subequal, and the other tolerably elongated and plumose. 'The fifth pair in the form of minute setiferous plates near the postero-lateral corners of the genital segment. Length about $3 \cdot 6 \mathrm{~mm}$.

Male.-The male is rather smaller than the female, and differs from it chiefly by the small size of the genital segment. The carapace is also rather wider in proportion to the length, while the second maxillipeds are larger and form more powerful grasping organs.

Habitat.-Parasitic on the three-bearded rockling, Onos (Motella) tricirratc Brun., and usually found adhering to the inner surface of the gill-covers. Plymouth (Bassett-Smith). Irish Sea, Barrow Channel, and at Port Erin, Isle of Man $(A$. Scott). Dunbar, at the mouth of the Forth estuary, and near Aberdeen (T. Scott).

This species is easily distinguished by the rudimentary character of the fourth pair of thoracic legs in both sexes. From the records of the species published hitherto it seems probable that the distribution of the Pseudocaligus will be coextensive with that of the fish mentioned.

Genus 6. SCIÆNOPHILUS P. J. van Beneden, 1852.

Carapace somewhat similar to that of Caligus. Frontal plates distinct and provided with lunulæ. Free thoracic segment small. Genital segment narrow and considerably elongated. Abdomen slender and of great length. Caudal rami short. Mouth append- 
ages somewhat as in Caligus, but the second maxillipeds very large. Sternal fork absent. Thoracic legs nearly as in Caligus.

\section{Sciænophilus tenuis P. J. van Beneden. \\ (Plate XI, figs. 1-6.)}

1852. Scienophilus tenuis, P. J. van Beneden. (13) p. 464, and plate. 1861. Scienophilus tenuis idem. (15) p. 148, fig. 21.

1896. Sciænophilus tenuis Bassett-Smith. (6) p. 156.

1906. Sciænophilus tenuis Norman \& T. Scott. (88) p. 207.

Female.-Carapace small, suborbicular, length and width about equal. Frontal plates distinct, lunulæ small. Free thoracic segment small; genital segment elongated and narrow, but increasing in width gradually though slightly towards the posterior extremity, the greatest width being equal to about one fourth of the length, and the length equal to about three times the length of the carapace, the distal end slightly emarginate and the postero-lateral corners bluntly rounded. Abdomen extremely long and slender, fully twice the length of the genital segment and about as long as, and not much thicker than, the egg-strings. Caudal rami short, and provided with four to six apical setæ.

Antennules small, two-jointed, and similar to those of Caligus; mouth-appendages also similar. The second maxillipeds stout and elongated, and armed with strong curved terminal claws. The first pair of thoracic legs slender, and bearing at their distal end three strong and curved setiferous spines; only the second pair of legs distinctly biramose. The fourth pair elongated and uniramose, and consisting each of two tolerably long joints, the terminal one being furnished with a few marginal and apical setæ. Total length about $14 \mathrm{~mm}$. (fully half an inch).

We have not seen the male of this species.

Habitat.-Parasitic in the branchial chamber of the maigre, Sciæna aquila (or Sciæna umbra), Plymouth (Bussett-Smith). 
Dr. Bassett-Smith obtained four specimens of this curious parasite on the inside of the operculum of a maigre captured at Plymouth. 'Though this is the only British record of Sciænophilus we know of, Professor P. J. van Beneden states that the species is very common on the maigre, and he has seen such a great number of specimens crowded together that they resembled tufts of moss ("formant des touffes semblables à une mousse"). This fish is not common in the British seas, and, according to Aflalo, is taken only casually in the mackerel nets, and this probably is the reason why such a common parasite as this appears to be has not been more frequently recorded.

Sciænophilus tenuis, so named from its narrow and elongated form, has at first sight a close resemblance to a Hatschekia (Clavella), but the form and structure of the carapace reveal at once its near relationship with Caligus.

\section{Genus 7. LEPEOPHTHEIRUS Nordmann, 1832.}

Free thoracic segment without dorsal plates. Genital segment simple. Abdomen one- or two-segmented.

Mandibles serrated only on the inner edge. Second maxillæ small, furcate, the branches acuminate, not simple and spine-like as in Caligus. Fourth pair of thoracic legs and other thoracic appendages as in Caligus.

Both the females and the males have a general resemblance to those of Caligus, but the frontal plates are without lunulæ.

\section{Lepeophtheirus pectoralis (O. F. Müller).}

(Plate X, figs. 3-4; Plate XII, figs. 2-3; Plates XIII, XIV, XV; and Plate XVI, figs. 1-3.)

1777. Lernæa pectoralis O. F. Müller. (85) Zool. Danica, p. 41, pl. xxxiii, fig. 7 .

1838. Caligus pectoralis Kröyer. (70) (ii), p. 8, pl. vi, fig. 4.

1832. Lepeoplutheirus pectoralis Nordmann. (89) p. 30.

1847. Caligus pectoratis Thompson (129), p. 247.

1850. Lepeophtheirus pectoralis Baird. (4) p. 275, pl. xxxii, fig. 10.

1900. Lepeophtheirus pectoralis T. Scott. (112) p. 150 , pl. v, figs. 26-31.

Female.-Carapace suborbicular, length and width nearly the same, and scarcely equal to half the entire 
length of the animal. Frontal plates of moderate size, lunulæe wanting. Free thoracic segment small. Genital segment subquadriform and equal to about one-third of the entire length of the animal, with its posterolateral angles rounded. Abdomen short, with a slight constriction near the middle which in certain positions gives it the appearance of being obscurely twosegmented. Caudal rami very short.

Antennules of moderate size. Antennæ armed with strong, terminal, hooked claws. Mandibles small, slender, and with the inner edge of the distal joint distinctly serrated. Posterior maxillipeds strong and provided with stout terminal claws. Sternal fork moderately stout, with short and scarcely divergent rami, each ramus somewhat expanded in the middle and thence tapering to the pointed extremity. Fourth pair of thoracic legs short; the basal joint tolerably stout, and the ramus consisting of two subequal joints - the first with a small spine on the outer distal angle, and the second with three short terminal spines, each of the two inner spines being rather longer than the one in front of it. The fifth pair extremely small and situated near the postero-lateral angles of the genital segment. Length about $5 \mathrm{~mm}$.

Male.-'The male is little more than half the size of the female, but the carapace is proportionally larger, being equal to nearly two-thirds of the entire length of the animal. Genital segment small; abdomen also small and uniarticulate.

Habitat.-Found usually adhering to the underside of the pectoral fins of certain flat fishes, as plaice, Pleuronectes platessa, dabs, Pleuronectes limanda, and one or two others. Belfast (W. Thompson). Plymouth (Bassett-Smith). Irish Sea (A. Scott). Firths of Forth and Clyde (T'. Scott).

This is one of the more common and easily recognized of the species of Lepeophtheirus, but though widely dispersed in the seas of Europe it does not appear to have yet been recorded from American waters. 
2. Lepeophtheirus nordmanni (M. Edwards). (Plate XII, fig. 1 ; Plate XVI, figs. 4-11.)

1840. Caligus nordmanni M. Edwards. (43) p. 455.

1847. Caligus nordmanni W. 'Thompson. (129) p. 248.

1850. Lepeophtheirus nordmanni Baird. (4) p. 275 , pl. xxxiii, fig. 1 . 1865. Lepeophtheirus nordmanni Heller. (58) p. 180, pl. xvi, figs. 1, 2. 1884. Lepeophtheirus nordmanni Rathbun. (97a) Proc. U. S. National Mus., vol. vii, p. 487.

1900. Lepeophtheirus nordmanni T. Scott. (112) p. 151, pl. v, figs. 32-37.

1905. Lepeophtheirus nordmanni C. B. Wilson. (145) p. 623, pl. xix. figs. 223-233.

1909. Lepeophtheivus nordmanni E. V. Elwes. (45) p. 19.

Female-Carapace suborbicular, about as long as broad and equal to about half the entire length of the animal. Frontal plates narrow, without lunulæ. Free thoracic segment small, somewhat rhomboid in shape. Genital segment obovate, considerably narrower than the carapace, and equal to fully one-fourth of the entire length of the animal; length and width about equal, and with the postero-lateral corners forming rounded lobes so that the space between is deeply incurvated. Abdomen short, consisting of a single segment with a slight constriction near the middle. Caudal rami short.

Antennules of moderate size. Antennæ armed with tolerably long and strongly-hooked terminal claws. Mandibles slender and elongated, end joint comparatively short and finely serrated on the inner margin. Second maxillipeds moderately stout and elongated, and provided with strongly-hooked terminal claws. Sternal fork with the basal portion narrow, the rami also comparatively narrow and elongated, and somewhat divergent. Fourth pair of thoracic legs tolerably elongated, basal joint not very stout and rather shorter than the ramus, which consists of three subequal joints; the first and second joints of the ramus each provided with a short spine on the outer distal angle, the end joint with three moderately long apical spines, the outermost being scarcely so long as the other two. Length about $12 \mathrm{~mm}$. Egg-strings considerably elongated. 
Male.-The male, which is only about half the size of the female, has the carapace proportionally rather longer, and the frontal plates are more distinct. The free thoracic segment is also rather longer and the genital segment narrower than in the female, and the postero-lateral corners of the genital segment have eaclı two small angular processes, the one slightly anterior to the other. Abdomen short and about one third the length of the genital segment, and composed of two unequal joints - the proximal one being small. Caudal rami short and bearing several short setæ.

Habitat.-Parasitic on the short sun-fish (Orthagoriscus mola). Coast of County Antrim, Ireland, 1848 (W. Thompson). Polperro, Cornwall (A. M. Norman). Plymouth (Bassett-smith). Aberdeen (T. Scott). Found also on a short sun-fish captured off Berry Head (E. V. Elues).

L.nordmanni does not appear to be very commonly met with ; the sunfish when captured is usually subjected to some rough handling ere it reaches the market and the parasites get rubbed off.

C. B. Wilson records this species from both the Atlantic and Pacific Coasts of North America.

\section{Lepeophtheirus hippoglossi (Kröyer).}

(Plate VI, figs. 4, 5; Plate XVII, fig. 2 ; Plate XVIII, figs. 8-10.)

1838. Caligus hippoglossi Kröyer. (70) R. 1, vol. i, p. 625, pl. vi, fig. 3. 1850. Lepeophtheirus hippoglossi Baird. (4) p. 276 , pl. xxxii, fig. $12(q)$.

1850. Lepeophtheivus obscurus Baird. (4) p. 277, pl. xxxii, fig. 11 (ठَ).

1863. Lepeophtheirus lippoglossi Kröyer. (71) p. 131, pl. vi, fig. 5 a-d.

1900. Lepeophtheirus hippoglossi T. Scott. (112) p. 151, pl. v, figs. $38-42$; pl. vi, figs. $1,2$.

1905. Lepeophtheivus hippoglossi C. B. Wilson. (145) p. 625, pl. xx, figs. $234-243$.

Female.-Carapace somewhat longer than broad and equal to rather more than half the entire length of the animal, lateral margins gently and evenly arcuate. Frontal plates narrow, without lunulæ. Free thoracic segment small. Genital segment fully half the length 
of the carapace, width about three fourths of the length, lateral margins only slightly arcuate. Abdomen short, composed of a single segment; caudal rami short and bearing a few apical setæ.

Antennules small. Antennæ short and moderately robust, and armed with a stout sinuately-curved terminal hook. Mandibles slender but scarcely so much so as in Lepeophtheirus nordmanni. Second maxillipeds stout and provided with short but strong terminal claws. The sternal fork with the basal part somewhat expanded, the rami short, tolerably broad and divergent, each ramus truncated at the end and split into two portions by a longitudinal sinus, the inner portion being much narrower than the outer. Fourth pair of thoracic legs tolerably elongated, basal joint stout, ramus composed of three joints, the middle one being rather longer than the first or third; the outer distal angle of the first joint ending in a bluntly-rounded knob, the second joint bearing a short spine on its outer distal angle, and the end joint three terminal spines, the innermost of the three spines being longer than the other's and finely serrate along the outer margin. The fifth pair very small and rudimentary. Length about half an inch $(12.5 \mathrm{~mm}$.), but varying somewhat in different specimens. Egg-strings slender and elongated.

Male.-Carapace orbicular, as long as broad, and equal to about two-thirds of the entire length of the animal. Free thoracic segment very small, and slightly produced on each side. Genital segment very small, with a pair of minute setiferous processes on each side at the postero-lateral corners. Length about $6.5 \mathrm{~mm}$.

Habitat.-Parasitic on the backs of large halibut, Hippoglossus vulgaris Fleming. Berwick Bay (Dr. Johnston). Polperro, Cornwall (A. M. Norman). Aberdeen (T. Scott). Shetland (C. B. Wilson).

Distribution. - North Sea ’ Greenland, Iceland, Massachusetts (Cape Ann), U.S.A. 


\section{Lepeophtheirus thompsoni Baird.}

(Plate XVII, fig. :3 ; Plate XXV, fig. 10 ; Plate XLVIII, figs. 1-3.)

1850. Lepeophtheirus thompsoni Baird. (4) p. 278, pl. xxx, fig. 2.

1851. Caligus gracilis P. J. van Beneden. (11) p. 90, pl. ii, figs. 1-7. 1861. Caligus branchialis Malm, mser. \& Steenstrup \& Lütken. (127) p. 362, pl. ii, fig. 3 .

1863. Lepeophtheivus rhombi Kröyer. (71) p. 118, pl. v, fig. 5̆.

1885. Lepeophtheivus grucilis Carus. (29a) Prodr. Faunæ Mediterraneæ, p. 359.

1900. Lepeophtheirus thompsoni T. Scott. (112) p. 152, pl. v, figs. $43-45$.

1900. Lepeophtheirus obscurus idem. (112) p. 153, pl. vi, figs. 16-19.

1905. Lepeophtheirus thompsoni C. B. Wilson. (145) p. 619. pl. xviii, figs. 21:-219.

Female.-Carapace suborbicular and equal in length to about two-fifths of the entire length of the animal. Frontal plates arcuate, and tolerably prominent. Free thoracic segment small. Genital segment large and nearly as long as the carapace, widest at the distal end, which is about three-fourths the width of the carapace, but the width gradually decreases anteriorly to where the proximal end rapidly contracts to form a narrow neck; lateral margins slightly arcuate, or nearly straight, postero-lateral corners somewhat produced into broadly-rounded lobes. Abdomen tolerably elongated and equal to about two-thirds the length of the genital segment, a slight constriction near the posterior end giving it the appearance of an indistinct joint. Caudal rami short.

Antennules about two-thirds the length of the frontal plates. Antennæ rather slender. Second maxillipeds tolerably stout. Sternal fork robust with the rami somewhat expanded, widest in the middle and tapering slightly towards each end, also moderately far apart and scarcely divergent. Fourth pair of thoracic legs small, basal joint tolerably stout, and with the ramus composed of three joints, the outer distal angle of the first joint forming a blunt-pointed knob, that of the second joint bearing a small spine, the third armed with one short and two moderately long and spiniform apical setæ. Fifth pair minute. Length about $8.5 \mathrm{~mm}$. 
Male.-The male is only about half the size of the female. 'The carapace is somewhat elliptical in outline, rather longer than broad, and equal to about twothirds of the entire length of the animal; lateral margins evenly rounded. Genital segment suborbicular and equal to about one-third of the length of the carapace. Abdomen about half as long as the genital segment. Total length about $4 \mathrm{~mm}$.

Habitat.-Parasitic on the gills of turbot, Rhombus maximus (L.). North of Ireland (IT. T'hompson). Polperro, Cornwall (A. M. Norman). Plymouth (Bassett-Smith). Firths of Forth and Clyde, Aberdeen, \&c. (T. Scott). Irish Sea (A. Scott).

C. B. Wilson records Lepeoplitheirus thompsoni from La Jolla, California, U.S.A.*

[Lepeophtheirus obscurus Bassett-Smith.

As there is some ambiguity concerning this form, we quote the following remarks by A. M. Norman and T. Scott, in 'Crustacea of Devon and Cornwall,' p. 208: "Mr. Bassett-Smith ('Journ. Marine Biol. Assoc.,' vol. iv, 1896, p. 157) records a species from the brill (Rhombus lrovis) taken at Plymouth, and refers it with doubt to Lepeophtheirus obscurus Baird, which was obtained from the same species of fish. Subsequently Bassett-Smith figures what he then styles Caligus obscur'us Baird ("Ann. and Mag. Nat. Hist.,' ser. 6, vol. xviii, pl. iv, fig. 2), and not only is his parasite there referred to the genus Caligns, but the figures show the presence of sucking-disks. Whether the form he found was a Lepeophtheivus or a Caligus, it was certainly not Lepeophtheirus obscurus of Baird. In Bassett-Smith's third paper ('Proc. Zool. Soc.,' 1899, p. 456) he referred it back again to the genus Lepeophthein'us. It is just possible, if the species he found was a Lepeophtheirus, that it may have been the female of $L$. appendiculatus Kröyer ('Naturhist. 'Tidssk.', ser. 3, 1863, p. 207, pl. vi, fig. 4, a-i), which * 'Proc. U. S. National Museum,' vol. xxxv, p. 441 (1908). 
has a branched furcula, but the former was taken on the brill, while the latter was found on Raia clavata."

A Lepeophtheirus found on the brill by T. Scott, and doubtfully ascribed by him to L. obscurus Baird, seems to be merely a form of $L$. thompsoni, not deserving even varietal rank. Bassett-Smith's $L$. obscurus is probably similar, for in a copy of the 'Ann. and Mag.' paper referred to above kindly presented by the author, the lunulæ shown in figure 2, Plate 4, are deleted and the words "no lunulæ" are added at the side; so also the bifurcate appearance of the rami of the sternal fork shown in figure $\mathrm{F}$ on the same plate may likewise be due to an inadvertence.]

\section{Lepeophtheirus salmonis (Kröyer).}

(Plate XVII, fig. 4 ; Plate XVIII, figs. 11, 12.)

1837-38. Caligus salmonis Kröyer. (70) vol. i, pl. vi, fig. 7 a-c; vol. ii, pp. $13-18$.

1850. Lepeophtheirus stromii Baird. (4) p. 274. pl. xxxii, figs. 8, 9.

1863. Lepeophtheirus salmonis Kröyer. (71) p. 211, pl. xvii, figs. 1 a, $b$. 1900. Lepeophtheirus stromi T. Scott. (112) p. 152, pl. vi, figs. 3-8.

1905. Lepeophtheirus salmonis C. B. Wilson. (145) ps 640, pl. xxiv. figs. $294-300$.

Female.-Carapace rather longer than broad, and equal to about three-sevenths of the entire length of the animal, lateral margins slightly and evenly arcuate. Frontal plates not very clearly defined, the margin convex, and without lunulæ. Free thoracic segment very small. Genital segment tolerably large and of an oblong form, rather longer than broad, its length being about a third less than that of the carapace, the lateral margins only slightly arcuate but the posterolateral corners produced into rounded lobes, with the space between them deeply incurved. Abdomen narrow, elongated and unsegmented, and equal to about one-fourth of the entire length of the animal; distal end slightly constricted so as to have the appearance of an indistinct joint. Caudal rami very short.

Antennules rather small. Antennæ tolerably robust, and furnished with a moderately strong terminal hook. 
Maxillæ short and stout, and with the extremity distinctly bifurcated. Second maxillipeds robust and armed with short and stout terminal claws. Basal portion of the sternal fork short, the rami also short, somewhat expanded and bluntly rounded at the tip; slightly divergent and separated from each other by a comparatively wide semicircular space. The fourth pair of thoracic legs somewhat like those of Lepeophtheirus hippoglossi, but rather more robust, the first joint of the ramus, which is rather longer than the second or third, with the outer distal angle in the form of a blunt knob covered with microscopic bristles, the second joint provided with a short spine on the outer distal angle, and the third with three spiniform apical setæ, the inner one being the longest. Egg-strings very long and slender. Length 14-16 $\mathrm{mm}$.

Male.-The carapace of the male is rather longer than broad and more than half the entire length of the animal. Frontal plates narrow. Free thoracic segment of moderate size, its length rather less than the width. Genital segment ovate, longer than broad, and equal to about one-third of the length of the carapace. Abdomen rather narrower than the genital segment, and about a third shorter. Caudal rami about half as long as the abdomen.

The thoracic appendages are somewhat similar to those of the female, except that the second maxillipeds are proportionally stronger. Length $6-7 \mathrm{~mm}$.

Habitat.-Parasitic chiefly on salmon, Salmo salar, L., but it also occurs on one or two other species of the Salmonidæ. Berwick (Dr. Johnston). Ireland (W. Thompson). Polperro, Cornwall (A. M. Norman). Plymouth (Bassett-Smith). Scottish coasts (T'. Scott). Irish Sea (A. Scott).

This is one of the more widely distributed of the Caligidæ. It is recorded from the coasts of Alaska, Labrador, and from other parts of the North American sea-board, as well as from the coasts of Europe. The parasite does not appear to survive long after the fish enters the fresh water. The dorsal surface in this species has a curious metallic lustre different 
from most of the others of the same genus. Males appear to be comparatively scarce.

\section{Lepeophtheirus pollachii Bassett-Smith.}

\section{(Plate XVII, figs. 5, 6; Plate XVIII, figs. 13-15; Plate XLVIII, figs. 4, 5.)}

1896. Lepeophtheirus pollachius Bássett-Smith. (6) p.12, pl. iv, fig. 1. 1899. Lepeophtheirus pollachii idem. (8) p. 45...

1900. Lepeophtheirus pollachii T. Scott. (112) p. 153, pl. vi, figs. 9-13. 1905. Lepeophtheirus inominatus C. B. Wilson. (145) p. 656, pl. xxviii, figs. 345-352.

F'emale-Carapace oval, rather longer than broad, and equal to rather more than a third of the entire length of the animal, lateral margins slightly arcuate. Frontal plates not very prominent. Free thoracic segment small. Genital segment subquadrangular, length about a fourth less than the width at the proximal end, and a third less than the length and width of the carapace; widest posteriorly; the lateral margins nearly straight and the postero-lateral corner subangular. Abdomen fully as long as the genital segment, and indistinctly biarticulated, the end joint being rather narrower than the other. Caudal rami very small.

Antennules of moderate size. Antennæ with tolerably elongated, strong and abruptly hooked terminal claws. Second maxillipeds moderately short and robust, terminal claw stout and strongly curved. Sternal fork small, rami divergent, and bluntly rounded at the tips. Fourth pair of thoracic legs not reaching to the end of the genital segment; ramus somewhat slender and consisting of three subequal joints; the first and second joints each provided with a small spine on the outer distal angle, but the spine on the first joint sometimes wanting; the end joint furnished with three spiniform apical setæ of unequal length, the innermost being the longest. The entire length of the specimen represented by the drawing on Pl. XVII, fig. 5 , is $8 \mathrm{~mm}$. Egg-strings long and slender.

Mule.-The carapace of the male is equal to half the entire length of the animal. The genital segment is of 
an oval form, not much longer than, and about twice the width of, the following segments; its distal margin is rounded, with a minute setiferous plate on each side representing the fifth pair of legs. Abdomen composed of two subequal but indistinctly segmented joints. Length about $4.5 \mathrm{~mm}$.

Habitat.-Found for the most part on lythe, Gadus pollachius, adhering to the inside of the mouth, and rarely on other fishes. Plymouth (Bassett-Smith). Falmouth (A. M. Norman). On salmon captured at Polperro, Cornwall (Laughrin in 'Museum Normanianum'). Girvan, Firth of Clyde, and at Aberdeen FishMarket (T. Scott). Irish Sea (A. Scott).

This species does not appear to be so common as some of the others.

\section{Lepeophtheirus sturionis (Kröyer).}

(Plate XVIII, figs. 16-19; Plate XXI, fig. 1.)

1837. Caligus sturionis Kröyer. (70) pl. vi, fig. 6 .

1840. Lepeophtheirus sturionis M. Edwards. (43) vol. iii, p. 457.

1863. Lepeophtheirus sturionis Kröyer. (71) p. 139, pl. xvii, fig. 4.

1905. Lepeophtheirus sturionis T. Scott. (116) p.110, pl. v, figs. 7-14.

Female.-Carapace suborbicular and equal to about two-fifths of the entire length of the animal. Frontal plates not very prominent. Free thoracic segment not very clearly defined. Genital segment somewhat pyriform, widest posteriorly, becoming gradually narrower towards the front, then suddenly contracting to about the width of the free thoracic segment, length about equal to the width at the posterior end, and to about two-thirds of the length of the carapace; bluntly rounded at the postero-lateral corners. Abdomen tolerably elongated and narrow, being nearly three-fourths as long as the genital segment, slightly constricted near the distal end, the constriction forming a kind of false joint. Caudal rami very short and somewhat rudimentary.

Basal joint of the antennules tolerably expanded. Antennæ robust, and armed, with large and strong 
terminal claws, which have their ends bent at nearly a right angle to the basal part. Mandibles small, and resembling those of Lepeophtheirus pectoralis. Second maxillæ stout, and dividing at the apex into two slightly bent teeth. Second maxillipeds moderately stout and elongated, and armed with short but strong terminal claws. Sternal fork very stout, with short rami which are stout at the base and taper to a tolerably sharp point, the rami distinctly divergent. Fourth pair of thoracic legs robust, ramus moderately elongated and composed of three joints, the middle joint being rather longer than the first or third; the outer distal angle of the first joint terminating in a minute tooth, a tolerably stout spine springing from the outer distal angle of the second joint, the end joint armed with apical spiniform setæ of unequal length, the innermost being considerably longer than the other two, and the outermost the shortest. Length about $14 \mathrm{~mm}$.

We have not seen the male of this species.

Habitat.-Found as a parasite on the sturgeon, Acipenser sturio Linn. Obtained on a sturgeon captured about sixteen miles south-east of Aberdeen and landed at the Fish-Market there, 29th December 1904. We are indebted to Dr. Alexander Bowman for this specimen.

This species does not appear to be a very common one.

\section{Genus 8. LÜTKENIA Claus, 186 t.}

Syn. Cecropsina Heller, 1865.

Carapace obcordate, or nearly round, without frontal plates. Antennules two-jointed. Fourth ring of the thorax covered by small dorsal plates. Genital segment prolonged backwards in the form of lobes. Abdomen short, not jointed, and terminating in two small caudal plates.

The first pair of thoracic legs consisting of one or two branches, but the inner branch, when present, very small. The next three pairs two-branched. Both 
branches of the second and third pairs two-jointed, and of the fourth pair one-jointed.

\section{Lütkenia asterodermi Claus.}

\section{(Plate XIX, figs. 1-9; Plate XXIII, fig. 4.)}

1864. Lütkenia asterodermi Claus. (33) p. 365-383, pl. xxxiv.

1865. Cecropsina glabra Hellex. (58) p. 209, pl. xix, figs. 1, 2.

1906. Lütkenia asterodermi Norman \& T. Scott. (88) p. 210, pl. xx, figs. 9,$10 ;$ pl. xxiv, figs. 1-8.

1906. Lütkenia asterodermi A. Brian. (21) p. 48.

Female.-Carapace suborbicular or obcordate, with the posterior margin deeply hollowed out. Last thoracic segment produced into a leaf-like bifurcated dorsal expansion, the distal end forming two rounded lobes which are separated by a tolerably deep and narrow sinus; the width of the plate at the proximal end equal to about two-thirds the width of the carapace; the anterior portion of the outer margin sloping in a slightly arcuate line from the middle towards the front corners which are distinctly angular. Genital segment produced backwards into two contiguous lobes which completely overhang and conceal the abdomen and caudal rami, so that they can only be seen from the ventral aspect.

Abdomen somewhat lozenge-shaped, broader than long, the length being three-fifths the width. Caudal rami nearly contiguous, broadly lamelliform and scarcely half as long as the abdomen.

Antennules very small, second joint slender and nearly as long as the first. Antennæ armed with strong hook-like terminal claws. First maxillipeds slender and furnished with terminal claws, two of which are small and subequal and the others rather longer and stouter. Second maxillipeds large, basal joint stout with one or two nodulous processes on the inner aspect, the terminal claw large, strong, and sickle-shaped. First pair of thoracic legs small, biramose, inner ramus minute, simple, and not half the length of the first joint of the outer ramus. The outer ramus two-jointed, the end joint very small, its distal 
end truncated and provided with three or four minute apical spines. In the second and third pairs both rami two-jointed; the first joint of the outer ramus considerably larger than the second; in the inner ramus the first joint is the smaller one. In the fourth pair, also biramose, both rami only one-jointed, the inner ramus being very minute.

Habitat.-Parasitic on Luvarus imperialis Raf. Three specimens of this Irittenia were sent to the Rev. A. M. Norman by Laughrin about 1863, which had been obtained by him from a specimen of Luvarus captured off Polperro, Cornwall. ('Crustacea of Devon and Cornwall,' by Norman and 'T. Scott, 1906, p. 210.) Distribution.-Mediterranean ; apparently very rare in the British Seas.

\section{Genus NOGAUS Leach, 1819.*}

Syn. Nogagus M. Edwards, 1840.

The genus Nogaus is now generally regarded as unsatisfactory. It comprises males ouly, some of which have already been recognized as belonging to more than one genus, of which the females had previously only been known; and it is considered probable that as our knowledge of the Copepod parasites of fishes increases and their relationships and life-history are better understood, all the males ascribed to Nogaus will ere long be removed from it and the genus itself become obsolete. There are however, a few of the Nogaus males whose relationship is still doubtful, and it will be better to leave these where they are till they can be disposed of satisfactorily. Among these doubtful forms is the one described below.

In Nogaus the frontal plates are without Iunulæ, but otherwise the forms ascribed to this genus have a general resemblance to Caligus. Steenstrup and Lütken divided Nogaus (or Nogagus) into two groups, the principal differences between them being as follow. In species belonging to the first group the four pairs of swimming legs are biramose, and the rami are all two-jointed; the abdomen also is two-jointed. In those belonging to the second group, while the rami of the

* The name "Nogaus" was used by Dr. Leach in 1819 ; it was afterwards changed to Nogagus by M.Edwards in 1840, but we find Dr. Baird still using the original word "Nogaus" in his 'British Entomostraca' at p. 282; and C. B. Wilson in his recent work on 'North American parasitic Copepods of Fishes' also adopts this form of the name. 
first three pairs are two-jointed, the fourth has only onejointed rami, and the abdomen consists of a single segment. The form described below differs from both these groups, but partakes to some extent of the characters of both.

\section{Nogaus ambiguus T. Scott. (Provisional name.)}

$$
\text { (Plate XX, figs. 1-8.) }
$$

1907. Nogagus ambiguus 'T. Scott. (117) Twenty-fifth Annual Report of the Fishery Board for Scotland, Part III, p. 217, pl. xv, figs. 10-17 ( $\delta$ ).

The cephalic shield in this form is of an oval ontline, the front is somewhat narrowly rounded but the frontal plates are moderately large. The last two thoracic segments are subequal, their width is about one-third of that of the cephalic shield at its widest part, and the last segment is truncated behind. The abdomen consists of a single small subtriangular segment blunt-pointed at the apex; and the caudal rami, which are short but moderately wide, are furnished with tolerably long plumose setæ.

The antennules, which are of average size, are provided with long plumose hairs. 'The antenur, mandibles, and maxillæe are of the usual Caligus type. 'The first maxillipeds are elongated, and are each armed with a long and powerful terminal claw which has a moderately stout seta at its base, nearly as in Nogaus lunatus (Stp. \& Lütk.), a species which the present form resembles in some other particulars. The second maxillipeds are short and very stout, and are each fitted with a stout claw which forms, with the tuberculated palm, a strong grasping organ. All the four pairs of swimming legs are short and biramose; in the first three pairs both the outer and inner ramus are tro-jointed and of nearly equal length, and the end joints of both rami bear tolerably long, densely plumose setæ round the inner margin and end; there are also a few short spines on the outer margin. The fourth pair are rather small, the inner ramus is biarticulate as in the other three pairs, but the outer ramus is composed of a single, somewhat club-shaped joint with three long plumose setæ round the distal end of the inner margin, and with four spines-three small ones and a moderately large terminal spine-on the exterior edge. Length about $5.5 \mathrm{~mm}$.

Habitat.-Parasitic on a piked dog-fish, Squalus acanthias, captured in the North Sea in 1902.

This form has a somewhat close resemblance to $N$. lunutus: described by Steenstrup and Lütken ('Bidrag til Kundskab,' p. 389, pl. ix, fig. 17, 1861). 


\section{Genus 9. DEMOLEuS Heller, 1865.}

\section{Syn. Caligus Otto (not O. F. Müller).}

Carapace suborbicular, divided into three parts by two longitudinal sutures, middle portion subquadrate, lateral portions narrow, produced backwards into prominent rounded lobes. Frontal plates distinct, without lunulæ. Eyes conspicuous, close together. First and second free thoracic segments small; the next larger and prolonged backwards so as to form small dorsal plates in the female but which are wanting in the male. Genital segment elongated in the female, subquadrate in the male. Abdomen short, not jointed, covered dorsally with a foliaceous lamina. Caudal appendages large.

\section{Demoleus paradoxus (Otto).}

\section{(Plate XII, figs. 4, 5.)}

1828. Caligus paradoxus Otto. (93) p. 352 , pl. xxii, fig. 5 .

1861. Nogagus grandis Steenstrup \& Lütken. (127) p. 386, pl. x, fig. 19.

1865. Demoleus paradoxus Heller. (58) p. 199, pl. 19, fig. 3.

Female.-Carapace suborbicular and equal to about a third of the entire length of the animal ; frontal plates distinct, lunulæ wanting, postero-lateral lobes considerably produced behind. First and second free thoracic segments small, and just filling the space between the produced lateral lobes of the carapace; the first segment with, and the second segment without, lateral processes. The next segment less than half the width of the other two and furnished with two small dorsal plates. Genital segment elongated, length equal to fully twice the width, and divided posteriorly by a deep median sinus ințo two lobes which are rounded at the end. Abdomen very small, triangular, not seen from the dorsal aspect. Caudal rami large, extending beyond the end of the genital segment and bearing a few minute spiniform setæ.

Antennules two-jointed, partly concealed by the 
frontal plates; antennæ small with weak terminal claws. The terminal claws of the second maxillipeds of moderate size. The first four pairs of thoracic leg's all biramose, and the rami biarticulated and furnished with plumose setæ, the first and fourth pairs with very small basal joints, those of the second and third considerably expanded. Egg-strings very long and slender, and looped so as to appear as if they each consisted of three strands.

Male.-The male, which is of the usual Nogaus form, is somewhat similar to the female, but the suborbicular carapace is proportionally larger, being equal to at least three-sevenths of the total length. The first free thoracic segment fills the space between the lateral prolongations of the carapace, and is slightly produced into small rounded lobes which are contiguous with the lobes of the carapace. The next segment is small, while the third (the fourth counting the carapace) is without dorsal plates. Genital segment oblong, rather longer than broad, width equal to fully one-third the width of the carapace, and having the postero-lateral corners slightly produced and rounded. Abdomen small, two-jointed ; caudal rami large and lamelliform, longer than broad and furnished with small spiniform setæ on their truncated distal extremities. Cephalic appendages somewhat like those of the female, but the second maxillipeds are short and tolerably stout, bearing stout terminal claws; the thoracic legs are also similar to those of the female. Length variable, about 13 to $16.5 \mathrm{~mm}$.

Habitat.-Parasitic on dog-fishes. On a dog-fish captured off the North of Ireland. Belfast Bay ( $\mathrm{W}$. Thompsom, ' Nat. Hist. of Ireland,' vol. iv, 1856).

We have not seen this species. Our figure of it is reproduced from that of Otto referred to above.

C. B. Wilson, after a critical examination of the characters of Nogagus grandis Steenstrup and Lütken, remarks it is "fairly certain" that this Nogagus is the male of Demoleus paradoxus (Otto). 


\section{Genus 10. TREBIUS Kröyer, 1838.}

Resembling Lepeophtheivus in its general form and in the absence of lunulæ, and also generally in the structure of the body and its appendages, except that the fourth pair of thoracic legs are biramose in both the male and female. The second maxillæ tolerably long with the extremity pointed or slightly bifurcated. The first maxillipeds rather stronger than in Lepeophtheirus or Caligus, but the second pair less powerful than those of the two genera mentioned.

Several species of Trebius have been described, but the one recorded below is the only species represented in the British fauma.

\section{Trebius caudatus Kröyer.}

(Plate XXII, figs. 1, 2 ; Plate LIV, figs. 1-11.)

1838. Trebius caudatus Kröyer. (70) p. 30, pl. i, fig. 4 .

1850. Trebius caudatus Baird. (4) p. 280 , pl. xxxiii, fig. 3.

1900. Trebius caudatus T. Scott. (112) p. 155, pl. vi, figs. 20-26.

1907. Trebius caudatus C. B. Wilson. (147) p. 681. pl. xv, figs. 11-13; pl. xvi, figs. 14-22.

Female. - Carapace suborbicular, rather longer than broad, and equal to about a third of the entire length of the animal. Frontal plates narrow, without lunulæ. Eyes conspicuous and close together. Free thoracic segment small. Genital segment oblong, rather longer than broad, its width equal to about three-fourths of the length, and to about two-thirds the width of the carapace, the lateral margins nearly straight, its posterior end truncated, and the posterolateral corners rounded and provided with three small but stout marginal spines. Abclomen elongated, narrow, and composed of three segments, its length about equal to that of the carapace, the proximal joint longest, being rather more elongated than the next two combined; the second about twice the length of the third joint, the articulation between the second and third joints not very clearly defined. Caudal rami short and furnished with a fer plumose apical setr. 
Antennules small. Antennæ armed with strong terminal hooks. Mandibles similar to those of Lepeophtheirus but the end joint somewhat stouter and more distinctly toothed. Second maxillæ with the endopodite slightly bifurcate. Second maxillipeds tolerably elongated, not very robust and provided with rather weak terminal claws. Sternal fork small, with the rami simple, short, and slightly divergent. The four pairs of thoracic legs all biramose; the first pair with both rami two-jointed, but the rami of the other three pairs composed of three joints; the basal joint of the fourth pair short and tolerably expanded, the rami also short and of nearly equal length, the inner being rather the shorter, both rami with the inner margins fringed with tolerably long plumose setæ. Fifth pair nearly obsolete. Length about $10 \mathrm{~mm}$.

Male.-Carapace orbicular and equal to about half the entire length. Genital segment small, ovate, somewhat longer but not much wider than the free thoracic segment. Abdomen biarticulate, narrow, and about as long as the genital segment; proximal joint rather shorter than the end one. Length about $4.5 \mathrm{~mm}$.

Habitat.-Parasitic on skates, rays, dogfishes, \&c. Belfast (W. Thompson). Polperro, Cornwall (A. M. Norman). Plymouth (Bassett-Smith). Irish Sea (A. Scott). Firths of Forth and Clyde and at Aberdeen $(T$. $S$ cott).

Not very rare. The distribution of Trebius caudatus. appears to be somewhat limited; it is mentioned by C. B. Wilson in his 'North American parasitic Copepods,' but the specimens, he states, were collected off the coast of Shetland.

\section{Genus 11. ELYTROPHORA Gerstaecler, 1853.}

Female-Carapace rounded, frontal plates distinct but without lunulæ. First three thoracic segments fused with the head; fourth segment with two dorsal plates. Genital segment lobed posteriorly. Abdomen 
two-jointed, joints subequal, without wings. Caudal rami tolerably large. Antennules two - jointed. Antennæ uncinate. Mouth-organs somewhat similar to those of Caligus. Thoracic legs, four pairs, all biramose. In the first pair both rami two-jointed; both rami of the second and third pairs three-jointed, but in the fourth pair, while the outer ramus is three, the inner is only two-jointed.

Male.-Somewhat similar to the female, but rather smaller.

\section{Elytrophora brachyptera Gerstaecker.}

(Plate XIX, fig. 10; Plate XXIII, figs. 1, 2; Plate XXXI, figs. 1-6.)

1853. Elytrophora brachyptera Gerst. (48) p. 60, pl. iii, figs. 1-14.

1863. Arnæus thynni Kröyer. (71) p. 157, pl. viii, fig. 5 a-g.

1865. Elytrophora brachyptera Heller. (58) p. 189, pl. xvii.

1896. Elytrophora brachyptera Bassett-Smith. (6) p. 12, pl. iv, fig. 3.

Female.-Carapace orbicular, scarcely equal to half the entire length of the animal, or as 5 to 11. Frontal plates distinct, without lunulæ. The fourth thoracic segment carrying two small dorsal plates which are somewhat widely apart in front, but gradually approach each other behind; their outer margins incurved, and the posterior margins, which are rounded, slightly overlapping the anterior edge of the genital segment. Genital segment ovate and moderately tumid, nearly half as wide as the carapace and about one and a half times longer than broad, the lateral margins slightly arcuate, and the posterolateral corners produced into short rounded lobes. Abdomen biarticulate, narrower than the genital segment, first joint with the postero-lateral corners somewhat produced and rounded, anal segment suborbicular with a minute posterior lobe in the median line ; caudal rami obovate, expanded towards the distal end, and bearing four or five apical plumose setæ.

Antennules small. Antennæ strongly uncinate. Mandible and maxillæ somewhat like those in Trebius. 
Second maxillipeds armed with strong terminal claws. Thoracic legs four pairs, all biramose; both rami of the first pair two-jointed, the outer ramus tolerably elongated, but the inner very small; both rami of the second and third pairs composed of three joints, but in the second the rami are nearly of equal length, with the end joints very small, while in the third the outer ramus is distinctly shorter than the inner. These three pairs of thoracic legs all liberally supplied with densely plumose setæ. In the fourth pair the outer ramus stout, and composed of sub-equal joints, both the first and second joints having a strong and slightly-curved spine on their outer distal angle, while the end joint has three similar spines on its outer margin, and three or four small ones on the inner margin; the inner ramus, which is situated close behind the outer, small, and composed of two subequal joints; the basal joint of the fourth pair also tolerably large, and gibbous below. Length about $11.5 \mathrm{~mm}$.

Male.-The male, though somewhat similar to the female in its general appearance, is smaller, and the second maxillipeds are more powerfully clawed; and while the genital segment is only about half as large, the abdomen is rather longer than in the female. 'The postero-lateral corners of the penultimate segment of the abdomen are angular, while the anal segment has a subquadriform outline. 'The caudal rami are furnished with four setæ longer and more densely plumose than in the female. Length about $9 \mathrm{~mm}$.

Habitat.-Parasitic on the tunny, Orcymus thynnus, Plymouth (Bassett-Smith). Outer Hebrides (Di. Alex. Bowman). We are indebted to Dr. Bowman for specimens of this interesting species.

Distribution.-European seas.

The species is not an uncommon one on the tunny. 


\section{Genus 12. DINEMOURA Latreille, 1829.}

Syn. Dinematura Burmeister, 1833.

Female.-Carapace suborbicular, deeply excavated posteriorly; frontal plates narrow. The first free segment of the thorax with small lateral lobes; the next segment narrow with or without rudimentary dorsal plates; the third segment with dorsal plates of tolerable size, separated by a narrow median fissure, and overlapping the anterior portion of the genital segment. The genital segment of an oblong form and with the postero-lateral corners produced into short, broadly-rounded lobes. Abdomen small and uniarticulate; caudal rami tolerably large and foliaceous. Between the genital segment and the abdomen there is a very small joint with two dorsal plates and furnished below with a pair of rudimentary legs.*

Antennæ short and moderately stout, and armed with strong hooked terminal claws. Mandibles long and very slender, and provided with a few minute teeth near the tip. Second maxillæ slender, threejointed; first maxillipeds also slender, and furnished, each, with an apical claw and two small lateral processes. Second maxillipeds moderately stout. Swimming-legs all biramose; first pair with both rami two-jointed; those of the second and third pairs three-jointed, while in the fourth pair both rami consist of tolerably large one-jointed foliaceous plates.

Male.-Carapace proportionally wider than in the female. Second free thoracic segment without dorsal plates. The dorsal plates of the third segment small and overlapping only a small portion of the genital segment. Genital segment cuneiform, wider towards the distal end. Abdomen very narrow, biarticulate; caudal rami large. Swimming-legs biramose, both

* C. B. Wilson appears to be the first to give an accurate description of this part of the animal which he names the sixth segment. $C f$. 'North American Parasitic Copepoda,' 'Proc. U. S. National Museum,' vol. xxxiii, pp. 374, 376 (1907). 
rami of the first and fourth pairs composed of two joints, and those of the second and third pairs of three joints; the rami of the first three pairs are furnished with tolerably long plumose setæ while those of the fourth pair are armed with spines.

The only British species is that described below.

\section{Dinemoura producta (O. F. Miller).}

(Plate XXII, fig. 3; Plate XXVI, figs. 1-3; Plate XXVII, figs. 1-8.)

1785. Caligus productus O. F. Müller. (86) p. 132, pl. 21, fig. 3.

1829. Dinemoura producta Latr. (38) Cuv. Règne Ánim., vol. iv, p. 127. 1835. Pandarus lamnæ Johnston. (65) p. 203.

1850. Dinemoura lamnæ Baird. (4) p. 286, pl. xxxiii, fig. 7.

1853. Nogagus productus Gerst. (48) Wiegmann's Archiv für Naturgesch., vol. xix, p. 63, pl. iv, figs. 1-10.

1857. Dinematura elongata P. J. van Beneden. (14a) Bull. Acad. Roy. Belg., p. 231, pl. xxiv.

1861. Dinematura producta Stp. \& Lütk. (127) p. 34, pl. vii, fig. 13. 1900. Dinematura producta T. Scott. (112) p. 156, pl. vi, figs. 27-31. 1907. Dinematura producta C. B. Wilson. (148) p. 380, pl. xxiii.

Female-Carapace suborbicular and equal to about a third of the entire length of the animal; width slightly exceeding the length; lateral margins boldly rounded; frontal plates narrow; eyes small, but quite distinct, not quite close together and distant from the front margin about a tenth part of the total length. The first free thoracic segment furnished with small lateral plates which inclose the next segment between them, these two segments together filling the entire space between the produced postero-lateral lobes of the carapace. The third segment of the thorax carrying a dorsal plate which is equal to about one-sixth of the entire length of the animal and is as wide as the genital segment the anterior part of which it overlaps; the antero-lateral corners of the plate subangular, and also divided from behind forward into two lobes by a narrow median fissure which extends to near its base, each lobe being boldly rounded at the posterior end. Genital segment oblong, considerably longer 
than the segment last described and equal to nearly two-thirds of the width of the carapace; the posterolateral corners of the segment produced backwards into moderately narrow lobes with rounded ends and having a space between them equal to about the width of one of the lobes; a shallow median groove also extending along nearly the whole length of the segments as indicated in the drawing (Pl. XXII, fig. 3). The space between the lobes occupied by a small plate provided with two slightly divergent appendages which scarcely reach to the end of the abdomen. Abdominal segment small, subquadrangular, concealed in dorsal view. Caudal rami in the form of broad foliaceous plates rather longer than broad, and having one marginal, and three short, tolerably stout, spiniform setæ. There is also a small segment, intermediate between the genital segment and abdomen, which is provided with lateral uniarticulate and somewhat rudimentary appendages, but this segment is seen only from the ventral aspect.

Antennules small. Antennæ short and stout and armed with strongly-hooked terminal claws. Mandibles elongated and extremely slender, with a few minute marginal setæ near the tip. First maxillipeds each furnished with a terminal and tolerably elongated hook-like appendage and one or two short accessory processes. Second maxillipeds short and stout, but somewhat rudimentary in structure. Swimming-legs all biramose; both rami in the first pair two-jointed, the first joint of the outer ramus considerably expanded, and its outer distal angle reaching forward to the middle of the short end joint and terminating in a short stout spine; the inner ramus very small and the joints subequal. The fourth pair large and foliaceous, each ramus about twice as long as broad, and furnished with a few minute spines round the distal end. Length exclusive of egg-strings about $20 \mathrm{~mm}$.; egg-strings alone sometimes reaching to $80 \mathrm{~mm}$.

We have not seen the male of this species. 
Habitat.-Parasitic usually on the porbeagle shark, Lamna cornubica. Berwick Bay, 1834 (Dr. Johnston). Polperro, Cornwall (A. M. Norman). Moray Firthoff Dunrobin, and at Aberdeen Fish-Market (T. Scott). Near Shetland (C.B. Wilson). On a thrasher shark, Alopias vulpes, at Buddon, Firth of Tay, in 1887 (Prof. d'Arcy W. Thompson). Recorded also from the Greenland shark, Scymnus glacialis.

Distribution.-European waters. Atlantic coast of North America.

Genus 13. ECHTHROGALEUS Steenst»up of Lütlien, 1861.

F'emale-Carapace, antennæ, and mouth-appendages nearly as in Phyllorthragoriscus, but the dorsal plates of the last thoracic segment larger. The genital segment, which is also large, extending backwards so as to overlap and conceal wholly or partially the abdominal segment and caudal rami; the posterolateral lobes of the genital segments rounded at the end and separated by a tolerably deep sinus which may be narrow as in $E$. coleoptratus or moderately wide as in $E$. denticulatus.

Thoracic limbs as in Phyllorthragoriscus except that the inner ramus of the second and third pairs are composed of two instead of three articulations.

"Male.-Carapace like that of the female but proportionately larger, frontal plates more prominent. Lateral lobes of second thoracic segment corresponding to the first pair of dorsal plates in the female; no lobes on the third segment; a rudimentary pair on the fourth segment which are closely appressed to the anterior margin of the genital segment. The latter smaller than in the female, with one pair of legs at or just in front of the posterior corners. Abdomen small and two-jointed; anal lamina large and armed with plumose setæ. Appendages as in the female." (C. B. Wilson.) 


\section{Echthrogaleus coleoptratus (Guérin).$$
\text { (Plate XXII, fig. 4.) }
$$

1829-1843. Dinematura coleoptrata Guérin. (55) pl. xxxv, fig. 6. (1840). 1835. Pandarus alatus ("M. Edwards") Johnston. (66) p. 202, two text-figs.

1850. Dinemoura alata Baird. (4) p. 285 , pl. xxxiii, figs. 8,9 .

1861. Echthrogaleus coleoptratus Stp. \& Ltk. (127) p. 380, pl. viii, fig. 15 .

1900. Echthrogaleus coleoptratus T. Scott. (112) p. 156, pl. vi, fig. 52.

1907. Echthrogaleus coleoptratus C. B. Wilson. (148) p. 367, pl. xix.

1910. Echthrogaleus coleoptratus T. R. R. Stebbing. (125) p. 559.

Female.-Body oblong, fully twice as long as broad. Carapace suborbicular and equal to about a third of the entire length of the animal; frontal plates tolerably large and distinct. First two thoracic segments short and narrower than the carapace; dorsal expansion not greatly developed. Dorsal plates of the third segment much enlarged, wider behind than in front, and covering rather less than half the genital segment, their posterior margins obliquely and sinuately truncated so that the inner corners extend further backward than the outer, and though the inner margins of the plates come close together in the middle line they do not overlap, their margins being even, not serrated, and their surface smooth and ornamented with a number of small pellucid impressed circular markings arranged in a more or less regular pattern, which, along with the form of the plates, gives them a fairly close resemblance to the elytra of certain coleopterous insects. Genital segment tolerably large, extending. backwards considerably beyond the dorsal plates described above, becoming somewhat narrower posteriorly and being divided into two lobes by a narrow and deep median cleft or sinus; the inner edges of the lobes closely appressed and not overlapping, and their posterior margins rounded and reaching to about the end of the caudal rami; the abdomen, which is concealed in dorsal view by the genital segment, comparatively small and sub-quadriform in outline, the width being somewhat greater than the length ; caudal 
rami lamelliform, broadly ovate, the ends subtruncate, scarcely extending beyond the genital segment, and provided with a few apical spinules. Intermediate between the genital segment and abdomen is a small rounded plate concealed in dorsal view.

Antennules rather slender, not prominent; antennæ furnished with strong, hooked, terminal claws. Mouthtube moderately short and slender. Second maxillipeds short, moderately stout, and furnished with powerful terminal claws. Other mouth-organs as in Dinemoura. Swimming-legs short and biramous; first and second pairs with both rami two-jointed; third pair with the outer ramus composed of three and the inner of two joints; while in the fourth pair both rami consist of a single foliaceous joint. The fifth pair of thoracic legs represented by a small spine-like process on the under side and near the posterior end of the genital lobes.

Length 11 to $13 \mathrm{~mm}$. Egg-strings long and slender. Habitat.-Found parasitic on the porbeagle shark, Lamna cormulica. Berwick Bay (Dr. Johnston). Aberdeen Fish-Market and near Fair Island between Orkney and Shetland (T'. Scott). From both the porbeagle and the blue shark, Carcharias glaucus, taken at Polperro, Cornwall (A. M. Norman).

The distribution of this Echthrogaleus is extensive and includes the seas of Europe, the Atlantic and Pacific coasts of North America, and the coast of South Africa.

\section{Echthrogaleus lütkeni (Norman).}

(Plate XXIX. fig. 1; Plate XXX, figs. 1-8.)

1869. Nogagus lü.tkeni Norman. Last Rept. on Dredging among the Shetland Isles; Brit. Assoc. Rept. for 1868, p. 300.

1906. Echthrogaleus liutlieni Norman \& T. Scott. (88) p. 213, pl. xxii, figs. 1-9.

In the "Last Report on Dredging among the Shetland Isles," the Rev. A. M. Norman records and describes a fish parasite under the name of Nogagus lïtleni. The specimen, which was procured by Dr. Saxby, was found on a skate. Two other specimens 
were subsequently obtained at Polperro in Cornwall, but the name of the fish on which they occurred has not been recorded. All these specimens were males. In dealing with this group of fish parasites it is sometimes difficult, if males only are available, to determine the species to which the specimens belong; a careful study, however, of the examples referred to, leaves little doubt that they are the males of an Echthrogaleus.

The following is the description of E. lütieni as given in 'Crustacea of Devon and Cornwall':"The cephalosome is much rounded, its breadth much greater than the length; the hinder corners of the lateral area incurved, well rounded, and reaching backwards to the end of the first of the two exposed segments of the metasome. First segments of metasome with lateral expansions broader and longer than in the following short segment. The urosome consists of three segments; the first, or genital segment, is subquadrate with slightly arched sides, longer than broad; the second segment very short, the terminal rather broader than long; the uropodal laminæ are as long as the two preceding joints, and of an orate form.

"The antennules have the first joint much longer than the second; the second joint has one spine on the hinder margin. The antennæ have the penultimate joint stout, the last long and gradually attenuated, only very slightly curved, bearing a single seta on the inner face. The first maxillipeds have the claws setose. The second maxillipeds have the terminal joint very broad and stout, obliquely truncate distally, with a nodule, and areolated disk at the commencement of the palm; the finger short and stout. The first feet have both rami composed of two joints; the inner branch terminates in three setæ, the outer in four ; the first joint of this outer branch has one spine on the outer margin, and the second joint three. The second, third, and fourth feet are alike in general character, though differing slightly in the number of 
setæ and external marginal spines. The fifth feet, which are situated under the genital segment, are minute, one-jointed, bearing two or three short setæ.

"Polperro, two specimens, but the record of the fish on which they were found was not given. The type specimen was taken on a skate at Shetland." (See pp. 213-214.)

Our figure of the species is reproduced from that in the work referred to. We have not, ourselves, obtained this parasite.

\section{Genus 14. PHYLLOTHREUS Norman, 1903.}

Syn. Phyllophora M. Edw. (name preoccupied).

Body depressed. Carapace broadly cordate, without frontal plates. Thorax furnished with three pairs of broadly-rounded overlapping laminæ, which extend considerably on either side of the carapace. Abdominal region two-segmented; genital segment tolerably short and broad; distal segment small, rounded, and provided with short lateral processes.

Antennules small. Antennæ assuming the form of large hooks which project in front of the carapace. All the thoracic legs biramose and lamelliform. Eggstrings slender and elongated.

The name Phyllophora employed by M. Edwards for this genus was preoccupied by Thunberg in 1812 (for a genus of Orthoptera), and by Gray in 1838.

\section{Phyllothreus cornutus (M. Edwards).}

\section{(Plate XIX, figs. 11-18; Plate XXIII, fig. 3.)}

1840. Phyllophora cornuta M. Edw. "(43) p. 471, pl. xxxviii, figs. 13, 14. 1899. Phyllophorus cornutus Bassett-Smith. (8) p. 465.

1903. Phyllothreus cormutus Norman. (87) Ann. and Mag. Nat. Hist. (7), vol. xi, p. 368 (April).

1906. Phyllothreus cornutus Norman \& T. Scott. (88) p. 212, pl. xxiv. figs. $9-17$.

Female-Carapace subcordate, wider posteriorly, greatest width equal to about one and one-third times the length, lateral margins slightly arcuate, converging. 
towards the front which is truncated and without frontal plates; posterior edge deeply emarginate, and with the lateral corners rounded. Thorax provided with three pairs of leaf-like and suborbicular overlapping plates, which extend on each side to considerably beyond the margin of the carapace and reach backwards to a distance equal to the length of it. Abdominal region distinctly narrower than the carapace and composed of two segments; the genital segment suborbicular, its length being rather less than the width, and bearing, at the corners of the truncated hinder margin, ovate processes which represent the fifth pair of feet; the last segment consisting of two small transversely-obovate plates from between which issue the two slender and elongated egg-strings.

Antennules small, two-jointed, end joint narrow, much shorter than the proximal one, and bearing a few apical setæ and a minute spine near the middle of the lower margin; the antennæ are represented by large hooks which project considerably in front of the carapace and form powerful grasping organs. First maxillipeds with the end joint narrow and provided with three terminal spines, the middle one being the largest, tips of all three slightly hooked; second maxillipeds cheliform. Thoracic legs short, biramous, and more or less lamelliform; first pair with outer ramus one-jointed and slightly geniculated, and the inner two-jointed; second pair with both rami twojointed; while in the third and fourth pairs both rami are uniarticulate. All the rami are devoid of setæ and bear only a few small spines. Length about $13 \mathrm{~mm}$. Male unknown.

Habitat.-Parasitic on the blue shark, Carcharius glaucus. Two specimens were collected by William Laughrin at Polperro, Cornwall, many years ago, and were sent by him to the Rev. Canon A. M. Norman. "The only other previously known habitat of the species was, according to Milne Edwards, Tongatabu in the Friendly Islands, whence the type specimens 
came; this is therefore a remarkable instance of wide distribution" (A. M. Norman).

We are greatly indebted to Canon Norman for the privilege of examining the specimens referred to, and for permitting us to reproduce the figure of it published in 'Crustacea of Devon and Cornwall.'

\section{Genus 15. PANDARUS Leach, 1816.}

Female.-Body moderately broad and elongate. Carapace ovate, wider behind than in front; frontal plates of moderate size; posterior margin not very deeply excavated. Thorax provided with three pairs of dorsal plates, the first pair lateral and of an elongate-ovate form, the second pair between them in the form of broadly-rounded lobes separated from each other by a moderately deep median sinus; the third pair nearly as wide as the carapace and prolonged backwards so as to cover a considerable portion of the genital segment; the dorsal plates of the genital segment with the inner lateral margins contiguous and apparently coalescent, and produced posteriorly into rounded or angular lobes having between them a flattened suborbicular median plate concealing the abdomen.

Antennules biarticulate and provided with an adhesive disk at the base. Antennæ armed with terminal claw-like hooks, and also furnished with adhesive disks or pads somewhat similar to those at the base of the antennules and maxillipeds. 'Thoracic legs biramose ; rami of the first three pairs biarticulate, the outer ramus of the first pair more or less abnormal in form and the joints sometimes coalescent; in the fourth pair the rami consisting of a single joint. Caudal rami subtriangular and divaricate, usually seen projecting-one on each side-beyond the plate at the end of the genital segment.

Male.-The male has a close general resemblance to the male of Lepeophtheirus, the antennules, which are provided with adhesive disks as in the female, differ in 
being armed with terminal claws; the maxillipeds are also furnished with small terminal but distinct clawlike hooks. The other mouth-appendages are somewhat similar to those of the female. All the four pairs of thoracic legs are biramose, with biarticulate rami, and they differ from those of the female in being provided with moderately long and densely plumose setæ.

\section{Pandarus bicolor Leach.}

(Plate XXI, fig. 2; Plate XXII, figs. 5-6; Plate XXVI, figs. 4-19 ; Plate LVIII, figs. 1-8.)

1816. Pandarus bicolor and boscii Leach. (74) pp. 405, 406, pl. xx, figs. 1 and 2 and figs. 1-10.

1840. Pandarus fissifrons M. Edwards. (43) p. 470.

1850. Pandarus bicolor and boscii Baird. (4) pp. 288, 289, p]. xxxiii, fig. 6 .

(?) 1854. Nogagus angustulus Gerst. (ठ̋). (48) p. 193, pl. vii, figs. 17 and $18\left(\sigma^{\top}\right)$.

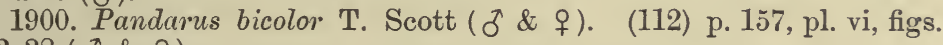
33-38 (oे \& q).

1907. Pandarus bicolor C. B. Wilson. (148) p. 400, pl. xxvii.

1907. Nogagus latus T. Scott. (117) p. 216, pl. xv, figs. 1-9 (ठَ, immature).

Female.-Body oblong, width equal to rather more than a third of the entire length. Carapace widest posteriorly, lateral margins slightly arcuate, converging towards the front, anterior margin with a small median notch, frontal plates tolerably distinct, posterolateral corners not greatly produced. Thorax provided with three pairs of dorsal plates ; first pair lateral and of an ovate form and inclosing the second pair between them; the second pair terminating in broadly-rounded lobes which scarcely reach beyond the ends of the first, the combined width of the two pairs being nearly equal to that of the carapace; the posterior margins of the two pairs of plates are nearly in a straight line and have the appearance of four subequal lobes; the third pair about as wide as the carapace and prolonged backward to near the middle of the genital segment, separated posteriorly by a moderately deep median sinus and terminating in two broadly-rounded 
lobes. Dorsal plates of the genital segment considerably produced, their inner margins contiguous and coalescent; posterior corners prolonged into rounded lobes, the space between the lobes being filled by a suborbicular lamina which entirely conceals the abdomen, while the caudal rami are seen projecting one on each side of the median plate in the form of a triangular process.

Antennules small, partly concealed by the frontal plates; antennæ also small, terminal claws slender with an accessory spine on the inner margin. Adhesion-disks four pairs. First maxillipeds slender, joints subequal, terminal claws unequal; second maxillipeds considerably dilated. Thoracic legs biramose ; the inner ramus in the first pair biarticulate, the end joint being longer than the proximal one, and with the apex broadly rounded and bearing a few setæ on the lower half of the inner margin; outer branch longer than the inner and composed of two partly or wholly coalescent joints, the proximal part being distinctly wider than the distal portion, which is abruptly geniculated and tapers towards the apex ; second and third pairs with both rami two-jointed; while in the fourth pair each ramus is composed of a single joint. Length about $10 \mathrm{~mm}$.

Male.-The male has a general resemblance to the male of a Lepeophtheinus. The antennules are provided with adhesive disks as in the female, but differ in being armed with terminal claws; the second maxillipeds are also furnished with distinct though small claw-like hooks. All the four pairs of thoracic legs are biramose with biarticulate rami; the rami also differ from those of the female in being provided with moderately long and densely plumose setæ. The genital segment is subquadriform and equal to scarcely one-fourth of the total length, and the abdomen is composed of two segments. Length about $6 \mathrm{~mm}$.

Habitat.-Parasitic on various dog-fishes and sharks: Galeus canis (Squalus galeus Linn.); Carcharias glaucus; 
Scyllium catulus; and Squalus mustelus. Falmouth 1849 (W. P. Coclss-see Baird). Torcross, Devon (Dr. Leach). Plymouth (A. M. Norman and Bassett-Smith). Firth of Clyde, Aberdeen, Moray Firth $\left(T \cdot{ }^{*} S \operatorname{Scot} t\right)$. Shetland (C.B. Wilson). Irish Sea (A. Scott).

This appears to be the only British species of Pandarus recorded hitherto. Pandarus boscii Leach is considered to be only a pale-coloured variety ; an apparently similar variety -pale-coloured-is recorded in the 26th 'Annual Report of the Fishery Board for Scotland,' Part III, p. 74, pl. iii (1909). It was obtained along with specimens of the typical form on a number of Squalus acanthias captured on the West Coast of Scotland in March 1908. Pandarus fissicornis M. Edw. is regarded by Kröyer as synonymous with the present species, and Canon A. M. Norman considers that the species described by Gerstaecker under the name of Nogagus angustulus is the male of this Pandarus. The female of the typical form is ornamented on the back with dark-brownish or almost black coloured patches. The carapace is usually coloured, and so are the second and third pairs of thoracic plates.

\section{Genus 16. CECROPS Leach, 1816.}

Female.-Carapace oval, robust, distinctly notched in front and deeply excavated posteriorly. Frontal plates coalescent with the carapace. Second thoracic segment with tolerably large rounded lateral lobes, and the last one with a pair of short dorsal plates. Genital segment small but provided with considerably expanded dorsal plates, larger than the carapace, and reaching backward so as to conceal the short caudal rami. Abdomen small, somewhat flattened.

Antennules small, two-jointed. Antennæ moderately stout, each terminating in a strong hook. Mandibles and other mouth-organs of the usual caligoid type. All four pairs of thoracic legs biramose. Both rami of the first three pairs composed of two joints, and those of the fourth pair of one joint.

Male.-The male, which is smaller than the female, is similar to it, except that the genital segment wants

roL. I. 
the large dorsal plates which the female possesses. The frontal sinus is also not so pronounced.

\section{Cecrops latreillii Leach.}

(Plate XXI, figs. 3, 4; Plate XXVII, figs. 9, 10 ;

Plate XXVIII, figs. 1-7.)

1816. Cecrops latreillii Leach. (74) p. 20, and five figures.

1850. Cecrops latreillii Baird. (4) p. 293 , pl. xxxiv, fig. 1.

1857. Cecrops latreillii Hœven. (6la) Mém. d'Entomol. de la Soc. Entom. des Pays-bas, vol. i, p. 67, pls. iii \& iv.

1892. Cecrops latreillii A. Scott. Trans. Nat. Hist. Soc. Glasgow, vol. iii, pt. 3 , p. 266.

1900. Cecrops latreillii T. Scott. (112) p. 157.

1907. Cecrops latreillii C. B. Wilson. (148) p. 468, pls. xxxviii \& xxxix.

1909. Cecrops latreillii E. V. Elwes. (45) p. 20.

1910. Cecrops latreillii T. R. R. Stebbing. (125) p. 558.

Female.-Carapace oval, stout, length and width nearly equal, deeply emarginate in front, and with the posterior margin deeply excavated. Second and third thoracic segments apparently coalescent and forming. one segment which bears a dorsal plate with broadlyrounded lateral lobes. The last thoracic segment with a tolerably large dorsal plate, the front margin of which is nearly straight, but posteriorly of a semicircular outline and reaching to near the middle of the genital segment; a narrow and moderately deep cleft or sinus dividing the plate in the median line at its posterior margin. The dorsal plates of the genital segment nearly twice as long as the carapace and extending backward so as to conceal the abdomen and caudal rami; their inner margins contiguous and apparently coalescent, forming a single plate which is wider than the carapace and terminates posteriorly in two equal and broadly-rounded lobes; the genital segment covered by these coalescent plates narrow and flattened, and the abdomen and caudal rami small.

Antennules two-jointed, end joint small. Antennæ armed with strong, hooked, terminal claws. Second maxillipeds stout, terminal claws strong and hooklike. All the four pairs of thoracic legs biramose and 
both rami two-jointed, except in the fourth pair, the rami of which are both uniarticulate. The outer. ramus in the first three pairs stouter than the inner, and the first joint larger than the end one, and carrying on its outer distal angle a short but stout spine. The outer ramus in the fourth pair small, but the inner considerably expanded and so also is the basal joint of this pair. Caudal rami short and furnished with a few apical setæ. Length about $25 \mathrm{~mm}$.

Male.-The male differs from the female in being smaller, and it also wants the large posterior dorsal plates of the genital segment. Some of the thoracic legs are also slightly modified. Length about $16 \mathrm{~mm}$.

Habitat.-Parasitic on the gills of the short sun-fish, Orthagoriscus mola. Recorded from many parts of our coasts. South of Ireland, Dublin, Coast of Antrim, \&c. (G. J. Allman-Aug. 1848, R. Ball, W. Thompson,-see Baird, p. 293). Polperro (A. M. Norman). Plymouth (Bassett-Smith). Falmouth (Cocks). Solway, Jan. 1857 (J. Stewart). Firth of Forth (A. Scott). Lerwick, Shetland; Mallaig, W. coast of Scotland (T'. Scott). On a short sun-fish captured off Berry Head (Majoi E. V. Elwes).

In the female the egg-strings are very long, but instead of projecting externally they are twisted upon each other in numerous loops and lie concealed in the hollow space between the abdomen and the large buckler-shaped last segment of the thorax. The specimens we have seen have all been obtained from the gills of the short sun-fish, where large numbers may sometimes be found crowded together. The general colour of the parasites is yellowish, but the colour of the strong terminal hooks of the maxillipeds is dark brown, nearly black.

Cecrops latreillii appears to be one of the most widely dispersed species of the Caligidæ; in addition to the European records of this parasite, it has also been reported from both the Atlantic and Pacific coasts of North America, and G. M. Thomson states that several specimens were obtained from the mouth of a sun-fish (Orthagoriscus mola) which was caught in Otago Harbour (Otago Museum).*

* 'Trans. N. Z. Institute,' vol. xxii (18s9), p. 362. 
Genus 17. ORTHAGORISCICOLA Poche, 1902.

Syn. Læmargus Kröyer. (Name preoccupied for' a genus of fishes.)

Female.-Carapace, outline trapezoidal, considerably narrower in front, posterior corners rounded, length equal to about three-fourths of the width at the widest part. The first and second thoracic segments very short and fully half as wide as the carapace. Third segment provided with an expanded dorsal plate, which overlaps a considerable portion of the genital segment and is divided posteriorly by a median cleft into two broadly-rounded lobes. Genital segment enlarged, dorsal plates greatly expanded, contiguous, slightly overlapping each other in the median line, and, viewed from the dorsal aspect, entirely concealing the abdomen and caudal rami.

Antennules tolerably elongated and composed of three joints. Antennæ, mandibles, and maxillipeds somewhat similar to those of Philorthragoriscus. All the thoracic legs biramous; the first and second pairs both somewhat similar to the normal type observed in this group of parasites, but in the third and fourth pairs the rami consist of broad one-jointed lamine almost devoid of spines or setæ.

Male.-The male resembles the female but is rather smaller. The structure of the appendages does not greatly differ except that the antenna and second maxillipeds are armed with stronger terminal claws ; the rami of the third pair of thoracic legs are also biarticulate.

Kröyer established this genus in 1837 under the name of Læmargus, but it happened that only a short time before the same name had been given to a genus of fishes by Henle (1837).

\section{Orthagoriscicola muricata (Kröyer).}

(Plate XXI, fig. 5; Plate XXVIII, figs. 8-18.)

1537. Læmargus muricatus Kröyer. (70) p. 487, pl. v, figs. A-E.

1850. Lrmargus muricatus Baird. (4) p. 295 , pl. xxxiv, figs. 3 \& 4.

1857. Læmargus muvicatus Hœven. (6la) Op. cit. p. 11, pl. iv, figs. $1-10,12,14,15$. 
1861. Lrmargus muricatus P. J. van Beneden. (15) p. 129, pl. xix, figs. 1-4.

1892. Lrmargus muricatus A. Scott. Trans. Nat. Hist. Soc. Glasgow, vol. iii, pt. 3, p. 266.

1900. Læmargus nuricatus T. Scott. (112) p. 158, pl. vi, figs. 39-42.

1902. Orthagoriscicola muricata Poche. (97) p. 14.

1907. Orthagoriscicola muricata C. B. Wilson. (148) p. 4i3, pls. xl \& xli.

1909. Orthagoriscicola muricata E. V. Elwes. (45) p. 20.

1910. Orthagoriscicola muricata T. R. R. Stebbing. (125) p. 559.

Female.-Carapace trapezoidal in outline, much wider behind than in front, postero-lateral corners broadly rounded, lateral margins minutely serrated, posterior margin slightly incurved, a number of minute spines scattered over the dorsal surface of the carapace, and the frontal plates apparently fused with it. First and second thoracic segments short and about half as wide as the carapace, attenuated at the sides and without accessory dorsal plates. The next segment provided with a broad dorsal plate which overlaps a considerable portion of the genital segment and is divided by a median cleft into two broadly-rounded lobes the margins of which are minutely serrated. The genital segment furnished with two large broadlyexpanded plates the inner margins of which somewhat overlap each other; the plates suborbicular in ontline and together fully one and a half times the width of the carapace, also entirely concealing the abdomen and caudal rami; their posterior margins broadly rounded and conspicuously serrated.

Antennules of moderate length and composed of three joints, the first as long as the other two combined. Antennæ short, armed with stout and stronglyhooked terminal claws. Mandibles long, stylet-shaped, and minutely serrate at the distal end. First maxillipeds small, provided with short but moderately broad terminal claws serrated on the margins. Second maxillipeds strong; end joint with one or two marginal processes on its inner aspect and provided with a strong curved terminal claw considerably shorter than the joint to which it is articulated. The thoracic legs all biramose, the rami of the first and second pairs 
two-jointed, but those of the third and fourth pairs uniarticulate, tolerably large, and lamelliform. Length about $20 \mathrm{~mm}$.

Male.-The male does not differ greatly from the female, but it is only about half or three-quarters the size, and the dorsal plates of the thorax and genital segment are proportionately smaller; the dorsal plates of the genital segment have also their inner margins apparently coalescent except at the posterior end, where they are separated by a moderately deep sinus; they scarcely extend so far back as in the female, so that the caudal rami are exposed.

The antennæ and the second maxillipeds are also stronger and form more powerful grasping organs than those of the female; the rami of the third pair of thoracic legs. are not foliaceous, but, like the first and second, are biarticulate; they differ however in the inner ramus being small and somewhat rudimentary. The fourth pair are similar to the fourth pair in the female. Length from 10 to $15 \mathrm{~mm}$.

In both sexes the colour is dull yellow.

Habitat.-Parasitic on the short sun-fish, Orthagoriscus mola. "Specimens taken off Plymouth were given to A. M. Norman a great many years ago by the late Mr. C. Spence Bate."* Moray Firth (T. Edward). Firth of Forth, October 1890 (A. Scott). Dr. Baird records this parasite on the authority of W. Yarrell, but does not mention the locality. On a short sun-fish captured off Berry Head, 1898 (Major E. V. Ellwes, Babbacombe).

Distribution. - European Seas. South Africa (T. R. R. Stebbing). New Zealand (G. M. Thomson). The Atlantic and Pacific coasts of North America (C. B. Wilson).

* 'The Crustacea of Devon and Cornwall,' 1906, p. 211. 


\section{Genus 18. PHILORTHRAGORISCUS Horst, 1897.}

Syn. Dinematura Kröyer, in part.

Female-Carapace suborbicular, width somewhat exceeding the length. First thoracic segment fused with the head; second and third united together, forming one segment, provided with small lateral expansions. Fourth segment furnished with a large dorsal plate, overlapping fully the half of the genital segment, about as wide as the carapace and divided into two suborbicular lobes by a median fissure which extends nearly to the base of the plate. The genital segment also furnished with a bilobed dorsal plate, nearly as wide as that of the fourth segment, and, viewed from above, almost concealing the comparatively small abdomen. Caudal rami short and tolerably broad.

Antennules two-jointed and tolerably elongated. Antennæ stout and armed with large hook-like terminal claws. Mandibles long and slender. First maxillipeds composed of two joints and provided with three terminal spines, two of them being of moderate length and claw-like. Second maxillipeds stout and bearing strong terminal claws. First four pairs of swimminglegs biramose; both rami of the first three pairs biarticulate. Caudal rami short.

Male. - The carapace of the male is much larger than the rest of the body; width greater than the length, dorsal surface grooved as in Pandurus. Second and third thoracic segments coalescent, and furnished with a pair of small lateral plates. Fourth segment with very small dorsal plates, which are coalescent along the middle line, while the posterior margin with its intermediate sinus is similar to that of the genital segment in the female of Perissopus. Abdomen as in the female but more exposed behind the genital segment. Candal rami rather smaller than in the female.

Antennules proportionately longer; the antenna also enlarged, their terminal claws projecting well in 
front of the carapace. Other appendages somewhat similar to those of the female.

We are indebted to Major E. V. Elwes, Babbacombe, for the privilege of examining and describing the male, he having kindly sent it to us for that purpose along with specimens of the female.

\section{Philorthragoriscus serratus (Kröyer).}

(Plate XXIV, figs. 3, 4; Plate XXVII, figs. 11-24.)

1863. Dinematura serrata Kröyer. (71) p. 176, pl. viii, fig. $4 a-i$.

1897. Philorthragoriscus serratus Horst. (63a) Notes Leyden Museum, vol. 19 N. $\frac{1}{2}$, Note xiv, p. 137, pl. vii.

1901. Dinematura serrata T. Scott. (113) p. 125.

1906. Philorthragoriscus serratus A. Brian. (21) p. 53.

1907. Philorthragoriscus serratus C. B. Wilson. (147) p. 479, pls. xlii \& xliii.

1909. Philorthragoriscus serratus E. V. Elwes. (45) p. 20.

Female.-Carapace, which is generally described in the generic definition, with the lateral margin denticulate. The antero-lateral corners of the dorsal plates of the fourth segment produced outward into sharp teeth, and both lobes with their posterior margins also denticulate. The outer ramus in the first four pairs of thoracic legs considerably larger than the inner, the first joint being longer than the entire inner ramus, and having a small tooth on its outer distal angle; the end joint small and bearing a few small spines and setæ on its rounded apex; the joints of the inner ramus subequal, and the end joint somewhat expanded and furnished with three apical setæ. Basiopodites of the second and third pairs dilated, rami small. The basiopodite of the fourth pair also considerably enlarged, and both rami small, uniarticulate, and somewhat rudimentary, but the inner much smaller than the outer ramus. Egg-strings long and slender. Colour yellowish. Length about $7 \mathrm{~mm}$.

Male.-See under generic definition. Length $5 \mathrm{~mm}$.

Habitat.-Taken on a short sun-fish, Orthagoriscus mola (L.), at Banff in 1862 by the late Thomas Edward. On a short sun-fish captured off Berry Head, 1898 (E. V. Elwes). 
Distribution.-European seas. Atlantic coast of North America (C. B. Wilson).

The species will be found recorded under the Rev. A. M. Norman's MS. name Monima fimbriata in the appendix to Smiles' 'Life of 'l'homas Edward' (p. 437, 1876), as one of the many creatures that keen-sighted naturalist added to the fauna of Scotland. 'The same species was also found on a short sun-fish captured by Mr. C. Beadle, off Berry Head, in August 1908, and presented by him to the Torquay Natural History Society. On this sun-fish Major E. V. Elwes obtained, among other interesting parasites, four female and one male Philorthragoriscus serratus which he very kindly permitted us to examine.

\section{Family iII. DicheLeST'IID \&.}

Body generally elongated, head moderately small. Free thoracic segments usually simple, but sometimes provided with dorsal plates. Abdomen usually small or rudimentary.

Antennules slender, moderately elongated, and composed of several joints, rarely short with two or three joints. Antennæ armed with terminal claws and generally projecting more or less beyond the edge of the cephalothorax. Mouth parts somewhat similar to those of the Caligidæ. Thoracic legs usually four pairs, frequently short, stump-like or suppressed, or with the posterior limbs transformed into lamelliform plates. Eye single, median, or absent. Genital organs as in the Caligidæ. Sexual differences not very marked, but the male usually smaller than the female, and both for the most part capable of a certain amount of locomotion.

\section{Genus 19. DICHELESTIUM Hermann, 1804.}

Head obtuse, body elongated, consisting of four distinctly-articulated segments without dorsal plates. Genital segment tolerably elongated. Abdomen small. Caudal rami not very prominent.

Antennules slender and composed of eight joints. 
Antennæ large, as long as the antennules, and cheleform or uncinate at the end, usually projecting forward beyond the front of the head. The first and second pairs of thoracic legs small and biramose, but the fourth pair each composed of a single one-jointed lamelliform plate.

The male is somewhat similar to the female, but smaller.

\section{Dichelestium oblongum (Abildgaard).}

\section{(Plate XXXI, figs. 7-18; Plate XLV, figs. 4, 5.)}

1794. Caligus oblongus Abildgaard. (1) vol. iii, p. 52, pl. v, figs. 4-11. 1804. Dichelestium sturionis Hermann. (61) p. 125, pl. v, figs. 7 \& 8 . 1838. Dichelestium sturionis Kröyer. (70) vol. i, p. 299, pl. ii, fig. 5, $5 a$. 1836. Dichelestium sturionis Rathke. (99a) Act. Akad. Leopold Carol, vol. xix, p. 127, pl. xvii, figs. 1-17.

1840. Dichelestium sturionis M. Edw. (43) p. 485, pl. xxxix, fig. 4.

190う. Dichelestium sturionis T. Scott. (116) p. 111, pl.v, figs. 17-24; pl. vi, figs. 1-6.

1906. Dichelestium oblongum Norman \& T. Scott. (SS) p. 215.

Female.-Body elongated, narrow ; carapace nearly as broad as long and somewhat rhomboid in outline, widest behind the middle, and with the sides bluntly angulated; it is also obscurely lobed in front and narrowed and truncated behind. Thoracic segments four, the first and second short and subequal, but the first produced laterally into short rounded lobes directed backwards, the second having the sides also lobate but produced slightly outwards. The third segment, which is rather longer than the preceding one, widest behind, and with a slight constriction in the middle. The fourth segment similarly constricted, and somewhat longer than the third. The genital segment about one and a half times the length of the preceding segment and tapering slightly towards the posterior end. Abdomen short. Caudal rami small; egg-strings long and narrow.

Antennules moderately short and slender and composed of eight subequal joints. Antennæ stout, and extending prominently in front of the carapace; indistinctly three- or four-jointed, the end joint slightly 
reflexed and furnished with a small apical claw which can be folded inwards so as to impinge against a rounded knob and thus form a tolerably powerful grasping-organ. Mandibles somewhat like those of Caligus except that the basal part is rather stouter. Maxillæ small, biramose, primary branch stout, tapering towards the distal end, and bearing two slender apical setæ; secondary branch very small. The first maxillipeds with the first and second joints of nearly equal length, but the first is more robust; end joint very small and bearing a few short spines and setæ. Second maxillipeds short, robust, and furnished with stout terminal claws. Thoracic legs short and stout, and the first and second pairs biramose. Both rami of the first pair indistinctly two-jointed, the proximal joint of the outer ramus having a small spine on its outer distal angle while the end joint has five spines: all moderately stont, on its rounded apex; the inner ramus, which is shorter than the outer, carrying two terminal spines. The second pair similar to the first but the outer branch rather stouter and the spines shorter; the inner branch also proportionally rather shorter. The fourth pair one-branched and each branch consisting of a single uniarticulate, lamelliform plate, rather longer than broad, with a few minute prickles round the distal end. Length 17 to $18 \mathrm{~mm}$., but varying somewhat.

Male. - The male bears a close resemblance to the female, but is considerably smaller, and the genital segment is proportionally shorter. In the second pair of thoracic legs the inner branch is very short and broad, and bears on its onter aspect a small flattened plate. The fourth pair are also proportionally shorter and broader. Length about $13 \mathrm{~mm}$.

Habitat.-Parasitic on the gills of the sturgeon, Acipenses sturio. On a sturgeon captured at Polperro, Cornwall, in 1867 (A. M. Norman). On a sturgeon captured abont sixteen miles S.E. by E. of Aberdeen in December 1904 (Th: Alex Bouman). On a sturgeon 
captured near Barrow-in-Furness, Lancashire ( $A$. Scott).

The structure of the mouth-organs of Dichelestium, and especially of the mandibles, shows a somewhat close relationship with the Caligidæ. 'The parasite seems to be peculiar' to the sturgeon, and to have a distribution coextensive with that of the fish.

\section{Genus 20. ANTHOSOMA Leach, 1816.}

Cephalothorax of considerable size, in the form of a narrow ovoid buckler having attached to it near the mouth a pair of large foot-jaws armed with strong. hooks. Genital segment furnished with elytraform appendages. Thoracic feet, three pairs, all foliaceous.

The two sexes are somewhat similar except that, in the female, the genital segment and abdomen are almost entirely concealed by the elytraform appendages, but are more or less exposed in the male.

\section{Anthosoma crassum (Abildgaard).}

\section{(Plate XXIII, figs. 5, 6.)}

1794. Caligus crassus Abildg. (1) vol. iii, p. 54, pl. v, figs. 1-3.

1816. Caligus imbricatus Risso. Hist. nat. Crust. des Environs de Nice, p. 162, pl. iii, fig. 13.

1816. Anthosoma smithii Leach. (74) p. 406, pl. xx, fig. 1 .

1838. Anthosoma smithii Kröyer. (70) vol. i, p. 295, pl. ii, figs. 2 \& 2 a. 1\&50. Anthosoma smithii Baird. (4) p. 296, pl. xxxiii. fig. 9.

1861. Anthosoma crassum Stp. \& Ltk. (ठర). (127) p. 397, pl. xxii, fig. 24. 1905. Anthosoma crassum T. Scott. (116) p. 112, pl. v, figs. 15 \& 16.

1906. Anthosoma crassum Norman \& T. Scott. (88) p. 214.

Female.-Tolerably elongated, and, when seen from above, ovate in general outline but narrowed in front. The head and a considerable portion of the thorax covered by a brownish-coloured horny shield which gradually expands towards the posterior end, and the junction of the thorax with the head marked by an obscure constriction. The remaining portion of the thorax, and also the abdomen and caudal rami, covered 
entirely by two large foliaceous elytraform circular plates, the inner margins of which partly overlap each other on the dorsal aspect, these plates being ornamented with numerous minute scattered punctures or depressions.

Antennules moderately short, and composed of six sparingly-setiferous joints; the antennæ stout, three-jointed, longer than the antennules, and armed with strong terminal hook-like claws. First maxillipeds slender and feebly armed, apparently consisting of three joints, the end one being small and of a peculiar shape; second maxillipeds short, very stout, and furnished with strong terminal claws. Thoracic legs in the form of thin and broadly-foliaceous plates each with a distinct notch on the inner margin, concealing the genital segment as well as part of the abdomen. Caudal rami narrow and moderately elongated. Length about $15 \mathrm{~mm}$. Egg-strings long and slender, reaching in length from 40 to about $50 \mathrm{~mm}$.

The shield is of a chitinous texture, the colour on the sides is yellowish but merging into blackish-brown along the middle and towards the front; the elytraform plates and thoracic feet, which also appear to be slightly chitinous, are whitish with a slight tinge of yellow.

Male.-The male has a close resemblance to the female, except that the large dorsal plates which cover the posterior portion of the female are wanting.

This interesting species was found on what was supposed to be a porbeagle shark (Lamna cornubica) captured off the coast of Scotland in October 1904, by one of the trawling steamers which make only short runs from Aberdeen and which are locally known as " short trippers." Two specimens of the Anthosoma were obtained-the one described here and a smaller one, probably a male. We are indebted to the kindness of Mr. Irvine, Aberdeen, for the specimen here described. Dr. Baird states (op. cit., p. 299) that a specimen was " discovered sticking to a shark (the Lamna cornubica) thrown ashore at Exmouth, Devonshire, by T. Smith, Esq., of the Temple, who sent it to Dr. Leach, British Museum.' 
Anthosoma crassum has apparently a wide distribution in both the north and south hemispheres. Mr. G. M. Thomson of New Zealand, after describing the species, states that "numerous specimens were taken from the upper jaw of a porbeagle shark, Lamnu cornubica (Otago Museum). Also a number from the same kind of shark taken at Napier by A. Hamilton"; and he adds that "according to Gould this species has been taken on the mackerel-shark, Lamna punctata, on the coast of Massachusetts, U.S.A."**

\section{Genus 21. IERNANTHROPUS Blainville, 182:3.}

Body broadly ovate, depressed. Cephalon oblong or pyriform, with the sides incurved. Neck distinct; the posterior part in the female covered by a large dorsal shield sometimes divided into two portions by a transverse constriction, and prolonged backwards so as to conceal more or less completely both the genital segment and the abdomen; in the male the dorsal shield not being so large as to conceal the abdomen.

Antennules slender, composed of five or moreusually seven-articulations, and sometimes furnished with supplementary appendages. Antenna robust and armed with strong terminal hooks. Other mouthorgans somerwhat similar to those of the Caligidie. Thoracic legs biramose; the first and second pairs very small and rudimentary; the third and fourth tolerably large; rami lamelliform, those of the last pair usually, and sometimes those also of the others, forming elongated appendages with their distal ends more or less attenuated.

\section{Lernanthropus kröyeri P. J. van Beneden.}

\section{(Plate XXIX, figs. 2-5; Plate XXX, figs. 9-17.)}

1851. Levnanthropus kröyeri P. J. van Ben. (11) p. 102, pl. iii, figs. 7-9. 1858. Lernanthropus kröyeri Claus. (30) p. 18, pl. ii, figs. 15-19.

1864. Lernanthropus kröyer $i$ Nordmann. (90) p. 508, pl. vii, figs. 5-8. 1879. Lernanthropus kröyeri Heider. (56) vol. ii, p. 90, pl. v, figs. $72-73$.

1896. Lernanthropus kröyeri Bassett-Smith. (7) p. 159.

1904. Lernanthropus liröyeri A. Scott. (109) p. 43.

* 'Trans. N. Z. Institute,' vol xxii (1889), p. 366. 
Female.-The body, which is oblong in shape, somewhat flattened and rather wider towards the posterior end, and divided into three unequal, but moderately distinct, portions; the head, which is the shortest, equal to about one-fourth of the entire length of the animal, exclusive of the posterior appendages, widest behind and tapering slightly on each side forwards to the flatly-rounded forehead; the next two segments larger and subquadriform, but the last segment about a third longer than the middle one. The genital segment and abdomen, which are small, entirely concealed in dorsal view; caudal rami moderately stout and elongated.

Antennules moderately short and composed of seven joints, basal joint robust, the others small; a slender two- or three-jointed appendage springing from near, but a little behind, the base of each of the antennules, and reaching to fully beyond their apex. Antennæ short, robust, and furnished with short but strong terminal claws; mandibles and maxillæ slender; maxillipeds short, stout, and strongly uncinate. Thoracic legs biramose; first and second pairs very small and rudimentary, the inner ramus uniarticulate and rather more robust than the outer, which consists of one or two small joints.

Other appendages occur on the ventral aspect which are referred to by Steenstrup and Lütken and others as the third and fourth pairs of legs. The third pair consist each of a one-jointed linguliform appendage which reaches to near the base of the next pair; the fourth pair have each two branches; they form elongated one-jointed appendages which reach backwards considerably beyond the posterior end of the body; they are nearly of equal length, and taper towards the blunt-pointed extremity.

Colour dark red. Length about $21 \mathrm{~mm}$.

Male.-The male, which is only about half the size of the female, has a general resemblance to it, but the head is proportionally larger, the dorsal shield is 
smaller, and the urosome and caudal rami are not covered. The third and fourth pairs of ventral appendages are also more prominent.

Habitat.-Parasitic on the gills of the bass or sea-perch, Labrax lupus. Plymouth (Bassett-Smith). Barrow Channel, Lancashire (A. Scott).

\section{Genus 22. HATSCHEKIA Poche, 1902.}

Syn. Clavella Kröyer (1838) and others but not Oken, 1815.

Body elongated and narrow. Cephalon distinct, small, usually rounded. Thorax short, obscurely biarticulated, without dorsal plates. Genital segment much elongated, narrow, and subcylindrical, five or six times the length of the cephalothorax. Abdomen and caudal rami very short or obsolete.

Antennules small and composed usually of not more than six articulations. Antennæ short and stout, with strong terminal hooks, sometimes and perhaps generally with a slender spiniform or other appendage at the base of each antenna. Mandibles and maxillæ small. First maxillipeds apparently obsolete. Second maxillipeds slender and uncinate. Thoracic legs two pairs, very short, and two-branched.

Professor van Beneden remarks that this genus is perfectly characterized and easy to distinguish by the length of the body; by the three pairs of appendages that follow the antennæ; and by the two pairs of short biramose feet.

\section{Hatschekia hippoglossi (Kröyer).}

(Plate XXXIII, figs. 3, 4; Plate XXXIV, figs. 8-11.)

1838. Clavella hippoglossi Kröyer. (70) p. 196, pl. ii, fig. 3 .

1829-1843. Clavella hippoglossi Guérin. (55) Icon. du Règne Anim., Crustaces, pl. x, fig. 7 .

1840. Clavella hippoglossi M. Edwards. (43) vol. iii, p. 494.

1851. Clavella hippoglossi P. J. van Beneden. (11) p. 100, pl. iii, figs. 5 \& 6 .

1900. Clavella hippoglossi T. Scott. (112) p. 159, pl. vii, figs. 1-6.

Female.-Body slender, elongated, and subcylindrical. Cephalon small, of an oval form, width greater 
than the length, sides rounded. Between the cephalon and the genital segment is a short neck, narrow and indistinctly segmented, and provided with rounded lobes on each side. Genital segment considerably elongated and rather narrow, its width scarcely equal to one-fourth of the length, and with the posterolateral corners produced into rounded lobes about equal in size to the small abdomen that is intermediate between them and which is also rounded; the posterior end has thus a trilobed appearance. Caudal rami extremely small.

Antennules short, rather stout, and composed of five small joints which are sparingly setiferous. Antennæ tolerably large and armed with strong terminal hooks and with a small appendage at the base. Mandibles small, elongated, tapering distally, and provided with a few small teeth at the distal end of the inner margin. Maxillæ very small but comparatively stout, and furnished with two or three tooth-like processes.

Maxillipeds elongated and slender. Thoracic legs two pairs, short and biramose, both rami appearing to be composed of two somewhat indistinct joints. Length about $9 \mathrm{~mm}$.; length of head and neck combined $1.5 \mathrm{~mm}$. Egg-strings long and slender. Colour resembling that of the gills to which the parasite was adhering.

Male. - The male is much smaller than the female but has a general resemblance to it. The cephalon is proportionally rather larger and the thoracic ring is distinctly segmented. The genital segment is also proportionally much shorter than in the female, being only about twice as long as broad.

Antennules short, composed of five joints. Antennæ provided with large and strong hooks, projecting well in front of the cephalon. Caudal rami narrow and more prominent than in the female. Length $1.5 \mathrm{~mm}$.

Habitat.-Parasitic on the gills of halibut, Hippoglossus vulgaris; not uncommon. The reddish coloured, thread-like egg-strings may sometimes be 
observed projecting beyond the edges of the gillfilaments. Frequently observed on halibut brought to the Fish-Market at Aberdeen.

'The males are apparently very rare. Though many specimens of halibut have been examined, only one male specimen of this species has been met with.

\section{Hatschekia mulli (P. J. van Beneden). \\ (Plate XXXII, figs. 1-11.)}

1851. Clavella mulli P. J. van Beneden. (11) p. 99, pl. iii, figs. 3 \& 4. 1896. Clavella mulli Bassett-Smith. (7) p. 159.

1906. Clavella mulli Norman \& T. Scott. (88) p. 215.

Female.-Body narrow, elongated, and sub-cylindrical; head small, subglobose, but the width rather greater than the length; front somewhat lobate and without any horn-like processes. Neck very short, the thorax, which is indistinctly segmented, merging almost imperceptibly into the genital segment; on the dorsal aspect of the thorax, and on each side of the median line, a small rounded protuberance, seen best in lateral view (Pl. XXXII, fig. 2). Genital segment elongated and narrow, slightly expanded in the middle and tapering gradually towards both ends, greatest width equal to about one-fourth of the entire length of the animal; posterior end trilobed, lateral lobes small and distinct, and produced slightly outwards, the middle one broad and not very prominent.

The cephalothoracic appendages comprise the antennules, which are moderately small and composed of three spinulose joints, the last one with also a few apical spines; the antennæ, composed each of a single large and moderately long basal part, and furnished with a stout terminal hook-like claw; there is also at the base of each antenna a small secondary appendage-probably a sense-organ (Pl. XXXIII, fig. 5). Mandibles small with the extremity slightly curved and hook-like. Maxillæ small, with both the internal and external rami considerably attenuated. Second maxillipeds moderately slender and somewhat similar 
to those of Hatschelia hippoglossi. Thoracic legs two pairs, each composed of a stout two-jointed basal part, which is furnished with two short two-jointed rami. Egg-strings long and slender. Length of adult female exclusive of egg-strings $3.4 \mathrm{~mm}$., and including eggstrings about $10 \mathrm{~mm}$.

No males have been observed.

Habitat.-Parasitic on the gills of red mullet, Mullus barbatus. Recorded from Plymouth by Dr. BassettSmith. Observed also on the gills of four specimens of red mullet sent to us from Looe, Cornwall, by Mr. N. M. Richards of that town, and on one from Plymouth sent by Dr. E. J. Allen, Director of the Plymouth Laboratory. It was also on Mullus barbatus that Professor van Beneden obtained his specimens of Hatschelia mulli.

A feature which appears to be peculiar to this species, and which was also noticed by van Beneden, is the secondary process at the base of each antenna: this process differs from that of any of the other species known to us.

H. mulli is readily distinguished from other members of the genus recorded here by the dorsal humps on the thoracic region, and the small lateral lobes at the posterior end. A young female is represented in dorsal view at fig. 3 , and it also shows traces of the characters by which the species is distinguished.

\section{Hatschekia labracis (P. J. van Beneden).}

(Plate XXXIII, fig. 2 ; Plate XXXIV, figs. 6, 7.)

1870. Clavella labracis P. J. van Beneden. (16) pp. 45 \& 46, pl. i, fig. 4. 1901. Clavella labracis T. Scott. (113) p. 127.

1902. Clavella labracis T. Scott. (114) p. 292, pl. xiii, figs. 10-12.

1904. Clavella labracis A. Scott. (109) p. 40.

Female.-Cephalothoracic segment, seen from the dorsal aspect, rhomboid or diamond-shaped, the lateral margins produced so as to form distinct angular projections; the width of the segment across the lateral angles rather greater than the length and equal to about a fifth of the entire length of the animal. Genital segment elongate-ovate, about three times as long as the cephalothorax, widest in the middle and with the 
lateral margins slightly convex. Abdomen and caudal rami very small.

Antennules short, moderately stout, and consisting of about five joints, the first large and equal to nearly all the other joints combined, and its lower distal angle produced downwards in the form of a strong hook; the three end joints subequal and shorter than the preceding one; several short, dagger-like spines springing from the upper margin of the various joints. Antennæ about as long as the antennules, two-jointed and armed with stout terminal claws; a small process in the form of a knob occurs at the base of each antenna. Mandibles and maxillæ small and simple in structure. Maxillipeds moderately slender, composed of two (or three) joints, and with the extremities uncinate. Thoracic legs two pairs, both biramose and somewhat similar in structure; the basiopodite consisting of two moderately stout joints and both rami also two-jointed, the inner ramus in both pairs being rather more robust than the outer one; the proximal joint of the outer ramus the largest and bearing a small spine on its outer distal angle, the joints of the inner ramus also unequal but the proximal one the smaller. Caudal rami short. Length about $1 \mathrm{~mm}$. Egg-strings fully as long as the animal, and with proportionately few but rather large ova. Colour similar to that of the gills of the host.

The male of this species has not yet been observed. Habitat.-Parasitic on the gills of the striped wrasse, Labrus mixtus Linn., and the ballan wrasse, Labrus. bergylta Ascan. (Labrus maculatus Bloch). Firth of Clyde (T.Scott). Irish Sea (A. Scott). Professor P. J. van Beneden states that Hatschelia labracis is abundant on both of the species of fish mentioned above.

This Hatschekia, though distinct enough, is very small and easily overlooked, but as the egg-strings are of a somewhat lighter colour than the gills of the fish, and tolerably elongated, they help to reveal the presence of the parasite. 


\section{Hatschekia cluthæ (T. Scott).}

\section{(Plate XXXIII, fig. 1; Plate XXXIV, figs. 1-5.)}

1902. Clavella cluthæ T. Scott. (114) p. 292, pl. xii, figs. 26-31.

Female.-With a general resemblance to the female of $H$. labracis (van Beneden) recorded above, but much larger, and the lateral margins of the cephalic segment evenly rounded instead of being angular as in that species. The genital segment, the form of which is also somewhat different from that of $H$. labracis, becoming gradually wider posteriorly, so that the widest part near the hinder end is about twice as wide as it is immediately posterior to the cephalon; the segment narrowing convexly and somewhat rapidly behind the widest part to the obscurely-angulated extremity. Abdomen and caudal rami very small.

Antennules apparently only four-jointed, moderately stout and furnished with a few minute spines, the basal joint about as long as the next three taken together, but the end joint very small. Antennæ fully as long as the antennules, and composed of two joints, each provided with a short but strong terminal hook-like claw. Maxillæ very small and simple in structure, consisting each of a minute papilliform basal joint, bearing three_small spines. Maxillipeds small, two-or three-jointed, and furnished with small terminal claws. Both pairs of thoracic legs biramose and somewhat similar in structure; the basiopodite tolerably stout and composed of two joints; the rami also twojointed, and armed with small terminal spines; the first joint of the outer ramus larger than the second and carrying a small spine at its outer distal angle, while on the other hand the end joint of the inner ramus is the larger one; the second basal joint also with a small spine on its inner distal angle.

Caudal rami very short; the egg-strings also tolerably short and slender. Colour somewhat similar to that of the gills of the fish. Length about $1.5 \mathrm{~mm}$. exclusive of the egg-strings. 
Habitat.-Parasitic on the gills of Jago's goldsinny, Ctenolabrus rupestris Linn., East Loch Tarbert (a branch of Loch Fyne) (T. Scott).

The male has not yet been observed.

The more obvious characters by which this species may be distinguished from $H$. labracis appear to be its larger size, the different form of the cephalon and genital segment, and the structure and armature of the antennules.

\section{Hatschekia cornigera T. Scott.}

\section{(Plate XXXV, figs. 1, 2 ; Plate XXXVI, figs. 1-5.)}

1909. Hatschekia cornigera T. Scott. (118) p. 74, pl. iii, figs. 1-7.

Female.-Body narrow and greatly elongated. Head proportionally very small and expanding laterally into broadly-rounded lobes, also produced backward, on the median dorsal aspect, into a blunt-pointed spurlike process; this segment being distinctly limited, by a constriction, from the thorax, which is narrow where it joins the head.

No distinct separation between the thorax and the genital segment, the one merging gradually into the other. Genital segment very long and narrow, and of about the same width thronghout-the width being only equal to about one-sixth of the length; the segment near its posterior end tapering to the narrow and obscurely bilobed extremity; abdomen very small and not clearly defined.

Antennules short, moderately stout, and composed of five articulations which are sparingly setiferous. Antennæ large and armed with strong and hook-like terminal claws. Mandibles and maxillæ somewhat similar to those of $H$. cluthæ. Maxillipeds tolerably elongated and slender, with a short spine arising from the inner aspect and near the proximal end of the second joint, the end joint terminating in a pair of not very strong and slightly-curved spines. Both pairs of thoracic legs biramose; the basiopodite considerably enlarged and composed of two articulations; the 
outer and inner rami also two-jointed and provided with a few apical spines. Caudal rami inconspicuous or obsolete. Length about $2.5 \mathrm{~mm}$. Egg-strings scarcely as long as the genital segment. Colour similar to that of the gills of the fish.

No males have been observed.

Habitat.-Parasitic on the gills of sea bream, Pagellus centrodontus De la Roche, captured in the North Sea and landed at the Fish-Market at Aberdeen during the early months of 1908 (T. Scott).

This species is very slender in proportion to its length, and in this respect it has a resemblance to Kroyeria; the head is also proportionally very small. When in situ on the gills of the fish, the parasite is not very conspicuous and may be easily overlooked. The horn-like process on the dorsal aspect of the cephalon, best seen in lateral view, is perhaps one of the more distinctive features of the species.

\section{Hatschekia pygmæa T. Scott.}

(Plate XXXV, figs. 3-7; Plate XXXVI, figs. 6-9.)

1907. Clavella labracis (?) P. J. van Beneden, A. Scott. (111) p. 95, pl. iv.

Female.-Antennules comparatively short, stout, and composed of five articulations, the first being robust and equal to about two-fifths of the entire length of the antennule, the next about half the size of the first, but the remaining three considerably smaller and subequal; the first and second joints furnished with a number of short spatulate hairs on their upper aspect; the first joint also with a short and stout spiniform seta on the lower distal angle, a minute seta springing from the lower margin of the third joint, while the end one has several similar setæ on its lower margin and apex and two small hooks on the upper distal angle as shown in the drawing (Pl. XXXV, fig. 4). Antennæ tolerably elongated and slender, and terminating in strongly-curved apical hooks. Mandibles and maxillæ judimentary, the former having apparently no serrated apex. Both pairs of thoracic legs biramose, small and more or less 
rudimentary; in the first pair both rami two-jointed, the outer ramus of the second pair also consisting of two joints but the inner one three-jointed. Caudal rami very small and inconspicuous. Length about $1 \mathrm{~mm}$. Colour similar to that of the gills of the fish. Egg-strings tolerably short and containing comparatively few but moderately large ova.

No males have been observed.

Habitat.-Found adhering to the gills of Crenilabrue melops (Linn.), the connor or goldsinny, captured in Luce Bay, Solway Firth $(A$. Scott).

This species, which was described in 1907, was at first doubtfully assigned to Clarella (or Hatschehia) labracis van Beneden; the examination, however, of additional specimens, obtained subsequently, showed that certain differences which had heen recognized in the first specimens were fairly constant, and were moreover sufficiently important to make it necessary to regard it as distinct from others that have been described.

In its general appearance this species has a resemblance to the Hatschekia labracis of van Beneden. It differs from that species in the head being rounded at the sides-not angular as in that species-in the armature of the antemnules, and in the terminal claws of the antennæe being much less strongly hooked, as well as in one or two other anatomical details. At the base of each antenna there is a small knob-like process similar to that on the antenna of Hatschekia lahracis. This fish is not the same as Jago's goldsinny, but belongs to a different species of the Wrasse family.

\section{Genus 23. KROYERIA P. J. van Beneden, 1853.}

Syn. Lonchidium Gerstaecker, 1854.

Cephalic segment moderately broad and plate-like, and furnished at the posterior end with movable styliform processes, projecting backwards. Three distinct, free thoracic segments, without lobes or dorsal plates. Genital segment long and narrowly cylindrical. Abdomen short, unsegmented in the female, and terminating in two lanceolate setose furca. Antennules composed of seven distinct joints. Antennæ very stout and cheliform. Mandibles and maxillæ rudimen- 
tary and resembling those of Eudactylina. Second pair of maxillipeds large and furnished with powerful claws. Thoracic legs, four pairs, well developed and biramose; each ramus three-jointed, and furnished on the inner margin with long plumose setæ.

The male has a general resemblance to the female but is considerably smaller. The thoracic and abdominal segments are also narrower than in the female, and the abdomen is distinctly three-jointed.

\section{Kroyeria lineata P. J. van Beneden. \\ (Plate LXX, figs. 1-13.)}

1853. Kroyeria lineata P. J. van Beneden. (13̂) Bull. Acad. Roy. Belg., vol. xx, p. 94.

1861. Kroyeria lineata idem. (15) Rec. sur les Crust. Belg., p. 149, pl. xxii.

1858. Kroyeria lineata Claus. (30) Beitrag Parasit. Crust., p. 24, pl. ii.

1880. Kroyeria lineata Valle. (141a) Boll. Soc. Adriat. Sc. Nat. vol. vi, p. 65 .

1885. Kroyeria lineata Carus. (29a) Podrom. Faunæ Mediterraneæ, p. 364 .

1899. Lonchidium lineatum Bassett-Smith. (8) Proc. Zool. Soc. Lond. 1899 , p. 473.

1906. Kroyeria lineata A. Brian. (21) Copepodi Parassiti dei Pesci d'Italia, p. 67, pl. v, fig. 3 .

Female.-Length, exclusive of the furcal setæ, $4.5 \mathrm{~mm}$. Cephalic segment moderately broad and flattened and having the antero-lateral margins concave, giving rise to a broadly-rounded forehead. Posterior margin furnished on each side with a strong movable spine, the apex of which is somewhat cheliform, and reaches to the end of the first free segment of the thorax. The eyes, two in number, situated in the front portion of the segment, a $V$-shaped band of chitin with a pointed end traversing the segment from front to rear (Pl. LXX, fig. 1). The three thoracic segments short and quadrangular in outline, the second being distinctly shorter than the other two. The third segment considerably longer than the first and nearly twice the length of the second, with its lateral margins slightly inflated posteriorly. All three segments provided with dorsal and lateral bars of chitin. Genital 
segment very long and narrowly cylindrical. Its distal end, in dorsal view, distinctly truncated, and in lateral view broadly rounded and somewhat gibbous (Pl. LXX, fig. 10). Abdomen short and narrow, joining the ventral surface of the distal end of the genital segment; uniarticulated, but in some specimens two slight constrictions appear which may correspond to the distinct segments seen in the male. Furcal joints moderately long and narrow, and about four times longer than broad. Egg-strings short and cylindrical, containing only a single row of eggs.

Antennules short and seven-jointed; moderately setiferous. Basal joint nearly as long as the combined lengths of the next five, and its distal end crossed by three indistinct lines as shown in the drawing (fig. 2). Distal end of the last joint provided with a short, but stont, sensory filament. Antennæ short and stout, and armed with powerful chelæ which are used for securing the parasite to its host, and are easily visible in the entire animal, even without dissection and by using an ordinary hand magnifier.

Mandibles stylet-shaped, with the distal end of the inner margin serrate as in Eudactylina. Maxilla bilobed, very small and somewhat rudimentary. The distal end of each lobe furnished with two setæ.

First maxillipeds small and cheliform, the claw-like end joint moderately broad and spoon-shaped; the distal end of the upper margin of the joint over which the claw folds slightly serrate and ciliated (fig. 6). Second maxillipeds large, and forming powerful prehensile organs, their terminal claw strongly curverl and nearly as long as the joint from which it springs.

The four pairs of thoracic legs all somewhat similar in structure. They are biramose, and the rami are three-jointed as shown by figs. 8 and 9 on Pl. LXX. Basal plate of the first pair produced at its distal angles into minute tubercles, but in that of the second, third, and fourth pairs the angles are produced into moderately long and stout spines which are quite pro- 
minent in the entire animal. No trace of a fifth pair of feet.

Male.-Length exclusive of the furcal setæ $2.7 \mathrm{~mm}$. The cephalic segment is similar to that of the female in every respect except in the shape and length of the movable spines at its distal end. The spines are evenly curved to the apex, and do not reach the end of the first thoracic segment. The first two segments of the thorax are nearly of equal size. The third segment is almost twice as long as the second, and its proximal lateral margins are slightly expanded. The genital segment is narrow and cylindrical, and distinctly longer than the combined lengths of the three thoracic segments. The abdomen is composed of three clearly-defined segments. The first segment is about half the length of the genital segment. The second and third are of nearly equal length, and are each about equal to two-thirds of the length of the genital segment. The furcal joints are almost similar to those of the female.

The various thoracic and other appendages are similar to those of the female, and therefore need not be described. A rudimentary fifth pair of feet represented by three ninute setæ can be detected by carefully examining the lateral margins of the genital segment.

Habitat.-In the hollows between the gill-rays of male specimens of Galeorhinus galeus or tope, captured in the Irish Sea in the vicinity of King William Bank, off the north end of the Isle of Man, April 1912. We have not yet met with this parasite on the gills of female specimens of the tope, although a considerable number of them have been examined. Much care is required to detect the parasite, as it is usually entirely hidden in the hollows between the gill-rays. The presence of the parasites is occasionally revealed by the egg-strings projecting beyond the ends of the gills. Several specimens of both sexes may sometimes be found on the gills of a single fish. 
The genus and species were both described by P. J. van Beneden in 1853. In the following year Gerstaecker described a closely allied parasite under the name Lonchidium aculeatum. Bassett-Smith in his work 'A Systematic Description of Parasitic Copepoda found on Fishes,' sets aside the generic name given by van Beneden and adopts Gerstaecker's Louchidium. Brian restores van Beneden's name in his work 'Copepodi Parassiti dei Pesci d'Italia,' and as we have been unable to find any satisfactory reason to support Bassett-Smith in changing the generic name, we have followed Brian in adhering to van Beneden's name Kroyeria. Spence Bate used the name Kroyera to distinguish a genus of Amphipoda in 1857, but Sars points ont in his 'Crustacea of Norway,' vol. i, that the name had already been appropriated in zoology. Brian apparently regards Gerstaecker's Lonchidium aculeatum to be nearly identical with Kroyeria lineata. We kept a number of specimens of both sexes alive in sea-water for a time, but were unable to detect them making any attempt to swim.

\section{Genus 24. CONGERICOLA P.J. van Beneden, 1854.}

Syn. Cycnus M. Edwards (1840), preoceupied by Hübner for a genus of Lepidoptera.

Head rounded, small; free thoracic segments two, without lobes or dorsal plates: genital segment elongated, narrow, and subcylindrical; abdomen short; caudal rami setiferous. Antennules composed of about six articulations; antennæ two-jointed and armed with terminal claws. Second maxillipeds slender. Thoracic legs four pairs, all biramose.

The only British species known to us is that described below.

\section{Congericola pallidaa P. J. van Beneden.}

$$
\text { (Plate XLI, fig. 1.) }
$$

1854. Congevicola pallida P. J. van Beneden. (14) vol. xxi,pt. 2, p. 583. 1861. Congericola pallida idem. (15) p. 148, pl. xxiii.

1896. Cycnus pallidus Bassett-Smith. (7) p. 159.

1900. Cycnus pallidus T. Scott. (112) p. 160.

1901. Cycnus pallidus A. Scott. (107) p. 350.

1906. Congericola pallida Norman \& T. Scott. (88) p. 215.

Female.-Cephalic segment small and suborbicular. 
Free thoracic segments two, very short, and without lobes or dorsal plates. Genital segment elongated, narrow, and subcylindrical. Abdomen short; caudal segments small and setiferous.

Antennules short and composed of about six joints, but one or two of the articulations are not very distinct; antennæ two-jointed, and provided with strong terminal hooked claws. Mouth-appendages somewhat similar to those in Hatschelia. Thoracic legs four pairs, biramose, and somewhat rudimentary. Colour pale reddish, scarcely so deep-coloured as the gills of the fish. Length, exclusive of egg-strings, about $4 \mathrm{~mm}$.; egg-strings slender and elongated, about twice as long as the animal.

This species, in its general appearance, has a somewhat close resemblance to Hat:chelia.

The male has not been observed.

Habitat. - Parasitic on the gills of conger eels, Conger vulgaris Cuv. (Conger niger, Risso). Plymouth (Bassett-Simith). Firth of Clyde and at Aberdeen ( $T$. $S \operatorname{sot} t)$. Lancashire coast (A. Scott).

'This parasite is not uncommon on the gills of large specimens of the conger, and sometimes occur's in considerable numbers. Thirty individuals have been taken from the gills of a single fish. The species has been recorded from the Adriatic (Dr. Graeffe) as well as from the coast of Belgium (P. J. van Beneden).

\section{Genus 25. EUDACTYLINA P.J. van Beneden, 1853.}

Female.-Cephalothorax composed of five segments ; cephalic segment obtuse, wider behind than in front; thoracic segments without dorsal plates or lateral processes. Abdomen, including the genital segment, considerably shorter than the cephalothorax and composed of three segments. Antennules short, stout, and usually five-jointed, basal joint usually provided with strong hooked spines; antennæ three-jointed and armed with stout terminal claws. Mandibles and 
maxillæ small, somewhat similar in structure to those of Hatschelia. First maxillipeds small, composed of three joints, and provided with a small terminal claw; second maxillipeds of moderate size, armed with terminal claws, strong and cheliform. First four pairs of thoracic legs short, biramose; rami of the first pair two- or three-jointed; those of the third and fourth pairs are usually both composed of three joints; but though in the second pair the inner ramus is somewhat similar in structure to that of the next pair, the outer one is more or less modified. Fifth pair consisting each of a small uniarticulate lamina; caudal rami short.

Male.-The male somewhat resembles the female, but differs in being smaller and in the antennules being armed with one or two moderately strong terminal hooks. 'The second maxillipeds are not cheliform but resemble in structure those in Hatschelia; the outer ramus of the second pair of thoracic legs is not modified, and there is also a difference in the form of the caudal rami. Moreover the abdomen, including the genital segment, is in the male nearly as long as the cephalothorax.

\section{Eudactylina acuta P. J. van Beneden.}

(Plate XXXVII, fig. 1; Plate XXXVIII, figs. 1-5.)

1853. Eudactylina acuta P. J. van Beneden. (13b) Bull. Acad. Roy. Belgique, vol. xx, pt.i, p. 235.

1861. Eudactylina acuta idem. (15) p. 150, pl. xxv.

1892. Eudactylina acuta Canu. (29) p. 52, pls. 2 \& 3.

1902. Eudactylina acuta T. Scott. (114) p. 293, pl. xii, figs. 20-25.

1904. Eudactylina acuta A. Scott. (109) p. 40.

Female.-Body slender and elongated; the cephalothorax consisting of five distinct segments, and the abdomen of three, including the genital segment. Cephalic segment about equal in length to the next two segments combined; the first of these two segments smaller than the second, the fourth and fifth subequal. Abdomen small and only a little more than 
one-fourth the length of the cephalothorax; caudal rami short and broadly ovate. Antennules short, stout, and composed of about five joints, and armed with several strong spines; a large strongly-curved spine springing from the upper distal angle of the second joint and reaching to near the end of the next joint; a stout but shorter spine on the lateral aspect of the same joint and also one or two spiniform setæ; a tolerably stout, elongated, and nearly straight spine springing from the upper distal end of the following joint, and immediately below, another, also moderately stout, but only half the length of the first; the penultimate joint also provided with a short spine, and a few spiniform setæ at its distal end ; the terminal joint very small. Antennæ small, but armed with stout terminal claw-like spines; also one or two stout spines on the inner aspect of the first and second joints. Mandibles slender, elongated; first maxillipeds small, three-jointed, and furnished with a minute terminal claw. Second maxillipeds of moderate size, each armed with a tolerably powerful, terminal chela which forms an effective grasping-organ, having a somewhat close resemblance to similar appendages in Pseudotanais - a genus belonging to Isopoda-Chelifera.

The first four pairs of thoracic legs all biramose ; in the first, third, and fourth pairs both the inner and outer ramus distinctly three-jointed; in the second pair the inner ramus composed of three subequal joints, but the outer somewhat abnormal in structure, the first joint comparatively large and fully as long as the entire inner ramus, while the distal extremity appears to consist of two minute coalescent joints; the basiopodite in all the four pairs composed of two unequal joints, the second being the smaller; the inner margin of the second basal joint in the first pair fringed with about five very short but stout spinules; the first and second joints of the outer ramus each with a small dagger-shaped spine on the outer distal angle, and the third joint with two similar spines and 
a moderately elongated seta at the apex; the inner ramus also provided with two spiniform apical setæ, and both rami furnished with marginal spinules as shown in the drawings; the armature of the rami of the third and fourth pairs somewhat similar to that described above, but in the second pair, while the armature of the inner ramus does not differ materially from that of the others, the outer ramus is devoid of either spines or setæ. Fifth pair small, uniarticulate, lamelliform, and broadly ovate, situated on the lateral aspect and near the distal end of the last thoracic segment, each furnished with about three apical setæ and their outer margins fringed with minute spines. Caudal rami short, nearly twice as long as broad, with two short stout spines at the apex, a small seta on the lower half of the outer margin, and a fringe of minute prickles on the lower inner margin. Length about $2.5 \mathrm{~mm}$. Egg-strings tolerably slender aud elongated. Colour similar to that of the gills, but the egg-strings are not so dark red.

No males have been observed.

Habitat.-Parasitic on the gills of the angel-fish, Rhina squatina (Linn.). Moray Firth and Firth of Clyde (T. Scott). Irish Sea (A. Scott). Not rare.

\section{Eudactylina acanthii A. Scott.}

\section{(Plate XXXVII, figs. 2, 3; Plate XXXVIII, figs. $6-12$.}

1901. Eudactylina acanthii A. Scott. (108) p. 14.

1902. Eudactylina acanthii T. Scott. (114) p. 296, pl. xiii, figs. 1-9.

1904. Eudactylina acanthii A. Scott. (109) p. 41.

Female.-Body moderately stout, cephalothorax equal to five times the length of the abdomen, including the genital segment; the first cephalothoracic segment about one and a half times the length of the next, the second and third subequal, the fourth rather larger than the third or the following segment. Abdomen very short, consisting of three segments, the 
genital segment being fully as large as the other two combined.

Antennules short, tolerably stout, and tapering towards the distal end; first two joints large and together equal to more than half the entire length of the antemnule; the curved spine at the distal end of the second joint much smaller than the spine similar to it on the antennules of Eudactylina acuta, and the strong, elongate, nearly straight spine at the distal end of the third joint in that species wanting here. Antennæ somewhat similar to those of Eudactylina acuta, but the stout spines on the first and second joints wanting. Second maxillipeds cheliform, other mouth-appendages similar to those of the species mentioned above.

The inner ramus two-jointed in all the four pairs of thoracic legs; the outer ramus of the first pair consisting apparently of only one joint, or of two subequal and coalescent joints, those of the next three pairs appearing to be composed of three joints, but the articulation between the second and third joints not so distinct as that between the first and second; in the first pair the inner ramus is provided with a number of short but stout spines chiefly on the exterior aspect, and the outer fringed with minute setæ; a small spine also springing from a notch near the middle of the outer margin and two or three small setæ from the distal end. The inner ramus in the second pair somewhat similar to, but rather stouter than, the inner ramus of the first pair ; the outer ramus three-jointer, but the second and third joints appearing to be coalescent; both rami fringed on the exterior edge with small prickles, the outer margin of the first basal joint, which is somewhat expanded, forming a rounded gibbose projection, also fringed with similar prickles, which are scattered sparingly over portions of all the joints. The remaining two pairs somewhat similar in structure to the second but rather more robust and less spiniferous. The fifth pair resembling those of Eudactylina acuta, but differing slightly in their for'm

VOL. I. 
and armature. Caudal rami moderately stout, fully as long as the last abdominal segment; two short spines springing from the outer margin of each ramus and three from the apex, the middle seta being the longest. Length about $2 \mathrm{~mm}$. Colour similar to that of the gills of the fish.

No males have been met with.

Habitat.-Parasitic on the gills of the piked dogfish or spur-dog, Squalus acanthias Linn. ( = Acanthias vulgaris Risso). Beaumaris Bay, Anglesey, September 1901, and other parts of the Irish Sea (A.Scott).

This Eudactylina is frequent on the gills of Squalus acanthias captured in the Irish Sea, and it may probably also occur on Scottish specimens of the same fish. Eudactylina acuta has been recorded from both the angel-fish and the piked dog-fish by van Beneden and Dr. Canu, but though the Eudactylinx obtained by these authors from the two fishes mentioned may belong to the one species, those found parasitic on the dog-fishes taken in Beaumaris Bay, \&c., certainly differed from the specimens obtained on angel-fishes captured on the English and Scottish coasts and examined by us.

\section{Eudactylina similis T. Scott.}

(Plate XXXVII, figs. 4, 5 ; Plate XXXIX, figs. 1-17.)

1902. Eudactylina similis T. Scott. (114) p. 295, pl. xii, figs. 1-19.

Female.-First cephalothoracic segment about one and a half times as long as the next, but the length of that segment; and of the two that follow, nearly the same; the last segment rather smaller than any of the others. Abdomen, including the genital segment, short, being only about one-third as long as the cephalothorax.

Antennules stout, and somewhat similar in structure and armature to those of Eudactylina acuta, but the two principal spines have each a fringe of minute prickles along the upper edge, and the penultimate joint is proportionally shorter; antennæ tolerably stout, elongated, and composed of four articulations, the first and second joints each provided with a stout but 
moderately short spine on the inner aspect, while the end joint bears two curved spines which are stout and claw-like; the second joint rather shorter than the first or third, and the terminal one very small. Mandibles slender and moderately elongated, with the distal half of the end joint serrated on the inner edge. Maxillæ small, bilobed, principal lobe stout, rather longer than broad, and provided with apical setæ of unequal length, one being nearly twice as long as the others; secondary lobe elongated, narrow, and bearing a moderately long apical seta. First maxillipeds small, three-jointed, and furnished with a short but rather stout terminal claw. Second maxillipeds tolerably large and strongly chelate; the end joint considerably expanded and its postero-lateral corners more or less produced, one of them extending into a spoon-like process, while to the other is articulated a strongly-curved claw, the apex of which impinges against the spoon-like process of the opposite angle, thus forming an effective grasping organ.

First pair of thoracic legs somewhat similar to those of Eudactylina acuta except in the following particulars: the second basal joint is furnished with two small but stout spines on the inner distal angle instead of a fringe of stout marginal spinules; the first joint of the outer ramus is proportionally considerably larger than either the second or third joints, the inner ramus is more slender, and the articulations are more unequal. The second pair are similar in structure to the same pair in Eudactylina acuta, but the outer ramus is proportionally and distinctly larger. 'The third and fourth pairs are somewhat similar in the two species; the fifth, however, are larger and proportionally broader than those of the species named, the length does not greatly exceed the width, and there is also a corresponding difference in their outline. Caudal rami about twice as long as the anal segment of the abdomen, and moderately wide but becoming narrower towards the apex, each bearing three small spiniform 
setæ-one at the apex and two on the lower half of the outer margin. Length about $3 \mathrm{~mm}$.

Male.-The male is smaller than the female, the body is more slender, and the abdomen is about as long as the cephalothorax. Antennules tolerably stout and composed of about seven articulations; the first and second joints are short but considerably dilated, the second is provided with a stout and strongly curved spine which springs from the upper distal angle; the remaining joints are all nearly of equal width and much narrower than the basal joints, the third joint is about as long as broad, the fourth and fifth are very short, the sixth is rather longer than the fourth and fifth combined, while the end joint is nearly three times the length of the sixth; the third and fifth joints are each furnished with a stout and moderately long straight spine, and a shorter spine also occurs on the distal end of the sixth joint, while the last joint is armed with a strong terminal hook and a slender sensory filament. Antennæ and mouth-appendages like those of the female except that the second maxillipeds are not chelate but provided with a simple terminal claw. The first four pairs of thoracic legs have both rami three-jointed, but the articulation between the second and third joints of the outer ramus of the first pair is not clearly defined; the inner ramus of the second pair is provided with a tolerably elongated and slightly curved spine which springs from the inner distal angle of the first joint; the outer ramus of the second pair is normal in structure. Both rami of the third pair are moderately slender and setiferous. Fifth pair somewhat similar to those of the female. Caudal rami narrow, each with two apical and one marginal spiniform setæ. Length about $2 \mathrm{~mm}$. Colour similar to that of the gills of the fish. Egg-strings moderately slender and elongated.

Habitat.-Parasitic on the gills of the starry ray, Raia radiata Don. The fishes on which this parasite was obtained were captured east of the Shetland 
Islands in May and off Aberdeen in November 1901 (T. Scott).

This species has a general likeness to Eudactylina acuta van Beneden, but differs from it in several respects.

\section{Eudactylina minuta T. Scott.}

(Plate XXXVII, figs. 6, 7 ; Plate XL, figs. 1-9.)

1904. Eudactylina minuta T. Scott. (115) p. 275, pl. xvii, figs. 1-11.

Female--Body slender; the cephalothorax about four times as long as the abdomen; the first cephalothoracic segment scarcely equal in length to the next two segments combined; the last two segments of the thorax rather more dilated than the others; all the segments rough with minute scattered hairs, especially along the dorsal aspect.

Antennules short, stout, and apparently consisting of five joints; the first three joints large and subequal, the fourth narrow and only about a third of the length of the preceding joint, end joint very small ; the second joint furnished with a stout and stronglycurved spine on the upper distal angle, two smaller spines springing from the distal half of the upper margin of the third joint; no terminal claw, but only a few apical setæ. Antennæ moderately elongate, three-jointed, and having a general resemblance to those of Eudactylina acuta; the second joint, which is about equal to the third one, having the lower distal angle produced downwards in the form of a short stout spine, while the end joint terminates in a strong curved claw. Mandibles and maxillæ somewhat similar to those of Eudactylina acuta. First maxillipeds moderately stout and armed with a stout and nearly straight terminal claw, while the end joint has a row of minute coarse denticles along its inner edge. Second maxillipeds large and strong and somewhat similar in structure to those of Eudactylina similis, but the extremity of the claw which impinges 
against the lower spoon-like process forms a rounded apical expansion. Both rami in the first pair of thoracic legs distinctly two-jointed and moderately stout, the inner ramus, which is larger than the outer, sparingly fringed with minute setæ and provided with two apical spines of unequal length; the outer and shorter ramus with a fringe of minute setæ on the outer margin of the first joint, the end joint bearing several spines round its outer margin and apex, the inner spine of moderate length but the others small. The second pair with a general resemblance to those of both Eudactylina acuta and Eu. similis; the inner ramus, which is distinctly three-jointed, considerably smaller than the outer one, and the first joint having a longitudinal row of small spines extending obliquely upwards from near the distal end of the outer margin, while the end joint bears two small apical spines of unequal length; the outer ramus stout, tolerably elongated and indistinctly three-jointed, end joint small, about as broad as long, and bearing a spiniform seta on its margin and two minute prickles on the rounded apex; two short spines, each with a thickened base, springing from near the distal end of the outer margin of the first joint, this joint being elongated and slightly arcuate; a pseudo-articulation may be noticed between the two short spines and extending partly across the joint. The third and fourth pairs nearly alike and resembling those of Eudactylina similis except that the inner rami have a number of scattered spinules on their outer aspect; the outer rami each rounded at the extremity and carrying a single elongated terminal seta ; they are also provided with a few small spines on the outer margin of the second and third joints, while a fringe of minute prickles extends along the margin of the first joint. The fifth pair, which are broadly foliaceous, ornamented with several transverse rows of minute spines and also furnished with three apical setæ. Candal rami short, about as long as the last abdominal segment, and bear- 
ing short, moderately stout apical spines, with two setæ on the outer margin. Length a little over $1 \mathrm{~mm}$. Egg-strings short, bearing a small number of moderately large ova. Colour reddish, resembling the colour of the gills of the fish.

No males observed.

Habitat. - Parasitic on the gills of a sting ray, Trygon pastinaca Linn., captured in the Dornoch Firth in October 1903 (T. Scott). The fish was sent to Dr. Fulton, Scientific Superintendent, Fishery Board for Scotland, who kindly placed it at our disposal.

\section{Eudactylina insolens T. and A. Scott.}

(Plate LXXI, figs. 1-12.)

Female.-Length exclusive of the furcal setæ 1.8 $\mathrm{mm}$. Body moderately robust and cylindrical, and having no appearance of segmentation between the third and fourth free thoracic segments as is usual in the members of the genus. The cephalic segment, seen from above, comparatively large and somewhat quadrangular in outline. Frontal margin broadly rounded and terminating on each side in a distinct knob-like projection. Lateral margins for some distance behind the knob nearly straight. First thoracic segment deeply constricted a little behind the middle. Second segment decidedly larger than the first, and its lateral margins somewhat inflated. Third segment large and cylindrical, tapering slightly towards the posterior end. Abdomen very short and three-jointed, rather less than one-seventh of the length of the entire animal. Genital segment comparatively large and swollen, and equal to the combined length of the second and third segments together with the furcal joints. Second and third segments short and of nearly equal length. Furcal joints short and about as long as the last abdominal segment, their length equal to twice the width. Each furcal joint furnished with one marginal and four apical setæ, which are very small. 
The frontal end of the cephalic segment and the second and third abdominal segments as well as the furcal joints have the dorsal surface covered with fine spinules.

Antennules short, stout, and six-jointed, resembling those of Eudactylina acanthii. The fourth joint very distinctly shorter than any of the others. The second joint furnished with a single stout curved spine.

Antennæ also similar to those of Eudactylina acanthii, except that the inner margin of the second joint is produced into two short teeth, and the terminal claw is much stouter.

Mandibles and maxillæ somewhat rudimentary in structure and very similar to those of Eudactylin aacuta.

The first pair of maxillipeds resembling those of the other members of the genus in general appearance, but the end joint is narrowly ovate in shape and its inner margin is furnished with a row of fine teeth. Terminal claw slender. The second pair of maxillipeds large and strong, and forming powerful chelæ. They are nearly similar in structure to those of Eudactylina minuta.

The first pair of feet biramose. Both branches short, stout, and two-jointed. The second joint of each branch much shorter than the first. The armature of the joints similar to that of the first pair of EudactyTina minuta. The second pair of feet decidedly different from the second pair of the other members of the genus known to us. Inner branch very short and threejointed. Outer branch also three-jointed but having a distinctly uncinate appearance and being about three times the length of the inner branch. The first joint of the outer branch large and swollen; equal to four times the combined length of the second and third joints. The second joint short and wide. The outer margin produced into a bluntly-rounded point. The third joint very short and narrow, and appearing to be loosely articulated to the second joint. It requires some care to detect it, as it appears to be easily folded over the surface of the second joint. The outer margin 
of the first joint strongly chitinized. The third pair of feet with the branches of nearly equal length and both branches three-jointed. The fourth pair of feet with a three-jointed outer branch and a two-jointed inner branch. The first joint of the outer branch large and swollen. The second and third joints short and of nearly equal length. The inner branch about half the length of the outer one and its two joints of nearly equal length. The fifth pair large and foliaceous and similar to those of Eudactylina minuta, except that there are no spinules on the surface.

Habitat.-Four specimens, all females, were found on the gill filaments of a male tope, Galeorhinus galeus, captured in the vicinity of King William Bank, off the north of the Isle of Man, Irish Sea, April 1912. The topes from which Eudactylina insolens and Kroyeria cineata were obtained, were caught in the trawl of the Lancashire and Western Sea Fisheries steamer, and landed at Piel, Barrow-in-Furness, along with other material, by Captain Wignall.

We were inclined at first to regard this Eudactylina as a form of Eudactylina acanthii, but a close examination showed that there were decided differences. The strong uncinate appearance of the long outer branch of the second pair of feet can be easily seen by examining the entire animal when lying on its side. 'That character, along with the differences in the structure of the first, third, and fourth pairs of feet, readily separate Eudactylina insolens from Eudactylina acanthii or any of the other members of the genus. T'he incomplete segmentation of the thorax, which gives the species only three free segments instead of four, may be abnormal and due to uncompleted development, but as the whole of the appendages appear quite normal we prefer in the meantime, in the absence of further material, to regard the form as distinct.

\section{Family iv. Phinchthyide.}

Female.-Body elongated, more or less segmented but without articulated locomotive appendages. Frequently furnished with lateral processes, which may 
be slender and flexuose, or in the form of spines. Antennæ and mouth-organs more or less rudimentary.

Male.-Body slender, distinctly segmented, and furnished with several cephalothoracic appendages, including antennules and antennæ; first and second maxillipeds and two pairs of thoracic legs all biramose; the first abdominal segment also sometimes provided with a pair of limbs. The first maxillipeds with strong terminal hooks forming powerful grasping organs. Abdomen usually composed of about eight segments.

Habitat.-The species belonging to this Family occur free in the mucus canals and sinuses of various fishes.

\section{Genus PHILICHTHYS Steenstrup, 1861.}

Female.-Head small, rounded. Body elongated and distinctly segmented; no dorsal plates, but the body, including the head, furnished with a number of lateral and ventral processes, moderately slender, and more or less curved inwards upon the ventral aspect. The egg-strings, which are of moderate length and thickness, extending alongside the body, and are partly enclosed and supported by the curved lateral and ventral processes.

There is in the female a single median eye-spot.

Male.-The male is much smaller than the female. The body is slender and distinctly segmented. The anterior part of the body consists of three segments, the first moderately large and bluntly rounded in front, the other smaller. 'T'he posterior portion is also segmented, very narrow, and considerably longer than the front part.

Antennules slender, composed of six articulations; antennæ two-jointed and provided with two hook-like setæ. The first maxillipeds moderately large, the second feeble.

Only one species is known. 


\section{Philichthys xiphiæ Steenstrup. \\ (Plate XLV, figs. 2, 3.)}

1862. Philichthys xiphiæ Steenstrup. (126) p. 295, pl. ii.

1864. Philichthys xiphize Ber'gsöe. (17) p. 87, pl. 13.

1877. Philichthys xiphiæ C. Vogt. (142) p. 29, pl. ii, figs. 13-15.

Female.-Body elongated and somewhat tumid, and having a rugged or coarse appearance; consisting of numerous segments and furnished with many appendages which vary in shape and size. Anterior portion of the cephalothorax consisting of three small segments, the one in front being extremely minute; a minute median eye-spot present on the dorsum of the second segment and a mouth-aperture beneath; the body immediately posterior to this front portion of the cephalothorax becoming more tumid and expanding equally on each side so as to form a nearly circular disc, the width of which is fully more than a third of the entire length; the remaining portion of the body for the most part subcylindrical and composed of numerous annulations, the penultimate segment small and only about half the width of the preceding one ; the anal segment broadly subtriangular and with two small knobs on the dorsal aspect, one on each side of the median line, and a blunt-pointed, finger-like process extending backwards from the middle of the posterior margin. Genital segment the sixth from the posterior end.

Body furnished with about fifteen appendages on each side, a few ventral but most of them lateral and all soft and uniarticulate, those on the posterior half of the body more or less incurved and hook-like. Egg-strings tolerably elongated and thick, attached to the genital orifices by the middle, extending forward as well as backward along the ventral aspect, and enclosed and supported by the curved lateral and ventral processes; the egg-strings not extending beyond the posterior end of the body. Colour pale purple, consisting of numerous minute purple spots on a white ground. Length varying from 6 to $36 \mathrm{~mm}$.-(Bergsöe.) 
Male.-Slender, elongated, becoming gradually attenuated posteriorly. Body distinctly segmented, ring's free and mobile. First segment of the cephalothorax scutiform, about as broad as long and equal in length to the next two segments taken together; third segment larger than the second and armed with a strong, slightly curved spine on each postero-lateral angle. Abdomen slender; anal segment longer and narrower than any of the preceding segments. Caudal rami very slender, elongate, rather shorter than the anal segment, and provided with two apical setæ.

Antennules very slender and consisting of six indistinct joints. Antennæ moderately stout, two-jointed, and furnished with two terminal, slightly hooked setæ. In the first maxillipeds the basal part is greatly enlarged and bears strong claw-like terminal spines; the second pair are small and feeble. Locomotary legs two pairs, short and biramose; both pairs have the outer ramus two- and the inner one-jointed; the rami are subequal in length but the outer ramus is rather more robust, and the proximal joint is very short; both pairs are liberally supplied with spines and setæ. Length about $4 \mathrm{~mm}$.

Habitat.-Living freely in the mucous canals in the head of the sword-fish (Xiplicas gladius). On a sword-fish captured off Lowestoft in 1892 ('Cambridge Natural History,' vol. iv, p. 73, footnote).

Distribution.-Mediterranean. New Zealand (G. M. Thomson).

Dr. S. F. Harmer, who examined the sword-fish and obtained the specimens of Philichthys described above, has sent us the following note, which he kindly permits us to use :-

"Some years ago (1892), when examining a specimen of sword-fish which had been taken off Lowestoft, it occurred to me to look for Philichthys xiphix, which I readily found in the place in which it has been described as occurring, namely, in the frontal bones. . . . I speak from memory, but I think I am right in saying that one of the parasites was found in each frontal bone." - (S. F. Harmer.) 


\section{Tribe III. LERN EOIDA.}

Mouth usually suctorial. Thorax not articulated, or only obscurely so. Thoracic legs, when present, of a more or less rudimentary structure. Body sometimes, as stated by Baird, "very outré in appearance."* Egg-strings two, stout and of moderate length, or sometimes slender and greatly elongated and straight or more or less twisted. Male usually very small.

The species belonging to this tribe are all more or less permanently fixed upon their hosts ; but, as stated by Baird, it is in general " only the adult female of the Lernæidæ that we are in the habit of observing, and in an animal whose organs of motion and perception for the most part are merely rudimentary, and whose existence is strictly stationary, the manner of life must be very simple." $\dagger$ They are usually arranged under the three families Lernæidæ, Chondracanthidæ, and Lernæopodæ, which differ, and, for the most part, are characterized by the manner in which the parasites fasten themselves to the fish on which they live, which also presupposes corresponding differences in at least some of the other appendages, as well as in the relation of the sexes. (See remarks on Lernæa in the Introduction.)

The young Lernæa leaves the egg as a free-swimming nauplius, which, in general appearance, is very similar to the larva of Cyclops.

\section{Family v. LeRNæIDE.}

Body of the mature and fixed ovigerous female more or less cylindrical, and unsegmented but roughly divided into three parts-a globular head with anchorlike processes either simple or branched; a narrow, cylindrical, and sometimes more or less flexuous neck connecting the head with the posterior part of the body or genital segment; the genital segment usually more or less swollen, and straight or sigmoid. Egg-strings two, slender, elongated, sometimes twisted into two involved masses, or forming more or less regular spirals.

* ‘ British Entomostraca,' p. 307. $\dagger$ Op. cit., p. 318. 
In the young but sexually mature stage the Lernæidæ do not differ greatly from the preceding families. The sexually mature young are furnished with two pairs of antennæ; the posterior pair usually end in strong hooks which project beyond the forehead; the maxillipeds are small and feeble, and the four pairs of thoracic legs are tolerably developed. 'I'he abdomen is usually rudimentary, and a median eye-spot is present. In the larval stages the young approximate more closely to Cyclops and are more or less free-swimming.

\section{Genus 27. LERNæA Linnæus, 1767.}

Head globular, slightly recurved, with the apex rounded or conical, and provided usually with three chitinous, more or less branched and horn-like appendages, two of them lateral and one median and dorsal. Thorax in the form of a moderately long, slender, and flexuous neck, which gradually becomes merged into the genital segment. Genital segment moderately enlarged, elongated and subcylindrical, and usually more or less abruptly bent upon itself, somewhat like the letter S. Egg-strings elongated and slender, and twisted into involved roundish masses under the posterior portion of the genital segment. Several of the cephalothoracic appendages becoming, in the fixed stage of the female, degenerate and rudimentary or obsolete; the first maxillipeds however retain their form, and are furnished with terminal hooks; the four pairs of thoracic legs are also persistent, and may be seen on the ventral aspect behind the subglobular head with the aid of a low-power objective.

The various species of Lern: $a$ are securely anchored to the host by the cephalic horns.

\section{Lernæa branchialis Linnæus. (Plates XLII \& XLIII.)}

1767. Lernæa branchialis Linn. (78) vol. i, pt. 2, p. 1092.

1850. Lernæa branchialis Baird. (4) p. 344, pl. xxxv, fig. 12.

1900. Lernæa branchialis T. Scott. (112) p. 161, pl. vii, figs. 11, 12.

1901. Lernæa branchialis A. Scott. (108) p. 33, pls. iv and v.

Female.-Head apiculated or conical, slightly recurved and provided with strong, branching, horn-like 
appendages; neck narrow, of moderate length, and somewhat flexuose; genital segment usually tolerably elongated, somewhat swollen and tapering slightly to the bluntly-pointed distal extremity; also abruptly folded upon itself in the form of the letter s. Eggstrings long, slender, and twisted into roundish masses under the posterior portion of the genital segment.

Cephalothoracic appendages rudimentary or obsolete, except the first pair of maxillipeds, which are situated near the apex of the head immediately behind the mouth; the four pairs of thoracic legs situated at the proximal end of the neck, and being exactly as they exist in the cyclops stage, both in size and structure. The first and second pairs biramose and both rami biarticulate, but the inner ramus wanting in the third and fourth pairs while the outer is composed of two joints. The whole animal when stretched out, and exclusive of the cephalic horns and the egg-strings, measuring about $40 \mathrm{~mm}$., but the size varies to some extent. Colour dark red, due to the contained blood.

Cephalic horns usually fixed in the gill-arches of the fish, the tissue of which they simply penetrate when the animal settles on the host, and then become branched, thus securing a firm anchorage. The branches in this species assume a more or less dichotomous arrangement, and in this respect differ from the other species to be described.

Male.-The male is very small, and resembles the young female in general appearance. Having reached the cyclopoid stage it undergoes no further change, and is then sexually mature.

Habitat.-The female in the adult fixed stage is usually parasitic on the gills of various Gadoids, as codfishes, haddocks, and whitings, and is not uncommon; while young females with males attached to them may be found on the gill-filaments of flat-fishes such as the flounder, Pleuronectes flesus. The following are some 
of the localities where this Lernæa has been obtained: Dublin and Belfast Bays (W. Thompson). Polperro and Falmouth (A. M. Norman). Plymouth (BassettSmith). Various parts of the Scottish and Lancashire coasts (nob.). Coasts of Northumberland and Durham (Brady \& Norman). Four adult female Lernæa branchialis were obtained from the gill-arches of twenty-four Callionymus $l_{!} v^{\circ} a$ and one on the gill-arches of a Centronotus gunnellus which were captured in the Irish Sea in 1910 (A. Scott).

\section{Lernæa lusci Bassett-Smith.}

(Plate XLIV, figs. 1, 2.)

1896. Lernæa lusci Bassett-Smith. (6) p. 13, pl. iv, fig. 6 .

1904. Lernæa lusci T. Scott. (115) p. 277, pl. xvii, figs. 12, 13.

Female.-Horns of the cephalon unequally developed, stout, and not so branching as in Lernæa branchialis; very short, except the one which springs from the dorsal aspect of the cephalon, this branch, which is tolerably elongated, extends outwards at nearly right angles to the neck, and is narrow and linguliform with the margins irregularly lobed and reflexed; the other horns very short and terminating in one or two rudimentary branches. Neck moderately short and thick, merging posteriorly and directly into the genital segment; this segment being proportionally considerably swollen and at first abruptly reflexed and bent upon itself, except at the distal end, where, in marked contrast to Lernæa branchialis, it is only slightly curved. The twisted eggstrings are also proportionally less slender than those of that species.

The antennæ and other cephalothoracic organs appear to be somewhat similar to those of Lernæa branchialis. Length of the female represented by the drawing (Pl. XLIV, fig. 1) only a little over half an inch (or about $15 \mathrm{~mm}$.), measuring from the head to the end of the genital segment. Colour dark red. Habitat.-Parasitic usually on the gill-arches of 
brassies or whiting-pouts, Gadus luscus (Linn.). Found on the gills of this species of fish at Plymouth (Bassett-Smith). Found on the gills of a brassie captured 10 miles off Aberdeen in January 1901 (T. Scott). Frequent on the gill-arches of brassies, Irish Sea ( $A$. $S \cot t)$.

A Gadus luscus sent from the Fish-Market at Aberdeen had one of these parasites adhering to it; in this example the head of the parasite was buried in the tissues in the abdominal region, behind and a little below the base of the pectoral fin-a somewhat unusual position for a Lernæa.

\section{Lernæa minuta T. Scott.}

(Plate XLIV, fig. 3.)

1900. Lernæa minuta T. Scott. (112) p. 161, pl. vii, fig. 13.

1904. Lernæa minuta, A. Scott. (109) p. 42.

Female.-Head moderately enlarged, not very clearly defined, and merging into the rather short and stout terminal appendage which is somewhat distorted and furnished with small marginal papillæ; two very short lateral appendages also present, with their ends obscurely bifurcate. Neck very short, narrow, and somewhat abruptly joined to the genital segment; this segment, which is sigmoid, having the proximal half considerably swollen, but tapering somewhat towards the bluntly-rounded and slightly-recurved extremity. Egg-strings as in Lernæa branchialis but rather stouter. Antennæ and other cephalic organs rudimentary or obsolete ; thoracic legs four pairs, small, but quite distinct and situated immediately behind the lateral cephalic horns. Length of the specimen represented by the drawing (Pl. XLIV, fig. 3) a little over $7 \mathrm{~mm}$. Colour dark red.

Habitat.-Parasitic on the gill-arches of speckled gobies, Gobius minutus Gmel. On Gobius minutus from the Solway in November 1899 (T. Scott); and on specimens of the same kind of fish captured in the Irish Sea $(A$. Scott).

VOL. I. 


\section{Lernæa lumpi T. Scott. \\ (Plate XLIV, fig. 4.)}

1901. Lernæa lumpi T. Scott. (113) p. 128, pl. vii, fig. 12.

Female.-Head globular, furnished with three very short, simple, spine-like horns, two of them lateral and one dorsal. Mouth seen as a small papilliform prominence on the ventral aspect. Head separated from the neck by a shallow constriction which is not an articulation. Neck long, moderately slender, slightly flexuose, and somewhat wrinkled. Genital segment, though rather stouter than the neck, proportionally less swollen than in Lernæa branchialis, neither is it sigmoid as in that species but doubled round in the form of a hook; a distinct constriction also present between that part where the egg-strings are attached and the caudal portion of the body. Clusters of eggstrings small and more or less twisted, as is usual in Lernæu. Antennæ and mouth-appendages appearing to be somewhat similar to those of other species of Lernæa. Length about two inches $(50 \mathrm{~mm}$.). Colour dark red.

Habitat.-Parasitic on the gill-arches of lumpsuckers, Cyclopterus lumpus. Found on a lumpsucker captured in the salmon nets at the Bay of Nigg near Aberdeen, 29th March 1900.

Only a single specimen of this somewhat curious parasite was obtained, though dozens of lumpsuckers have been examined; the head and a portion of the neck measuring about three-quarters of an inch penetrated the tissues of the fish.

The structure of this species seems in some respects to approach more nearly to that of Pennella than is the case with the adult Lernæa branchialis, the body is recurved to a much smaller extent, and the cephalic horns are greatly reduced in size; its hold on the fish might therefore be correspondingly weakened, but its fixation is rendered secure by having a larger proportion of the neck enclosed in the tissues of the fish.

It sometimes happens that the Lernæa dies while still attached to the living fish, and in that case, thongh the genito-abdominal part of the parasite's body disappears, the fish seems to be unable to get quit of the tougher and more 
chitinous neck and head which may remain fixed to the fish for a considerable time. It is interesting to note the difference in the form of the body of the two closely allied genera Pennella and Lernæa: in the one the body is elongated, cylindrical, and straight or nearly so; in the other it is bent back upon itself, forming one or two more or less abrupt loops.

\section{Genus 28. H压MOBAPHES Steenstrup \& Liittien, 1861.}

Parasites having a general resemblance to Lernæa.

Head rectangular, flattened, longer than broad and without lateral horn-like appendages. Two short, more or less distinct thoracic segments immediately posterior to the head, each bearing a pair of rudimentary bilobed appendages, followed by two pairs of legs, biramose and biarticulate. Neck elongated, the anterior end abruptly reflexed so that the head becomes pendulous, and near the flexure are two short, lateral, bluntly-pointed horns. Genital segment sigmoid, proximal half swollen, distal half narrower and with the apex bluntly pointed, a pair of short lateral processes occurring on either side over the origin of the egg-strings. Egg-strings very long and slender, but twisted up into regilar convoluted spires.

\section{Hæmobaphes cyclopterina (O. Fabr.). \\ (Plate XLIV, figs. 5-7.)}

1780. Lernæa cyclopterina O. Fabr. Fauna Grœnlandica, p. 337.

1822. Lernæocera cyclopterina Blainv. (24) vol. 95 , p. 376 .

1837. Lernæa cyclopterina Kröyer. (70) p. 502, pl. v, fig. 4 .

1840. Lernæa cyclopterina M. Edwards. (43) vol. iii, p. 529

1861. Hæmobaphes cyclopterina Steenstrup \& Lütken. (127) p. 405 , pl. xiii, fig. 30 .

1900. Hæmobaphes cyclopterinus T. Scott. (112) p. 162, pl. vii. fig. 14.

Female.-Head small, rectangular, without horn-like projections; two short, more or less distinct thoracic segments crowded behind the head, each furnished with a pair of rudimentary bilobed appendages. Two pairs of biramose legs with two-jointed rami also present, the rami being more or less setiferous. Neck long and slender, and bearing midway between the head 
and genital segment two short lateral horns or processes; at about this point a more or less abrupt flexure occurring, so that the head becomes pendulous. The proximal half of the genital segment somewhat swollen, the terminal part narrow and ending in a bluntly-pointed apex. A pair of short processes on each side of the genital segment over the origin of the egg-strings. Egg-strings, which form regular convoluted spires, situated at the termination of the swollen portion of the genital segment. Length about $12 \mathrm{~mm}$. Colour dark red, similar to that of Lernæu.

Habitat.-Parasitic on the gill-arches of various fishes. On the gills of a pogge, Agonus cataphractus, obtained by Mr. Peter Jamieson in the stomach of a large codfish landed at Dunbar, Haddingtonshire, in April 1891. Firth of Forth, on the gills of a pogge in February 1892, and on the gills of a butter-fish, Centronotus gunnellus, captured in 1901 (T. Scott). Irish Sea $(A$. S'cott).

The following other fishes are mentioned by Steenstrup and Lütken as hosts for this parasite: Cyclopterus spinosus, Cottus scorpius, C. bubulis, and C. grenlandicus, Sebastes norvegicus, Centronotus fasciatus, and Gadus merlangus.*

\section{Genus 29. HælMOBAPHOIDES 'T'. \& A. Scott.}

Syn. Hrmobaphes T. Scott (not Stp. \& Lütk.).

Resembling Hrmobaphes Stp. \& Lütk., but the head furnished with branched chitinic horns; neck very short, the posterior portion of the genital segment more produced, compressed, and expanded at the end.

\section{Hæmobaphoides ambiguus (T. Scott). \\ (Plate XLIV, fig. 8.)}

1900. Hæmobaphes ambiguus T. Scott. (112) p. 162, pl. vii, fig. 15.

Female.-Head not very clearly defined, and provided with branched cartilaginous horns, which are * ‘Parasitiske Copepoder,' p. 65 (1861). 
short and stout. Neck very short or nearly obsolete, genital segment flexuous; the anterior portion swollen as in Hrmobaples, but the distal portion narrow, and prolonged so that it at least equals in length the proximal part; this narrow elongated part also flattened, and, at the extremity, abruptly expanded, the margins somewhat irregular in outline and inflexed, and the lateral lobes at its proximal end moderately prominent. A distinct though quite shallow median groove extending along the dorsum of the swollen half of the genital segment. Egg-strings forming regular convoluted spires as in Hæmobaphes. Colour reddishbrown. Length about $11.5 \mathrm{~mm}$.

Habitat.-Parasitic on the gills of spotted dragonets, Callionymus maculatus Bonap. On spotted dragonets captured in the Solway Firth and in the Firth of Clyde.

In a sample of fifty-five Callionymus maculatus captured in the Firth of Clyde in October 1901, fifteen specimens of Hæmobaphoides ambiguus and eight of Chondracanthus ornatus were obtained. In most instances the specimens of the two species occurred singly and on different fishes, but in several cases two specimens of the same species or a specimen of each occurred on the gills of a single fish. For example, a spotted dragonet $73 \mathrm{~mm}$. in length had a Chondracanthus on one side and a Hæmobaphoides on the other ; another dragonet had a Chondracanthus and a Hæmobaphoides on the same side; a third had two Chondracanthus on the same side, while the other side was free of parasites; and a fourth had a Hæmobaphoides on each side but no Chondracanthus. It was also noticed that when only one parasite occurred on a fish it was frequently on the right side-the fish resting on its ventral surface and with its head toward the observer. It was further noticed that though seventeen specimens of the common dragonet (Callionymus lyra) captured at the same time and place were examined, no parasites were observed on them.

\section{Genus 30. PENNELLA Oken, 1815.}

Female-Body greatly elongated and slender. Head tolerably large, globose or nearly so, studded with minute tubercles and usually provided with horn- 
like appendages which extend obliquely backwards or at nearly right angles to the median line of the body. Thoracic region forming a more or less elongated and slender neck. Anterior portion of the genito-abdominal region elongated and moderately stout, and bearing near its distal end two tolerably long egg-strings. The terminal or caudal portion of the region more or less distinctly annulated and carrying along its ventral surface numerous fascicles of bristlelike and more or less branching appendages.

Antennules short, small, setiferous. Antennæ small, uncinate. Mouth-aperture near the anterior end on the ventral aspect. Thoracic legs four pairs, situated close behind the head and with only a small interval between each pair. The first and second pairs biramose, but the others one-branched; the rami all two-jointed, and all the thoracic limbs small.

In the immature Pennella the head is narrow and subcylindrical, and the horns are usually wanting. Both pairs of antenna though small are quite distinct, the second pair are provided with strong terminal claws and form effective grasping organs; the second maxillipeds are also stout and strongly clawed; a considerable space intervenes between these appendages and the thoracic legs.

"Male minute and not elongated" (Bassett-Smith).

M. Edwards remarks that the male is very small, nearly spherical, and possesses anteriorly a conical sucker, furnished with a few styliform appendages: and that on the inferior aspect there are two pairs of very large subcheliform claws by means of which it is enabled to hang on to the female.* We have not seen the male.

\section{Pennella orthagorisci E. P. Wright.}

(Plate LI, fig. 2.)

1829-1843. Pennella filosa Guérin-Méneville. (55) p. 11. pl. ix, fig. 3. 1861. Pennella filosa Steenstrup \& Tïitken. (127) pl. xiv, fig. 31.

1870. Pennella orthagorisci E. P. Wright. (150) p. 42. pl. i, figs. 1-6.

* 'Hist. Nat. Crust.', vol. iii, p. 522. See also G. M. Thomson, 'Trans.

New Zealand Institute,' vol. xxii, 1889, p. 368. 
1889. Pennella orthagorisci Giard. (50) p. 82.

1899. Pennela filosa Bassett-Smith (part). (8) p. 483.

1905. Pennella filosa T. Scott. (116) p. 113.

1905. Pennella orthagorisci T. R. R. Stebbing. (124) p. 119.

1906. Pennella filosa Norman \& T. Scott. (88) p. 216.

1908. Pennella filosa Cuvier? A. Brian. (21A) p. 8, text-figs. 2 \& 3.

1910. Pernella orthagorisci T. R. R. Stebbing. (125) p. 256.

Female.-Body elongated and slender; head moderately large, globose or nearly so, and provided with three horn-like appendages on the ventral aspect; the middle horn very small and rudimentary but the others of moderate size and projecting obliquely backwards. Neck elongate, slender, smooth, and equal to about one third of the entire length of the animal. Genital segment moderately stout and about as long as the neck; obscurely annulated and bearing at the distal end two long and very slender egg-strings. The terminal segment, or post-abdomen, which is fully balf as long as the genital segment, bearing along the ventral side fascicles of branching cartilaginous appendages, each fascicle dividing into two or three principal branches, which are again subdivided irregularly and in a bifurcate manner into long slender filaments, but including also a few which are short or undeveloped. Colour of the animal blood-red. Length 90 to $100 \mathrm{~mm}$. ( $3 \frac{1}{2}$ to 4 inches).

Habitat.-Parasitic usually on the short sun-fish, Orthagoriscus mola.

The Rev. A. M. Norman, whose kindness we have experienced on numerons occasions, has permitted us to examine and figure a Pennella sent to him many years ago (about 1862) by Thomas Edward of Banff. The specimen was found on a short sun-fish captured in the Moray Firth, and is referred to in Smiles' Life of Edward among the numerous other natural history records at the end of that work, under the name of Pennella fibrosa, that name being no doubt a misprint for "filosa"; unfortunately this specimen wanted the head. Some years previous to the publication of Smiles' Life of Edward, Dr. E. P. Wright described under the name of Pennella orthagorisci specimens found on short sun-fish captured in Cork Harbour in 1869*; he also in

* ‘Ann. \& Mag. Nat. Hist.,' ser. 4, vol. v, p. 42, pl. i, figs. 1-6 (1870). 
the same paper states that Dr. Baird informed him that he had "examined a specimen of Pennella from a sun-fish captured at Megavissy, Cornwall, which he (Dr. Baird) refers to P. filosa Linn." We have little doubt that the specimens obtained at the places mentioned were all referable to the same species.

The name Pennella filosa sometimes applied to the sun-fish parasite appears to have been given to it under the supposition that it and the swordfish Pennella were identical; thus far, however, there is no satisfactory evidence to show that they are so, and, till such evidence is forthcoming, the name Pennella filosa (Limn.), as pointed out by Steenstrup and Lütken, should be retained for the form found on the swordfish. Percival Wright's Pennella orthagorisci should also for similar reasons be accepted for the Pennella of the sun-fish. The Rev. T. R. R. Stebbing, in Part III of his work on "South African Crustacea" (1905), in a short discussion on Pennella, remarks that "the description given by Limnæus can scarcely be said to have any specific value apart from the name of the host, so that no injury is done him by leaving his specific name in abeyance until a Pennella infesting a Xiphias has been again observed. For the parasite of the sun-fish an appropriate name is available, which appear's to have escaped recent attention." *

In January 1908, M. Alexandre Brian published an interesting paper entitled "Note préliminaire sur les Copépodes parasites des poissons provenant des campagnes scientifiques de S.A.S. le Prince Albert $1^{\text {er }}$ de Monaco ou déposés dans les collections du Musée Océanographique." This Note forms Bull. No. 110 of the Oceanograplical Institute. The author describes with illustrative figures an adult, and several immature, female Pennelle under the name of "Pennella filosa Cuvier" which were obtained on a sun-fish captured in lat. $39^{\circ} 56^{\prime} 10^{\prime \prime} \mathrm{N}$., long. $34^{\circ}$ W., 19th July 1887, and which seem to be identical with Wright's $P$. orthagorisci. He also describes a "Pennella sp.?" A single adult obtained "dans la peau du ventre d'un Xiplias gladius" captured at Saint-Jean-sur-Mer, 11th March 1905. May this Pennella not be referable to the species described by Linnæus? It is more than twice the size of the adult female recorded from the sun-fish; the shape of the head and the form and size of its two horn-like appendages are also very different. The length of this specimen is described as 212

* 'Marine Investigations in South Africa,' "South African Crustacea," pt. iii, p. 118. 
millimetres (= about $8 \frac{1}{2}$ inches), whereas the adult female from the sun-fish is only 93 millimetres (about $3 \frac{5}{8}$ inches). 'The head of the young female of the sun-fish Pennella, as shown by Brian, is narrow and subcylindrical, fully three times longer than broad, and the horn-like processes are wanting; the abdominal appendages are also more or less rudimentary, and the posterior annulations appear to be more distinct.

The free-swimming larvæ of Pennella have a close resemblance to those of Lernæa branchialis and exhibit the near relationship between these genera. Dr. Al. Mrazek, in a paper "Ueber Bacculus Lubb. und Hessella Br. Ein Beitrag zur Anatomie der Lernæiden," * gives a detailed description of the anatomy of these larval forms.

\section{Pennella balænopteræ Koren \& Danielssen.}

Specimens of a giant species of Pennella found attached to a finner whale (Balænoptera musculus (Linn.)) were presented to Sir William Turner, F.R.S., Edinburgh, by Mr. Chr. Castberg, the manager of a Norwegian Whaling Company which has a fishing-station at Ronasvoe, in the north of Shetland. A full and interesting description of the species, illustrated with four plates, is published by Sir William Turner in the "Transactions of the Royal Society of Edinburgh,' vol. xli, Part 2 (No. 18), 1905.

This somewhat remarkable species does not come within the scope of a Monograph devoted to the parasites of fishes, but we nevertheless refer to it here on account of the author's interesting remarks on the history of the peculiar genus to which the species belongs, and becanse the description given of the species is also generally applicable to the one found on the sun-fish.

'The largest specimen obtained by Sir William 'Turner measured $294 \mathrm{~mm}$. (nearly $11 \frac{1}{2}$ inches) in length, but, as the author remarks, even larger specimens have been recorded by Koren and Danielssen; one of these is said to have measured $320 \mathrm{~mm}$. (12 $\frac{1}{2}$ inches) in length. In this species the head is provided with three slender chitinous horns of unequal length which extend horizontally outwards at nearly right angles to the body, the dorsal horn being usually the shortest; and in this and a few other respects Pennella balænopteræ differs from the sun-fish parasite. It seems however to be still a moot-point whether all these different Pennellæ are to be regarded as valid species.

* 'Sitzungsberichte d. königl. bohm. Gesellsch. d. Wiss.,' Math.-nat. Classe (1895), xliv, pp. 1-17, 2 plates. 
Another Cetacean Pennella, P. crassicornis Steenstrup \& Lütken, was found attached to a bottle-nose whale (Hyperoodon rostratus (Müll.)) captured south of the Faroës in 185j.* In this form the horn-like appendages of the cephalon are short and rather stout, and the whole animal is much smaller.

\section{Genus 31. LERN ÆOCERA Blainville, 1822.}

Body long and slender: head not distinctly defined, provided with horn-shaped appendages which are simple and more or less symmetrical in form. Mouth situated at the apex of a small conical lobe in the median line and projecting slightly forward of the base of the lateral horn-like appendages. Genital segment much elongated, becoming more or less thickened posteriorly, and somewhat curved at the distal extremity. Abdomen very small or obsolete. Egg-strings straight and of moderate length.

\section{Lernæocera cyprinacea (Linn.). \\ (Plate L, figs. 1-5.)}

1761. Lerna cyprinacea Linn. (77) vol. ii, No. 2100, pl. xi, fig. 2. 1783. Lernæa cyprinacea Barbut. (5) vol. i, p. 3, pl. vii, fig. 3.

1783. Lernæa (!) esocina Hermann. (61) vol. xix, p. 44, pl. ii, fig. 6.

1822. Lernæocera cyprinacea Blainv. (24) vol. xev. p. 377.

1832. Lernxocera (?) cyprinacea Nordm. (89) p. 123. pl. vi, figs. 1-8.

1840. Lernxocera (?) eoscina M. Edwards. (43) vol. iii, p. 527, pl. xl, figs. 13-15.

1840. Lernsocera cyprinacea idem. (43) vol. iii, p. 527, pl. xl, fig. 16.

1850. Lerneocera cyprinacea Baird. (4) p. 343, pl. xxxv, fig. 13.

1868. Lernxocera (?) esocina Claus. (34) vol. xxxi, p. 530.

Female.-"Head furnished with four horn-shaped appendages, which are somewhat long and slender. The two outer or posterior are bifurcated; the anterior simple.

"The thorax is very slender anteriorly, forming a long neck, but becomes much broader posteriorly, and when it terminates in the small abdomen, appears obliquely truncate. The ovigerous tubes are cylin-

* 'Bidrag. til Kundskab om detaabne Havs Synltekrehs og Lernæer,' p. 76 (separate copy), 1861. 
drical and rather long. The length of the whole animal is about eight lines."

"Hab.-Found on the sides of the carp, bream, and roach in many of our ponds and rivers in great abundance" (Barbut). "I have not seen any specimens of this species" (Baird, 'Entomostraca,' pp. 343, 344).

As we have not been able to obtain specimens of this Lernæocera, Dr. Baird's description and remarks are here reproduced. Fig. 5 on $\mathrm{Pl}$. L is also reproduced from his work.

Dr. Baird does not include Hermann's Lernæa esocina in his list of synonyms, but seems to regard it as a different species. He says: "Linnæus was the first who noticed any of the animals belonging to this genus. In his 'Fauna Suecica,' 1746, he describes a species found in Sweden on a carp; a species which Barbut, in 1783, ascertained to be British. Hermann also, in 1783, describes and figures another species, and several have since that time been added to the list. . . The genus, as established by Blainville, contains two species, which have been separated from it by Kröyer and M. Edwards; but still it has been retained in a restricted sense by all succeeding authors." M. Edwards apparently recognizes the two species, Lerneocera cyprinacea and L. esocina; ; Kröyer (1863) on the other hand does not mention either, but records Lernæocera phoxinacen Kollar, and describes two n. spp. from American waters.

Linnæus, after giving a brief description of his Lernæa cyprinacea, adds, "Habitat in Piscinus frequens supra corpus Cyprini carassii" $\dagger$; and Pennant, in speaking of Cyprinus carassius, which he also calls the "Crucian Carp," says " it is common in many of the fish-ponds about London and other parts of the south of England but I believe is not a native fish." $\ddagger$

From the remarks of Dr. Baird it is evident that the Lernæa recorded by Barbut is the species described by Linnæus, and that it also was found parasitic on fishes belonging to the Cyprinidæ; probably on the "Karauschen" or crucian carps, which were according to Pennant common at that time in many fish-ponds about London.

Nordmann in 1832 records a Lernæocera cyprinacea, five specimens of which were found "in der unteren Kinnlade des Hechtes," or fresh-water pike, Esox lucins, a kind of fish very

* 'Hist. nat. Crust.,' vol. iii (1840), p. 527.

† 'Systema Naturæ,' ed. xii, vol. i, pars ii, p. 1093 (1767).

+ 'British Zoology,' vol. iii, p. 364 (1776). 
different from the Carp family ; and his figures of the parasites of this fish, while in general agreement with that of Dr. Baird, represent what appears to us to be a different species from the one figured by the English author. Nordmann's figures show a more robust animal, with shorter and thicker cephalic horns, the distal extremity is also more decidedly deflexed, and the ovisacs are short and saccate.* Probably this is the Lernxocera esocina of Hermann and not L. cyprinacea (Linn.). We prefer therefore to retain meanwhile Linnés species name, cyprinacea, for the Lernxocera recorded by Dr. Baird.

\section{Genus 32, LERN ÆENICUS Lesueu, 1824.}

Body elongated, slender, obscurely or non-segmented. Head somewhat expanded, sometimes produced into a cone-like process in front, and usually provided with two or three stiff cartilaginous horns, projecting outwards or more or less obliquely backwards. Thorax very narrow, forming a kind of neck, and merging posteriorly into the somewhat stouter abdomen. Abdomen without penniform appendages. Antennules small, obscurely biarticulate, and more or less setiferous. Antennæ small but strongly chelate, and similar to those of Pennella. Thoracic legs very small, and situated immediately behind the head, each pair slightly apart from the other; the first and second pairs biramous and the others uniramous, and all the rami two-jointed. Egg-strings long and slender.

\section{Lernæenicus sprattæ (Sowerby).}

\section{(Plate XLVI, fig.s. 1-5.)}

1806. Lerniea spratta Sowerby. Brit. Miscellany, vol. ii, p. 17, pl. lxviii.

1840. Lernæonema monilaris M. Edwards. (43) p. 525, pl. xli, fig. 5.

1850. Lerneonema spratta Baird. (4) p. 341, pl. xxxv, fig. 10.

1850. Lernxonema bairdi Salter. (106) (ser. 2), vol. vi, p. 86, pl. vii, fig. 1.

1865. Lernæonema monilaris Heller. (58) p. 248, pl. xxv, fig. 4.

1868. Lernæenicus spratta Olsson. (92) p. 46.

* This figure of Nordmann's is reproduced on Pl. L, fig. 1. If compared with Dr. Baird's figures of L. cyprinacea on the same plate (fig. 4), the difference referred to will be readily observed. See also Selago's figure, which resembles Baird's and is also reproduced on this plate (fig. 5 ). 
1900. Lernæenicus sprattæ T. Scott. (112) p. 161, pl. vii, figs. 7-10.

1907. Lernæenicus sprattix A. Scott. (111) p. 94, pl. ii, figs. 1-5.

Female.-Body elongated, slender; head somewhat enlarged, and provided with two stiff horn-like processes, one on each side and extending obliquely backwards. Thorax, between the head and the genital segment, slender and neck-like, with a number of minute constrictions, giving to this part of the body a moniliform appearance; genital segment moderately elongated and increasing somewhat in thickness posteriorly. Abdomen rudimentary and not very clearly defined, apparently destitute of appendages.

Antennules short, distinct, setiferous, indistinctly two-jointed, the end joint being shorter than the other; antennæ very short, stout, strongly chelate as in. Pennella; other mouth-organs somewhat rudimentary. Thoracic legs small, situated immediately posterior to the head; first and second pairs biramose, rami two-jointed; the next two pairs uniramose, the rami being also two-jointed. In fresh or living specimens the colour of the genito-abdominal segment is greenish. Egg-strings long and slender, usually exceeding the length of the body, which, exclusive of the egg-strings, measures about $18 \mathrm{~mm}$.

Habitat.-Usually found parasitic on the eyes of sprats, Clupea spratta, and sometimes also on other parts of the body. Occasionally more than one parasite will be found adhering to the same eye. London Market 1848 (W. Wing, see Baird). Youghal, Ireland (W. Thompson 1852). Observed on a sprat in Leith Docks 1890 (J. Scott). Not uncommon on sprats captured along the Lancashire coast (A. Scott). One perfect specimen taken at Plymouth (Bassett-Smith).

A sample of six hundred sprats captured with the shrimp trawl off Blackpool in 1910 vielded fourteen Lernæenicus sprattr. The eye of one of the sprats examined had three specimens of Lernæenicus fixed to it. The head of the parasite is entirely buried in the tissues of the host, and cannot be removed except by dissection. 'The parasite when fixed to the eye appear's to cause partial or total blindness. 


\section{Lernæenicus encrasicola (Turton).}

(Plate XLVI, figs. 6--).)

1807. Lemæa encrasicola Turton. (141) vol. i, p. 137, No. 108.

1850. Lerneonema encrasicola Baird. (4) p. 341. pl. xxxv, fig. 11.

1868. Lernieenicus encrasicola Olsson. (92) p. 46.

1877. Lernæenicus encrasicola Richiardi. (102) vol. iii. fasc. i.

1907. Lernxenicus encrasicola A. Scott. (111) p. 93, pl. ii, figs. 6-9.

Female.-Closely resembling Lernæenicus sprattx, and may be easily mistaken for it. Among the more obvious points of difference are the following:-(1) The horn-shaped appendages of the cephalon, instead of pointing obliquely backwards, stand out at nearly right angles with the median line of the body. (2) "The neck is long and slender, quite smooth and destitute of the constrictions which mark so decidedly the preceding species" (Baird). (3) It is usually found attached to the body of its host, the head sometimes penetrating into the abdominal cavity.

The appendages of the cephalon and thorax do not appear to differ greatly from those of Lernxenicus sprattr. Length about $27 \mathrm{~mm}$.

No males of either species have been observed.

Habitat.-Parasitic on the anchovy, Engraulis encrasicholus, and sprat, Clupea sprotta. On a sprat captured at Youghal (R. Ball,W. Thompson). "Found attached to the bodies of Clupec encrasicholus and sprattus frequently, in Swansea Bay" (W. Turton). Attached to the body of a sprat (J. Doubleclay, British Museum).* A broken specimen, probably belonging to this species, was taken from a Clupea alosa at Plymouth (Bassett-Smith). On the eye of a young pollack at Falmouth (Cocks ; cf. 'Crust. of Devon and Cornwall’ by Norman and Scott, p. 216, 1906).

"A large catch of sprats was taken off Blackpool on 19th February 1906 by the Lancashire Fisheries Steamer, and a few hundreds of them were landed at Piel. A careful examination of these was made, and one sprat with two of the above mentioned parasites attached to it and another with one were found. The parasites were embedded in the

* 'These records are from 'British Entomostraca,' p. 342 (1850). 
tissues at the anterior end of the dorsal fin. On dissecting one of the specimens out, it was found that the head of it had penetrated into the visceral cavity" (A. Scott).*

M. Marcel Baudoin, in his article on the parasites of the sardine, $\dagger$ describes under the name of Lernæenicus sardinæ a form which he has found adhering to this Clupeoid. There is, as stated by Aflalo, a British Pilchard-fishery on the southwest coast, $\ddagger$ and the same fish has occasionally been captured in Scottish waters, $\S$ but no British specimen of this Lernæenicus has yet been observed. Though, however, many pilchards are captured each season, this Lernæenicus if present may be easily missed, or mistaken for the more common $L$. sprattæ. One of the more obvious characters of the species being the shape of the head, as this is buried in the tissues of the host, sometimes at the side of the eye as in Lernæenicus sprattre and sometimes near the dorsal fin, it is only by careful dissection that it can be obtained for examination. The neck next the head is extremely slender, and therefore the external portion of the parasite is easily broken off, while the head remains entirely concealed.

\section{Genus 33. TRIPAPHYLUS Richiardi, 1878}

Syn. Lerneonema, P. J. van Beneden (in part).

Female.-Body greatly elongated, slender, nonsegmented. Head rounded and provided with stiff cartilaginous horns. Thorax very slender, forming an elongated neck. Genito-abdominal segment narrow at the proximal end but becoming enlarged posteriorly and furnished with two long and slender distal processes. Antennules and other cephalic appendages somewhat similar to those of Iernæenicus.

Male.-Body divided into two nearly equal portions ; the anterior portion large and carrying three pairs of appendages; the cephalon rather obscurely defined, and the abdomen not so robust as the cephalo-thoracic portion. The cephalothoracic appendages also somewhat rudimentary.

* 'Report for 1906 on the Lancashire Sea-Fisheries Laboratory at the

University of Liverpool, and the Sea-fish Hatchery at Piel,' No. xv, p. 94.

† “Les parasites de la Sardine," 'Revue scientifique,' $5^{\prime}$ ser., vol. iii, No.

23, p. 715, with text-figures (1905).

+ 'Natural History (Vertebrates) of the British Isles,' p. 398 (1898).

'Fishes of the Firth of Forth,' by Dr. Parnell, pp. 320-322 (1838). 


\section{Tripaphylus musteli (P. J. van Beneden).}

(Plate XLV, fig. 6 ; Plate LI, fig. 1; Plate XLIX, figs 1-7.)

1851. Lerneonema musteli P. J. van Ben. (12) vol. xviii, p. 287, pl. No. 8, figs. $1-7$, o \& $\&$.

1851. Lerneonema musteli idem. (11) vol. xvi, p. 125, pl.6, figs. 11-14. 1877. Lerneonema musteli Vogt. (142) p. 69, pl. iii, fig. 11.

1878. Tripaphylus musteli Richiardi. (103) p. xx.

1885. Tripaphylus musteli Carus. (29a) Prodr. faunæ Mediterr., p. 372. 1899. Lernæenicus musteli Bassett-Smith. (8) p. 485.

1904. Lernæenicus musteli A. Scott. (109) p. 41.

1906. Tripaphylus musteli A. Brian. (21) p. 87.

Female.-Body greatly elongated and slender, nonsegmented and with the surface quite smooth. Head rounded and furnished with cartilaginous horns. Thorax very slender, rather weak and somewhat flexuous. Genito-abdominal portion narrow at the proximal end where it joins the neck, but becoming gradually enlarged from the front backwards, and assuming nearly the form of a spindle. Body provided posteriorly with two long slender appendages nearly equal in length to the genital segment; these appendages, though in communication with the bodycavity, have no connection with the egg-strings, which have their origin immediately behind the base of the prolongations referred to and are nearly twice their length.

Head with a considerable portion of the neck buried in the tissues of the gill-arch of the fish. Colour of the parasite deep red. Length as given by van Beneden: Body exclusive of the abdominal appendages $45 \mathrm{~mm}$; abdominal appendages $15 \mathrm{~mm}$. in length and the egg-strings $23 \mathrm{~mm}$. The body in its greatest width measures $3 \mathrm{~mm}$.- this specimen wanted the head. The specimen figured here (Pl. LI, fig. 1), which is also minus the head, measures $28 \mathrm{~mm}$. exclusive of egg-strings.

Male.-The male of this species has the body divided into two unequal portions: the anterior portion is large, and carries three pairs of appendages- 
viz. one pair of antennæ and two pairs of feet; the posterior is much more narrow, and rounded, and carries at the end two rounded tubercles which probably represent the fifth pair of feet; the body may also be divided into head, thorax, and abdomen. On the sides of the cephalic portion we distinguish a pair of setiferous antennæ showing feeble indications of articulation; the mouth is terminal and fringed with minute setæ. The mandibles and maxillæ are somewhat rudimentary. The two pairs of maxillipeds are comparatively well developed, and form prehensile appendages similar to what is found in the males of many of the sedentary female fish-parasites.

The thorax is dilated (or bulging), smooth and even on the surface; it carries two pairs of feet singularly formed, and nearly as dilated and elongate as the abdomen. The feet of both pairs are consolidated in all their length as the organs of adhesion in the females of the Lernéopodians; it is only at the end that they are divided. The anterior pair is biramose; the outer ramus is two-jointed, and is terminated by a double hook for clinging. The other pair is longer; the outer ramus shows three articulations terminated by two hooks, as in the outer ramus of the preceding pair, but on the base of the hooks is a small additional tooth which renders these organs of adhesion more effective.

It will be seen from the above description and the drawing Pl. XLV, fig. 6) that there are some of the Lernæan males considerably removed from the ordinary type.

Habitat.--Parasitic on the gills of the smooth hound, Mustelus vulgaris (Squalus mustelus). Irish Sea (A. $S($ cott). 


\section{Genus 34. REBELULA Poche, 1902.}

Syn. Lophura Kölliker (name preoccupied for a genus of birds).

Head subcylindrical, narrow, in the same straight line as the neck and furnished with two bilobed or slightly branched processes at its base.* Neck usually slender and elongated. Genital segment large, inflated, somewhat flattened dorsally, and having small, slightly obscure circular depressions on the dorsal and ventral aspects, and provided posteriorly with two bundles of filiform appendages, one on each side of the abdomen. Abdomen small and obscurely lobate. Egg-strings tolerably elongated, and containing numerous small ova.

\section{Rebelula edwardsi (Kölliker). \\ (Plate XLV, fig. 1; Plate LI, fig. 5.)}

1853. Lophura edwardsi Kölliker. (6Sa) Zeitschr. f. wiss. Zool., vol. iv, p. 359 .

1860. Lophoura edwardsi Claus. (30a) Würzburger naturwiss. Zeitschr., vol. i, p. 20.

1865. Lophura edwardsii Cornalia. (36a) Atti della Soc. Ital. d. Sci. Nat., vol. ix, p. 1, pl. i.

1902. Rebelula edwardsii Poche. (97) p. 20.

1906. Rebelula edwardsii Brian. (21) p. 90 , pl. xix, fig. 1 ; pl. xxi, fig. 5.

1908. Rebelula edwardsi Brian. (21a) p. 15, text-fig. 6, a, b.

Female.-Head subcylindrical, narrow, moderately short, and, with part of the neck, buried in the tissue of the host in the neighbourhood of the dorsal fin. Neck tolerably long and narrow. Genital segment stout, suborbicular, or pyriform, somewhat flattened dorsally, and provided posteriorly with two bundles of slender digitiform filaments, one on each side of the abdomen. Abdomen small, obscurely trilobed. Egg-strings tolerably elongated, containing numerous small ova, and springing from the base of the abdomen, inside the digitiform appendages.

The specimens examined by us were of a reddish

* The description of the head of Rebelula given in the definition of the genus is taken from complete specimens found on macrurid fishes captured in the Bay of Bengal and in the Malay Archipelago, and representing two apparently distinct species of this curious genus of parasites. 
colour, but they had been for some time in a preservative fluid. The smaller of two specimens measured from the posterior end of the neck to the extremity of the digitiform processes about $12 \mathrm{~mm}$., the other was about twice that size.

Habitat.-Parasitic on species of Macruridæ. One on a Macrurus (Lepidoleprus) color.hynchus Risso, capcaptured off the south-west of Ireland by H.M.S. 'Research' at Station I, depth 200 fathoms, 10th July 1899 (A. M. Norman).* One in a gathering collected by means of a small trawl, at a depth of 1448 metres in lat. $58^{\circ} 43^{\prime} \mathrm{N}$., long. $9^{\circ} 6^{\prime} \mathrm{W}$., 23rd August 1910 (Fishery Steamer 'Goldseeker'). Host doubtful : this specimen appears, in some way, to have become detached from its host. In both specimens the head was wanting.

The following measurements are from the specimen from the west of Scotland:--

Length of neck

Length of genital segment

Width of genital segment at widest

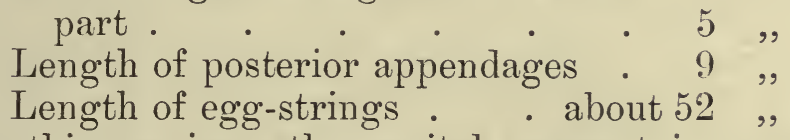

In this specimen the genital segment is somewhat different in shape, and rather more elongated than the other, but otherwise they are similar, and appear to belong to the same species.

Brian has recorded a female Rebelula $\dagger$ which was found adhering to a Macrurus about 14 inches in length captured lat. $45^{\circ} 13^{\prime} \mathrm{N}$., long. $3^{\circ} 06^{\prime} \mathrm{W}$., at a depth of 358 metres, in July 1903. This parasite, which he, with some doubt, ascribes to $R$. edwardsii, is not unlike the specimen from the south-west of Ireland described by us. He gives a figure of the specimen but was unable to show the head, as the anterior part was buried in the tissues of the fish; the visible portion measured about $12 \mathrm{~mm}$.

The author remarks: "J'ai cru devoir déterminer cette

* Canon Norman, with his usual kindness, permitted us to make a drawing of this specimen (see Pl. LI, fig. 5).

† 'Bull. de l'Institut Oceanographique,' No. 110, p. 15 (1908). 
espèce avec quelque doute, n'ayant pu examiner tout le corps, qui dans sa portion antérieure est caché et enfoncé dans les muscles du Macrurus. Les parties visibles du copépode comme l'abdomen et ses prolongements digitiformes montrent, cependant, des caractères spécifiques qu'on peut considérer comme probablement identiques à ceux de l'espèce bien connue : $R$. Edwardsi Köll., qui n'est indiquée jusqu'à présent que pour la Méditerranée." As we have indicated, there is apparently more than one species of Rebelula, but identification is difficult if the specimen is incomplete.

\section{Genus 35. SPHYRION Cuvier, 1830.}

\section{Syn. Lestes and Lesteira Kröyer.}

Head more or less expanded transversely, small and bulb-like but sometimes of considerable dimensions, and separated from the genital segment by a smooth and slender neck, cylindrical and moderately elongated. Genital segment of moderate size, smooth, ovate, subglobose, or bulbiform, and furnished posteriorly with two tolerably large bunches of vesicles resembling clusters of grapes, one cluster being on each side of the abdominal lobe. Antennules rudimentary. Thoracic limbs apparently suppressed. Egg-strings straight, tolerably elongated. Colour pale red. Male unknown.

The original definition of the genus by Cuvier is sufficiently correct, with the exception of his description of the posterior appendages which he calls faiscean de poils. The Rev. 'I. R. R. Stebbing remarks that these grape-like clusters "are appended to the genital segment probably with a branchial function." *

\section{Sphyrion lumpi (Kröyer). (Plate LI, figs. 3, 4.)}

1845. Lestes lumpi Kröyer. Danmarks Fisk, vol. ii. p. 217.

1863. Lesteira lumpi Kröyer. (71) p. 325, pl. xviii, fig. 5, $a-g$.

1869. Lesteira lumpi Steenstrup. (126a) p. 182, pl. ii, fig. 5.

1899. Sphyrion lumpi Bassett-Smith. (8) p. 489.

1901. Sphyrion lumpi T. Scott. (113) p. 128, pl. vii, fig. 13.

Female.-Cephalothorax rather small and scarcely

* 'Marine Investigations of South Africa,' Crustacea, pt. 1, p. 60. 
equal to a quarter of the entire length of the animal, somewhat cordiform or crescent-shaped, and consisting of two lateral projections directed slightly forward and expanded into rounded wing-like processes-one on each side of the small cephalon or head. A neck, tolerably elongated, slender and cylindrical, joining the genital segment to the anterior end of the body. Genital segment of moderate size, broadly ovate or obscurely heart-shaped and slightly flattened; the width, which is nearly the same as, or which slightly exceeds, the length, equal to fully one and a half times the width of the cephalothorax; its lateral margins boldly rounded and the posterior margin nearly straight; a small median lobe on the posterior margin representing the terminal part of the abdomen, and on either side of it a tolerably large cluster of vesicles resembling a bunch of grapes, each cluster fully half the size of the genital segment. Ego-strings straight and moderately elongated. Length of the animal exclusive of the egg-strings about $40 \mathrm{~mm}$.

The following measurements are taken from a fairly perfect specimen:-Length of head, $6 \mathrm{~mm}$, ; of neck, $15.5 \mathrm{~mm}$.; of genital segment, about $12 \mathrm{~mm}$.; appendages of genital segment, $7 \cdot 5 \mathrm{~mm}$.

Antennules small and feeble. Thoracic limbs apparently obsolete, mouth-organs rudimentary.

The male has not been observed.

Habitat.-An imperfect specimen was taken from a lumpsucker (Cyclopterus lumpus) captured in the nets of the salmon fishers at the Bay of Nigg near Aberdeen in April, 1900; and a fine, nearly perfect specimen was presented to one of the authors by Mr. Irvine of Aberdeen who obtained it on one of a number of catfishes (Anarrhichas lupus) landed at the Aberdeen FishMarket but captured in the North Sea, probably outside the Scottish area, by a Norwegian Trawler. It is from this specimen that the description given above was prepared. The Bay of Nigg specimen was minus the head, probably owing to the fish having been roughly 
handled; it also appeared to be somewhat immature, as the appendages of the genital segment were not fully developed; they resembled those of a young female represented by figure $5 \mathrm{c}$ on plate xviii of Kröyer's work, 'Bidrag til Kundskab om Snyltekrebsene' (1863). Kröyer's specimens of Sphyrion lumpi were found fixed on the tail of a Cyclopterus lumpus from Iceland.

A species from the sonthern hemisphere, Sphyrion lavigatum Guérin-Méneville, described by G. M. 'Thomson, New Zealand, and also recorded from South African waters by the Rev. T. R. R. Stebbing, exhibits a remarkable difference in the form and dimensions of the cephalothorax, which, unlike that of Kröyer's species, is distinctly larger than the genital segment, while its shape, instead of being regular, is more or less distorted.

The cephalothorax of Sphyrion, like that of Lernxa, Hæmobaphes, and other members of the family Lernæidæ, penetrates, and is wholly enveloped by, the tissues of the liost.

The nauplius of Sphyrion, as shown by Kröyer, is a freeswimming organism somewhat similar to that of Lernæa branchialis.

Dr. Bassett-Smith records, but somewhat donbtfully, the occulrence of Sphyrion lumpi at Dungeness. (Cf. 'A systematic Description of Parasitic Copenors found on Fishes,' p. 488.)

\section{Family vi. Chondracanthides.}

Female.-Body usually more or less incompletely segmented, sometimes furnished with outgrowths in the form of lobes or prolongations, and frequently with the head wholly or partially immersed in the tissues of the host. Antennules short, two- or threejointed, or rudimentary. Antennæ small and armed with simple but sometimes powerful terminal hooks. Mandibles falciform, expanded at the base, and tapering to the distal end, which is nsually more or less attenuated and incurved; furnished with two rows of minute prickles, usually marginal, which extend from 
the base to near the apex. Thoracic legs rudimentary and usually in the form of unsegmented lobes. Eggstrings two, usually short, and containing numerous ova, but sometimes elongated and more or less twisted.

Male.-Very small and adherent on the female by means of hooked appendages. Cephalothorax distinct; limbs more or less articulated. Abdomen segmented.

In the Chondracanthidæ the type of mandible is distinctly different from that of the Caligidæ or the Lernæopodidæ; the biting part is composed of a single morerately elongated piece, and is falciform in shape, broad at the base and tapering to the pointed and often attenuated distal extremity; these biting parts are articulated to a moderately stout base, and curved towards each other at an abrupt or almost a right angle, and both margins are fringed from the base almost to the apex with minute serratures. This type of mandible is rarely met with in species belonging to any of the other families described here.

Genus 36. CHONDRACANTHUS De la Roche, 1811.

Syn. Chondracanthus and Lernentoma Baird.

Female.-Head usually small, not articulated to the thorax, separated by a constriction which may be distinct or not clearly defined. Thorax short, moderately narrow, and indistinctly bisegmented. Genital segment proportionally large, slightly flattened, and divided usually into two portions by a transverse constriction, more or less distinct, but sometimes indistinct, and with the postero-lateral corners prolonged into narrow processes which may be short or moderately elongated. Abdomen very small, situated between the lateral processes and composed of one or two segments.

Antennules moderately large, more or less conspicuous in front and somewhat rudimentary in structure. Antennæ very short and armed with strong terminal hooks. Mandibles falciform, broad 
at the proximal end, but tapering to the more or less attenuated distal extremity; both margins fringed with minute prickles or teeth. First maxillipeds small and provided with a straight terminal spine which is sometimes serrated. Thoracic limbs two pairs, biramose; rami rudimentary. Caudal rami obsolete.

Male.-Very small. Cephalothorax considerably dilated. Abdomen small, more or less segmented. Maxillipeds fairly well developed, and fitted for grasping; other appendages somewhat rudimentary.

\section{Chondracanthus cornutus (O. F. Müller).}

(Plate XLVII, figs. 1, 2 ; Plate LII, fig. 5; Plate LIII, figs. 1-9.)

1777. Lernæa cornuta O. F. Müller. (85) p. 124, pl. xxxiii, fig. 1.

1815. Anops cornuta Oken. (91) t. iii.

1816. Entomoda cornuta Lamarek. (72) vol. iii, p. 233.

1822. Lernentoma cornuta Blainville. (24) p. 441. $5-10$.

1832. Chondracanthus cornutus Nordmann. (89) p. 111. pl. ix, figs.

1850. Lernentoma cornuta Baird.

(4) p. 328 , pl. xxxv, fig. 2.

1851. Chondracanthus cornutus P. J. van Beneden. (11) p. 108, pl. iv, figs. 1-4.

1863. Chondracanthus cormutus Kröyel: (71) p. 249, pl. xiii, figs. 7 a-S.

1877. Chondracanthus cornutus C. Vogt. (142) p. 78, pl. vi, figs. 4-8. 31.

1900. Chondracanthus cornutus T. Scott. (112) p. 164, pl. vii, figs. 19-

1906. Chondracanthus cornutus Norman \& T. Scott. (88) p. 217.

Female.-Head ovate, somewhat longer than broad; thorax narrower; genital segment rather wider than the head, moderately elongated, flattened, and usually with a constriction-sometimes indistinct-dividing it into two subequal portions ; the postero-lateral corner's of the segment produced backwards into straight and narrow prolongations, their length being rather less than the width of the segment. Abdomen very small, bisegmented and rather shorter than the lateral prolongations of the genital segment.

Antennules robust and tolerably large but showing scarcely any structure. Antennæ short and armed with strong terminal hooks. Mandibles stout, falciform, attenuated towards the distal extremity, and 
fringed along both sides with minute bristles. First maxillipeds with the basal part moderately stout, but the end joint rather slender, and its inner edge serrated. Thoracic legs short and very rudimentary. Length about $6 \mathrm{~mm}$.

Male.-The cephalothorax in the male is considerably enlarged, and apparently unsegmented ; dorsum boldly rounded; abdomen composed of three or four segments. Caudal rami small. Antennules conspicuous but showing little structure. Second maxillipeds armed with small but effective and claw-like terminal hooks. Length scarcely $0.5 \mathrm{~mm}$. ( $\frac{1}{50}$ of an inch).

Habitat.-Parasitic, usually inside the gill-covers of plaice (Pleuronectes platessa). The species is tolerably frequent, and has been recorded from various parts of the British coasts. In the drawing (Pl. XLVII, fig. 2), a male " $\mathrm{m}$ " is seen clinging to the female.

Some variation has been observed in specimens belonging to this species as shown by figs. 1 and 2 in Pl. XLVII, some being longer and narrower than others and with the thoracic legs less developed, but these seemed to be the only differences between them.

\section{Chondracanthus annulatus Olsson.}

(Plate XX, fig. 2; Plate XLVII, fig. 3; Plate LVI, figs. 8-10.)

1868. Chondracanthus annulatus Olsson. (92) p. 30, pl. ii, figs. 13-15.

1880. Chondracanthus læviraja Della Valle. (141a) Boll. Soc. Adriat. Sc. Nat., vol. vi, p. 73.

1900. Chondracanthus annulatus T. Scott. (112) p. 164, pl. vii, figs. 46-51.

1909. Chondracanthus inflatus Bainbridge. (3) p. 47, pl. ix, figs. 9-15.

1910. Chondracanthus annulatus Norman \& Brady. (87A) p. 156.

Female.-Body elongated, moderately narrow and cylindrical, about four times longer than broad, and only slightly flattened. Head small but well defined; the thorax also fairly well marked and the head and thorax combined equal to about one-third of the entire length of the animal. Genital segment, which constitutes the other two-thirds, showing a slight constric- 
tion near the middle, with the postero-lateral corners produced into short bluntly-rounded lobes; a small median projection on the dorsal aspect which conceals the proximal part of the abdomen. Abdomen, which is bisegmented, reaching to about the end of the lateral lobes, and imparting, a trilobed appearance to the posterior end of the genital segment.

Antennules considerably enlarged but showing very little structure, and bearing a few small apical spines. Antennæ short, stout, and armed with bluntly-pointed claws. Mandibles similar to those of Chondracanthus cornutus; maxillipeds also somewhat similar to those of the same species. Both pairs of thoracic legs short and rudimentary. Length about $14 \mathrm{~mm}$. Colour pale red. Egg-strings tolerably elongated.

Male.-The male of this species is proportionately larger than that of the one previously described; the cephalothorax also greatly enlarged. Antennules short, not very robust, uniarticulate and furnished with a few short marginal spines and a fascicle of tolerably long apical setæ. Antennæ short, stout, and armed with short but strong terminal hooks. Second maxillipeds strong, biarticulated, and provided with terminal claws. Other thoracic appendages rudimentary. Abdomen composed of three or four segments, but one or two are not very clearly defined. Length about $3 \mathrm{~mm}$.

Habitut.-Parasitic on the gills of large blue (or grey) skates (Raia batis), captured in the North Sea and landed at the Aberdeen Fish-Market (T. Scott). North Shields (Miss M. Lebour).*

\section{Chondracanthus soleæ Kröyer.}

\section{(Plate XLVII, fig. 4; Plate LIII, figs. 12-15.)}

1838. Chondracanthus solex Kröyer. (70) vol. ii, p. 139, pl. iii, fig. 4.

1863. Chondracanthus soleæ idem. (71) p. 256.

1900. Chondracanthus soleæ T. Scott. (112) p. 165, pl. vii, figs. 41-45.

1906. Chondracanthus solex Norman \& T. Scott. (88) p. 217.

* See Norman \& Brady's 'Crustacea of Northumberland and Durham,' p. 156 (1909). 
Female.-Body tolerably robust; head subtriangular, narrow in front, widest behind, its length scarcely equal to the width. Thorax short, composed of two fairly-distinct segments; the head and thorax combined, equal to rather more than half the length of the genital segment; this segment robust, somewhat flattened and divided by a distinct transverse constriction into two nearly equal portions; the posterolateral corners of the distal portion produced backwards into straight and narrow prolongations the length of which is more than half the width of the segment. Abdomen very small, biarticulated, and considerably shorter than the lateral prolongations of the genital segment.

Antennules uniarticulate, conspicuous, but not very robust, and furnished with a few minute subapical setæ. Antennæ short, stout, and ending in short claw-like spines. Mandibles and other mouth-appendages somewhat similar to those of Chondracanthus cornutus. Both pairs of thoracic legs tolerably elongated, but rudimentary in structure. Length about $8 \mathrm{~mm}$. Egg-strings about the same length.

Mrle.-The male of this species is very small and similar to that of Chondracanthus cornutus: ; the appendages are also similar except that the antennules have the basal joint considerably enlarged and subtriangular, while the end joint is very small and bears a few minute setæ.

Habitat.-Parasitic on the gills of the black sole (Solea vulgaris), and only occasionally on other flat fishes. Starcross, Devon, on a dab (C. Parker in Mus. Normanianum). On Solea milgaris, Plymouth (BassettSmith). Firth of Clyde (T'S Scott). Irish Sea (A. Scott).

\section{Chondracanthus fluræ Kröyer.}

\section{(Plate XLVII, fig. 5 ; Plate LIII, figs. 10, 11.)}

1863. Chondracanthus fluræ Kröyer. (71) p. 249, pl. xiii, figs. 7 a-d.

1900. Chondracanthus flume T. Scott. (112) p. 166, pl. vii, figs. 32-34.

Female.-The head and thoracic segments narrow 
and not so clearly defined as in Chondracanthus solex, and together scarcely equal to a third of the entire length of the animal. Genital segment robust, somewhat flattened, and about twice as wide as the thorax; a distinct transverse constriction dividing it into two subequal portions; the general outline of the segment broadly oval, its extreme length being about one and a half times greater than the width; the posterolateral corners of the distal portion produced into moderately short, narrow, arcuate, and slightly convergent lobes, enclosing between them the small biarticulated abdomen.

Antennules moderately robust and indistinctly biarticulated, with one or two subapical setæ. Antennæe short, and armed with small but stout terminal claws. Mandibles and other mouth-appendages somewhat similar to those of Chondracanthus cornutus. Thoracic legs rather small and rudimentary. Length about $5 \mathrm{~mm}$. Egg-strings about the same length.

Male.-Very small, and somewhat similar in size and structure to the male of Chondracanthus cormutus. Habitat.-Parasitic on the gills and inside the gillcovers of long rough dabs (Drepanopsetta platessoides Fabr. = Platessa limanduides (Bl.)). Firth of Clyde (T. Scott). Irish Sea (A. Scott).

This species of Chondracunthus has not been observed on any other kind of fish. It was also from long rough dabs that Kröyer obtained his specimens of this parasite.

\section{Chondracanthus depressus T. Scott.}

\section{(Plate XLI, figs. 2-4; Plate LVI, figs. 1-7.)}

1905. Chondracanthus depressus T. Scott. (116) p. 114, pl. vi, figs. 7-13.

Female.-Head subquadrangular, nearly as long as broad. The first and second thoracic segments subequal, very short, and somewhat narrower than the cephalic segment, and that segment combined with the thorax not more than about a third of the entire length of the animal, the other two-thirds comprising 
the genital segment. This segment fully one and a half times as wide as the cephalon and its length only about a fourth greater than the width, a distinct transverse constriction dividing the segment into two nearly equal parts which are considerably flattened; the postero-lateral prolongations moderately short and stout, and blunt at the apex, also distinctly convergent so that the apices are usually contiguous, and sometimes overlap each other. Abdomen very short.

Antennules short and tolerably robust; simple in structure; the distal extremity, which appears to be obscurely jointed, bearing scattered apical spinules. Antennæ somewhat similar to those of Chondracanthus cornutus; the mandibles and maxillipeds also resembling those of the same species. Thoracic legs short, stout, biramose, both rami rudimentary, their surface covered with numerous very minute prickles. Length about $5 \mathrm{~mm}$.

Egg-strings short and stout and containing numerous ova.

This species has a general resemblance to Chondracantlus fluræ from the long rough dab, but is rather more flattened.

No males have been observed.

Habitat.-Parasitic on the gills of the flounder (Pleuronectes flesus). Firth of Forth and St. Andrews Bay (T. Scott). Irish Sea (A. Scott).

'This Chondracanthus differs from the other described species by the very short thoracic segment, by the genital segment being considerably flattened and of a broadly quadriform outline, and by the structure of the thoracic legs.

An apparent variety of the species here described, which has been observed parasitic on the same kind of fish, differs in being more elongated and rather less flattened; the thoracic legs are larger and more rudimentary, and the postero-lateral prolongations of the genital segment are scarcely convergent. This form, which has been recorded as variety oblongus, appears to be rare (see Pl. XLI, fig. 4; and Pl. LVI, figs. 5-7). 


\section{Chondracanthus limandæ Kröyer.}

(Plate XLVII, fig. 6; Plate LVI, figs. 11, 12.)

1863. Chondracanthus limand:e Kröyer. (71) p. 248, pl. xiv, fig. 2, $a-b$ 1900. Chondracanthus limandæ T. Scott. (112) p. 167, pl. vii, figs. 38-40.

Female.-Body tolerably robust; head large, length equal to about two-thirds of the width; first thoracic segment very short, considerably narrower than the head, second much larger, nearly as wide as the genital segment, and having on each side on the dorsal aspect a slightly-elevated rounded knob the diameter of which is equal to a third of the width of the segment.* Genital segment broad, not greatly elongated, and divided by a distinct transverse constriction into two nearly equal portions; the postero-lateral corners of the distal portion are produced into moderately short stout lobes with bluntly-rounded ends. Abdomen short, biarticulate, and nearly filling the space between the lateral lobes.

Antennules well developed, basal joint large, end one small but fairly well defined, and bearing a few small apical spines. Mandibles tolerably large; other mouth-appendages as in Chondracanthus cornutus. Thoracic legs stout but not greatly elongated. Length about $5 \mathrm{~mm}$. Length of egg-strings about the same. Colour opaque-white tinged with red.

Male.-The male of this species does not differ greatly in size or structure from that of Chondracanthus cornutus. The cephalothorax is greatly enlarged, but the abdomen is small and composed of about three segments. Antennæ and maxillipeds provided with stout terminal claws fitted for grasping. Length about $0.65 \mathrm{~mm}$.

Habitat.-Parasitic on the gills of the dab (Pleuronectes limanda Linn.). This parasite does not appear to be very common, and has only been met with on the dab. Kröyer obtained his specimens also on the

* Kröyer says,- "Annulo secundo duobus tuberculis humeralibus prædito magnis." 'Bidrag til Kundskab om Snyltekrebsene,' p. 256 (1863). 
same kind of fish. Firth of Clyde and Moray Firth (T. Scott). Irish Sea (A. Scott).

\section{Chondracanthus clavatus Bassett-Smith.}

(Plate XLVII, fig. 7 ; Plate LVI, figs. 14, 1う.)

1896. Chondrocanthus clavatus Bassett-Smith. (6) Ann. and Mag. Nat. Hist. (6), vol. 18, p. 13, pl. v, fig. 6.

1900. Chondracanthus clavatus T. Scott. (112) p. 165, pl. vii, figs. 35-37.

1901. Chondracanthus clavatus A. Scott. (107) p. 351.

Female.-Body claviform, somewhat flattened, anterior end narrow, expanded posteriorly. Head oval or subcylindrical, rather longer than broad; a median dorsal line, quite distinct in some specimens, extending backwards for some distance from the front margin. Thorax about as long as the head, but rather narrower and not very clearly defined; the head and thorax together equal to about two-fifths of the entire length of the animal. Genital segment clavate, somewhat flattened, and gradually becoming broader towards the posterior end; postero-lateral prolongations narrow and tolerably elongated, about equal in length to half the width of the segment, and having a comparatively wide space between them. Abdomen very small, indistinctly biarticulate.

Antennules short, moderately stout, end joint not clearly defined, provided with a few minute apical spines. Mandibles and other mouth - appendages somewhat similar to those of Chondracanthus cornutus. Thoracic legs small and rudimentary. Egg-strings moderately elongated. Length $6.5 \mathrm{~mm}$.

Male.-Very small; the cephalothorax is proportionally greatly enlarged, and the abdomen short and segmented. The antennæ are armed with short, stout, terminal hooks, and the maxillipeds are also similarly armed.

Habitat.-Parasitic on the gills of lemon-soles (Pleuronectes microcephalus). Plymouth (BassettSmith). Firths of Forth and Clyde (T. Scott). Irish Sea $(A . S c o t t)$. 


\section{Chondracanthus nodosus (O. F. Müller).}

(Plate LII, figs. 1-3 ; Plate XLVIII, figs. 13-16.) 1777. Lernxa nodosa O. F. Müller. (85) p. 40, pl. xxxiii, fig. 5 .

1816. Lernæa nodosa Lamarck. (72) p. 231.

1822. Lernentoma nodosa Blainville. (24) p. 125.

1838. Chondracanthus nodosus Kröyer. (70) p. 133, pl. iii, fig. 2.

1840. Chondracanthus nodosus M. Edwards. (43) p. 503.

1863. Chondracanthus nodosus Kröyer: (71) p. 258.

1909. Chondracanthus villiamsoni T. Scott. (118) p. 76, pl. iii, figs. 8-17.

Female.-Body flattened, and of an ovate form when seen from above; cephalon subquadrangular but with a shallow rounded projection on each side. A slight constriction separating the cephalon from the thorax. The genital segment, which is coalescent with the thorax, broadly ovate and flattened, and having the lateral margins coarsely crenulated or lobate, with six rounded but somewhat irregular projections on each side, the second and the last three being more prominent than the others; the posterior end terminating in a narrow median lobe. Abdomen much reduced in size, and of a rounded form.

Antennules small, uniarticulate, and rather rudimentary in structure. Antennæ short and armed with strongly-hooked terminal claws. Mandibles similar to those of Chondracanthus cornutus; both pairs of maxillipeds small; the first pair very similar to those of the species named, being composed of a stout basal part and a straight spine-like claw finely serrated on the inner edge; the second pair more elongated and narrow, and each armed with a short, stout, terminal claw and a small rounded process. Both pairs of thoracic legs rudimentary and nearly similar in structure; each limb consisting of a short and broad basal part, gibbous on both sides, which bears a small oblong distal process separated from the basal part by a narrow constriction. Egg-strings tolerably elongate and stout, and containing many ova. Length about $7 \cdot 5 \mathrm{~mm}$. Colour opaque white with a tinge of red.

Plate LII, fig. 2, represents a young female 
which, though resembling the adult in having the lateral margins coarsely crenulated, differs in being proportionally narrower and in the more quadrangular form of the cephalon.

Male.-The male is very small, the length being rather more than half a millimetre. The cephalothorax is considerably enlarged, and the abdomen short and indistinctly segmented. In size and structure the male closely resembles the male of Chondracanthus cornutus except that the structure of the thoracic part is slightly different.

Habitat.-Parasitic on Sebastes norvegicus; usually found fixed in the angles formed by the junction of the gill-covers with the gill-arches. On specimens of Sebastes captured in the North Sea and landed at the Fish-Market, Aberdeen, in February 1908 ('T. Scott).

\section{Chondracanthus zei De la Roche. \\ (Plate XLI, fig. ǒ ; Plate LVI, fig. 13.)}

1811. Chondracanthus zei De la Roche. (41) p. 270, pl. ii, fig. 2. 13.

1822. Chiondracanthus delarochiana Blainv. (24) p. 422, pl. xxvi, fig.

1829-1843. Chondracanthus zei Guérin-Méneville. (55) t. 9, fig. 9.

1831. Chondracanthus zei Burmeister. (26) p. 325.

1832. Chondracanthus tuberculatus Nordmann. (89) p. 118.

1850. Chondracanthus zei Baird. (4) p. 327 , pl. xxxv, fig. 1.

1851. Chondracanthus zei P. J. van Beneden. (11) p. 110, pl. iv, figs. 5-7.

1892. Chondracanthus zei T. Scott. 10th Ann. Report Fishery Board for Scotland, pt. iii, p. 262.

1896. Chondracanthus zei Bassett-Smith. (7) p. 162.

1900. Chondracanthus zeus T. Scott. (112) p. 167, pl. viii, fig. 1.

1906. Chondracanthus zei Norman \& T. Scott. (88) p. 217.

Female.-Body short, moderately stout, and of a somewhat ovate form. Head small, orbicular; thorax very short, narrowed behind the head where it forms a kind of neck. The genital segment, with which the thorax appears to be more or less coalescent, flattened and becoming gradually and considerably wider posteriorly. Abdomen small and rudimentary. A short horn-like process extends outwards from both sides of the thoracic segment and there is a trifid process on 
its dorsal aspect. Genital segment furnished with two pairs of tridigitate appendages on the under side and with three pairs of somewhat similar digitiform prolongations on the lateral aspect, the posterior prolongations being the larger; these latter appendages surround and nearly conceal the short, stout, and flattened ovisacs; several median processes also occur on the dorsal aspect of the genital segment.

Antennules short and moderately expanded. Antennæ prehensile and provided with stout terminal hooks. Mandibles and other mouth-appendages

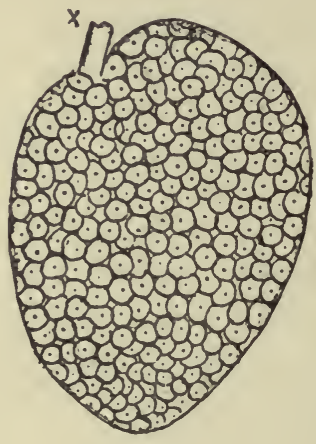

$a$

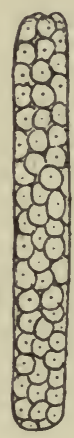

$b$

One of the ovisacs of Chondracanthus zei.

similar to those of Chondracanthus cormutus. Thoracic legs indistinctly biramose, and their structure somewhat rudimentary. Ovisacs, which are short and contain numerous small ova, compressed laterally. so as to have a broadly and somewhat obliquely ovate outline; not extending beyond the ends of the prolongations described above. Colour white tinged with red. Length about $12 \mathrm{~mm}$., but the size somewhat variable.

Male.-The male of this species does not appear to differ greatly from that of Chondracanthus cormutus in size and structure.

Habitat.-Parasitic on the gills and gill-arches of the dory (Zeus faber). Polperro, Cornwall (A. M. Norman). Plymouth (Bassett-Smith). Firths of Forth 
and Clyde (T. Scott). Irish Sea (A. Scott). This parasite is of frequent occurrence on the dory, and Dr. Bassett-Smith describes it as very common on the gills of Zeus faber at Plymouth.

The ovisacs of Chondracanthus zei differ so remarkably from those common to most of the species known to us that we give here a figure showing a side and an end view, enlarged, of one of them. When the parasite is viewed from the ventral aspect the ovisacs appear as in figure $b$, but the side view $a$ can best be seen whem the ovisacs are removed. $\mathrm{x}$ shows the point of attachment of the ovisac to the genital segment.

\section{Chondracanthus lophii Johnston. \\ (Plate LII, fig. 4; Plate LVI, figs. 16-18.)}

1836. Chondracanthus lophii Johnston. (67) p. 81, fig. 16.

1837-1838. Chondracanthus gibbosus Kröyer. (70) (1) p. 252, pl. ii, fig. 4 .

1843. Chondracanthus lophii Rathke. (100) p. 116, pl. v, figs. 16-18.

1847. Chondracanthus gibbosus Thompson. (129) p. 248.

1850. Lernentoma lophii Baird. (4) p. 330, pl. xxxv, fig. 3.

1851. Chondracanthus gibbosus P.J.van Beneden. (11) p. 104, pl. iii, figs. 10-15.

1862. Chondracanthus lophii Turner \& Wilson. (140) p. 67, pl. iii.

1877. Chondracanthus gibbosus Vogt. (142) p. 76, pl. v, figs. 1-4; pl. vi, figs. 1-3.

1896. Chondracanthus lophii Bassett-Smith. (7) p. 162.

1900. Chondracanthus lophii T. Scott. (112) p. 167.

Female.-Body tolerably elongated, narrow in front, posterior end moderately broad and flattened. Head small, having on each side a horn-shaped appendage directed obliquely backwards. Thorax narrow and furnished with one or two short, paired, marginal processes directed outwards, and a pair of bifurcated moderately long ventral appendages. Genital segment flattened, and about twice as long as broad, constricted in the middle so as to form two subequal portions, the postero-lateral corners of both of which form short prolongations; this segment also furnished with a row of median digitiform processes alternately larger and smaller, and directed obliquely backwards. Abdomen very short. Egg-strings greatly elongated and more or less twisted into loops. 
Antennules short, conspicuous in front, their basal part considerably expanded, but the distal end narrow, and minutely setiferous. Antennæ short and stout, and armed with strong terminal hook-like claws. Mandibles and other mouth-organs somewhat similar to those of Chondracanthus cornutus. Thoracic legs indistinctly biramose, and more or less rudimentary in structure. Length about $12 \mathrm{~mm}$.

Male.-The male of this species, like that of the last, has a close resemblance to the male of Chondrocanthus cornutus as indicated by Dr. Baird. It is of a pyriform shape, considerably swollen in front but tapering towards the distal end, and furnished with strongly uncinate foot-jaws. It is usually found clinging to the female, but from its minute size may easily be missed.

Habitat.-Parasitic usually on inner surface of the gill-pouches of angler-fishes (Lophius piscatorius Linn.). It is a moderately common species on the angler-fish and has been recorded from various parts of the British coast. Dublin, 1839 ; Belfast, $18+1$ (IIT. Thompson). Coasts of Devon and Cornwall (C. Parlier, A. M. Norman, and others). Irish Sea, and various parts of the Scottish coasts (I'. $\& A$. Scott). For a detailed account of the anatomical structure of this curious species see Turner and Wilson's memoir referred to above. The colour of this Chondracanthus is usually opaque white. 'The egg-string's are of great length, usually in screw-form, very slender, and contain numerous small ova. Specimens may often be found in considerable numbers in the gill-pouches of both large and small anglers.

\section{Chondracanthus merluccii (Holten).}

(Plate XX, fig. 10; Plate XLVII, fig. 8; Plate LIII, figs. 16-19.)

1802. Lernæa merluccii Holten. (63) vol. v, pl. iii. fig. 2.

1837. Chondracanthus merluccii Kröyer. (70) p. 278 , pl. iii, fig. 9.

1840. Chondracanthus merluccii M. Edwards. (43) rol. iii, p. 503. 
1892. Chondracanthus merluccii T. Scott. 10th Ann. Rept. Fishery Board for Scotland, p. 262.

1896. Chondracanthus merluccii Bassett-Smith. (7) p. 161.

1900. Chondracanthus merluccii T. Scott. (112) p. 166.

1906. Chondracanthus merlucii Brian. (21) p. 97, pl. vii, fig. 4 .

1906. Chondracanthus merluccii Norman \& T. Scott. (88) p. 217.

F'emale.-Body oblong and flattened. Head somewhat wedge-shaped, wider behind than in front, the front margin rounded, and a more or less distinct median line extending from it backwards; the head seen in profile sloping upward and backward, and becoming distinctly gibbous behind; provided witl small, lateral horns-one on each side near the posterolateral corners-which extend obliquely backwards like the barbs on a fishing hook. Thorax short, indistinctly bisegmented; a constriction separating the head from the thorax and another separating the thorax from the genital segment; the second segment of the thorax wider than the first and nearly as wide as the genital segment; its anterior lateral corners produced forwards into small round knobs. Genital segment moderately thick, and flattened dorsally, a slight constriction dividing it into two nearly equal portions; a pair of tolerably stout and elongated processes springing from the ventral aspect of the segment just in front of the constriction, and extending obliquely backwards so as to reach beyond its posterior end; the postero-lateral corners of the genital segment also produced backward into elongated and moderately stout horn-like prolongations. Abdomen very small.

The two pairs of antennæ and the mouth-appendages similar to those of Chondracanthus cornutus; so are also the thoracic legs, except that the second pair are considerably larger than the first. Length to the end of the posterior processes about $12 \mathrm{~mm}$. These processes about three millimetres in length, being rather shorter than the ventral prolongations, which measure about four millimetres. Egg-strings about ten millimetres in length, moderately thick, and containing numerous ova. 
Male.-The male of this species is very small, being scarcely more than half a millimetre in length; the cephalothorax, as in the male of Chondracanthus cornutus, is proportionally large ; the abdomen is small and composed of two or three segments. Sometimes more than one male may be found adhering to a female.

Habitat.-Parasitic on the hake (Merluccius vulgaris Cuv.). Usually found clinging to the roof and sides, sometimes on the under side of the tongue and on the inside of the gill-covers. Frequently the head is either buried in the tissues of the fish or enveloped in mucus. This is a tolerably common parasite of the hake, and a considerable number of specimens may sometimes be obtained from a single fish. Coasts of Devon and Cornwall (C. Parker, Laughrin, Bassett-Smith). Irish Sea (A. Scott). Firths of Forth and Clyde, Aberdeen, \&c. $(T . S \operatorname{scott})$.

\section{Chondracanthus ornatus 'T. Scott.}

\section{(Plate XLI, fig. 6; Plate XLV, fig. 7.)}

1900. Chondracanthus ornatus T. Scott. (112) p. 168 (description only).

1901. Chondracanthus ornatus idem. (113) p. 129, pl. vii, fig. 14 ( $q)$.

1902. Chondrucanthus ornatus idem. (114) p. 298, pl. xiii, fig. 34 (ठ).

Female.-When viewed from above with a general outline closely similar to that of an equilateral triangle, the bluntly-rounded head forming the apex, and the truncated posterior end the base; the front of the head indistinctly trilobed, one bluntly-rounded lobe being in the centre, and projecting slightly in front of the two lateral lobes which are also bluntly rounded. The neck connecting the head with the thorax very short. Three or four, more or less distinct, tubercles along each side of the thorax (forming the sides of the triangle), a series of three similar tubercles extending along the middle of the dorsum ; the posterior tubercle of the middle series standing well up, but each of the other two standing at a slightly lower elevation than the one immediately behind. The arrangement and 
position of these lateral tubercles seems to vary slightly in different specimens. Abdomen exceedingly small and inconspicuous. Egg-strings of moderate length and stoutness, like those of Chondracanthus limandx.

The size of the more typical of the female specimens observed is as follows:-from the forehead to the posterior end of the body $5 \mathrm{~mm}$., from the forehead to the end of the egg-strings $11.5 \mathrm{~mm}$., the width of the genito-thoracic segment at the posterior end about equal to the length, so that, as already stated, the body of the animal has a general outline closely similar to that of an equilateral triangle.

Male.-The male is very small, measuring scarcely half a millimetre in length; it is of a robust form and does not differ very much from the male of Chondracanthus cornutus.

Habitat.-Parasitic on the gills of spotted dragonets (Callionymus maculatus Bonap.). Firth of Clyde, 1899 and 1901 ; Moray Firth, 1900.

Though Chondracanthus ornatus is of a tolerably large size, it is so well concealed that it easily escapes notice, and it is only by turning back the gill-covers that the observer can be sure whether the parasite is present or not. Hitherto this Chondracanthus has only been obtained on the spotted dragonet, and frequently it has been found associated with another species-the Hærmobaphoides ambiguus (T. Scott), previously described. As pointed out in the description of Hæmobaphoides, the two species sometimes occurred on the same fish, on opposite sides or on the same side; occasionally also a Chondracanthus would be found on one side and a Hrmobaphoides on the other. The Chondracanthus was usually of a purplish colour tinged with brown. About 14 per cent. of the fishes examined were found to harbour the Chondracanthus.

\section{Genus 37. MEDESICASTE Kröyer, 1863.}

Syn. Chondracanthus Auct.; Lernentoma Baird; Oralien Bassett-Smith.

This genus was established for the reception of a Chondracanthus which, though agreeing in some 
respects with that genus, yet differed because of the remarkable arrangement of the cephalic appendages. In typical Chondracanthus these appendages are situated in more or less proximity to each other, but in Medesicaste the anterior portion of the cephalothorax, which has a bulb-like form, and is provided with two pairs of antennæ; is separated from the thorax and the thoracic appendages by a moderately long and narrow neck: by this arrangement a considerable distance intervenes between the two pairs of antennæ and the mouth and other thoracic organs. The posterior part of the body is tolerably large and robust, its lateral margins are deeply incised, dividing it into two portions: the thoracic, which carries on the ventral aspect two pairs of bilobed blunt-pointed processes and other appendages; and the genital, which is rounded and rather larger than the other, and has its postero-lateral corners produced into more or less angular lobes. Abdomen small, biarticulated, and more or less inclosed between the lateral lobes of the genital segment. Egg-string's elongated, claviform.

Male very small, similar to the male of Chondracanthus.

We are unable to find any valid difference between Medesicaste Kröyer and Oralien Bassett-Smith.

'The only British species of Medesicaste is that describerl below.

\section{Medesicaste asellinum (Linn.).}

(Plate LII, fig. 6; Plate LVII, figs. 18, 19.)

1761. Lernæa asellina Linn. Fauna Suec., 2101; Syst. Nat., Edit. 12. vol. i, pt. ii, p. 1093 (1767).

1829-1843. Chondracanthus trigla Guérin-Méneville. (55) Inconograph., pl. ix, fig. 8.

1822. Lernentoma triglæ Blainv. (24) p. 441, pl. lxii, fig. 12.

1832. Chondrocanthus triglie Nordmann. (89) p. 116 , pl. ix, figs. 1-4.

1838. Chondracanthus triglæ Kröyer. (70) p. 135 , pl. iii, fig. 3.

1850. Lementoma asellina Baird. (4) p. 329, pl. xxxv, fig. 4.

1863. Medesicaste triglarum Kröyer. (71) p. 312, pl. xviii, fig. 1, a-b

1869. Chondracanthus triglæ Steenstrup. (126a) pl. ii, fig. 3.

1896. Chondracanthus triglæ Bassett-Smith. (6) p. 13, pl. iv, fig. 4.

1899. Oralien asellinus idem. (8) p. 490. 
1900. Oralien asellinus T. Scott. (112) p. 163, pl. vii, figs. 16-18.

1906. Medesicaste triglarum Brian. (21) p. 94.

Female.-Head sinall, subglobose, situated at the end of a tolerably long and slender neck, rounded in front, and with each side expanded into rounded lobes, the whole forming a bulb-like extremity usually inclosed in the tissues of the host; this anterior part furnished with two pairs of antennæ, which are small and have hook-like extremities. The neck, where it joins the posterior portion of the body, slightly enlarged. This posterior portion of the body tolerably large and robust and divided by a deep transverse constriction into two subequal parts; the front part appearing to constitute the thorax with its appendages, and the lower the genital segment, the antero-lateral corners of which extend outwards into angular projections; the lateral margins of this lower segment slightly arcuate, converging distally, and forming two small postero-lateral lobes, separated from each other by a small median sinus, best seen from the ventral aspect. Abdomen very small, occupying the space between the postero-lateral lobes.

Both pairs of antennæ small, and situated on the subglobose cephalic segment as described above. Mandibles stont, falcate, and with their margins fringed with numerous small teeth as in Chondiacantluss; maxillæ and other mouth-appendages also somewhat similar to those in Chondracanthus. Thoracic legs two pairs, very rudimentary. Colour pale red. Ego-strings nearly as long as the body and containing many ova. Length exclusive of egg-strings about $7 \mathrm{~mm}$.

Male.-Extremely small and similar in structure to the male of Chondracanthus.

Habitat.-Parasitic on the gills of Trigla spp., Gadus spp.; also on the plaice (Pleuvonectes platessa) and other fishes, captured in British waters, frequent.

A somewhat variable species, and apparently widely distributed. 


\section{Family vir. LeRneOPODIDA:}

Female.-Body in the adult female usually nonsegmented or indistinctly or incompletely so. Head small, thorax not clearly defined, narrow and more or less elongated, but sometimes short as in Lernæopoda cluthæ. Abdomen usually separated from the thorax by a constriction tolerably distinct but seldom if ever forming a complete articulation; the genital segment of the abdomen usually enlarged and sometimes provided with posterior processes; the remaining abdominal segments usually obsolete or rudimentary. Appendages of the cephalon and thorax comprising antennules and antennæ, mandibles, maxillæ, and first and second maxillipeds, but the thoracic usually obsolete or entirely wanting. The second maxillipeds armlike appendages elongated or short, and modified to form organs of attachment, the arms entirely separated except at the tip or partly or completely coalescent; united at the distal extremity to a chitinous process which penetrates the tissues of the host, and the character of which may vary in the different species. Egg-strings generally only moderately elongated and the ova small and arranged in a multiseriate manner.

Male.-Very small and furnished with several appendages the structure of which is more or less rudimentary. Its form varies in the different genera, and it is usually found adhering to some part of the female-i.e., the rudimentary abdominal segment or the cephalothorax.

Milne Edwards included Anchorella (Clavella) in his Family Lernéopodiens, but Dr. Baird removed this genus and established the Family Anchorellidæ for its reception. 'I'he difference between Lernæopnda and Anchorella is obvious in two particulars-in the structure and modification of the second maxillipeds and in the form of the pygmy male. 'The first provided Baird with the principal character by which the two Families could be distinguished, and might have been considered valid except for the occurrence of genera intermediate in structure, which made it more convenient to include them all under the one Family Lernæopodidæ. 
Genus 38. THYSANOTE Kröyer, 1863.

Syn. Brachiella Nordmann (in part).

Cephalothorax short, robust; genital segment short, dilated, and somewhat flattened, the postero-lateral corners each provided with two moderately short processes of about equal length; another pair of rather longer submedian appendages springing from the ventral aspect and a little in front of the posterior margin. Abdomen obsolete or nearly so.

Both pairs of antennæ small and rudimentary. Mandibles moderately elongated, and having the inner margin near the distal end coarsely and irregularly serrate. Maxillæ and first maxillipeds somewhat similar to those of Brachiella. Second maxillipeds free, each with the extremity expanded and obscurely trilobed, the tip of the inner lobe of each maxilliped being apparently united together.

Thysanote has a close general resemblance to Brachiella, both in the form of the body and in the free second maxillipeds; the structure however of these maxillipeds differs, and the genital segment also differs in being furnished with two pairs of posterior appendages.

\section{Thysanote impudica (Nordmann).}

(Plate XXXIII, fig. 5; Plate XLIX, figs. 8-11.)

1832. Brachiella impudica Nordmann. (89) vol. ii, p. 92, pl. viii, fig. 1. 1840. Brachiella impudica M. Edwards. (43) p. 513.

1877. Brachiella impudica Vogt. (142) vol. xvi, p. 436.

1899. Thysanote impudica Bassett-Smith. (8) p. 162.

1900. Thysanote impudica T. Scott. (112) p. 169, pl. viii, figs. 2-5.

Female.-Cephalothorax short, robust, strongly arcuate, and about as long as the genital segment. Genital segment short, about as broad as long, flattened and subquadriform, posterior truncated and furnished with three pairs of short appendages, one pair on each side and one pair submedian.

Both pairs of antenne somewhat rudimentary. Mandibles moderately stout at the distal end, and having the inner margin coarsely and irregularly serrate, 
some of the teeth being alternately larger and smaller. Maxillæ moderately stout, furnished with two moderately long, narrow, and spiniferous apical processes, two small spinules also springing from a subapical rudimentary lobe. The first maxillipeds very short, stout, and strongly uncinate. The second maxillipeds very short, with the distal end expanded and united at the top. Length from the forehead to the end of the longer posterior appendages about $6.5 \mathrm{~mm}$.

Male.-We have not ourselves seen the male of Thysanote impudica; Nordmann gives a figure of it and describes it as very minute (about $0.6 \mathrm{~mm}$.). It somewhat resembles the male of Brachiella, and its appendages also appear to be somewhat similar to those of that genus.

Habitat.-Parasitic on the gills of Trigla sp. and Gadus sp. On the gills of sapphirine gurnard (Trigla hivundo) captured at Polperro and Starcross (A. M. Norman). Plymouth (Bussett-Smith). Irish Sea (A. Scott). Moray Firth (T. Scott). Dr. Bassett-Smith records this species also from Trigla cuculus and gurnardus; and M. Nordmann from Gadu.s rglefinus (the haddock).

\section{Genus 39. CHAROPINUS Krö!̣er, 1863.}

Syn. Lernæa Retzius (in part); Lerneopoda Nordmann (in part).

Female.-Cephalothorax of moderate size, ovate or sub-conical, indistinctly segmented, with obscure transverse constrictions behind the cephalon; neck short or none. Genital segment pyriform or elongateovate; abdomen very small or obsolete. Posterior appendages two, slender, short, one on each side of the abdomen. Antennæ short, stout, uncinate. Mandibles and first maxillipeds nearly as in Thyssanote. Second maxillipeds greatly elongated, slender, or moderately stout, contiguous or coalescent at the apex. Apex enlarged or biramose, and clasping a cross bar of chiton, or greatly attenuated and fixed at 
the tip to a large horizontal chitinic appendage. Eggstrings tolerably thick and elongate, and containing numerous ova.

Male.-Very small, somewhat similar in structure to the male of Levnsopoda cluthx.

\section{Charopinus dalmanni (Retzius).}

\section{(Plate LV, figs. 1-4; Plate LIV, figs. 12-17.)}

1829. Lernæa dalmanni Retzius. (101a) p. 109, vol. xxix, p. 6, figs. 5-9, (1830).

1832. Lerneopoda dalmani Nordmann. (89) p. 138.

1837. Lernæopoda dalmanni Kröyer. (70) vol. i, p. 264.

1862. Lerneopoda dalmanni Turner \& Wilson. (140) p. 77, pl. iv.

1863. Charopinus dalmanni Kröyer. (71) p. 280, pl. xiv, figs. 6, $a-g$.

1879. Stylophorus hypocephalus Hesse. (59) (6) vol. viii, art. 15, p. 31.

1891. Charopinus dalmanni T. Scott. 9th Ann. Report Fishery Board for Scotland, p. 310.

1900. Charopinus dalmanni idem. (112) p. 169, pl. viii, figs. 6-10.

1904. Charopinus dalmanni A. Scott. (109) p. 43.

Female.-Cephalothorax short, somewhat triangular in outline, and usually bent abruptly downwards so as to form a more or less distinct angle with the posterior part of the body. There springs from each side of the angle thus formed a long, moderately slender, and indistinctly annulated appendage which at the apex becomes dilated and lunuliform. The lunuliform apices of these elongated appendages, otherwise described as the second maxillipeds, though not actually coalescent, fit closely together, and clasp a cartilaginous or chitinous bar which extends some distance on each side of the conjoined apices; this complex structure, buried in the tissues of the fish, forms a secure anchorage for the parasite. Immediately in front of the base of each of the second maxillipeds there is on each side of the thorax a small rounded protuberance termed by Retzius and Kröyer "eye-like spots," but they are not supposed to be eyes, and their true character seems to be obscure. The posterior and genital portion of the body becomes gradually and considerably enlarged toward the distal end, and the postero-lateral corners form bluntly- 
rounded knobs. Two moderately long and slender appendages spring from the ventral aspect just in front of the base of the egg-strings and extend backwards some distance beyond the end of the genital segment. Abdomen and caudal rami obsolete. Antennules stout, short, and apparently three-jointed; antennæ short with a gibbous basal part, and the small end joint provided with a minute terminal claw. Mandibles slender, moderately elongated, and with a portion of the inner margin of the end joint coarsely serrate; maxillæ simple and furnished with a few apical setæ. No thoracic legs observed. Length from the apex of the second maxillipeds to the end of the posterior appendages about $47 \mathrm{~mm}$. Colour opaque white tinged with red.

Male.-Very small, scarcely reaching beyond two millimetres in length. Somewhat like Levnxopoda cluthæ in general appearance but larger. T'horax and abdomen segmented. Maxillipeds short and stout and furnished with strong terminal claws.

Habitat.-Parasitic in the nasal fossæ or spiracles of gray (or blue) skates (Raia batis). Firth of Forth; frequent on large Raia batis brought to the FishMarket at Aberdeen (T. Scott). Firth of Forth, 1862 (Dr. Wilson). Polperro, Cornwall (A. Mr. Norman). Irish Sea (A. Scott). Usually only one specimen is present in a spiracle, but two and sometimes three have been observed almost blocking up the spiracle.

\section{Charopinus dubius 'T. Scott.}

(Plate LV, fig. 5.)

1900. Charopinus dubius T. Scott. (112) p. 130, pl. vii, fig. 15.

Female.-Somewhat resembling Charopinus dalmanni Retzius in general appearance and also in some of its appendages, but considerably smaller, being little more than half the size.

The principal structural characters by wnich it is distinguished from that species are those of the 
complex form of the anchoring arrangement of the second maxillipeds, which are more slender in proportion to their length; their apices appear to be coalescent, and are fixed to a moderately large horizontal appendage which is cartilaginous and of a brownish colour. This appendage, when perfect, is somewhat boat-shaped with the extremities slightly turned up ; it has a resemblance to the cartilaginous bar clasped by the enlarged apices of the second maxillipeds of Charopinus dalmanni, but there the resemblance ends, for in that species the ends of the second maxillipeds when freed from the cartilaginous bar separate freely, whereas in the species under consideration they remain fixed together by a small hardened plug as in Lernæopod", and do not separate freely. The two pairs of antennæ, the mandibles, and other mouth-organs do not appear to differ greatly from those of Charopinus dalmanni. The ventral appendages at the posterior end of the genital segment are also similar. Length of one of the larger specimens : maxillipeds $11 \mathrm{~mm}$., cephalothorax $6 \mathrm{~mm}$., genital segment $8.5 \mathrm{~mm}$., posterior appendages $4 \mathrm{~mm}$., egg-strings $18 \mathrm{~mm}$., and from the chitinic bar to which the maxillipeds are fixed to the end of the posterior appendages, $26 \mathrm{~mm}$.

No males of this species have been observed.

Habitat.-Parasitic on the gills and gill-arches of the cuckoo ray (Raia circularis) chiefly, and less frequently on other skates, Firth of Clyde and Fish-Market, Aberdeen (T. Scott). On Raia fillonica captured off Dubh Artach (A. Scott).

\section{Charopinus ramosus Kröyer.}

(Plate LV, figs. 6, 7 ; Plate LIV, figs. 18-22.)

1863. Charopinus ramosus Kröyer. (71) p. 284, pl. xiv, fig. 5, $a-i$.

1901. Charopinus ramosus T. Scott. (113) p. 130, pl. vii, figs. 17-23.

1904. Charopinus ramosus A. Scott. (109) p. 43.

Female.-In this species the cephalothorax is not deflexed in front of the bases of the second maxillipeds, but is projected forward as in Lemropoda galei. 
It has also an ovate or pyriform outline, narrow in front. Genital segment elongated, narrow, and only slightly enlarged towards the posterior end.

Antennules short and composed of two joints, a stout basal joint and a narrow end one which is furnished with a few apical spines, a small bristle also springing from near the end of the basal joint. Antennæ, like those of Charopinus dubius, short and stout, the outer ramus consisting of a small joint articulated to the inner ramus and provided with two short unequal spines; the inner ramus stout with a gibbous rounded end, both rami covered with microscopic prickles. Mandibles narrow, oblong, the apex obliquely truncate and coarsely serrated; maxillæe small, moderately stout, biarticulate, and furnished with three apical and subapical spines and a small setiferous process. First maxillipeds three-jointed; second joint with a small setiferous knob near the proximal end of the inner margin; end joint slender, and armed at the apex with two minute spines and a small slightly-curved claw. Second maxillipeds slender and about as long as the body, exclusive of the posterior appendages, becoming considerably altered at the distal end where their inner surfaces are closely adherent, and extending on each side into biramose processes which penetrate the tissues of the host and form a secure anchorage for the parasite. The genital segment furnished with two posterior appendages moderately short and slightly divaricate.

Male.-We have not ourselves noticed the male of this species, but Kröyer describes and figures it in the work quoted above.* It is, though smaller, very like the male of Charopinus dalmanni, and is characterized by a similar stout proboscis in front of the head and by powerful maxillipeds fitted for grasping.

Habitat.-Parasitic on the gills and gill-arches of Raia clavata and Raia maculata. Fish-Market, Aber-

* "Bidrag til Kundskab om Synltekrebsene," 'Natur. Tidssk.,' 3 Raekke, 2 Bind, p. 287. 
deen $(T . S c o t t)$. Irish Sea $(A . S \operatorname{sot} t)$. This appears to be a moderately rare species in British waters.

\section{Genus 40. ACHTHERES Nordmann, 1832.}

Female-Cephalothorax short and broadly ovate, separated from the genital segment by a tolerably distinct constriction. Genital segment oval or subglobose, and sometimes exhibiting a more or less segmented structure. The two pairs of antennæ and the mouthappendages not differing much from those of Lernæopoda; second maxillipeds short, stout, free, but united at the tip to a circular chitinous disk, which is expanded in front. Genital segment usually furnished with two small processes at the distal extremity. Egg-strings short, dilated or saccate; ova tolerably large.

Male.-Very small; first maxillipeds short, very robust, strongly uncinate; second maxillipeds elongated, stout; terminal claws small.

Parasitic for the most part on freshwater fishes.

\section{Achtheres percarum Nordmann.}

(Plate L, figs. 6-8; Plate LIX, figs. 7, 8; Plate LXIV,

$$
\text { figs. 1-3.) }
$$

1832. Achtheres percarum Nordmann. (89) p. 63 , pl. iv.

1838. Achtheres percarum Kröyer. (70) ii, p. 143, pl. iii, fig. 6 .

1840. Achtheres percarum M. Edwards. (43) p. 511, pl. xl, fig. 8.

1861. Achtheres percarum Claus. (32) p. 287, pls. 23, 24.

1899. Actheres percarum Bassett-Smith. (8) p. 498.

1901. Actheres percarum T. Scott. (113) p. 132.

1904. Achteres percarum Pehr Gadd. (47) p. 21.

1906. Achtheres percarum Brian. (21) p. 101.

Female.-Cephalothorax of moderate size, narrower in front than behind. Genital segment sub-globose, rather longer than broad, separated from the cephalothorax by a distinct constriction; the posterior end of the segment slightly angular, bearing two minute processes - one on each side of the median line. Abdomen obsolete. Egg-strings short, stout, saccate, scarcely equal in length to the genital segment. Ova large. 
Antennæ and mouth-appendages somewhat similar to those of Lernæopoda salmonea. The second maxillipeds nearly as long as the genital segment, free except at the tips where they are united to a small obconical chitinous plug.

We have not seen the male of Achtheres percarum, but it has been described by Nordmann. It is very small, measuring little more than a millimetre in length.

Habitat.-Parasitic on the gills of fresh-water perch and trout. On the gills of the common trout, Moray Firth district (T. Eduard, in 'Museum Normanianum'). On the gills of a trout captured by Mr. W. S. Caine in Loch Awe, a small fresh-water loch in Assynt, Sutherlandshire ('I'. Scott).* On the gills of a trout captured in Loch Tay, Perthshire, by Dr. Williamson, to whom we are indebted for the specimen.

The specimens recorded above agree generally with the form described and figured by Nordmann, except that the genital segment is not seginented as his drawing shows it to be (this drawing is reproduced on Pl. L, fig. 6, for coinparison with Scottish specimens).

The chitinous plug by which the female Achtheres is fixed to its host is considerably and regularly expanded in front, as shown by fig. 7, Pl. LIX. This form of plug appears to be characteristic of the genus, and differs entirely from that of the closely allied Lernxopoda salmonea, which is of a broadly lingulate form.

Dr. Pehr Gadd, in his account of the Copepod parasites found on the fishes of Finland, describes a species parasitic on the fresh-water fish Lusioperca sandra, under the name of Achtheres sandræ. $\dagger$ In that species the genital segment is not segmented, resembling, in that respect, the specimens described above.

* "The Invertebrate Fauna of the Inland Waters of Scotland," "Twelfth Annual Keport of the Fishery Board for Scotland,' Part III, p. 287 (1894).

+ "Parasit-Copepoder I Finland," "Acta Societatis pro fauna et flora Fennica,' vol. xxvi, No. 8, p. 22, pl. i, fig. 1 (1904). 
Genus 41. LERNÆOPODA Blainville, 1822.

Female.-Body generally elongated; cephalothorax short, wider behind than in front, more or less distinctly separated from the remaining part of the body, and sometimes with a chitinous shield-like dorsum. Genital segment elongated, sometimes ovoid or saccate, and unsegmented. Abdomen obsolete or nearly so; posterior processes two, short, or none. First maxillipeds near and a little behind the mouth. Second maxillipeds long or moderately short, slender, wide apart, and only united at the tip to a chitinous button or plug usually buried in the tissues of the host.

Male.-Much smaller than the female, somewhat elongated and distinctly segmented. Cephalothorax. sometimes provided with a dorsal shield, and usually separated from the abdomen by an obvious articulation. Abdomen usually segmented. Antennules small, twoor three-jointed. Antennæ tolerably large. Mouth in the form of a short conical siphon. Maxillipeds large and uncinate.

\section{Lernæopoda elongata (Grant).}

\section{(Plate LXI, figs. 5, 6; Plate LVII, figs. 13-17.)}

1827. Lernæa elongata Grant. (53) vol. vii, p. 147, pl. ii, fig. 5 .

1838. Lernæopoda elongata Kröyer. (70) i, pl. 2, fig. 12; pl. 3, fig. 3 a. 1840. Lernæopoda elongata M. Edwards. (43) p. 515.

1850. Lerneopoda elongata Baird. (4) p. 333, pl. xxxv, fig. 5 .

1861. Lernxopoda elongata Stp. \& Ltk. (127) p. 422, pl. xv, fig. 37.

1861. Lernxopoda elongata P.J. van Beneden. (15) p. 154.

1862. Lerneopoda elongata Turner \& Wilson. (140) p. 85.

1900. Lernxopoda elongata T. Scott. (112) p. 171, pl. viii, figs. 11-15.

Female.-Cephalothorax distinct, ovate, flattened, obtusely and narrowly rounded in front, but becoming gradually wider and thicker behind, the posterior margin being rounded and somewhat gibbous. Genital segment elongate, subcylindrical, slightly depressed, about as wide as the cephalothorax but distinctly narrower where it joins the head; distal end truncated and provided with two small appendages on the ventral 
aspect-one on either side of the median line and in front of the origin of the egg-strings. Abdomen very minute, the genital segment showing no trace of segmentation.

Antennules short, basal joint stout, the others narrower. Antennæ very short, stout, and bluntly orunded at the end, furnished with a minute branch near the distal end (Pl. LVII, fig. 14). Mandibles small, elongate, narrow, and having the inner margin near the distal end distinctly serrated. First maxillipeds short, stout, armed with moderately strong terminal claws. Second maxillipeds long and slender, exceeding the length of the body; they "taper abruptly at their distal ends and are connected to a small, rounded, horny, or chitinous disk."* The extremities of the arms, where they join, closely contiguous but not coalescent with each other. Length from posterior end of the genital segment to the tips of the second maxillipeds about $40 \mathrm{~mm}$., the maxillipeds alone measuring over $20 \mathrm{~mm}$.

Male.-We have not seen the male of this species, but Steenstrup and Lütken (op.cit., p. 423) give the size as about $1 \mathrm{~mm}$., and their figure shows that the cephalothorax, which is provided with large uncinate maxillipeds, is separated from the abdomen by a not very strongly defined segment; the abdomen is more dilated than the cephalothorax and is also unsegmented.

Habitat.-Parasitic usually on the eyes of the Greenland shark (Lamna cornubica). Obtained on a Greenland shark caught on the English coast in the winter of 1848 by Mr. Yarrell, who gave the specimen to Dr. Baird ('Entom.,' p. 334). Taken on the smooth hound (Mustelus vulgaris) at Polperro (A. M. Norman). A specimen was obtained by Mr. H. Dannevig on the eye of a shark captured east of Fair Isle between Orkney and Shetland in October 1900. Another was obtained by Mr. Ingram, Fishery Officer, on a Green-

* Turner and Wilson, "Observations on the Parasitic Crustacea, Chondracanthus Lophii and Lerneopoda dalmanni," "Trans. Roy. Soc. Edinb.' vol. xxiii, Pt. 1, p. 85 (1862). 
land shark captured in the North Sea and landed at Aberdeen Fish-Market in April 1901. Both specimens were examined by us.

\section{Lernæopoda galei Kröyer.}

(Plate LX, figs. 4-6 ; Plate LVIII, figs. 9-15; Plate LXIII, fig. 1.)

1837. Lernæopoda galei Kröyer. (70) p. 272, pl. iii, fig. 5 .

1840. Lernæopoda galei M. Edwards. (43) p. 516.

1850. Lemeopoda galei Baird. (4) p. 334, pl. xxxv, fig. 7.

1851. Lernæopoda galei P. J. van Beneden. (11) p. 120, pl. iv.

1896. Lernæopoda galei Bassett-Smith. (7) p. 163.

1900. Lernæopoda galei T. Scott. (112) p. 172, pl. viii, figs. 16-25.

Female.-Cephalothorax short, flattened, and of an oval shape; the dorsum chitinous and forming a shieldlike covering. Genital segment elongated, subcylindrical, proximal end narrower than the cephalothorax but becoming slightly enlarged towards the posterior extremity; distal end provided with two small cylindrical processes, one on each side of the minute abdomen. Egg-strings narrow, cylindrical, and tolerably elongated.

Antennules short, enlarged at the base; end joints three, narrow, and furnished with a few minute apical setæ. Antennæ, mandibles, and maxillæ similar to those of Lernæopoda elongata. First maxillipeds short, stout, armed with strong terminal claws. Second maxillipeds slender, considerably shorter than the body, and united at the tip to a chitinous disk or plug inserted into the tissues of the host. Length from the forehead to the end of the posterior appendages 13 to $14 \mathrm{~mm}$. Length of the posterior appendages fully $2 \mathrm{~mm}$., and of the second maxillipeds between 4 and $5 \mathrm{~mm}$.

Male.-The male is small. The cephalothorax is nearly equal in length to the genital segment, and the form is ovoid; genital segment elongate-ovate, fully twice as long as broad, and having at the distal end two short reflexed oval appendages, one on each side of the nearly obsolete abdomen. Both pairs of maxilli- 
peds short, stout, and furnished with strong terminal claws.

Habitat. - Found parasitic on various dog-fishes, usually adhering to the ventral and anal fins. At Polperro on the toper (Galeus vulgaris), and from $\operatorname{cod}$ (A. M. Norman). At Plymonth "from Galeus vulgaris, Mustelus vulgaris, and Acanthias vulgaris" (Bassett-Smith). Belfast, 1839 (W. Thompson). Off Valentia (W. F. Kane). Irish Sea $(A$. Scott). The Firth of Clyde, Moray Firth, Aberdeen (T. Scott).

\section{Lernæopoda cluthæ T. Scott.}

(Plate LX, figs. 1-3; Plate LVII, figs. 1-7; Plate LVIII, fig. 16.)

1900. Lernæopoda cluthæ T. Scott. (112) p. 173, pl. viii, figs. 27-37.

1909. Lernæopoda cluth: May E. Bainbridge. (3) p. 49, pl. 10, figs. $24-27$.

Female.-Cephalothorax small, subtriangular, a distinct and narrow neck connecting it with the posterior portion of the body, which is somewhat dilated and subcylindrical, and exhibits a few pseudo-constrictions. Two short processes springing from the distal end of the genital segment; the abdomen, situated between them, very small. The two pairs of antennæ similar to those of the species already described. Mandibles small and their biting margins, which are obliquely truncated, finely and somewhat irregularly serrated, and differing very markedly from the same appendages in Lernæopoda galei; maxillæ small, end joint provided with two tolerably long and stout terminal spines. 'The first maxillipeds more slender and rather more elongate than those of $L$. galei. Length, from the forehead to the end of the posterior appendages, $5 \mathrm{~mm}$.; length of the second maxillipeds nearly $3.5 \mathrm{~mm}$. Male. - 'I'he male differs considerably from that of the species just described (L. galei), particularly in the structure of the abdomen and of the caudal rami. In the species under consideration the abdomen of the male is distinctly segmented, and the caudal rami, 
which are not divergent, consist of two short slender processes instead of being broadly oval or claviform and reflexed upon the abdomen.

Habitat.-Parasitic on the gill-filaments of the Fuller's ray (Raia fullonica). Firth of Clyde, May, 1897 (T. Scott). Northumberland coast (May E. Bainbridge) on Raia radiata.

This species has not been observed on any of the dog-fishes, but only on the gill-filaments of the rays mentioned.

P. Olsson has described a Lernropodı (L. longimana) from the same species of skate.* 'The female only is described, and it appears from his description and figures to be distinct from the species recorded here.

\section{Lernæopoda salmonea (Linn.).}

(Plate LIX, figs. 1-6; Plate XLVIII, figs. S-1‥)

1761. Lernæa salmonea Linn. (77) p. 509, No. 2102.

1780. Lernæa salmonea Cordiner. (36) p. 7, 8, pl. 6, fig. 2.

1816. Entomoda salmonea Lamarck. (72) p. 233.

1822. Lerneopoda salmonea Blainville. (24) p. 127.

1837. Lernaopoda carpionis (?) Kröyer. (70, (1) pl. ii, fig. 6.

1840. Basenistes salmonea M. Edwards. (43) p. 509, pl. xli, fig. 3.

1850. I Lerneopoda salmonea Baird. (4) p. 335, pl. xxxv, fig. 6 .

1863. Lernæopoda salmonea Kröyer. (71) p. 275, pl. xiv, fig. $3 a-f$.

1900. Lernzopoda salmonea T. Scott. (112) p. 173, pl. viii, tig. 26.

Female.-Cephalothorax, seen from above, subtriangular, small, enlarged behind and distinctly separated from the posterior part of the body. The genital segment, where it joins the cephalothorax, narrowed and forming a kind of neck; the segment then becoming considerably enlarged and ovoid or pyriform, the posterior end rounded and provided with two minute apical knobs, one on each side of the abdomen which is very small.

The two pairs of antennæ and the appendages of the thorax somewhat similar to those of Lernxopoda. galei except that the second maxillipeds are tolerably stout and short, and the chitinous plug to which they

* "Prodr. fauna Copep. parasit. Scand.," 'Acta Universitatis Lundensis," 1869; 'Lunds Univ. Arsskrift,' iii, p. 30, pl. 2, figs. 13-15. 
are united at the tip is proportionally large. Entire length from the posterior end of the genital segment to the tip of the second maxillipeds about $6 \mathrm{~mm}$.

The male has not been observed by us.

Habitat.-Parasitic on the gills of the salmon. London Market (W. Baird): North of Ireland, 1856 (W. Thompson). Plymouth (Bassett-Smith). On a diseased salmon from the Firth of Tay (T. Scott). On "the gills of salmon taken in the Coquet, 1908"* (E. L. Gill). This species was also obtained on the gills of salmon by Thomas Edward of Banff. $\dagger$

A salmon captured in the river Dee near Aberdeen was infested by these parasites: they could be observed adhering to the ends of the gill-filaments in considerable numbers, the white colour of the parasites showing distinctly against the red colour of the gill filaments. (See Plate B, fig. 3).

\section{Lernæopoda bidiscalis W. F. de Visme Kane.}

\section{(Plate LXI, figs. 1, 2; Plate LVII, figs. 8-12.)}

1892. Lernxopoda lidiscalis W. F. de Visme Kane. (68) (3) vol. ii, p. 203, pls. ix, x.

1900. Lernæupoda bidiscalis T. Scott. (112) p. 172.

Female.-Cephalothorax, seen from above, oblong in shape and rather longer than broad, but in profile somewhat pyriform, sloping dorsally upwards and backwards, and terminating abruptly behind; a constriction which is distinct, but which can scarcely be described as a "neck," separating the cephalothorax from the genital segment. Genital segment short, considerably enlarged, and nearly as broad as long; an indistinct median dorsal groove present in some specimens, the posterior end somewhat truncated, and the postero-lateral corners rounded and slightly lobate. The genital segment provided with two short, intermediate, fusiform appendages which spring from the ventral aspect near the origin of the egg-strings. Abdomen nearly obsolete.

* $C f$. 'Crustacea of Northumberland and Durham,' by Brady and Norman (1910).

$\dagger C f$. Smiles, 'Life of a Scottish Naturalist,' 2nd ed. (1877), p. 437. 
Antennules nearly as in Lernæopoda galei. Antennæ very short, stout, and prehensile. The mandibles and other mouth-organs not differing much from those of I. galei. The second maxillipeds very short and stout, each terminating in a very large, fleshy, circular or ear-shaped disk; the disks united together by a horn-coloured chitinous plug. Colour usually opaquewhite, more or less tinged with red, sometimes highly coloured. Length: forehead to the end of the posterior appendages about $7 \mathrm{~mm}$., excluding the appendages, $5.5 \mathrm{~mm}$.

Male.-Though small, proportionally rather larger than the male of Lernæopoda galei, but in its general form and in the structure of its appendages having a close resemblance to the male of that species.

Habitat.-Parasitic chiefly on the claspers of male specimens of the tope (or toper), Galeus canis. On topers captured off Valentia, Ireland (de Visme Kane). Firth of Clyde (Mr. Duthie, Fishery Officer). Aberdeen $(T . S c o t)$. Irish Sea $(A . S c o t t)$. Taken also on the smooth hound. (Mustelus vulgaris) at Polperro, Cornwall by Mr. W. Laughrin about 1862 (A. M. Norman).

The dog-fishes on which these parasites were obtained were adult males, and they were usually found adhering on, or near the ends of, the claspers. We have rarely observed them on the claspers of young males. Moreover, as mentioned by the describer of the species, we almost invariably found that the ends of the claspers on which the parasites occurred were torn and bleeding, but whether the wounds were caused directly by the parasites, or through the efforts made by the fish to throw off its tormentors, was not very clear. Occasionally both claspers had parasites adhering to them.

The specimens observed by us had usually the front portion of the head of a bright red colour, and sometimes there were blotches of the same colour on other parts of the body; frequently also we found one, and more rarely two, males adhering to the feniale.

Among the more prominent features by which this Lernæopod is distinguished is the comparatively large size of the nearly circular disks which terminate the short second 
maxillipeds; the whole animal is also short and robust, and very different from the more elegant $L$. galei which is also sometimes met with at the base of the claspers.

\section{Lernæopoda similis sp. nov. (Plate LXI, figs. 3, 4.)}

Female.-Somewhat similar in general appearance to Lernæopoda cluth: but the head tolerably elongated; the second maxillipeds short, free except at the extremities, where they become united to a chitinous, horn-coloured button which penetrates the tissues of the host. Genital segment elongate-pyriform, widest posteriorly. Abdomen nearly obsolete, furnished with two tolerably long digitiform processes. Egg-strings long, narrow-cylindrical; ova small, numerous.

Mouth-appendages apparently somewhat similar to those of Lernxopoda cluthx. Colour yellowish grey. Length to the end of the posterior processes about $8 \mathrm{~mm}$.

Habitat.-Parasitic on the gills of the blue or grey skate (Raia batis) captured in the Firth of Clyde at Stations I and II in December 1899.

This species may be distinguished from $L$. cluthr, which - it somewhat resembles, by the short second maxillipeds, and by the form of the head.

\section{7. ? Lernæopoda lampri sp. nov. $\delta$.}

(Plate XXXIII, fig. 6; Plate XLIX, figs. 12-16.)

1901. ? Jernxopoda sp. ठँ, T. Scott. (113) p. 136, pl. viii, figs. 4-10.

"A few male specimens of what appears to be a species of Lernæopoda were obtained on the gills of an opah or king-fish, Lampris pelagicus (Gunn.)= Lampris luna, Gmel.), forwarded from Shetland to the Fishery Board's Laboratory at Bay of Nigg, 10th October 1900 ; no females were observed. . . The body of this parasite of the king-fish is comparatively slender; it tapers more or less gradually towards the 
posterior end. The antennules are small and fourjointed, the penultimate joint being shorter than the others. The antennæ are moderately robust except the last two joints, which are small, and the end joint is very feebly clawed. The mandibles are small, but somewhat similar in form and armature to those of Charopinus dalmanni. The maxillæ are also somewhat similar to those of that species, except that the ends are furnished with two instead of three spiniform appendages. The first and second maxillipeds are very robust and armed with short but powerful hooked terminal claws.

"The form of the various appendages shows a close relationship with the Lernæopodidæ, closer perhaps with Charopinus than with Lernæopoda."

The male specimens, of which the above is a short description, have been doubtfully referred to the genus Lernæopoda, but as they are considerably larger than the males of any species of that genus the females of which are known to us, they probably do not represent Lernæopoda at all, but if so, it is a genus closely related to it, as indicated by their form and anatomical details. One of the males figured in the Fishery Board's Report mentioned above measured $4.3 \mathrm{~mm}$. If the size of the female is of about the same proportion as we find it to be in some of the other species of the Lernæopoda, it should reach to about 16 or $18 \mathrm{~mm}$. in length.

\section{Genus 42. BRACHIELLA Cuvier, 1817.}

Nearly related to Lernæopoda, but the female differing in having the cephalothorax usually more. elongated and without a shield-like dorsum, the distance from the base of the second maxillipeds also being usually greater. The second maxillipeds separate except at the tip as in Lernæpoda, but usually shorter, rarely elongated. Genital segment short and robust, rarely elongate, and furnished with one, sometimes with two pairs of posterior appendages.

Male very minute; the cephalothorax and abdomen of nearly equal thickness and not very distinctly 
defined. Both pairs of maxillipeds large and uncinate.

T'he male shows a closer relationship with the male of Clavella than with that of Lernæopoda.

\section{Brachiella thynni Cuvier. \\ (Plate LXIV, figs. 4-6.)}

1817. Brachiella thynni Cuv. (37) p. 287 , pl. xv, fig. 5 .

1829-1843. Brachiella thynni Guérin-Méneville. (55) pl. ix, fig. $6 a-c$. 1832. Brachiella thynni Nordmann. (89) p. 90.

1840. Brachiella thynni M. Edwards. (43) p. 512.

1851. Brachiella thynni P. J. van Beneden. (11) p. 128.

1861. Brachiella thynni Stp. \& Lïtk. (127) p. 420 , pl, xv, fig. 36 .

1877. Brachiella thynni C. Vogt. (142) p. 426.

1896. Brachiella thynni Bassett-Smith. (7) p. 162.

1906. Brachiella thynni Norman \& T. Scott. (88) p. 219.

Female.-Cephalothorax slender, flexuose, fully as long as the genital segment, and separated from it by a more or less distinct articulation or constriction. Genital segment narrow at its union with the cephalothorax but becoming gradually enlarged towards the posterior end, where the width is equal to about half the length; the posterior end abruptly truncated and furnished with two pairs of elongated and moderately slender appendages, one pair springing in front of and the other behind the base of the egg-strings, which thus issue from between them, each having at its base an appendage both in front and behind; the appendages on the ventral aspect scarcely so elongated as the others, and about as long as the genital segment. That segment also somewhat flattened and with several transverse constrictions more or less indistinct, imparting to it an obscure lobate appearance.

Antennules small, three-jointed. Antennæ stout, moderately large, and furnished with a few apical spines. Mandibles narrow, elongated, inner margin near the distal end coarsely toothed, the teeth being to some extent alternately larger and smaller. Maxillæ small, furnished with two or three moderately stout apical setæ and one or two minute submarginal 
spines. First maxillipeds short, stout, and strongly uncinate. The second maxillipeds, which are equal to about two-thirds of the length of the genital segment, slender and free except at the tip, where they are joined to a reddish-brown coloured chitinous plug. Length from the forehead to the end of the posterior appendages of a full-grown specimen about $32 \mathrm{~mm}$.; length of cephalothorax about $14 \mathrm{~mm}$., of the genital segment about $9 \mathrm{~mm}$., and of the posterior appendages $9 \mathrm{~mm}$.

Male.-Very small, being about a millimetre in length; having a closer resemblance to the male of Lernæopoda than to that of a true Brachiella.

Habitat.-Parasitic on the gills of the tunny (Orcynus thynnus), and other nearly related fishes. Four specimens were obtained by Dr. Bassett-Smith on a tunny captured at Plymouth.

The female of this species is somewhat similar to B. rostrata in general appearance, but the cephalothorax is distinctly longer, and the posterior appendages are four in number and much more elongated.

\section{Brachiella rostrata Kröyer.}

(Plate XLV, fig. 8; Plate LXII, fig. 3 ; Plate LXIII, figs. 2-8.)

1837. Brachiella rostrata Kröyer. (70) Rekka 1, p. 207, pl. ii, fig. 1.

1840. Brachiella rostrata M. Edwards. (43) vol. iii, p. 415.

1863. Brachiella rostrata Kröyer: (71) p. 290 , pl. xviii, figs. 8, $a-i$.

1877. Brachiella rostrata C. Vogt. (142) p. 426.

1900. Brachiella rostrata T. Scott. (112) p. 174, pl. viii, figs. 38, 39.

Female.-Cephalothorax elongated, flexuose or vermiform, and separated from the genital segment by a more or less clearly-defined constriction. Genital segment narrow, subcylindrical, fully three times longer than broad and equal to about one and onethird times the length of the cephalothorax ; posterior end subtruncated and furnished with two subapical appendages. Abdomen obsolete or nearly so. The egg-strings, which are tolerably elongated, arising immediately outside of the subapical appendages. 
Antennules small, apparently four-jointed, but the articulation between the first two joints indistinct. Antennæ and mouth-organs somewhat similar to those of Brachiella thynni. The second maxillipeds springing from the lower half of the cephalothorax and reaching to about the proximal end of it; free except at the tip, where they are jointed to a horn-coloured chitinous plug. Length from the extremity of the cephalothorax to the end of the genital segment about $15 \mathrm{~mm}$., and $17 \mathrm{~mm}$. to the tip of the posterior appendages.

Male.-The male is nearly twice as long as broad and measures about $2 \mathrm{~mm}$. in length; it is comparatively robust, the cephalothoracic appendages are somewhat crowded together at the proximal end, and there is no distinct division between the cephalothorax and abdomen. The antennæ (both pairs), mandibles, and maxillæe are nearly as in the female; but both pairs of maxillipeds, though short, are furnished with strong terminal claws. Abdominal appendages very small.

Habitat.-Parasitic on the gills of halibut (Hippoglossus vulgaris). On large halibut captured in the North Sea, and landed at the Fish-Market, Aberdeen.

Kröyer records two forms, apparently distinct, under $B$. rostrata, one from the Hippoglossus here mentioned and the other-a shorter form-from Hippoglossus pinguis. This for'm we have not seen.

\section{Brachiella insidiosa Heller.}

(Plate XLVIII, fig. 18; Plate LXII, fig. 2; Plate LXIII, figs. 9-16.)

1865. Brachiella insidiosa Heller: (58) p. 239, pl. xxiv, fig. 1.

1896. Brachiella insidiosa Bassett-Smith. (6) vol. xviii, p. 14, pl. vi, fig. 2.

1900. Brachiella insidiosa T. Scott. (112) p. 175, pl. viii, figs. 40, 41.

1906. Brachiella insidiosa Brian. (21) p. 104, p]. viii, figs. 1 and 4.

F'emale.-Body tolerably robust. Cephalothorax short, flexuose, and vermiform. Genital segment 
subcylindrical, flattened, about two and a half times longer than broad; the width increasing slightly towards the posterior end, which is truncated and provided with two pairs of appendages. The two lateral appendages moderately elongated and slender, but the intermediate pair short, and springing from each side of the very small abdomen.

Antennules short and stout, and each composed of about three joints; antennæ robust, and somewhat similar to those of Lernæopoda galei. Mandibles narrow at the base but wider towards the posterior end, and armed with irregular coarse teeth on the obliquely-truncated distal extremity. Maxillæ small, simple, and provided with a few apical spines. First maxillipeds robust, and strongly uncinate; second maxillipeds short, and having the appearanee of being a prolongation of the cephalothorax. Length from the extremity of the cephalothorax to the end of the longer posterior appendages about $14 \mathrm{~mm}$. Eggstrings long and slender.

Male.-Very small, stout, about twice longer than broad and similar in structure to the male of Brachiella rostrata; the antennæ and both pairs of maxillipeds strongly uncinate.

Habitat.-Parasitic on the gill-rays of the hake (Merluccius vulgaris), moderately common. Plymouth (Bassett-Smith). Firths of Forth and Clyde, and at Aberdeen Fish-Market ('T. Scott). Irish Sea (A.Scott).

\section{Brachiella merluccii Bassett-Smith.}

\section{(Plate LXII, figs. 4, 5 ; Plate LXIII, figs. 17-20.)}

1896. Brachiella merluccii Bassett-Smith. (7) vol. iv, p. 163.

1896. Brachiella merluccii idem. (6) (6) vol. xviii, p. 14, pl. vi, fig. 1.

1900. Brachiella merluccii T. Scott. (112) p. 175, pl. viii, fig. 42.

1906. Brachiella merlucii Brian. (21) p. 107, pl. viii, fig. 3.

Female.-This species of Brachiella differs from most of the others by its bizarre appearance. Cephalothorax not very clearly defined from the genital portion of the body; bending round and forward at 
nearly a right angle to the dorsum, so that the animal appears to be very short and dilated when viewed from above. Genital segment considerably enlarged and furnished with two pairs of appendages; one pair moderately short prolongations of the posterolateral corners of the segment, the other pair tolerably elongated, springing from the ventral surface in front of the egg-strings, extending backward, curving round, and partly inclosing them.

Antennules stout and composed of three joints; the mandibles and maxillæ, as well as the second pair of antennæ, somewhat similar to those of Bractivella insidiosa; the first maxillipeds, however, scarcely so robust, but furnished with more powerful terminal claws. The second maxillipeds very short and enclosed together within a gelatinous envelope: though thus enclosed, not coalescent, but may be seen through the semi-transparent envelope extending alongside each other to where at the apex they are united to a hard chitinous plug. Length about $8 \mathrm{~mm}$.

Male.-We have not observed the male of this species, but Dr. Bassett-Smith describes it and states that the cephalothorax is large, and distinct from the posterior portion of the body, this portion being divided into five indistinct segments, and furnished at the posterior end with a pair of short two-jointed processes with pointed ends. The two pairs of antennæ, and the various other thoracic appendages, apparently similar to those of the male of Bracliella insidiosa.

Habitat.-Parasitic on the gill-rakers of the hake (Merluccius vulgaris), and not, like Brachiella insidiosa, attached to the gill-rays. Plymouth (Bassett-Smith). Firth of Forth and Aberdeen Fish-Market ('I'. Scott).

Brachiella merluccii does not appear to be so common as the species just alluded to; and the general structure of the female, and especially the partial union of the second maxillipeds, show, as pointed out by Dr. Bassett-Smith, a tolerably close relationship with Clavella (Anchorella). 
ร. Brachiella triglæ Claus.

(Plate LXII, fig. 1; Plate LXIII, figs. 21-25.)

1860. Brachiella triglix Claus. (30a) Würzburger naturwiss. Zeitschr., vol. i, p. 32, pl. i, fig. 6 .

1877. Anchorella triglæ Kurz. (71a) Zeitschr. f. wiss. Zool., vol. xxix, p. 404 , pl. xxv, figs. $13-15$.

1896. Brachiella triglix Bassett-Smith. (7) p. 163.

1901. Brachiella triglæ T. Scott. (113) p. 133, pl. vii, figs. 24-29.

Female.-Small but moderately stout; cephalothorax moderately short and flexuose; somewhat vermiform, and about as long as the genital segment. Genital segment considerably expanded, the width being rather greater than the length; lateral margins more or less irregularly lobate, and the postero-lateral produced into bluntly-rounded lobes; also provided with two short posterior appendages, situated one on each side of the nearly obsolete abdomen.

Antenmules short, tapering, and composed of four joints, end joint rather longer than the preceding one. Antennæ moderately short and stout, the end joint with a small terminal spike; outer ramus very short, biarticulated, and bearing two or three minute apical spines. Mandibles slender and obliquely truncated, the truncated margin being rather coarsely serrated; maxillæ moderately stout, bearing three elongated apical spines, and two others at the end of a small lateral process. First maxillipeds short, robust, and provided with small terminal claws. Second maxillipeds very short and stout, free except at the tips, where they are joined to a chitinous horn-coloured disk. Length about $4.5 \mathrm{~mm}$, varying slightly in different specimens.

Male-We have not observed the male of this species, but Dr. Bassett-Smith has figured one which apparently does not differ much from the males of other species of Brachiella.

Habitat.-Parasitic on the gills and gill-arches of Trigla spp. On Trigla gurnardus, cuculus, and limunclo at Plymouth (Bassett-Smith). On Trigla lineata, Firths of Forth and Clyde ('I'. Scott). It has also been

VOI. I. 
obtained on the gill-arches of Trigla lineata in the Adriatic.

\section{Brachiella ovalis (Kröyer). \\ (Plate LX, fig. 7 ; Plate LXIII, figs. 26-30.)}

1837. Anchorella ovalis Kröyer. (70) p. 289, pl. iii, fig. 6 .

1870. Anchorella ovalis P. J. van Beneden. (16) p. 31 , pl. ii, fig. 8.

1901. Brachiella ovalis T. Scott. (113) p. 133, pl. vii, figs. 30-35.

1904. Brachiella ovalis A. Scott. (109) No. 12, p. 44.

Female-Cephalothorax stout, moderately short, but rather longer than the genital segment. Genital segment subpyriform, considerably expanded posteriorly and narrowed at the proximal end to nearly the width of the cephalothorax; the posterior margin sloping backward slightly, and equally from both sides, and forming an obtuse angle at the base of the abdomen; a short submedian appendage occurring on each side of the abdomen midway between it and origin of the subglobular egg-strings, these appendages usually being more or less concealed by the eggstrings. Abdomen very small.

Antennules apparently composed of four joints, the first dilated and the others small, the third being much shorter than either the second or fourth. Antennæ tolerably large; end joint narrowly rounded at the apex and covered with minute bristles, the outer ramus consisting of two small subequal joints bearing three very small apical spines. Mandibles moderately stout and slightly expanded towards the distal end, the inner margin at this end being armed with a series of somewhat coarse teeth, alternately larger and smaller. Maxillæ and first maxillipeds somewhat similar to those of Brachiella triglæ. Second maxillipeds very short, stout, and recurved, free except at the distal end, where they are united to a chitinous plug fixed in the gill-arches of the host. Length about $3.5 \mathrm{~mm}$.

We have been unable to obtain the male of this species. Habitat.-Parasitic on the gill-arches of Trigla 
gurnardus. Moray Firth, in April and May 1900 (T. $S c o t t)$. Irish Sea $(A$. Scott). Apparently more frequent on young fishes than on adults. Both Kröyer and P. J. van Beneden record this Brachiella from Trigla gurnardus.

\section{Brachiella bispinosa Nordmann.}

(Plate L, fig. 9 ; Plate LXIV, fig. 9.)

1832. Brachiella bispinosa Nordmann. (89) p. 94, pl. viii, figs. 4-7.

1840. Brachiella bispinosa M. Edwards. (43) p. 513.

1877. Brachiella bispinosa C. Vogt. (142) p. 456.

1901. Brachiella bispinosa T. Scott. (113) p. 132.

1906. Brachiella bispinosa Norman \& T. Scott. (88) p. 220.

Female.-Cephalothorax narrow, rather shorter than the genital segment and usually more or less doubled back upon it. Genital segment seen from above oblong or somewhat lyre-shaped, nearly twice longer than broad; posterior end broadly rounded, not angular, and provided with two small submedian spiniform appendages.

Antennules short, slender, and composed of three or four joints. First maxillipeds strongly uncinate. Second maxillipeds scarcely reaching to the end of the cephalothorax, free but united at the apex to a round chitinous knob. Length about $8 \mathrm{~mm}$.

We have not seen the male of this species, but Dr. Bassett-Smith states that it resembles the male of Thysanote impudica (Nordmanu).*

Habitut.-Parasitic on the gill-arches of Trigla spp. Plymouth, on Trigla cuculus, Trigla gurnardus, and Trigla lyra (Bassett-Smith). Moray Firth, on Trigla sp. (T. Edward: 'Museum Normanianum').

8. Brachiella pastinaca P. J. van Beneden. (Plate LXIV, fig. 8.)

1851. Brachiella pastinaca P.J.van Beneden. (11) p.118, pl. 4. figs. 8. 9. 1877. Brachiella pastinaca Kurz. (7la) Zeitschr. f. wiss. Zool., vol. xxix, pls. $25,26,27$, figs. $2,3,36,45$.

1S50. Brachiella pastinaca A. Valle. (141a) Boll. Soc. Adriat. Sc. Nat.. vol. iv, fasc. i, p. 77.

1904. Brachiella pastinaca T. Scott. (115) p. 278.

* 'Journ. Mar. Biol. Assoc.' (x.s.), vol. iv, No. 2 (February 1896), p. 163. 
1906. Brachiella pastinacæ Brian. (21) p. 103.

1909. Brachiella pastinaca May E. Bainbridge. (3) p. 50, pl. 8, figs. 6,7 ; pl. 9 , fig. 8 .

Female. - Cephalothorax tolerably enlarged and somewhat gibbous behind on the dorsal aspect, connected with the genital segment by a narrow neck. Genital segment oblong, robust, and at the distal end bearing two slender submedian appendages nearly half as long as the segment. Abdomen obsolete or nearly so.

Antennules moderately slender and four-jointed; antennæ stout, composed of two joints, and furnished with a small rudimentary outer ramus. Mandibles tolerably slender and armed with several coarse teeth at the distal end of the inner margin. The first maxillipeds tolerably large and strongly uncinate. The second maxillipeds nearly as long as the cephalothorax, free except at the tips where they are united to a horn-coloured chitinous plug. Length about $7 \cdot 5 \mathrm{~mm}$.

Habitat.-Parasitic in the nasal fossæ of T'rigon pastinaca and also of the piked dog-fish (Acanthicts vulgaris). In the nasal fossæ of a Trigon captured in the Dornoch Firth in October, 1903 ( $T$. Scott). In the spiracle of a spiked dog-fish captured off the coast of Northumberland (Ma!! E. Bainbridge).*

\section{Brachiella parkeri G. M. Thomson. (Plate LXIV, fig. 7.)}

1889. Brachiella parkeri Thomson. (132) p. 374, pl. 10, figs. 18-23.

1909. Brachiella parkeri May E. Bainbridge. (3) p. 52, pl. 9, figs. 16,17 ; pl. 10, figs. 18-23.

Female.-Cephalothorax moderately stout, deflected so as usually to be nearly at right angles to the genital segment, and equal to about two-thirds the length of it. Genital segment of an ovate form, moderately dilated, and provided with two elongated and rather slender distal appendages, one on each side of the papilliform abdomen. Antennules moderately elongated, slender, and composed of two articulations; antennæ some-

* Miss May Evelina Bainbridge, now the Hon. Mrs. Henn Collins. 
what similar in structure to those of Brachiella pastinaca. Rostrum somewhat prominent; mandibles slender, their inner margins armed at the distal end with about four tolerably large teeth and with smaller teeth between. Maxillæ of the usual type, resembling those of Brachiella triglæ. First maxillipeds stout but somewhat rudimentary and only feebly uncinate; second maxillipeds long and slender, fully twice the length of the cephalothorax, and entirely free except at the tip, where they are united to a chitinous horncoloured disk.

Habitat.-Obtained on the gills of a long-nosed skate (Raic oxyrhynchus) captured off the Northumberland coast in May 1908 (May E. Bainbridge).

We have not met with this species, but Miss Bainbridge, in her paper referred to above, gives a careful description of it. Her description and drawings agree very well with those of G. M. Thomson. The following measurements of the specimen examined are given by Miss Bainbridge :-

Length from top of arms to end of abdomen $\quad 9 \cdot 2 \mathrm{~mm}$.

" from end of head to extremity of

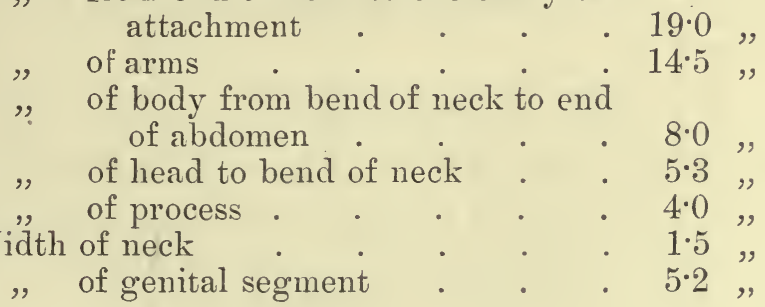

\section{Genus 43. CLAVELLA Oken, 1815.}

Syn. Schisturus Oken (1815), a name preoccupied by Rudolphi (1809) for a genus of Vermes. Anchorella Cuv. (1817). Lerneomyzon Blainville (1822).

Female.-Body usually short and somewhat swollen. Head small, situated at the end of a long flexuous neck which is usually more or less deflexed. Both pairs of antennæ small and somewhat rudimentary; the mandibles, maxillæ, and first maxillipeds resembling those in Lernxopoda, and, together with the two 
pairs of antennæ, placed at the end of the elongated neck, or cephalothorax. The second maxillipeds, by which the parasite fixes itself to its host, situated at the base of the cephalothorax, and coalescent so that they appear to consist of a single organ; this organ is usually short, sometimes very small and papilliform, and united at the tip to a horn-coloured chitinous plug which penetrates the tissues of the fish. Genital segment usually unprovided with terminal or lateral processes, but if present they are generally very small. Abdomen obsolete or nearly so. Egg-strings moderately elongated.

Male.-The male is very small and proportionally shorter than the male of Brachiella, which it more nearly resembles than that of the genus Lernæopoda; the dorsum, however, is more boldly arched, and the height is usually greater than the length. The appendages of the cephalon and thorax are somewhat similar to those of the male of Brachielln.

The genus comprises a large number of species, and those described below have been obtained on British fishes.

\section{Clavella uncinata (O. F. Müller).}

\section{(Plate LXV, figs. 2, 3, 6; Plate LXVI, figs. 21-23.)}

1777. Lernaxa uncinata O. F. Müller. (\$5) p. 120, pl. xxxiii, fig. 2.

1815. Schisturus uncinatus Oken. (91) part iii, p. 183.

1815. Clavella uncinata idem. (91) part iii, p. (?) 357.

1817. Anchorella uncinata Cuv. (37) Icon. du Règne Anim., pl. 9. fig. 5 .

1822. Lerneomyzon uncinatum Blainville. (24) Journ. de Physique, vol. 95 , p. 438 .

1832. Anchorella uncinata Nordmann. (89) p. 102, pl. 8, figs. 8-12; pl. 10, figs. 1-5.

1850. Anchorella uncinata Baird. (4) p. 337, pl. xxxv, fig. 9.

1900. Anchorella uncinata T. Scott. (112) p. 177, pl. viii, figs. 43, 44.

1906. Clavella uncinata Brian. (21) p. 110.

1909. Anchorella uncinata May E. Bainbridge. (3) p. 57, pl. ii, figs. 43-46.

Female.-Cephalothorax moderately slender and about as long as the genital segment. Genital segment ovate, slightly flattened, and moderately elongated, 
being fully twice as long as broad. Abdomen small but quite distinct.

Antennules three-jointed, the proximal joint large but tapering towards the distal end; other joints small and subequal but the end one rather the larger. Mandibles small, biting part serrated on the inner edge. Maxillæ small, expanded towards the distal end, with the outer margin somewhat gibbous; each bearing a couple of terminal spines and also a small subterminal lobe with two spinules at its apex. The first maxillipeds rather diminutive in size but provided with moderately stout terminal claws. The second maxillipeds completely coalescent, very short, expanded at the apex, and fixed to a nipple-like plug which penetrates the tissues of the fish. Egg-strings tolerably slender and fully twice as long as the genital segment. Length of the specimen represented by figure 2, Pl. LXV, exclusive of the cephalothorax, about $6.5 \mathrm{~mm}$., but the size is somewhat variable.

Male.-The male is very small, and, viewed laterally, the height is equal to about one and a half times the length; the dorsum tapers upwards and assumes a somewhat conical ontline, but with the apex boldly rounded. Both pairs of maxillipeds short but tolerably stout and strongly uncinate; other cephalothoracic appendages small and somewhat rudimentary. Length about $1 \mathrm{~mm}$.

Habitat.-Found parasitic on the whiting (Gadus merlangus) and other Gadoids. This tolerably common species has been recorded from various places round the British coasts. Larne and Dublin (W. Thompson). Polperro and Falmouth (A. M. Norman). Plymouth (Bassett-Smith). Irish Sea (A. Scott), and also from various Scottish localities.

A young Clavella uncinava with two males adhering to it is represented by fig. 6 on Pl. LXV. In this specimen the genital segment is much less robust, and the mouthappendages are more rudimentary. 


\section{Clavella rugosa (Kröyer).}

\section{(Plate LXV, figs. 4, 5 ; Plate LXVI, figs. 1-7.)}

1837. Anchorella rugosa Kröyer: .70) pl. 1, vol. i, p. 294, pl. iii, fig. 6. 1550. Anchorella rugosa Baird. (4) p. 338, pl. xxxv, fig. 8 .

1851. Anchorella rugosa P. J. van Beneden. (11) p. 114, pl. vi, fic. 7. 1900. Anchorella rugosa T. Scott. (112) p. 176, pl. viii, figs. 45-48.

Female.-Cephalothorax tolerably elongated and vermiform, about one and a half times longer than the genital segment; usually more or less recurved and reaching considerably beyond the distal end of the segment. Genital segment stout, rugose, quadriform, and somewhat flattened, length and width about equal. Abdomen obsolete or nearly so.

Antennules composed of three joints, the first moderately large and stout, the other two smaller but the end joint rather longer than the preceding one; antennæe stout and somewhat similar in structure to those of Brachiella. Mandibles small, slender, and coarsely dentate near the distal end of the inner margin. Maxillæ furnished with three moderately stout terminal spines, and two smaller ones on a somewhat rudimentary subterminal lobe. First maxillipeds short, stout, and strongly uncinate. Second maxillipeds rudimentary, being reduced to a small button-like projection at the anterior end of the genital segment, which is fixed to a horn-coloured chitinous plug that penetrates the tissues of the fish. Egg-strings tolerably stout and elongated, more than twice the length of the genital segment, and containing numerous ova. Length exclusive of the cephalothorax about $4 \mathrm{~mm}$., but the size is slightly variable.

Male.-The male is very small and short, the height being equal to fully one and a half times the length; the general outline, seen from the side, is subconical. Both pairs of maxillipeds, though short, are furnished with stout terminal claws.

Hatitat.-Parasitic on the gills and gill-covers of cat-fishes (Anarrhichas lupus). On cat-fishes captured 
in the Firths of Forth and Clyde, off Aberdeen, and in the Moray Firth (T'. Scott). Off the coast of Northumberland and Durham (May E. Bainbridge). Larne, Ireland (W. Thompson).

\section{Clavella dubia T. \& A. Scott.}

\section{(Plate LXV, fig. 7 ; Plate LXVI, figs. 8-11.)}

1900. Anchorella rugosa var. T. Scott. (112) p. 177, pl. viii, fig. 52.

F'emale.-Generally resembling the female of $C$.uncinatus, but having the cephalothorax rather shorter, and the second maxillipeds or fixative organ scarcely so prominent; the genital segment also being more robust.

Antennules short and three-jointed, the first joint robust, but tapering quickly towards the-distal end; the second small, and the end one about twice as long as the preceding joint, and very sparingly setiferous at the apex. Mandibles tolerably stout, somewhat expanded near the middle, and the biting part of the inner margin provided with about four coarse teeth and two or three smaller ones; the first two teeth nearly close together, a slight gap in which is a small denticle dividing these two from the next one, but a considerable distance separating it from the end tooth, and the intervening space occupied by two denticles. Maxillæ moderately elongated, and provided with two narrow terminal lobes ending in tolerably long spines. First maxillipeds short, moderately robust, and possessing fairly stout terminal claws.

Habitat.-Found adhering to a haddock (Gadus xglefinus) from the North Sea.

'This form was at first regarded as a variety of Clavella rugosa, but further examination reveals differences both in its form and structure which, though showing some relationship with its two nearest allies, $C$. rugosa and $C$. uncinata, cannot be reconciled with either. We therefore prefer to describe it under a distinct name. 


\section{Clavella emarginata Kröyer.}

(Plate LXIX, fig. 7 ; Plate LXVI, fig. 17-20.)

1837. Anchorella emarginata Kröyer. (70) pl. i, vol. i, p. 287, pl. iii, fig. vi. 1851. Anchorella emarginata P. J. van Beneden. (11) p. 113, pl. vi, fig. 4. 1877. Anchorella emarginata Kurz. (71a) Zeitschr. f. wiss. Zool., vol. xxix, p. 398, pl. xxv, fig. 8 .

1900. Anchorella emarginata T. Scott. (112) p. 176, pl. viii, figs. 49-51. 1906. Clavella emarginata Brian. (21) p. 109, pl. x, fig. 3.

Female.-Cephalothorax very long and slender, twice as long as the genital segment; head small and separated from the long neck by a slight constriction. Genital segment subquadriform, considerably dilated, and somewhat truncated at the posterior end. Abdomen obsolete or nearly so. Egg-strings short and tolerably thick.

Antennules short, composed of three articulations. Mandibles small and armed with only moderately large teeth; maxillæ narrow, provided with three apical spines and with two small ones on a rudimentary branch near the middle of the joint. First maxillipeds moderately small and uncinate. Second maxillipeds moderately thick, very short, and not completely united except at the tip, where they are joined together to a chitinous plug. Length.- The specimen represented by the drawing measures, exclusive of the cephalothorax, about $2.5 \mathrm{~mm}$., while the cephalothorax alone measures $3 \cdot 5 \mathrm{~mm}$.

We have not seen the male of this species.

Habitat.-Parasitic on the gill-arches of the allis shad (Clupea alosa) and of the twaite shad (Cluper finta). Plymouth on Clupea (Bassett-Smith). Dunbar, Firth of Forth, on Clupea finta (T. Scott).

This species is readily distinguished by the long, slender cephalothorax, the dilated genital segment, and by the imperfectly united second maxillipeds.

\section{Clavella scombri Kurz.}

(Plate LXVII, figs. 1-3 ; Plate LXVIII, figs. 1-7.)

1877. Anchorella scombri Kurz. (71a) Op. cit., p. 403, pl. xxv, figs. 12 , 35,41 . 
1901. Anchorella scombri T. Scott. (113) p. 135, pl. viii, fig. 3 .

1906. Anchorella scomberi A. Scott. (110) p. 53, pl. vii.

1906. Clavella scombri Brian. (21) p. 116, pl. x, fig. 6.

Female.-Cephalothorax extremely elongated, flexuose, vermiform, and nearly three times as long as the genital segment, the proximal half moderately stout, the distal portion rather more slender. Moreover, the proximal portion of the cephalothorax bends gently downwards, but near the middle there is a somewhat abrupt change of curvature in the opposite direction, which causes the cephalothorax to assume a geniculated or sigmoid appearance. Genital segment of a subglobular form, rather longer than broad, and small in comparison with the cephalothorax, also appearing to be unprovided with distal appendages of any kind. Abdomen rudimentary or obsolete. Egg-strings small and saccate.

Antennules small, two-jointed, and furnished with a few small apical setæ. Antennæ short, stout, and somewhat rudimentary; outer ramus very small. Mandibles and other mouth-organs similar to those of Clavella emaryinata. Second maxillipeds entirely coalescent, extremely short, and united at the apex to a small horn-coloured chitinous plug. Length, exclusive of the cephalothorax, about $2 \cdot 5 \mathrm{~mm}$. Length of cephalothorax fully $6 \mathrm{~mm}$.

Male.-Extremely small, and its form that which appears to be characteristic of the males of this genus, being very short and with the dorsum elevated so that the height is distinctly greater than the length. Both pairs of maxillipeds short, stout, and strongly uncinate.

Halitat.-Parasitic on the gill-arches of mackerel (Scomber scombrus). Found on mackerel captured in the neighbourhood of Aberdeen in August, 1900 (T. Scott). On mackerel captured in the Irish Sea off Walney Island, and in Carnarvon Bay in 1905 (A. Scott). Recorded by Dr. Ed. Graeffe as parasitic on mackerel captured in the Gulf of Trieste.*

* 'Arbeiten der zoolog. Institut zu Wien,' 'T. xiii, Heft 1, p. 17 (1900). 


\section{Clavella brevicollis M. Edwards.}

\section{(Plate LXV, fig. 1; Plate LXVI, figs. 12-16.)}

1840. Anchorella brevicollis M. Edwards. (43) vol. iii, p. 518.

1877. Anchorella brevicollis C. Vogt. (142) p. 432.

1901. Anchor-lla brevicollis T. Scott. (113) p. 135, pl. viii, figs. 11-16.

Female.-Resembling Clavella uncinata in some respects but differing considerably in the following particulars: cephalothorax comparatively much shorter and stouter, and appearing rather to be a prolongation of the posterior portion of the body forwards, the only limitation being a slight constriction immediately behind the second maxillipeds. Genital segment subglobular, rather longer than broad, and without posterior appendages. Abdomen small, distinct. Antennules short, two-jointed, basal joint large, end joint small and furnished with a few apical setæ. Antennæ simple, rudimentary, but stout and apparently uniarticulate. Mandibles slender, their armature consisting of a few comparatively large teeth with intermediate smaller ones. Maxillæ moderately stout, provided with two subapical processes bearing short terminal spines, and two minute lateral spines on the same side as the processes. The first maxillipeds large, with strong terminal claws. The second maxillipeds entirely coalescent, very short and stout, and terminating in a chitinous knob. Length about $4.5 \mathrm{~mm}$.

Male not observed.

Habitat.-Parasitic near the base of the anal fin of a haddock captured in the Firth of Forth in January 1896. P. J. van Beneden records this species as parasitic on the body (not on the gills) of haddocks; so also does M. Edwards.

\section{Clavella stellata (Kröyer).}

(Plate LXV, figs. 8, 9.)

1837-1838. Anchorella stellata Kröyer. (70) pl. i, vol. ii, p. 142, pl. iii, fig. 5 .

1877. Anchorella stellata C. Vogt. (142) vol. xiv, p. 432. 
1900. Anchorella stellata T. Scott. (112) p. 178.

1901. Anchorella stellata idem. (113) p. 134, pl. viii, figs. 1, 2.

1909. Anchorella stellata May E. Bainbridge. (3) p. 57, pl. ii, figs. $38-42$.

Female.-Cephalothorax tolerably elongated and slender, and appearing to be but a prolongation of the coalescent second maxillipeds, having the headappendages at the end of it. Genital segment short, moderately stout, ovoid in shape, and joined to the cephalothorax by a narrow neck. Abdomen rudimentary, appearing as a slightly produced middle portion of the posterior end of the genital segment; on each side of the abdomen a small tubercle, which, with the rudimentary abdomen, imparts a slightly trilobed appearance to the end of the segment.

The two pairs of antennæ, the mandibles, and other mouth-organs are apparently similar to those of Clavella uncinata. The whole animal including the maxillipeds appeared to be, in the living state, surrounded by semi-transparent gelatinous matter through which some of the structures could be plainly seen ; the two second maxillipeds were visible within the gelatinous investment, extending alongside each other to where they joined the chitinous disk by which the parasite was anchored to its host. All the specimens observed were fixed to scales, and the chitinous fixture, after piercing the outer surface of the scale, spread out into an extremely thin and dark horn-coloured circular disk; the disk was ornamented all round with pellucid, oval markings arranged at more or less regular intervals and in the manner of radii which did not quite extend to the circumference of the disk. The parasite could not easily be removed without also removing the scale to which it was attached or by severing the attachment where it penetrated the scale. The specimen represented by the drawing (Pl. LXV, fig. 8) measured from the forehead to the apex of the second maxillipeds about $6 \mathrm{~mm}$., and the genital segment about $4 \mathrm{~mm}$. in length by fully $2 \mathrm{~mm}$. in thickness. 
No males have been observed.

Habitat.-Parasitic on the skin of the hake (Merluccius vulgaris). The specimens were found adhering to scales near the base of the pectoral and ventral fins of a hake captured in the Firth of Clyde in December 1899. The whole parasite was enveloped in some soft, nearly transparent, jelly-like matter, and at first sight had the appearance of a small roundish mass of mucus, and thus easily escaped notice: when preserved, the mucus assumed a whitish colour. Miss Bainbridge (op. cit.) described some specimens found on the skin of a hake, "purchased at Sheringham, Norfolk."

\section{Clavella paradoxa P. J. van Beneden.}

\section{(Plate LXVII, figs. 4-6; Plate LXVIII, figs. 8-14.)}

185̌1. Anchorella paradoxa P. J. van Beneden. (11) vol. xvi, p. 117, pl. vi, fig. 1 .

1896. Anchorella paradoxa Bassett-Smith. (6) p. 15, pl. v, fig. 2.

1906. Anchorella paradoxa A. Scott. (110) p. 53, pl. vii.

Female.-Cephalothorax tolerably elongated, usually deflected backward upon the genital segment, and extending somewhat beyond its distal end. Genital segment subquadriform, the postero-lateral corners prolonged backward and slightly outward in the form of narrow subtriangular processes, their width at the base being equal to about half the length and with the apex bluntly pointed; genital segment exclusive of the lateral prolongations about as broad as long. Abdomen intermediate between the processes, comparatively rather longer than broad and bluntly rounded at the end. Three shallow knobs at the anterior end of the genital segment, on the dorsal aspect, one on each of the flatly-rounded corners, and one intermediate and somewhat behind the others; two similar but smaller knobs also present on the forehead as shown in the figure (Pl. LXVII, fig. 4).

Antennules nearly as in Clavella scombri, but the antennæ, which are three-jointed, are scarcely so 
robust. Mandibles somewhat similar to those of that species, but the maxillæ are slender and provided with three digitate terminal processes. First maxillipeds similar to those of Clavella scombri; second maxillipeds very short, coalescent, and fixed to a terminal chitinous plug. Length, exclusive of the cephalothorax, about $4 \mathrm{~mm}$.

Male.-Very small, nearly globular in shape, and somewhat similar in structure and appendages to the males of other species of Clavella.*

Habitat.-Parasitic on the gill-filaments of mackerel (Scomber scombrus). Plymouth (Bassett-Smith). Irish Sea $(A$. Scott).

\section{Clavella quadrata Bassett-Smith. (Plate LXVIII, fig. 15.)}

1896. Anchorella quadrata Bassett-Smith. (6) p. 15, pl. iv, fig. 5 . 1899. Anchorella quadrata idem. (8) p. 504.

1906. Anchorella quadrata Norman \& T. Scott. (88) p. 221.

Female.-Cephalothorax much longer than the genital segment. Genital segment almost quadrilateral in outline. Abdomen of extraordinary size for animals of this genus; somewhat club-shaped, and equal to about two-thirds the length of the genital segment. Egg-strings small and broadly ovate. First pair of maxillipeds placed close to the mouth, well developed; second pair short, opposite to the abdomen and at the base of the neck, thick and completely united, terminating in the organ of adhesion, which has the form of a cup with a long pedicel.

This species is much like Anchorella falax Heller, in form, except for the great size of the abdomen.

The male has not been observed.

Habitat.-Parasitic on the gill-arches of Callionymus: lyyra, at Plymouth; only a few specimens were obtained (Bassett-Smith).

* One of the authors, when first recording the male of C.paradoxa, states that he could only find one pair of maxillipeds (see 'Trans. Biol. Soc. Liverpool,' vol. xx, p. 53, 1906). 'This was evidently due to the second pair having been accidentally destroyed: he has since found that there are two pairs, as in other males of the same gemus. 
The above is quoted from Dr. Bassett-Smith's description of this species, as we have not ourselves observed it.

\section{Clavella canthari (Heller). (Plate LXIX, figs. 1-3.)}

1863. (?) Anchorella pagelli Kröyer. (71) p. 295, pl. xvi, fig. 3. 1865. Anchorella canthari Heller. (58) p. 242, pl. xxiv, fig. 6 . 1877. Anchorella pagelli C. Vogt. (142) p. 432. 1880. Anchorella canthari Richiardi. (104) p. 152. 1906. Clavella macrotrachelus Brian. (21) p. 116. 1910. Lerneomyzon canthari T. R. R. Stebbing. (125) p. 562.

Female.-Small and tolerably robust, but the cephalothorax is rather slender and considerably longer than the genital segment, being equal to fully one and a half times the length of that segment; the proximal end of the cephalothorax bluntly rounded and on each side bearing a small but fairly distinct lobe; a minute process arising from between the two lobes, and terminating in a fascicle of chitinous bristles which penetrates the tissue of the gill filament and then gradually becomes separated and forms a brush-like appendage. Genital segment moderately stout and subcylindrical, the width equal to rather more than half the length. A small gibbous projection at the proximal end of the segment, as viewed from the side, separated from the segment by a fairly distinct constriction, and forming the base of the cephalothorax. The distal end of the genital segment truncated and obscurely trilobate, but only the middle lobe fairly distinct; the lateral lobes indistinct and scarcely produced, but the middle one fairly prominent and thickly covered with minute hairs. Egg-strings moderately elongated. Length.The following measurements are taken from a fairly typical specimen :-

Genital segment .

about $1.8 \mathrm{~mm}$.

Cephalothorax .

Egg-strings

about $2 \cdot \check{\mathrm{mm}}$.

about $3 \cdot 0 \mathrm{~mm}$.

Male.-Small, somewhat similar to the male of $C$. alata, Brian.

Habitat.-Parasitic on the gill-filaments of the black 
sea-bream (Cantharus lineatus) and the common seabream (Pagellus centrodontus). On Cantharus lineatus, captured in the North Sea in November 1910, as well as on a few subsequent occasions. Kröyer obtained what appears to be the same species on Pagellus centrodontus.

The characters by which this species seems to be distinguished are the proportional length of the cephalothorax, the small lobe on each side of its promixal end, the peculiar appendage by which the species is anchored to the gill filament, and the densely ciliated central lobe of the posterior margin of the genital segment. Some of the specimens examined by us have exhibited slight differences, but they all agree in the more important characters mentioned above.

\section{Clavella alata Brian.}

\section{(Plate LXIX, figs. 4-6.)}

1906. Clavellu alata Brian. (21) p. 114, pl. iii, fig. 5 ; pl. xx, figs. 5 and 6 .

Female.-Short and stout. Cephalothorax reaching only to about, or slightly beyond, the end of the genital segment; at the base of the cephalothorax a small horn-like process projecting outwards on each side. The second maxillipeds apparently completely coalescent, very short, tapering slightly towards the tip, which is provided with a rounded cartilaginous knob. Genital segment short and stout, subglobose or pyriform, greatest width about equal to the length, posterior end subtruncate or broadly rounded; the middle portion, however, slightly produced, and on each side of this slightly produced part is the attachment of the short and tolerably stout ovisacs. The antennules, antennæ, and several mouth-appendages apparently not differing greatly from those of other species of the genus. Antennules short, moderately stout, indistinctly segmented, and bearing a few apical setæ; mandibles very slender, but the first maxillipeds tolerably enlarged and uncinate. The entire length, exclusive of the egg-strings, is about $3 \mathrm{~mm}$., while the egg-strings are about $2 \mathrm{~mm}$. in length. Colour yellowish. 
The males, which are very small, measure only about $0.3 \mathrm{~mm}$., and are provided with large uncinate maxillipeds. Males, however, do not appear to be very common.

Habitat.-Parasitic on the greater fork-beard (Phycis blennoides (Brïn.)). It is usually found adhering to the gill-arches and not to the filaments of the gills.

One of the more obvious characters of this species seems to be the small but quite distinct horn-like processes at the base of the cephalothorax, which can be seen-one on each sideextending outwards at about right angles to the cephalothorax.

\section{Clavella lophii (M. Edwards).}

\section{(Plate LI, fig. 7.)}

1840. P Brachiella lophii M. Edwards. (42) vol. iii, p. 514, pl. xli, fig. 4. 1877. P Brachiella lophii Vogt. (142) vol. vi, p. 426.

Female.-A small and robust species. Cephalothorax moderately short, subcylindrical or subconical, stout but less robust in front. Genital segment somewhat dilated, widest posteriorly, postero-lateral corner's rounded. Abdomen very short. Egg-strings short, saccate, rather longer than the genital segment, and containing tolerably large ova.

Mouth-appendages apparently somewhat similar to those of C.rugosa. The second maxillipeds very short and coalescent, and terminating in a small, horncoloured, chitinous button. . Colour of the specimen yellowish. Length about three and a half millimetres. Male.-Very small and of the usual Clavella (Anchorella) type; short, and with the dorsum boldly arched.

Habitat.-Found adhering to the gills of an anglerfish (Lophius piscatorius); locality uncertain.

We are indebted to Mr. W. M. Tattersall, M.Sc., Keeper of the Manchester Museum, for the privilege of describing this species. The drawing is made from the mounted specimen. 


\section{Genus ARGULUS Müller, 1785.}

Body flattened, cephalothorax scutiform; cephalon and first thoracic segment coalescent; other segments free. Abdomen small, comparatively narrow, and ending in two equal lobes, unsegmented. Antennæ two pairs, small, first pair tolerably stout and terminating in a small hook. Mouth siphon-like, enclosing a flexible, sharp-pointed, sting-like process furnished with a poison-gland. Two pairs of maxillipeds, the first pair transformed into sucking-discs; posterior pair prehensile, their integument rough with minute prickles, and having a tridentate plate on the inferior aspect of the basal joint. Swimming-legs four pairs, biramose, and furnished with plumose hairs. Females without external egg-strings. Eyes conspicuous.

\section{Argulus foliaceus (Linn.). \\ (Plate LXXII, figs. 1-10.)}

1758. Monoculus foliaceus Linn. Systema Naturæ, 10th edit., vol. i, p. 634 .

1762. Binoculus gasterostei Geofroy. Insectes de Paris, vol. ii, p. 661.

1785. Argulus foliaceus Müller. Entomost., p. 123.

1785. Argulus charon idem. Ibidem, pl. 20, figs. 1, 2.

1793. Monoculus arguluso Fabr. Entom. Syst., vol. ii, p. 489.

1798. Monoculus gyrini Cuvier. Tab. élément. Hist. Nat., p. 45.

1802. Ozolus gasterostei Latreille. Hist. Nat. Crust. et Ins., vol. iv, p. 128, pl. 29, fig. 4 .

1814. Argulus argulus Leach. Edin. Encyclop., vol. vii, p. 388.

1839. Argulus foliaceus Thompson. Ann. and Mag. Nat. Hist., vol. v, p. 221.

1845. Argulus foliaceus Vogt. Nouv. Mém. Soc. Helvét., vol. vii, pl. i, fig. 2.

1850. Argulus foliuceus Baird. Entom., p. 255, pl. xxxi, figs. 1, $2 a-l$.

Carapace of a rounded oval shape, rather longer than broad, and with the front margin slightly projecting forward ; posterior sinus narrow and extending forward for about two-fifths of the carapace. Abdomen small, rather longer than broad, and about onefourth the length of the cephalothoracic shield; lobes bluntly rounded at the end, separated by a sinus extending forward to about half the length of the 
abdomen; inner edges proximally contiguous and somewhat divaricate at the distal extremity. Antennæ normal. Sucking-discs of moderate size. Posterior maxillipeds tolerably large and stout, their basal plates somewhat expanded posteriorly ; the distal margin of the plates with three short and subequal tooth-like projections. Swimming-legs tolerably elongated. Eyes conspicuous. A black mark on each side near the base of the abdomen. Carapace of a greenish colour and ornamented on both sides with darker coloured ramifications. Size of the female about 6 or $7 \mathrm{~mm}$. in length. Male somewhat like the female, but smaller.

Habitat.-Parasitic on various fresh-water fishes, as carp, sticklebacks, trout, pike (E'sox luciuss), greyling (Thymallus vulgaris), and others. The species appears to be generally distributed throughout the British Islands. Some years ago it was very common on greyling in the upper waters of the Clyde, but after a few days' heavy rain which flooded the river the Argulus had all disappeared. This species has also been obtained on a fish captured in the Faroe Channel by G. H. Fowler. The specimen is now in the British Museum, and we are indebted to Dr. W. 'T'. Calman for drawing our attention to it and for the loan of it for examination.

There appears to be some uncertainty as to the relationship between the Argulidx and the species usually recognized as. Copepoda. Dr. Baird includes the Family Argulidæ in. the same Tribe-Peltocephala-with the Caligidæ, the Pandaridæ, and the Cecropidæ.* In 1866 Gerstaecker, revising his previous classification, replaces the Argulidx under the Branchiopoda. $\dagger$ Claus in 1875 proposed making the Argulidæ a second suborder of the Branchiura, under the Order Copepoda. $\neq$ On the other hand, the Rev. T. R. R. Stebbing, in 'A History of Crustacea,' places the carp-lice (Argulus: in the suborder Branchiura of the Order Branchiopoda, and

* 'Entomostraca,' p. 15.

$\dagger C f$. Bronn's 'Klassen und Ordnungen des Thierreichs,' vol. v, p. 16.

‡ "Über die Entwickelung, Organisation, und Systematische Stellung der Arguliden," 'Zeitsch. f. wissensch. Zool.,' vol. xxv, pp. 217-284, pls. xiv-xviii. 
not with the Copepoda.* Dr. Bassett-Smith, in his 'Systematic description of the parasitic Copepoda found on Fishes,' also excludes the Family Argulidæ from the Order Copepoda.t And lastly, in the first of an important series of 'Memoirs on North American parasitic Copepods,' by Charles Branch Wilson, that author makes the Branchiura a suborder of the Copepoda, with Argulidæ as the only Family.f

'T'here is doubtless a close relationship between the Argulidæ and the other parasitic groups enumerated in this volume; but apparently, as indicated, there is also a considerable divergence of opinion as to whether Argulus and its allies should be recognized as a suborder of the Copepoda. We have, however, had few opportunities for studying these interesting forms, as there is only a single British species known to us, and therefore we do not propose to enter further into a discussion of this question.

\section{Tripaphylus musteli (P. J. van Beneden). pp. 160- 161.}

\section{Amended description of male.}

Our description of the male of this copepod parasite was copied, to some extent, from van Beneden's work, as we had not then seen the male ourselves. We discovered a male attached to a female after the description was in type, and some changes appear to be necessary to bring the description more in line with the views now generally accepted regarding the names of the appendages, but it was too late to do this in the proper place. This description, taken from our own specimen, should read as follows:-

Male.-The male of this species has the body divided into two unequal portions; the anterior portion is large and carries the whole of the appendages-viz. one pair of antennules, one pair of antennæ, one pair of mandibles, one pair of maxillæ, and two pairs of maxillipeds; the posterior portion is much more narrow and rounded and is terminated by short stout furca. 'The antennules, antennæ, mandibles, and maxillæ are

* 'A History of Crustacea : Recent Malacostraca.' The International Scientific Series, vol. lxxiv (1893), pp. 10 and 49.

+ "A systematic description of the Copepoda found on fishes, with an enumeration of the known species," 'Proc. Zool. Soc. Lond.,' April, 1899.

‡ "North American Parasitic Copepods of the Family Argulidæ," "Proc. United States National Museum,' vol. xxv (1902), pp. 635-742, pls. viiixxvii. 
somewhat rudimentary. The two pairs of maxillipeds are comparatively well developed and form prehensile appendages similar to those found in the males of many of the sedentary female fish-parasites. The appendages described as feet by van Beneden, and also in the second paragraph on p. 161, are the first and second maxillipeds. No appendages corresponding to feet in the more highly organized parasitic Copepoda appear to be present.

List of the Fishes on which the Parasitic Copepoda DESCRIBED IN I'HIS VOLUME WERE OB'I'AINED.

Acipenser sturio Linn. Agonus cataphractus Linn. Alopias vulpes (Gmelin) $\cdots$ Anarrhichas lupus Linn. . Bothus maximus (Linn.) . Bothus rhombus (Linn.) . Brosmius brosme $\mathrm{Cuv}$. Callionymus lyra Linn. Callionymus maculatus Linn. Cantharus lineatus (Mont.) Carcharias glaucus (Linn.) Clupea alosa Linn. . . Clupea finta Cuv.

Clupea sprattus Limn.

Conger niger Risso .

Corregonus pollan Thomps.

Crenilabrus melops (Linn.)

Ctenolabrus rupestris (Linn.)

Cyclopterus lumpus Limn. .

Cyprinus carpio Linn.

Drepanopsetta platessoides

$(\mathrm{Fabr}$.

Engraulis encrasicholus Linn. Esox lucius Linn.

Gadus æglefinus Limn. Gadus callarius Linn.

Gadus luscus Linn

Gadus merlangus Linn.

Gadus minutus Linn. .

Gadus pollachius Linn.
- Sturgeon.

- Pogge.

- 'I'hrasher Shark.

- Cat-fish; Wolf-fish. 'I'urbot.

Brill.

Torsk or 'Tusk.

Gemmeous Dragonet. Spotted Dragonet.

Black Bream.

Blue Shark.

Allis Shad.

'Twaite Shad.

Sprat.

Conger.

Pollan.

Connor ; Goldsinny.

Jago's Goldsinny.

Lumpsucker.

Carp.

Long Rough Dab.

Anchovy.

Fresh-water Pike.

Haddock.

Codfish.

- Bib; Whiting Pout.

- Whiting.

- Poor Cod.

- Pollack. 
Gadus virens $\operatorname{Linn}$.

Galeorhinus galeus (Linn.)

(Galeus canis Bonap.)

Gasterosteus aculeatus Linn.

Gastræa spinachia (Linn.)

Gobius minutus Gmelin .

Hippoglossus vulgaris Flem.

Labrax lupus Cuv. \& Val. .

Labrus bergylta Ascan.

Labrus mixtus Linn. .

Lamna cornubica $C u v$.

Lampris pelagicus (Gun.) .

Leuciscus rutilus (Linn.) .

Lophius piscatorius Linn. .

Luvarus imperialis Rafin .

Macrurus cœlorhynchus Risso

Merluccius vulgaris (Cuv.)

Molva vulgaris (Flem.)

Mugil chelo Cuv.

Mullus barbatus (Linn.)

Mustellus vulgaris Müll.\& Henle

Onos cimbrius (Linn.)

Onos mustelus (Linn.)

Onos tricirratus (Brïn.)

Orcynus thynnus (Linn.)

Orthagoriscus mola (Linn.)

Pagellus centrodontus (De la Sea-bream. Roche)

Perca fluviatilis Linn.

Pleuronectes cynoglossus Linn. .

Pleurnoectes flesus Linn.

Pleuronectes limanda Linn.

Pleuronectes microcephalus Don.

Pleuronectes platessa Linn.

Pholis gunnellus (Linn.) .

Phycis blennoides (Brïn.)

Raia batis Linn.

Raia circularis Couch

Raia clavata Linn. .

Raia fullonica Linn. .

Raia maculata Mont. .

Raia oxyrhynchus Linn.

Rhina squatina (Linn.)

Salmo fario Linn.

Salmo salar Linn.
Coalfish.

Tope or 'Toper.

Three-spined Stickleback.

Fifteen-spined Stickleback.

- Speckled Goby.

- Halibut.

- Basse.

- Ballan Wrasse ; Bergylt.

- Striped Wrasse.

Porbeagle.

- Opah; King-fish.

- Roach.

- Angler or Angler-fish.

Grenadier-fish.

- Hake.

- Ling.

- Grey Mullet.

Surmullet; Red Mullet.

Smooth-hound.

Four-bearded Rockling.

Five-bearded Rockling.

- 'I'hree-bearded Rockling.

- Tunny.

- Short Sunfish.

- Perch.

Pole-dab; Witch-sole.

Flounder.

Dab.

Lemon-sole.

- Plaice.

- Gunnel; Butter-fish.

- Greater Fork-beard.

- Grey or Blue Skate.

- Sandy Ray.

- Thornback Skate.

- Shagreen Ray.

- Homelyn Ray.

- Long-nosed Skate.

- Angel-fish.

- Trout.

- Salmon. 
Salmo trutta Linn. . . . . Salmon trout.

Sciæna umbra (Lacép.) • . Maigre.

Scomber scombrus Linn. . . Mackerel.

Scylliorhinus canicula (Linn.) . Rough-hound; Lesser Spotted Dog-fish.

Scyllium catulus Cuv. . . Nurse or Nurse-hound.

Scymnus borealis Flem. . Greenland Shark.

Sebastes norvegicus (Ascan.) Bergylt; Norway Haddock. Solea vulgaris Quensel . . Black Sole.

Squalus acanthias Linn. . . . Spur-Dog; Piked Dog-

Thymallus vulgaris Nilss. . Greyling.

Trigla cuculus Linn. . ～. ～. Red Gurnard. (Trigla pini Bloch.)

Trigla gurnardus Linn. . Grey Gurnard.

Trigla lineata Gmelin . . Streaked Gurnard.

Trigla lucerna Linn. . . . . Sapphirine Gurnard; Yel-

Trigla lyra Linn. . . . Piper; Crowner.

Trygon pastinaca (Linn.) . . Sting-ray.

Xiphias gladius Linn. . . Sword-fish.

Zeugopterus punctatus (Blainv.) Müller's 'Topknot.

Zeus faber Linn.

Dory; John Dory; Doree.

Note. -The scientific names of the fishes in this list are, with a few exceptions, from 'A History of Scandinavian Fishes,' by B. Fries, C. U. Ekström, and C. Sundevall, 2nd edit., revised by Prof. F. A. Smitt (1893-95). 


\section{LITERATURE}

CHIEFLY REFELRED TO IN THE PRECEDING PAGES.

1. 1794 Abildgaard, P. C. Beskrivelse over tvende nye Monoculi linn. (Caligus crassus et oblongus.)Skrift. Naturhist. Selsk. Kjöbenhavn, III, 2, pp. $46-54$.

2. 1865 Agassiz, A. Sur un Pennella, parasite de l'Orthagoriscus mola. - Illustrated Catalogue of the Museum of Comparat. Zoology, Cambridge, p. 87.

3. 1909 Bainbridge, May E. (Hon. Mrs. Henn Collins). Notes on some parasitic Copepoda with a description of a new species of Chondracanthus (C. inflatus).-TTrans. Linn. Soc. London, Zool., Ser. 2, Vol. XI, part 3.

4. 1850 Baird, $D r . W$. 'The Natural History of the British Entomostraca.-Ray Society. London.

5. 1783 Barbut, $J$. The genera Vermium exemplified by various specimens of the animals contained in the orders of the Intestina et Mollusca Linnæi. Drawn from Nature. London.

6. 1896 Bassett-Smith, Dr. P. W. Notes on the Parasitic Copepoda of fish obtained at Plymouth with descriptions of new species. - Ann. and Mag. Nat. Hist. (6), Vol. XVIII, pp. 8-16, with 4. plates.

7. 1896 idem. List of Parasitic Copepoda of fish obtained at Plymouth.-Journ. Mar. Biol. Assoc., N.S., Vol. IV, pp. 153-163.

8. $1899 \mathrm{idem}$. A Srstematic Description of Parasitic Copepoda found on fishes, with an enumeration of the known species.-Proc. Zool. Soc. London, 1899, Pt. II, pp. 438-507, with one plate.

9. 1765 Baster, Job. Opuscula subseciva, Vol. II, p. 138. Harlemi.

10. 1905 Baudouin, $M$. Les parasites de la Sardine.-Rev. Scient. Paris, No. 23, 10 Juin, pp. 715-722, with 4. text-figs. 
11. 1851 Beneden, P. J. van. Recherches sur quelques Crustacés inférieurs.-Ann. Scienc. Nat., 3 Sér. Zool., Vol. XVI, pp. 71-131, pls. 2-6.

12. 1851 idem. Note sur un Crustacé parasite nouveau, avec l'énumération des espèces de cette classe qu'on observe sur les poissons du littoral de Belgique.-Bull. Acad. Roy. de Belg., T. XVIII, pt. 1 , pp. 286-290 avec pl.

13. 1852 idem. Note sur un nouveau genre de Crustacé parasite de la famille des Peltocéphales.-Bull. Acad. Roy. de Belg., 'I. XIX, pt. 3, pp. 462-467, avec $\mathrm{pl}$.

13a. 1852 idem. Note sur quelques parasites d'un poisson rare sur nos côtes (le maigre d'Europe, Scizna aquila Cuv.).-Bull. Acad. Roy. de Belg., 'T. XIX, pt. 3, pp. 98-109 avec pl.

13b. 1853 idem. Note sur un nouvean genre de Crustacé parasite, Eudactylina (E. acuta).-Bull. Acad. Roy. de Belg., 'T. XX, pt. 1, pp. 235-239.

13c. 1853 idem. Notice sur un genre nouveau de la tribu des

Caligiens (genre Krö̈yeria van Ben..).-Bull. Acad.

Roy. de Belg., 'T. XX, pt. 1, pp. 23-30 avec pl.

14. 1854 idem. Notice sur un nouveau genre de Siphonostome (genre Congericola).-Bull. Acad. Roy. de Belg., 'I'. XXI, pt. 2, pp. 583-589.

14a. 1857 idem. Sur un nouveau Dinémoure provenant du

Scimnus glacialis.-Bull. Acad. Roy. de Belg., (2)

'I. I, pt. 1, pp. 226-235 avec pl.

15. $1861 \mathrm{idem}$. Recherches sur les Crustacés du littorale de Belgique. Mém. Acad. Roy. de Belg., T'. XXXIII, n. 3, 174 pp., 21 pls.

16. $1870 \mathrm{idem}$. Les poissons des côtes de Belgique, leurs parasites et leurs commensaux.-Mém. Acad. Roy. de Belg., 'T. XXXVIII, n. 4, 100 pp., 6 pls.

17. 1864 Bergsoe, V. Philichthys xiphix Stp., Monographisk Fremstittet.-Naturhist.'l'idkssrift, 3 Raek., 3 Bind, pp. 87-130, tab. 13, Kjobenhavn; (oppure Ann. Scienc. Natur., 5 sér. Zoologie, Vol. III, p. 213, pl. I, 1865).

18. 1898 Brian, $A$. Note préliminaire sur les Copépodes parasites des poissons.-Bull. Instit Oceanogr., No. 110 , p. 19, with text-figs. (Records 'Pennella filosa' from Sunfish, \&c.). 
19. 1899 BrIAN, A. (contd.). Di alcuni Crostacei parassiti dei pesci dell'Isola d'Elba.-Atti Soc. Lig. Sc. Nat. e Geogr., Vol. X, pp. 1-10, with textfigs.

20. 1899 idem. Diphyllogaster thompsoni n. gen. e sp. di Caligidæ della Dicerolatis giornæ Günth.-Atti Soc. Lig. Sc. Nat. e Geogr., Vol. X, pp. 1-11, con. tav.

21. 1906 idem. Copepodi Parassiti dei Pesci d'Italia. Con 21 Tavole. Genova.

21a. 1908 idem. Note préliminaire sur les Copépodes parasites des poissons provenant des Campagnes Scientifiques de S.A.S. le Prince Albert Ier de Monaco ou déposés dans les collections du Musée Océanographique.-Bull. Instit. Oceanogr. No. 110.

22. 1816 Blainville, H. M. D. de. Prodromus d'une Nouvelle Classification du Règne Animal. Paris.

23. 1816 idem. Article Lernæa in Dict. d. Scienc. Natur., Vol. XXVI, p. 112, ff., 1816 (e 1823).

24. 1822 idem. Mémoires sur les Lernées.-Journ. de Physique, 'I. 95, pp. 372-380, et pp. 437-447, avec $1 \mathrm{pl}$.

25. 1883 Brady, G. S. Report on the Copepoda (including Copepoda parasitic on fishes).-Voyage of H.M.S. 'Challenger,' Zool., Vol. VII, Part XXIII.

26, 27. 1833 Burmeister, $H$. Beschreibung einiger neuen oder wenig bekannten Schmarotzerkrebse, nebst allgemeinen Betrachtungen über die Gruppe, welcher sie angehören.-Nova Acta Acad. Leopold.-Carolin., XVII, 1, pp. 269-336, mit 3 Taf.

28. 1870 idem. Bomolochus belones, occurrence in Mediterranean and German Sea.-Hartmann's Archiv. Anat. Physiol. (1870), pp. 116-163.

29. 1892 Canu, E. Les Copépodes du Boulonnais, parasites des poissons. Annales de la Statione Aquicola de Boulogne-sur-mer (1892).

29a. 1884 Carus, J. V. Prodromus faunæ mediterraneæ. Pars I, pp. 345-378. Stuttgart.

30. 1858 Claus, C. Ueber den Bau und die Entwickelungsgeschichte parasitischer Crustaceen, pp. 1-34, 2 plates. Cassel. 
30a. 1860 Claus, C. (contd.). Zur Morphologie der Copepoden. 1. Eine Hemmungsbildung von Cyclops. 2. Ueber den Bau von Nicothoë. 3. Ueber die Leibesgliederung und die Mundwerkzeuge der Schmarotzerkrebse.-Würzb. Naturw. Zeitschr. Bd.I, pp. 20-36, 'l'af. 1.

31. 1861 idem. Ueber die Familie der Lernäen: Lernæocera gobina.-Würzb. Naturw. Zeitschr., Bd. II, pp. 10-22, 'Taf. 1.

32. 1861. idem. Ueber den Ban und die Entwickelung von Achteres percarum. Zeitschr. f. wiss. Zool., Bd. XI, pp. 287-308, Taf. 23 u. 24.

33. 1864 idem. Beiträge zur Kenntniss der Schmalotzerkrebse.-Zeitschr. f. wiss. Zool., Bd. XIV,pp. 365382, '1'. 33-36.

34. 1868 idem. Beobachtungen über Lernæocera, Peniculus, und Lernxa. Ein Beitrag zur Naturgeschichte der Ielnæen, mit 4 'Taf.-Schriften der Gesellschaft zu. Beförderung der gesammten Naturwiss. zu Marburg, 2 Supplement-Heft.

35. 1875 idem. Neue.Beiträge zur Kenntniss parasitischer Copepoden nebst Bemerkungen über das System derselben.-Zeitschr. f. wiss. Zool., Bd. XX்V, 4. mit 3 'laf. Leipzig.

36. 1780 Cordiner, Rev. Charles. Lernæa salmonea Linn.Antiquities and Scenery of the North of Scotland, pp. 7-8, pl. VI, fig. 2.

36a. 1865 Cornalia, $E$. Sulla Lophoura edwardsii di Kölliker. Osservazioni zoologiche e anatomiche.Atti Soc. Ital. Sc. Nat., Vol. IX, pp. 1-10, tav. 1.

36b. 1912 Cuénot, M. L. Contributions à la faune du bassin d'Arcachon : description d'Aigulus arcassonensis, nov. sp.-Bull. de la Station Biol. d'Arcachon, 14c, pp. 117-127, pls. 1 \& 2. (Extrait.)

37. 1817 Cuvier, G. L. Règne Animal. Première edit. 'Tom. III, pp. 60-66. Paris.

38. 1829 iılem. Règne Animal. Nouvelle édit. Tom. IV, pp. 189-202. Paris.

39. 1838 Dana, J. D. (see Pickering and Dana).

40. 1852 idem. United States Exploring Expedition during the years 1838-1842, under the command of Charles Wilkes. U.S.N. XIII, Crustacea. (Atlas Crustacea, Philadelphia 1855.) 
41. 1811 De la Roche, F. Sur deux animaux vivants sur les branchies des poissons.-Nouv. Bull. Soc. Philomat., II, pp. 270-272.

42. 1833 Edwards, H. Milne. Mémoire sur l'organisation de la bouche chez les Crustacés suceurs.-Ann. Scienc. Natur, Vol. XXIX, pp. 78-86.

43. $1840 \mathrm{idem}$. Histoire naturelle des crustacés, comprenant. l'anatomie, la physiologie, et la classification de ces animaux. Paris.

44. 1763 Ellis, $J$. Philos. Trans., Vol. 53, p. 433.-Pennatula. filosa and sagitta.

45. 1909 Elwes, E. V. 'The Sunfish and its parasites.-Journ. T'orquay Nat. Hist. Soc., Vol. I, No. I, pp. 17-20.

46. 1906 Evans, W. Læmargus muricatus from a Sunfish.Ann. Scott. Nat. Hist. (Jany.). Zoological notes.

47. 1904 Gadd, Pehr. Parasit-Copepoder i Finland.-Acta. Soc. pro Fauna et Flora Fennica, XXVI, No. 8.

48. 1853-54 Gerstaecker, A. D. Ueber eine neue und eine weniger gekannte Siphonostomen-Gattung, und Beschreibung zweier neuer Siphonostomen-Gattungen.-Wiegmann's Archiv f. Naturg., XIX, 1, pp. 58-70, 'Taf. 3 u. 4 ; XX, pp. 185-195, Taf. 7.

49. 1870-71 idem. In Dr. H. G. Bronn's Klassen und Ordnungen des 'Thier-Reichs. V. Band, Gliederfüssler. Lieferung 11-16. Leipzig u. Heidelberg.

50. 1889 Giard, A. Sur l'association de Pennella orthagorisci, Percival Wright, et de Conchoderma virgatum. Spengl._Le Naturaliste, (2) III, No. 50, p. 82.

51. 1899 Giesbrecht, W. Die Asterocheriden des Golfes. von Neapel und der Angrenzenden Meeres.Abschnitte. (A.u.d. Tit. : Fauna und Flora des Golfes von Neapel, 25 Monogr.)

52. 1842. Goodsir, H. Note sur le développement des œufs du Caligus et sur les métamorphoses que ce Crustacé éprouve.-Ann. Scienc. Natur., ¿2 sér., Zool., Vol. XVIII, pp. 181-184.

53. 1827 Grant, R. E. On the structure and characters of Lenna elongata from the Arctic Seas.-Edinburgh Journ. of Science, VII, pp. 147-154.

54. 1828 idem. Froriep's Notizen, Vol. XIX, p. 18.

55. 1829-1843 Guérin-Méneville, F. $E$. Iconographie du Règne animal. Crustacés. (Text, 1844.) 
56. 1879 Heider, C. Die Gattung Lernanthropus.-Arbeit. Zool. Instit. Wien. u. Triest., 'T. II, Hft. 3, pp. 269368, mit 5 Taf._Auch separ.; Wien, Holder, 1879.

57. 1904 Hofer, B. Handbuch der Fischkrankheiten.Verlag der allg. Fischerei-Zeitung. München.

58. 1865 Heller, $C$. Crustaceen der Novara-Expedition.

59. 1879 Hesse, E. Description des Crustacés rares ou nouveaux des côtes de Fr.nnce.-Ann. Scienc. Nat. 6 sér., Zool., Vol. VIII, art. 29.

60. 1884 idem. Crustacés rares ou nouveaux des côtes de France.-Ann. Scienc. Nat., 6 sér., Zool., Vol. XVI, art. 34, pp. 1-18, pls. 12-14.

61. 1783 Hermann, $J$. Helminthologische Bemerkungen.Naturforscher, n. 19.

61a. 1857 Hœven, J. van der. Note sur les genres Cecrops et Lemargus.-Mémoires d'Éntomol. de la Soc. Entom. des Pays-bas, I, pp. 67-87.

62. 1799 Holten, H. S. Acta Danica, Vol. V.

63. 1802 idem. Lernxa merlucii og Exocoti, to nye Arter. -Skrift. Naturhist. Selsk. Kjöbenhavn, V, 2, pp. 135-137.

63a. 1897 Horst, R. Philorthagoriscus serratus Kr. (Dinematura serrata Kr.) With 1 pl. Notes Leyden Mus., Vol. 19, N. $\frac{1}{2}$. Note XIV, pp. 137-144.

64. 1824 Johnston, $G$. Notice respecting the genus Caligus of Leach.-Edinburgh Philosoph. Journ. X, pp. 292-294.

65. 1835 idem. Lernæa uncinuta.-Loudon's Mag. of Nat. Hist., VIII, pp. 565-566.

66. 1835 idem. Pandarusalatus and lamnæ. Loc. cit. VIII, pp. 202-205.

67. 1836 idem. Chondracanthus lophii, nov. spec. Loc. cit. IX, pp. 81-83.

68. 1892. Kane, W. V. de Vismes. On a new species of Lernæopoda (bidiscalis) from the West Coast of Ireland, and Polperro, Cornwall.-With 2 pls. Proc. Roy. Irish Acad. (3) Vol. 2, n. 2, pp. 203211. A bstr.; Journ. Roy. Micr. Soc. London, 1892, Pt. 4, p. 480.

68a. 1853 Kölliker, $A$. Bericht über einige im Herbst 1852 in Messina angestellte vergleichend anatonische Untersuchnngen. Gatt. Lophoura.-Zeitschr. f. Wiss. Zool. IV, p. 359. 
69. 1835 Kollar, $V$. Beiträge zur Kenntniss lernæenartigen Crustaceen. Annal. des Wiener Museums für Naturgeschichte, I, 1, pp. 72-92, mit 2 'I'af.

69a. 1877 Koren, $J$, and Danielssen, $D$. C. En ny art af slaegten Pennella.-Faun. litt. Norweg. $3 \mathrm{Hft}$, pp. 157-163.

70. 1837-38 Kröyer, $H$. Om Snyltekrebsene, isaer med Hensyn til den dansk Fauna.-Naturhistorisk Tidsskrift, Vol. I. pp. 172-208, pp. 252-304, pp. 476-505, pp. 605-628. tab. 2-3 u. 5-6-II. pp. 8-52, pp. 131-157, tab 1 u. 3. Kjöbenhavn.

71. $1863 \mathrm{idem}$. Bidrag til Kundskab om Snyltekrebsene.Naturhistorisk Tidsskrift, 3 die. Raekke, II Bind, pp. 75-426, tab. 1-18.- - separat; Kjöbenhavn.

71a. 1877 Kurz, W. Studien über die Familie der Lernæopodiden.-Zeitschr. f. wiss. Zool. Bd. XXIX.

72. 1815-22 Lamarck, G. B. P. de. Histoire naturelle des Animaux sans Vertèbres, Vol. V. (1818.) Seven species of copepod parasites described.

73. 1814 Leach, W. LE. Crustaceology. (In) Edinburgh Encyclopedia.

74. 1816 idem. Supplement.-Annulosa. loc. cit.

75. 1819 idem. Article Entomostraca in Dict.d. Scienc. Natur. 76. 1746 Linnæus, C. Fauna Suecica. 1st Edition. Lugduni Batavorum.

77. 1761 idem. loc. cit. 2nd Edition. Stockholmiæ.

78. 1766, 67, 68 idem. Systema Naturæ. 12th Edition.

79. 1899 Lönnberg, $E$. Bidrag til Kännedomen om fritt lefvande Caligider.-Verh. Biol. Ver. Stockholm, Bd. I, pp. 148-158.

79a. 1860 Lubbock, $J$. On some oceanic Entomostraca collected by Capt. 'Toynbee.-'T'rans. Linn. Soc. London, XXIII, pp. 173-192, pl. 29. (Describes Baculus elongatus recognized by Mrazek 35 years later to be a larval Penuella.)

80. 1890 Malard, A.E. Catalogue des Poissons (with their parasites).-Bull. Soc. Philomathique, Paris, $8^{\mathrm{e}}$ sér. Vol. 2, No. 2.

81. 1835-39 Mayer, A. F.J.C. Analekton für vergleichenden Anatomie. Bonn.

82. 1863 M'Intosh, $W . C$. Notes on the food and parasites of the Salmo salar Linn. of the Tay.-Journ. Limn. Soc. London, Zool., Vol. VII, pp. 145-154. 
83. 1880 Miers, E. J. On a small collection of Crustacea madeby Edmund Whymper, Esq., chiefly in the $\mathrm{N}$. Greenland seas, \&c.-Journ. Linn. Soc. London, Zool., Vol. XV, pp. 59-73 (records Caligus curtus, Dinematura ferox, and Lernæopoda elongata).

84. 1895 Mrazek, Al. Ueber Baculus Lubb. und Hessella Brady, ein Beitrag zur Anatomie der Lernæiden. Mit 2 Taf. und 2 Holzchn.-Sitzgsber. K. Böhm. Ges. Wiss., math.-nat. Cl. XLIV. Ausz. vom. Verf. Zool. Centrabl. 3 Ihg. n. 7, pp. 237-238.

85. 1777 Müller, O. F. Zoologia Danica.

86. 1785 idem. Entomostraca, seu Insecta testacea quæ in aquis Dania et Norvegia reperit, descripsit, et. iconibus illustravit. Lipsia et Hafnia (Leipzig and Copenhagen).

87. 1903 Norman, A. M. New generic names for some Entomostraca and Cirripedia.--Ann. and Mag. Nat. Hist., (7) XI, pp. 367-369.

87a. 1910 Norman, A. M., and Brady, G. S. The Crustacea of Northumberland and Durham.-Trans. Nat. Hist. Soc. Northumberland, Durham, and Newcastle-upon-Tyne. N.S., Vol. III, part 2.

88. 1906 Norman, A. M., and Scott, T. Crustacea of Devon and Cornwall. London.

89. 1832 Nordmann, A. Mikrographische Beiträge zur Naturgeschichte der wirbellosen 'Thiere, 2 Hefte. Berlin.

90. 1864 idem. Nene Beiträge zur Kenntuiss parasitisclıer. Copepoden. Erster Beitrag.-Bull. de la Soc. des Natur. de Muscou, XXXVII, 2, pp. 461-520, Taf. $5-8$.

91. 1815 Oken, L. Lehrbuch der Naturgeschichte. Th. III, p. 184, ff., und p. 357, if. (Schisturus replaced by Clavella as the fir'st name was occupied by Rudolphe in 1809 for a genus of Vermes).

92. 1868 Olsson, P. Prodromus faunæ Copepodorum parasitantium Scandinaviæ. Lunds Univ. Arsskrift., 'Tom. V.

93. 1828 Otto, A. W. Beschreibung eiliger neuen, in den jahren 1818 und 1819 im mittelländischen Meere gefundener Crustaceen.-Nova Acta Acad. Leopold. Carolin., Vol. XIV, Pt. 1, pp. 351-35t, Mit drei Kupfertafelen. 
94. 1861 Pagenstecher, Dr. A. H. Thersites gasterostei, eine Gattung parasitischer Crustaceen.-Weigmann's Archiv. f. Naturgesch. XXVII, 1, pp. 118-126, Taf. 6.

95. 1905 Pearson, $J$. A list of the Marine Copepoda of Ireland. I, Littoral forms and Fish Parasites.Fish. Ireland Sci. Invest. 1904, iii.

96. 1838 Pickering, Ch., and Dana, J. D. Description of a species of Caligus (C.americanus).-Dilliman's Americ. Journ. of Science, XXXIV, pp. 225-266, pl. 3-5. Read before the Yale Nat. Hist. Soc., Feb. 20, 1838.

97. 1902 Poche, F. R. Bemerkungen zu der Arbeit des Herrn Bassett-Smith 'A Systematic Description of Parasitic Copepoda found on Fishes, with an Enumeration of the known Species'-Zool. Anzeig., 26 Bd. n. 685, pp. 8-20.

97a. 1884 Rathbun, Rich. Annotated List of the described species of parasitic Copepoda (Siphonostoma) from American Waters contained in the United States National Museum.-Proc. U. S. National Museum, Vol. 7, pp. 483-492.

98. 1887 idem. Descriptions of (4) new species of parasitic Copepods belonging to the genera l'rebius, Perissopus, and Lernanthropus.-Proc. U. S. National Museum, Vol. 10, pp. 559-571.

99. 1887 idem. Descriptions of parasitic Copepoda belonging to the genera Pandarus and Chrondracanthus. With 7 plates.-Loc. cit.,.Vol. 9, pp. 310-324. Abstr. in Journ. Roy. Microsc. Soc. 1887, pt. 3, p. 395 (4 n. sp.).

99a. 1839 Rathke, H. Bemerkungen über den Bau des Dichelesthium sturionis und der Lernæopoda stellata.-Nova Acta Acad. Leopold.-Carolin., V.ol. XIX, 1, pp. 125-168, mit 1 plate.

100, 101. 1843 idem. Beitrag zur Fauna Norwegens.-Nova. Acta Acad. Leopold.-Carolin., Vol. XX, 1, pp. 1-264, mit 12 Taf.

TOL. I. 
101a.1829-31 Retzius, $A$. Beskrifning öfver en ny Skandinavisk Lernæa fran Nordsjön, kallad Lernæa Dalmanni.-Kongl. Vetensk. Akad. Handling, Stockholm, pp. 109-119, c. tab. oppure: Beschreibung einer neuen Scandinavischen Lerna'a aus dem Nordsee, Lernæa Dalmanni gennant. Froriep's Notizen, Bd. XXIX, p. 6, figs. 5-9, 1830. Idem in Isis, 1831, p. 1345, 'l'af. IX.

102. 1877 Richiardi, $S$. Descrizione di due specie nuove di Lernæenicus ( $L$. neglectus, $L$. vorax) con osserv. intorno a questo ed ai gen. Lernæocera Bl. e Lernxonema M. Edw.-Atti Soc. Tosc. Sc. Nat. Pisa, Vol. III, fasc. 1.

103. 1878 idem. Tripaphylus musteli.-Processi verbali, Soc. Tosc. Sc. Nat. Pisa, XX.

104. 1880 idem. Catalogo sistematico dei crostacei che vivona sul corpo degli animali aquatici.-Catalogo Sez. Ital. Esposiz. Internaz. di Pesca, Berlino, 1880-Firenze-anche in Pisa tip. Vannucchi 1880 (8 pp.). For Clavella canthari, \&c.

105. 1826 Risso, $A$. Histoire naturelle des productions de l'Europe meridionale, Vol. V, p. 175 Paris. Refers to Otto's Caligus minimus, \&c.

105a. 1886 Sars, G. O. The Norwegian North Atlantic Expedition 1876-1878, Zoology-Crustacea, Part II, p. 80. (Records Anchorella uncinata and Hæmobaphes cyclopterinus.)

106. 1850 Salter, James. Description of Lerneonema Bairdii. -Ann. and Mag. Nat. Hist., (2) VI, pp. 85-87, pl. vii B.

107. 1901 Scott, $A$. Some additions to the Fauna of Liverpool Bay.-Trans. Biol. Soc. of Liverpool, Vol. XV, pp. 342-353, with 2 pls.

108. 1901 idem. Lepeophtheirus and Lernæa.-Liverpool Marine Biology Committee Memoirs, No. VI, 54 pp., with 5 plates.

109. 1904 idem. Some parasites found on fishes in the Irish Sea.-Trans. Biol. Soc. Liverpool, Vol. XVIII, pp. 119-125.

110. 1906 idem. Faunistic Notes.-Loc. cit., Vol. XX, pp. 191-201, with pls. ii-vii. 
111. 1907 Scotr, A. (contd.). Faunistic Notes.-Loc. cit., Vol. XXI, pp. 191-198, with pls. i-v.

111a. 1893 Scott, T. Additions to the Fauna of the Firth of Forth. Part V.-11thAnnual Report Fishery Board for Scotland, Part III, p. 212, pl. V, figs. $1-13$.

111b. 1894 idem. Additions to the Fauna of the Firth of Forth. Part VI.-12th Annual Report loc. cit. p. 233.

111c. 1897 idem. The Marine Fishes and Invertebrates of Loch Fyne.-15th Annual Report loc. cit. p. 155. 111d. $1898 \mathrm{idem}$. On the distribution of the pelagic Invertebrate Fauna of the Firth of Forth and its vicinity during the seven years from 1889 to 1895, both inclusive.-16th Annual Report loc. cit. p. 177.

112. 1900 idem. Notes on some Crustacean Parasites of Fishes.-18th Annual Report loc. cit. pp. 144188 , pls. V-VIII.

113. 1901 idem. Notes on some Parasites of Fishes.-19th Annual Report loc. cit. pp. 120-151, pls. VIIVIII.

114. 1902 idem. Notes on some Parasites of Fishes.-20th Annual Report loc. cit. pp. 288-299, pls. XII, XIII.

115. 1904 idem. On some Parasites of Fishes new to the Scottish Marine Fauna.-22nd Annual Report loc. cit. pp. 275-278, pl. XVII.

116. 1905 idem. Observations on some Parasites of Fishes new or rare in Scottish Seas.-23rd Annual Report loc. cit.pp. 108-115, pls. V-VI.

117. 1907 idem. Some additional notes on Copepoda from the Scottish Seas.-25th Annual Report loc. cit. pp. 216-218, pl. XV.

118. 1909 idem. Some notes on Fish Parasites. -26th Annual Report loc. cit. pp. 73-77, pl. III.

119. 1900 idem. On Copepods living in the nostrils of Fishes. -Ann. Scott. Nat. Hist. pp. 153-155 (July 1900).

120. 1901 idem. Clavella labracis, van Ben., a Copepod new to Britain.-Ann. Scott. Nat. Hist. pp. 110-121 (April, 1901). 
121. 1883 Smith, S. I. Review of the marine Crustacea of Labrador.-Proc. U. S. National Museum, pp. 223-232.

121a. 1899 Stebbing, T. R. R. Genus Sphyrion Cuvier.Rep. Marine Biolog. Cape 'Iown, 1898, p. 897.

122. $1900 \mathrm{idem}$. South African Crustacea, Part I.-Cape of Good Hope Department of Agriculture, Marine Investigations in South Africa.-Records Sphyvion lærigatus, Guérin-Méneville.

123. 1900 idem. On Crustacea brought by Dr. Willey from the South Seas.-A. Willey's Zoological Results,

Pt. V (Cambridge Univ. Press), Dec. 1900.

124. 1905 South African Crustacea, Part iii.-Marine Investigations in South Africa, Vol. IV.

125. 1910 idem. General Catalogue of South African Crustacea. (Contains also descriptions of new species.) -Annals of the South African Museum, Vol. VI, Part IV.

126. 1862 Steenstrup, J. J. S. Philichthys xiphix, en ny snylter lins Svaerdfisken.-Overs. Kongel. Danske Vidensk. Selsk. Forhandl. 1861, pp. 295̄-305, pl. 2.

126a. 1869 idem. On Lesteiva, Silenium, og Pegesimallus, tre af Prof. H. Kroyer opstillede Slaegter af Snyltekrebs.-Overs. Kongel. Danske Vidensk. Selsk. Forhandl. 1869.

127. 1861 Steenstrup, J. J. S., and Lütken, C. Bidrag til Kundskab om det aabne Havs Synltekrebs og Lernæer, etc.-Kongel. Danske Vidensk. Selsk. Skrifter, 5te Raekke, naturh. og math. Afdeling, Bd. T. Kjöbenharn.

128. 1844 Thompson, WT. Report on the Fauna of Ireland, div. Invertebrata.- Report of the British Association for 1843 .

129. 1847 idem. Additions to the Fauna of Ireland. (Lepeophtheirus strömi, etc.).-Anm. and Mag. Nat. Hist., Ser. I, Tol. XX, p. 248.

130. 1856 idem. Natural History of Ireland, Vol. IV, p. 407. London.

131. 1885 Thomson, G. M. Parasitic Crustacea.-New Zealand Journ. of Science, Vol. 2, p. 455 ; New Crustacea, loc. cit. p. 576. 
132. 1889 Thomson, G. M. (contd.) Parasitic Copepoda of New Zealand, with descriptions of new species. -Trans. New Zealand Instit., Vol. 22 (N.S. Vol. 5), pp. 353-376 (13 n. sp.), with 5 plates.

133. 1890 idem. A new parasitic Copepod.-Trans. New Zealand Instit., Vol. 23 (N.s. Vol. 6), pp. 227229, with 1 plate.

134. 1889 Thompson, I. C. 'Third Report on the Copepoda of Liverpool Bay.-Proc. Biol. Soc. Liverpool, Vol. III, pp. 181-191, pl. viii.

135. 1893 idem. Revised Report on the Copepoda of Liverpool Bay.-Trans. Biol. Soc. Liverpool, Vol. VII, pp. 175-230, pls. xv-xxxv.

136. 1897 idem. Further Report upon the Free-Swimming Copepoda of the West Coast of Ireland.-I'rans. Biol. Soc. Liverpoo!, Vol. XI, pp. 127-131. Refers to the swimming habits of Caligus.

137. 1900 Thompson, I. C., and Scott, $A$. Some recent additions to the Copepoda of Liverpool Bay.'Trans. Biol. Soc. Liverpool, Vol. XIV, pp. 139144, pl. viii.

138. 1903 idem. Supplementary Report VII. On the Copepoda.-Report to the Government of Ceylon on the Pearl Oyster fisheries of the Gulf of Manaar, Part I, pp. 227-307, with 20 plates. Published by the Royal Society, London.

139. 1905 Turner, Sir $W$. On Pennella balænopteræ: a Crustacean, parasitic on a finner Whale Balænoptera musculus.-Trans. Roy. Soc. Edinburgh, Vol. XLI, Part II, No. 18, pp. 409-434, with 4 plates.

140. 1862 Turner, Sir W., and Wilson, H. S. Observations on Parasitic Crustacea Chondracanthus lophii and Lernæopoda dalmanni.-T'Trans. Roy. Soc. Edinburgh, Vol. XXIII, part I, pp. 67-87, pl. 4.

141. 1807 Turton, $W$. British Fauna, Vol. I.

141a. 1880 Valle, A. Della. Crostacei parassiti dei Pesci del mare Adriatico.-Boll. Soc. Adriat. Sc. Nat., Vol. VI, pp. 55-90.

142. 1877 Vogt, $C$. Recherches cotières faites à Roscoff; Crustacés parasites des Poissons. Avec 6 pls. Genève. H. Georg. 1877, p. 104-oppure: Arch. Zool. Expér. et Gén. VI, 1877, pp. 385-4.56. 
143. 1879 Vogt, $C$. (contd.). Crustacés parasites des Poissons. - Mémoires de l'Institut National Genevois, Vol. XIII. ('Two Memoirs-separate copies) pp. 1 104, 6 plates.

143a. 1902 Wilson, Ch. Branch. North American Parasitic Copepods of the Family Argulidæ, with a Bibliography of the Group and a Systematic Review of all the known Species.-Proc. U.S. National Museum, Vol. XXV, pp. 635-742, with plates VIII-XXVII.

143b. 1904 idem. Anew species of Argulus, with a more complete account of two species already described. -Proc. U. S. National Museum, Vol. XXVII, pp. 627-655.

144. 1905 iilem. New species of Parasitic Copepods from the Massachusetts Coast.-Proc. Biol. Soc. Washington, Vol. 18, pp. 127-131.

145. 1905 idem. North American Parasitic Copepods belonging to the Family Caligidæ. Part 1. The Caliginæ.-Proc. U. S. National Museum, Vol. XXVIII, pp. 479-672, with plates V-XXIX.

146. 1906 idem. Supplementary Report XXXIV. On some Parasitio Copepoda.- Report to the Government of Ceylon on the Pearl Oyster Fisheries of the Gulf of Manaar, Pt. V, pp. 189-210, with 5 plates. Published by the Royal Society, London.

147. 1907 idem. North American Parasitic Copepodsbelonging to the Family Caligidæ. Part 2, 'The Trebinæ and Euryphorinæ.-Proc.U.S. National Museum, Vol. XXXI, pp. 669-720, with plates XV-XX.

148. 1907 idem. North American Parasitic Copepods belonging to the Family Caligidæ. Parts 3 and 4, A Kevision of the Pandarinæ and the Cecropinæ.-Proc. U. S. National Museum, Vol. XXXIII, pp. 323-490, with plates XVII-XLIII.

148a. 1907 idem. Additional Notes on the development of the Argulidæ, with description of a new species.-Proc. U. S. National Museum, Vol. XXXII, pp. 411-424, with plates XXIX-XXXII.

149. 1908 idem. North American Parasitic Copepods: A list of those found upon the fishes of the Pacific. Coast, with descriptions of new genera and species.-Proc. U.S. National Museum, Vol.XXXV, pp. 431-481, with plates LXVI-LXXXIII. 
149a. 1911 Wilson, C. B. (contd.). North American Parasitic C'opepods belonging to the Family Ergasilidæ. -Proc. U.S. National Museum, Vol. 39, pp. 263-400, with plates 41-60.

149b. 1911 idem. North American Parasitic Copepods.Part 9. the Lernæopudæ. - Proc. U. S. National Museum, Vol. 39, pp. 189-226, with plates 29-36. 149c. 1911 idem. North American Parasitic Copepods.

Descriptions of new genera and species.-Proc. U. S. National Museum, Vol. 39, pp. 625-634, with plates $65-68$.

149d. 1912 idem. Descriptions of new species of Parasitic Copepods in the collections of the United States National Museum.-Proc.U.S.National Museum, Vol. 42, pp. 233-243, with plates 30-34.

149e. 1912 idem. Parasitic Copepods from Nanaimo, British Columbia, including eight species new to science. - Contributions to Canadian Biology being studies from the Marine Biological Stations of Canada 1906-1910, pp. 85-102, with plates III-IX.

150. 1870 Wright, Edw. Perceral. On a new species of the genus Pennella.-Ann. and Mag. Nat. Hist., Ser. 4, Vol. V, p. 45, pl. 1. 


\section{INDEX.}

\section{(Synonyms in italics.)}

A.

abbreviatus, Caligus

acanthii, Eudactylina

Achteres .

Achtheres

Actheres .

acuta, Eudactylina

rglifini, Caligus

alata, Clavella .

alata, Dinemoura

alatus, Pandarus

ambiguus, Hæmobaphoides

ambiguus, Hæmobaphus

ambiguus, Nogagus

ambiguus, Nogaus

Anchorella

angustulus, Nogagus

annulatus, Chondracanthus

Anops

Anthosoma

Argulus .

argulus, Argulus

argulus, Monoculus

Arnæus .

asellina, Lernæa

asellina, Lernentoma

asellinum, Medesicaste .

asellinus, Oralien

asterodermi, Lütkenia .

B.

bairdi, Lernæonema

balænopteræ, Penella

Basanistes

bicolor, Pandarus

bicuspidatus, Caligus

bidiscalis, Lernæopoda
PAGE

Binoculus

bispinosa, Brachiella

Bomolochus

boscii, Pandarus

Brachiella

Brachiella

brachyptera, Elytrophora

branchialis, Caligus

branchialis, Lernæa

brevicaudatus, Caligus .

brevicollis, Anchorella .

brevicollis, Clavella

brevipedes, Caligus

brevipedes, Pseudocaligus

C.

213

95

169

168

108

227

227

227

83

184

184

184

184

76

CALIGID赵

Caligoina

Caligus .

Caligus .

canthari, Anchorella

canthari, Clavella

canthari, Lerneomyzon

carpionis, Lerneopoda

caudatus, Trebius

Cecrops .

Cecropsina

centrodonti, Caligus

charon, Argulus

Charopinus

ChondRaCaNTHIDE

Chondracanthus

Chondracanthus .

clavatus, Chondracanthus

Clavella .

Clavella.

200
PAGE

227

211

36

95

203

187

83

142

56

220

220

61

61

44

43

44

79

224

224

224

199

81

97

75

188

166

- 167

183

175

213

$\cdot \quad \cdot 112$

cluthæ, Clavella $\quad$. 117 
cluthæ, Hatschekia

cluthæ, Lernæopoda

coleoptrata, Dinematura

coleoptratus, Echthrogaleus

Congericola

cornigera, Hatschekia

cornuta, Anops .

cornuta, Entomoda

cornuta, Lernæa

cornuta, Lernentoma

cornuta, Phyllophora

cornutus, Chondracanthus

cornutus, Phyllophorus .

cornutus, Phyllothreus

crassum, Anthosoma .

crassus, Caligus .

curtus, Caligus .

Cyclopoida

cyclopterina, Hæmobaphes

cyclopterina, Lernæa .

cyclopterina, Lernæocera

Cycnus

cyprinacea, Lernæa

cyprinacea, Lernæocera

cyprinacea, Lerneocera .

D.

dalmanni, Charopinus .

dalmanni, Lernæa .

daimanni, Lernæopoda .

dalmanni, Lerneopoda

delarochianus, Chondracanthus

Demoleus

depressus, Chondracanthus

diaphanus, Caligus

diaphanus, Caligus

Dichelestiidæ

Dichelestium

Dinematura

Dinemoura

dubia, Clavella .

dubius, Charopinus

E.

Echthrogaleus .

edwardsi, Lophoura

edwardsi, Lophura

117

198

89

89

124

118

168

168

168

168

92

168

92

92

108

108

45

33

147

147

147

124

154

154

154

- 189

189

189

189

177

79

172

60

45

105

105

85, 103

85

217

190

.

PAGE 
Hæmobaphoides

Hatschekia

hippoglossi, Caligus

hippoglossi, Clavella

hippoglossi, Hatschekia

hippoglossi, Lepeophtheirus

hypocephalus, Stylophorus

I.

imbricatus, Caligus

impudica, Brachiella

impudica, Thysanote

inflatus, Chondracanthus

inominatus, Lepeophtheirus

insidiosa, Brachiella

insolens, Eudactylina .

isonyx, Caligus .

K.

Kroyeria

kröyeri, Lernanthropus

L.

labracis, Caligus

labracis, Clavella

labracis, Hatschekia

Læmargus

lævirajæ, Chondracanthus

lamnæ, Dinemoura

lamnx, Pandarus

lampri, ? Lernæopoda .

latreillii, Cecrops

latus, Nogagus

Lepeophtheirus

Lernæa .

Lernæa .

Lernæenicus

LERNAIDE

Lernæocera

LERNAOIDEA .

Lernæopoda

LERNAOPODIDE .

Lernanthropus .

Lernentoma

Lerneocera

Lerneomyzon

Lerneonema

L.

PAGE

148

112

67

112

112

67

189

108

187

187

169

73

206

135

60

120

. 110 


nodosa, Lernentoma
nodosus, Chondracanthus
Nogagus .
Nogaus .
nordmanni, Caligus .
nordmanni, Lepeophtheirus
O.
oblongum, Dichelestium
oblongus, Caligus
obscurus, Caligus
obscurus, Lepeophtheirus
obscurus, Lepeophtheirus
obscurus, Lepeophtheirus
onosi, Bomolochus .
Oralien .
ornatus, Chondracanthus
orthagorisci, Pennella .
Orthagoriscicola
ovalis, Anchorella
ovalis, Brachiella
Ozolus .

P.

pagelli, Anchorella

pallida, Congericola

pallidus, Cycnus

Pandarus

paradoxa, Anchorella' .

paradoxa, Clavella

paradoxus, Caligus

paradoxus, Demoleus .

parkeri, Brachiella

pastinaca, Brachiella

pastinacæ, Brachiella

pectoralis, Caligus

pectoralis, Lepeophtheirus

pectoralis, Lernæa

pelamydis, Caligus

Pennela

Pennella

percarum, Achteres

percarum, Achtheres

percarum, Actheres

Рhilichthyid

Philichthys

Philorthragoriscus
PAGE

176

176

77

77

66

66

106

106

70

70

67

69

39

183

182

150

100

210

210

227

224

124.

124

94

222

222

79

79

212

211

212

64

64

64

57

151

149

193

193

193

137

138

103
Phyllophora

Phyllothreus . . $\quad$. 92

pollachii, Lepeophtheirus $\quad$ 73

pollachius, Lepeophtheirus 73

producta, Dinematura . $\quad$. 86

producta, Dinemoura . $\quad$. 86

productus, Caligus . 86

productus, Nogagus . 86

Pseudocaligus . • . 61

pygmæa, Hatschekia 119

Q.

quadrata, Anchorella . . 223

quadrata, Clavella . . 223

R.

ramosus, Charopinus

191

rapax, Caligus . . . 48

Rebelula . $\quad$. 162

rhombi, Lepeophtheirus . $\quad 69$

rostrata, Brachiella . . 205

rugosa, Anchorella . . 216

rugosa, Clavella $\quad$. 216

S.

salmonea, Basenistes . 199

salmonea, Entomoda . 199

salmonea, Lernæa . 199

salmonea, Lernæopoda . $\quad 199$

salmonea, Lerneopoda 199

salmonis, Caligus . . 71

salmonis, Lepeophtheirus $\quad$. 71

Schisturus . $\quad . \quad 213$

Sciænophilus . $\quad$. 62

scomberi, Anchorella . $\quad 219$

scomberi, Caligus . $\quad$. 57

scombri, Anchorella . . 218

scombri, Clavella . $\quad 218$

serrata, Dinematura . 104

serratus, Philorthragoriscus . 104

similis, Eudactylina $\quad . \quad 130$

similis, Lernæopoda . 202

smithii, Anthosoma . 108

soleæ, Bomolochus . 36

soleæ, Chondracanthus $\quad 170$

Sphyrion . . . 164

spratta, Lernæa . . 156 


\begin{tabular}{|c|c|c|c|c|c|}
\hline & & $P A G E$ & & & PAGE \\
\hline spratta, Lernæenicus & - & . 156 & triglæ, Chondracanthus & & . 184 \\
\hline spratta, Lernxonema & - & . 156 & triglæ, Lernentoma & . & . 184 \\
\hline sprattæ, Lernæenicus & - & . 156 & triglarum, Medesicaste & . & . 185 \\
\hline stellata, Anchorella & - & . 220 & Tripaphylus & . & . 159 \\
\hline stellata, Clavella & . & . 220 & tuberculatus, Chondraca & anthus & . 177 \\
\hline stromi, Lepeophtheirus & . & 71 & & & \\
\hline stromii, Lepeophtheirus & . & . 71 & U. & & \\
\hline sturionis, Caligus & . & 74 & uncinata, Anchorella & . & - 214 \\
\hline sturionis, Dichelestium & . & . 106 & uncinata, Clavella & . & . 214 \\
\hline sturionis, Lepeophthei & rus & 74 & uncinata, Lernæa & . & . 214 \\
\hline Stylophorus & . & . 189 & uncinatum, Lerneomyzo & & $\because \quad 214$ \\
\hline T. & & & uncinatus, Schisturus & . & \\
\hline tenuis, Sciænophilus & - & 63 & W. & & \\
\hline tenuis, Scienophilus & . & 63 & williamsoni, Chondraca & enthus & . 176 \\
\hline Thersites & . & 41 & & & \\
\hline Thersitina & . & 41 & $\mathbf{X}$. & & \\
\hline thompsoni, Lepeophth & eirus & 69 & xiphiæ, Philichthys & - & - 138 \\
\hline thynni, Arnæus . & . & . 83 & & & \\
\hline thynni, Brachiella & . & . 204 & Z. & & \\
\hline Thysanote & . & . 187 & zei, Caligus & · & 54 \\
\hline Trebius . & . & - 81 & zei, Chondracanthus & . & . 177 \\
\hline triglæ, Anchorella & . & . 209 & zeugopteri, Bomolochu & & 40 \\
\hline triglæ, Brachiella & . & . 209 & zeus, Chondracanthus & . & . 177 \\
\hline
\end{tabular}

Errata.

p. 8, line 8 , for siphon read chitin filament.

,31, Genus 28, for cyclopterinus read cyclopterina.

" "Genus 33, for Trypaphylus read Tripaphylus.

„, 136, lines 13 and 14, for Eudactylin aacuta read Eudactylina acuta.

, 137, line 17, for Kroyeria cineata read Kroyeria lineata.

,199, Synonymy, line 6, for Basenistes read Basanistes. 
EXPLANATIONS OF PLATES A AND B. 


\section{Plate A.}

Figs.

1. Ventral surface of the pectoral fin of a flounder (Pleuronectes flesus Linn.), with thirty-two adult specimens of Lepeophtheirus pectoralis (Müller) adhering to it. $(\times 3$.

2. Head of a whiting (Gadus merlangus Linn.), with part of the operculum removed to shew an adult female Lernæa branchialis Linn. adhering to the gills. $(\times 2$.)

3. Part of the gills of a flounder (Pleuronectes flesus Linn.), shewing the "Cyclopoid" stage of Lernæa branchialis attached to the ends of the gill-filaments. $\left(\times 2 \frac{1}{2}\right.$. $)$

(Reproduced from photographs.) 


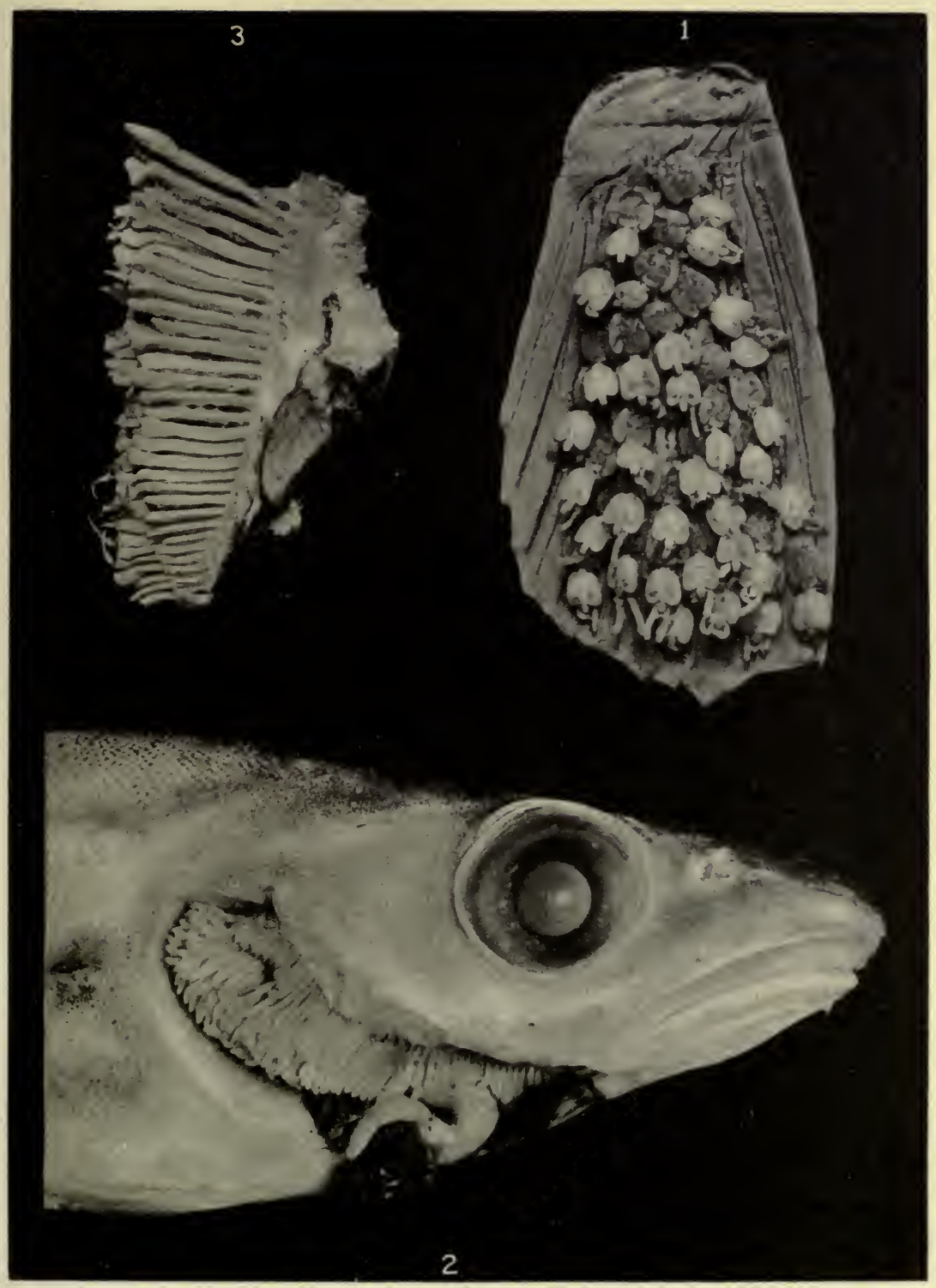





\section{Plate B.}

Figs.

1. Part of the gills of a dory (Zeus fuber Linn.), shewing an adult female Chondracanthus zei De la Roche in situ. $\left(\times 2 \frac{1}{2}\right.$. $)$

2. Adult female of Chondracanthus zei removed from its host. $(\times 2$.

3. Gill of a salmon (Salmo salar Linn.), shewing adult female specimens of Lernæopoda salmonea (Gisler) attached to the ends of the gill-filaments. 'The salmon was captured in the river Dee, near Aberdeen; the parasites adhered to the gill-filaments in considerable numbers, their white colour shewing distinctly against the red colour of the gills. (Nat. size.)

(Reproduced from photographs.) 
PLATE B.

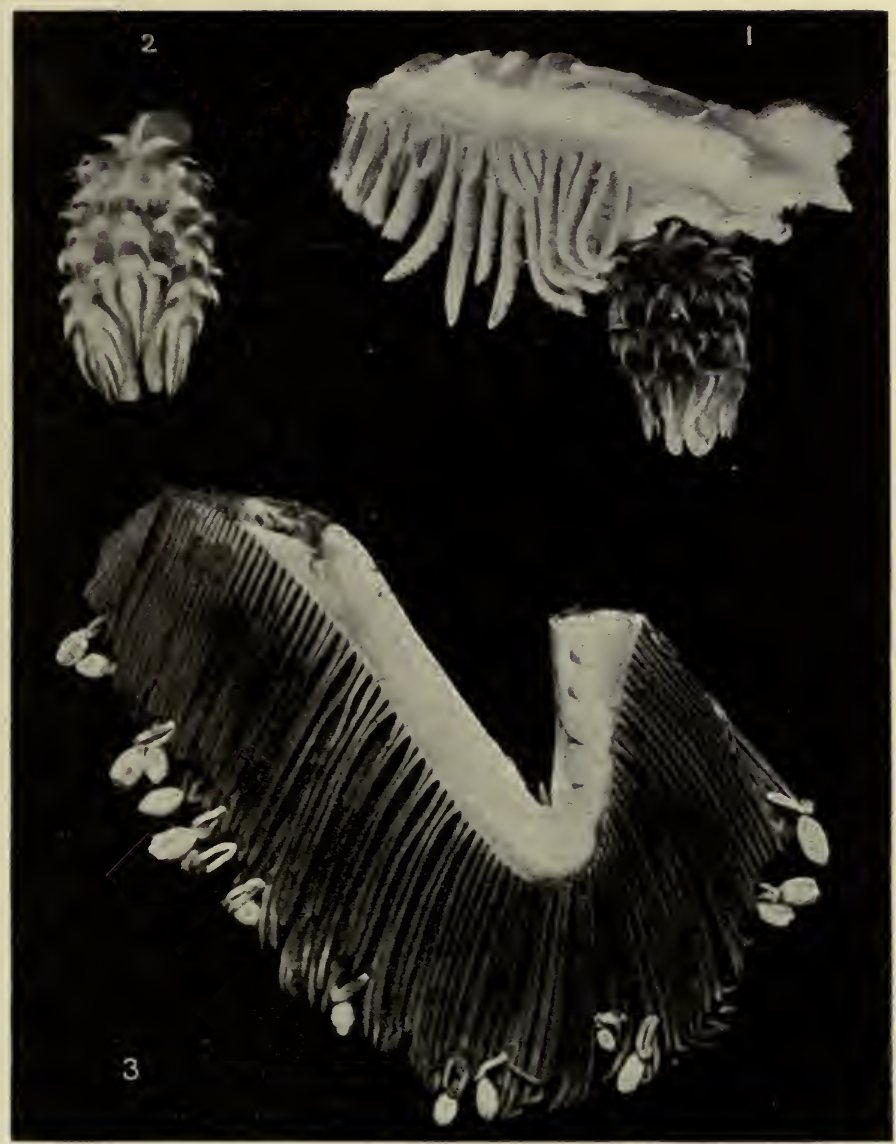





\title{
RAY SOCIETY
}

\author{
INSTITUTED 1844
}

FOR THE PUBLICATION OF WORKS ON

NATURAL HISTORY

ANNUAL SUBSCRIPTION ONE GUINEA

\section{LIST OF THE SOCIETY \\ FOR THE YEAR 1913}

CORRECTED TO 28Th FEBRUARY, 1913 



\section{OFFICERS AND COUNCIL.}

1912-13.

\section{身resident.}

The RT. Hon. LORD AVEBURY, P.C., D.C.L., LL.D., For.Sec.R.A., F.R.S., F.S.A., F.L.S., ETc.

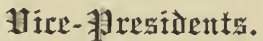

S. F. HARMER, M.A., Sc.D., F.R.S., F.Z.S.

A. D. MICHAEL, F.L.S., F.Z.S., F.R.M.S.

R. F. SCHARFF, Pн.D., B.Sc., F.L.S., F.Z.S.

\section{Coumcil.}

Robert AdKIN, F.E.S.

Rev. C. R. N. Burrows, F.E.S. T. A. Chapman, M.D., F.Z.S., F.E.S. Rev. Alfred Fuller, M.A., F.E.S. A. E. Gribs, F.L.S., F.Z.S., F.E.S. B. Daydon Jackson, Ph.D., F.L.S. Albert H. Jones, Treas.E.S.
G. B. LongstafF, M.D., F.E.S. J. W. S. МеiкцеJонn, M.D., F.L.S. JAMES MURraY, F.Z.S., F.R.M.S. A. W. Оке, B.A., LL.M., F.L.S., F.G.S. Charles Oldham, F.Z.S., M.B.O.U. C. D. SoAR, F.L.S., F.R.M.S. W. MARE WebB, F.L.S., F.R.M.S.

\section{Treasurer.}

F. DUCANE GODMAN, D.C.L., F.R.S., F.L.S., F.G.S., F.Z.S., F.E.S.

\section{Serretary.}

JOHN HOPKINSON, F.L.S., F.G.S., F.Z.S., Assoc.Inst.C.E.; 



\section{LIST OF THE RAY SOCIETY.}

Aberdeen University Library; King's College, Aberdeen. Adelaide Public Library; Adelaide, S. Australia.

Adkin, Robert, F.E.S. ; Wellfield, 4 Lingards Road, Lewisham, S.E.

Adlard, Robert Evan ; Bartholomew Close, E.C.

Advocates' Library; Edinburgh.

Albany Museum; Grahamstown, Cupe Colony, S. Africa.

American Museum of Natural History ; New York, U.S.A.

Armstrong College; Newcastle-upon-'Tyne.

Assheton, Richard, M.A., F.L.S., F.G.S., F.Z.S. ; Grantchester, Cambridge.

Athenæum Club; Pall Mall, S.W.

Australian Museum; Sydney, New South Wales.

Avebury, The Right Hon. Lord, P.C., D.C.L., LL.D., F.R.S., F.S.A., F.L.S., F.G.S., F.Z.S., F.E.S., President ; 15 Lombard Street, E.C.; 48 Grosienor Street, W.; and High Elms, Farnborough, Kent.

Baer, Joseph, \& Co. ; 6 Hochstrasse, Frunkfort, Germany. Bagshaw, Walter, F.R.M.S. ; Muorfield, Birkenshaw, Bradford. Barraud, Philip J., F.E.S.; Bushey Heath, Watford.

Barrow-in-Furness Public Library; Barrow-in-Furness.

Battersea Public Library; Lavender Hill, S.W.

Belfast Library; Donegal Square, Belfast.

Bentley, Richard, F.S.A., F.L.S., F.R.Met.Soc., F.R.G.S., F.S.S.; The Mere, Upton, Slough.

Berens, A. A., M.A.; 50 Eaton Square, S.W.

Bergens Museums Bibliotek; Bergen, Norway.

Berlin Royal Library; Berlin.

Berlin Royal Zoological Museum; Berlin.

Berne Natural History Museum ; Berne, Switzerland. 
Bestow, Charles Horton, F.R.M.S.; Melford House, 43 Upper Clapton Road, London, N.E.

Bethune-Baker, George T., F.L.S., F.E.S.; 19 Clarendon Road, Edgbaston, Birmingham.

Bibliothèque Nationale; Paris.

Binks, Mrs. I.; 9 Burton Street, Wakefield.

Birmingham Free Libraries; Birmingham.

Birmingham Natural History and Philosophical Society; Avebury House, 55 Newhall Street, Birmingham.

Bloomfield, The Rev. E. N., M.A., F.E.S.; Guestling Rectory, Hastings.

Board of Education, Secondary Branch; Science Library, South Kensington, S.W.

Bodleian Library ; Oxford.

Bootle Free Library; Oriel Road, Bootle, Liverpool.

Bostock, E. D., F.E.S. ; Holly House, Stone.

Boston Public Library; Boston, Mass., U.S.A.

Boston Society of Natural History; Berkeley Street, Boston, Mass., U.S.A.

Bowles, Edward Augustus, M.A., F.L.S., F.E.S. ; Myddelton House, Waltham Cross.

Bowman, John Herbert; Greenham Common, Newbury.

Bradford Natural History and Microscopical Society ; Church Institute, North Parade, Bradford.

Breslau University Library ; Breslau, Germany.

Briggs, C. A., F.E.S. ; Rock House, Lynmouth, Deron.

Briggs, T. H., M.A., F.E.S.; Rock House, Lynmouth, Devon.

Brighton and Hove Natural History Society; Public Library, Brighton.

Bristol Municipal Public Libraries; Bristol.

Bristol Museum and Art Gallery; Queen's Road, Bristol.

Bristol Naturalists' Society ; 20 Berkeley Square, Bristol.

British Museum; Bloomsbury, W.C.

Brokenshire, Fred. R.; 7 Hillsboro' Avenue, Pennsylvania, Exeter.

Bromley Naturalists' Society; 92 London Road, Bromley, Kent.

Buchan-Hepburn, Sir Archibald, Bart., F.E.S.; SmeatonHepburn, Prestonkirk, N.B. 
Burr, Malcolm, D.Sc., F.L.S., F.G.S., F.Z.S., F.E.S.; Castle Hill House, Dover.

Burrows, The Rev. C. R. N., F.E.S.; Mucking Vicarage, Stanford-le-Hope, Essex.

Cambridge Philosophical Library; New Museums, Cambridge. Cambridge University Library; Cambridge.

Campbell, Francis Maule, F.L.S., F.E.S. ; Brynllwydwyn, Machynlleth.

Canterbury, Philosophical Institution of; Christchurch, New Zealand.

Cardiff Free Libraries; Cardiff.

Chapman, Thomas Algernon, M.D., F.Z.S., F.E.S. ; Betula, Reigate.

Cheltenham Natural Science Society; Public Library and Museum, Cheltenham.

Chester Society of Natural Science; Grosvenor Museum, Chester.

Chicago University Library; Chicago, Ill., U.S.A.

Christiania, University of ; Christiania, Norway.

Church, Sir William Selby, Bart., K.C.B., M.B.; 130 Harley Street, W.

Cleland, John, M.D., D.Sc., LL.D., F.R.S. ; Drumclog, Creukerne.

Colgan, Nathaniel, M.R.I.A.; 15 Breffni Terrace, Sandycove, Co. Dublin.

Collins, The Hon. Mrs. Henn, B.Sc., F.L.S.; Colins Farm, Durrington, Salisbury.

Congress, Library of ; Washington, D.C., U.S.A.

Copenhagen University Library; Copenhagen.

Cornell University Library; Ithaca, New York, U.S.A.

Cornwall, Royal Institution of ; Truro.

Cotton, John, M.R.C.S., F.E.S.; Simonswood, Prescot Road, St. Helens.

Cox, Benjamin Cornell ; Gilston, Largoward, Fifeshire. Crawford, W. C.; 1 Lockharton Gardens, Colinton Road, Edinburgh.

Crawshay, Lionel Rutledge, M.A.(Oxon); Marine Biological Laboratory, Plymouth.

Croydon Public Libraries; Town Hall, Croydon. 
Dames, Felix L. ; Steglitz-Berlin.

Davies, Arthur Ellson, Ph.D., F.L.S., F.C.S.; Tweedbank, West Savile Road, Edinburgh.

Derby Free Library and Museum ; Warduick, Derby.

Detroit Public Library; Detroit, Mich., U.S.A.

Dilks, Arthur C., B.Sc.; Tardebigge, Bromsgrove.

Doesburgh, S. C. van; Breestraat, Leiden, Holland.

Downing College; Cambridge.

Drinkwater, J. W., F.R.M.S.; St. Margarets, Wallington, Surrey.

Dublin, Royal, Society ; Leinster House, Dublin.

East Kent Natural History Society ; Medical Hall, Canterbury. Eastwood, John E., F.E.S. ; Enton Lodge, Witley, Godalming. Eddy, James Ray; The Grange, Carleton, Skipton.

Edinburgh Public Library; Edinburgh.

Edinburgh, Royal Society of ; Edinburgh.

Edinburgh University Library; Edinburgh.

Elliott, John, M.D., F.R.C.P. ; 24 Nicholas Street, Chester.

Elphinstone, Sir Howard W., Bart., M.A., F.L.S., F.R.G.S. ;

2 Stone Buildings, Iincoln's Inn, W.C., and Struan, Wimbledon Park, S.W.

England, Royal College of Surgeons of ; Lincoln's Inn Fields, W.C.

Fielding, Clement, M.P.S., Ph.C.; Clover Hill, Halifax. FitzGerald, The Rev. H. Purefoy, M.A., F.L.S., F.C.S.; Lidwells, Goudhurst, Kent.

Fletcher, Thomas Bainbrigge, R.N., F.L.S., F.Z.S., F.E.S.; Agricultural Research Institute, Pusa, Bihar, India.

Fletcher, W. H. B., M.A., F.Z.S., F.E.S.; Alduick Manor, Bognor.

Folkestone Free Public Library and Museum ; Folkestone. France, Institut de; Paris.

Friedländer \& Sohn; 11 Carlstrasse, Berlin, N.W. 6.

Friend, The Rev. Hilderic, F.R.M.S.; Wilmot Road, Swadlincote, Burton-upon-Trent.

Fuller, The Rev. Alfred, M.A., F.E.S.; The Lodge, Sydenliam Hill, S.E.

Garnett, Frank W., M.R.C.V.S.; Dalegarth, Windermere. 
Gascoigne, Major French; Lotherton Hail, Aberford, Leeds.

Geological Society of London; Burlington House, Piccadilly, W.

Gerold \& Co. ; Vienna.

Gibbs, Arthur Ernest, F.L.S., F.Z.S., F.E.S., F.R.H.S.; Kitchener's Meads, St. Albans.

Gibson, Miss; Hill House, Saffron Walden.

Giles, Harry M., F.E.S.; Zoological Society, South Perth, Western Australia.

Glasgow Natural History Society ; 207 Bath Street, Glasgow. Glasgow, Royal Philosophical Society of; 207 Bath Street, Glasgow.

Glasgow University Library; Glasgow.

Godman, F. DuCane, D.C.L., F.R.S., F.L.S., F.G.S., F.Z.S., F.E.S., F.R.H.S., Treasurer ; 45 Pont Street, Belgrave Square, S.W.: and South Lodge, Horsham.

Gooding, Henry Cornish; Ipswich Street, Stowmarket.

Göttingen University Library; Göttingen, Germany.

Great Britain, Royal Institution of ; Albemarle Street, W.

Green, E. Ernest, F.E.S.; Mote Hall, Bearsted, Maidstone.

Grosvenor Public Library; Buffulo, N.Y., U.S.A.

Guille-Allès Library; Guernse!..

Guitel, Fredéric, Professeur de Zoologie à la Faculté des

Sciences; Université de Rennes, France.

Gurney, Robert, F.Z.S.; Ingham Old Hall, Stalham.

Haileybury College; Hertford.

Halifax Public Library; Belle View, Halifax.

Hamburg, Naturhistoriche Museum zu; Steinthorwall, Hamburg, Germany.

Hardy, Alfred Douglas, F.L.S., F.R.M.S.; State Forests Department, Melboume, Victoria, Australia.

Harley, John, M.D., F.R.C.P., F.L.S. ; Beedings, Pulborough, Sussex.

Harmer, Sidney F., Sc.D., F.R.S., F.Z.S., Keeper of Zoology. British Museum, Vice-President; British Mruseum (Nat, Hist.) Cromwell Road, S.W., and 58 Albemarle Road, Beckenham.

Harvard Museum of Comparative Zoology; Cambridge, Mass., U.S.A. 
Hastings and St. Leonard's Natural History Society; The Museum, Hastings.

Heidelberg University Library ; Heidelberg, Germany. Hertfordshire County Museum; Hatfield Road, St. Albans. Hertfordshire Natural History. Society and Field Club ; Upton House, Watford.

Hewitt, David Basil, F.R.C.S.I.; Grove Mount, Davenham. Hope, G. P. ; Havering Grange, Romford.

Hopkinson, John, F.L.S., F.G.S., F.Z.S., F.R.M.S., F.R.Met. Soc., Assoc.Inst.C.E., Secretary; Weetwood, Wat.ford.

Huddersfield Naturalist and Photographic Society; The Technical College, Huddersfield.

Hull Public Libraries; Hull.

Illinois University Library; Urbana, Ill., U.S.A.

India, Geological Survey of; Calcutta.

Ireland, National Library of ; Kildare Street, Dublin.

Irish, Royal, Academy; 19 Dawson Street, Dublin.

Irving, John, M.D.; Inagh Mount, 15 Filey Road, Scarborough.

Jackson, B. Daydon, Ph.D., F.L.S., General Secretary of the Linnean Society; 21 Cautle! Avenue, Clapham Common, S.W.

James, Robert Denley, F.A.I. (Natal), F.R.M.S.; Earl's Croome, Durban, Natal (P.O. Box 212).

John Crerer Library; Chicago, Ill., U.S.A.

Jones, Albert H., F.E.S. ; Shrublands, Eltham.

Jones, William Llewellyn, F.R.M.S.; Manley Knoll, Helsby, Warrington.

Junk, W.; 201 Kurfurstendamm, Berlin, W. 15.

Kappel, August Wilhelm, F.L.S., F.E.S., Librarian of the Linnean Society ; Creeveroe, Golder's Green, N.W.

Kenrick, Sir G. H., F.E.S.; Whetstone, Somerset Road, Edgbaston, Birmingham.

Kiel University Library; Kiel, Germany.

Kilmarnock Public Library and Museum; Kilmarnock, N.B. King's Inn Library ; Dublin.

Knight, H. H. ; The Lodge, All Saints' Road, Cheltenham. 
Laver, Henry, M.R.C.S. ; 43 Head Street, Colchester.

Lebour, Miss Marie V., M.Sc.; Radcliffe House, Corbridge, Northumberland.

Leeds Philosophical and Literary Society; The Museum, Leeds. Leeds Public Free Libraries; Leeds.

Leeds University Library; Leeds.

Leicester Free Public Library; Wellington Street, Leicester.

Lewis, John Spedan, F.Z.S.; Spedan Tower, West Heath, Hampstead, N.W., and 278-288 Oxford Street, W.

Linnean Society of London ; Burlington House, Piccadilly, W. Liverpool Athen:eum; Liverpool.

Liverpool Free Public Libraries; Licerpool.

Liverpool Microscopical Society; Royal Institution, Liverpool. Tiverpool School of Tropical Medicine; Exchange Buildings, Liverpool.

London Library; 12 St. James's Square, S.W.

Longstaff, George Blundell, M.A., M.D., F.C.S., F.S.S.; Highiands, Putney Heath, S.W., and T'witchen, Morthoe, Deron.

Los Angeles Public Library; Califmmia, U.S.A.

Lyon Université Bibliothèque; Lyons, France.

McIntosh, W. Carmichael, M.D., LL.D., F.R.S.L.\&E., F.L.S., Professor of Natural History, University of St. Andrews; 2 Abbotsford Crescent, St. Andreus, N.B.

McMillan, William Singer, F.L.S.; Ardenholm, Maghull, Liverpool.

Magdalen College; Oxford.

Manchester Literary and Philosophical Society; 36 George Street, Manchester.

Manchester Microscopical Society ; 397 Cheetham Hill Road, Manchester.

Manchester Public Free Libraries; Manchester.

Marlborough College Natural History Society; Marlborough. Massey, W. H.; Twyford, Berks.

Meiklejohn, John William S., M.D., F.L.S.; 105 Holland Road, Kensington, W.

Melbourne Public Library; Mellourne, Australia.

Mennell, Henry Tuke, F.L.S.; 10 St. Dunstan's Buildings, Great Tourer Street, E.C. 
Michael, Albert Davidson, F.L.S., F.Z.S., F.R.M.S., F.R.H.S.,

Vice-President ; The Warren, Studland, Wareham.

Middlesbrough Free Libraries; Middlesbrough.

Mitchell Library; 21 Miller Street, Glasgow.

Moore, Henry; 12 Whiston Grove, Rotherham.

Morey, Frank, F.L.S.; Wolverton, Carisbrooke Road, Newport, Isle of Wight.

Morgan, Ralph ; 9 Clifton Hill, Exeter.

Moulton, John C., F.L.S., F.E.S. ; Kuching, Sarawak, Borneo. Munich Royal Library; Munich, Germany.

Muséum d'Histoire Naturelle; Paris.

Nebraska University Library; Lincoln, Neb., U.S.A.

Newcastle-upon-Tyne Literary and Philosophical Society; Westgate Road, Newcastle-upon-Tyne.

Newcastle-upon-Tyne Public Library; Nevcastle-upon-Tyne. New South Wales, Public Library of; Sydney, N.S.W.

New South Wales, Royal Society of; Sydney, N.S.W.

Newstead, Robert, M.Sc., F.R.S., A.L.S., F.E.S., Hon.F.R.H.S.,

Dutton Memorial Professor of Entomology; School of

Tropical Medicine, The University, Liverpool.

New York Public Library; New York, U.S.A.

Nicholson, Charles; Lansdowne House, Morley Street, Bradford.

Niemeyer, Dr. Max, Halle a Saale 1, Germany.

Noble, Sir Andrew, Bart., K.C.B., D.Sc., D.C.L., F.R.S.,F.C.S.,

F.R.A.S.; Jesmond Dene House, Newcastle-upon-Tyne.

Norfolk and Norwich Library; Norwich.

Norman, The Rev.A. Merle, M.A., D.C.L.,LL.D., F.R.S.,F.L.S.,

Hon. Canon of Durham; The Red House, Berkhamsted.

Northumberland, Durham, and Newcastle-upon-Tyne Natural

History Society; Hancock Museum, Newcastle-upon-Tyne.

North Staffordshire Field Club; Stone.

Norwich Free Library; Norwich.

Nottingham Free Public Libraries; Nottinglıam.

OKamura, Prof. K. ; 4 Nichone, Shin-oganamachi, Ushigome, Tokyo, Japan.

Oke, Alfred William, B.A., LL.M., F.L.S., F.G.S. ; 32 Denmark Villas, Hove, Brighton. 
Oldham, Charles, F.Z.S., M.B.O.U., Hon. Sec. Herts Nat. Hist. Soc.; Kelvin, Berkhamsted.

Ontario Agricultural College; Guelph, Canada.

Otago, University of ; Dunedin, New Zealand.

Owens College (Christie Library); Manchester.

Pack-Beresford, Denis R., D.L., B.A., M.R.I.A.; Fenagh, Bagenalstown, Co. Carlow, Ireland.

Paisley Philosophical Institution; 3 County Place, Paisley.

Peabody Institute; Baltimore, Maryland, U.S.A.

Perthshire Society of Natural Science; T'ay Street, Perth.

Philadelphia Academy of Natural Sciences; Philadelphia, Pa., U.S.A.

Pickard-Cambridge, The Rev. O., M.A., F.R.S.; Bloxworth Rectory, Wareham.

Plowman, T.; Nystuen Lodge, Bycullah Park, Enfield.

Plymouth Institution; Athenæum, Plymouth.

Portsmouth Free Public Library; Town Hall, Portsmouth.

Poulton, Edward B., M.A., D.Sc., LL.D., F.R.S., F.L.S.,

F.G.S., F.Z.S., Hope Professor of Zoology, University of

Oxford; Wykeham House, Oxford.

Preston Free Public Libraries and Museum; Preston.

Quaritch, Bernard ; 11 Grafton Street, Bond Street, W.

Queen's University; Belfast.

Quekett Microscopical Club; 20 Hanover Square, W.

Quelch, William Paul, F.R.B.S.; 65 Shakespeare Road, Hanwell, W.

Radcliffe Library; Museum, Oxford.

Rashleigh, Evelyn William; Stoketon, Saltash.

Robertson, James Alexander; Lune Vieu, Fleetwood.

Rotherham Naturalists' Society; 6 Whiston Grove, Rotherhan. Rothschild, The Hon. Lionel Walter, Ph.D., F.R.S., F.L.S.,

F.Z.S., Pres. Herts Nat. Hist. Soc.; Tring Park, Tring.

Royal Academy of Sciences; Amsterdam.

Royal Academy of Sciences; Stockholm, Sweden.

Royal College of Science; Dublin.

Royal Microscopical Society; 20 Hanover Square, W.

Royal Society ; Burlington House, Piccadilly, W. 
St. Albans Public Library; St. Albans.

St. Andrews University Library; St. Andrews, N.B.

St. Catharine's College ; Cambridge.

Salisbury Microscopical Society; 14 Wyndham Terrace, Salisbury.

Scharff, Robert Francis, Ph.D., B.Sc., F.L.S., F.Z.S., VickPresidentr; Knockranny, Bray, co. Wicklow.

Schmidle, Prof. W.; Villa Hansagarten, Konstang, Baden, Germany.

Schmidt, Max, Ph.D. ; 95 iv Eppendorfer, Landstrasse, Hamburg.

Scott, Thomas, LL.D., F.L.S.; 2 Devanha Terrace, Aberdeen. Scottish, Royal, Museum; Edinburgh.

Scourfield, David Joseph, F.Z.S., F.R.M.S.; 63 Queen's Road, Leytonstone, N.E.

Sears, R. S. Wilson; 1 Lisson Grove, Marylebone, N.W.

Selborne Society ; 42 Bloomsbury Square, W.C.

Sheffield Literary and Philosophical Society; Leopold Street, Sheffield.

Sidney-Sussex College; Cambridge.

Sion College Library; Victoria Embanlement, E.C.

Soar, Charles David, F.L.S., F.R.M.S. ; 37 Dryburgh Road, Putney, S.W.

Somersetshire Archæological and Natural History Society; The Castle, Tunnton.

Southport Free Library; Southport.

Spicer, Henry, B.A., F.L.S., F.G.S.; 14 Aberdeen Park, Highbury, N.

Sprague, T. B., M.A., LL.D.; 29 Buckingham Terrace, Edinburgh.

Stazione Zaologica; Naples.

Stechert, G. E.; 2 Star Yard, Carey Street, W.C.

Stoke Newington Public Libraries; Church Street, N.

Storey, J. E.; 26 Grosvenor Roud, Whulley Range, Manchester.

Sunderland Library and Literary Society; Fawcett Street, sunderland.

'Taverner, Henry, F.R.MI.S.; 319 Seven Sisters' Road, Finsbury Paik, N. 
Tindall, William B.; 39 St. Mary Street, and 1315 Traders Bank Buildings, Toronto, Canada.

Toronto, University of ; Toronto, Canada.

Torquay Natural History Society; Museum, Babbacombe Road, Torquay.

Trinity College; Cambridge.

Trinity College; Dublin.

Trondhjem, Royal Library of ; Trondhjem, Norway.

Tupman, Lt.-Col. George Lyon, F.G.S., F.Z.S., F.R.A.S.,

F.R.M.S.; Hillfoot Observatory, College Road, Harrow.

Turner, Charles; 20 Minster Road, Cricklewood, N.W.

University College ; Cor $\%$.

University College, London; Gower Street, W.C.

Upsala Royal University Library; Upsala, Sweden.

Victoria Institute ; Worcester.

Wailes, George Herber't, F.L.S.; Vancouver, B.C. (c/o G. Wailes \& Co., 386 Euston Road, N.W.)

Wales, National Library of ; Aberystwyth.

Walker, Alfred O., F.L.S., F.Z.S.; Ulcombe Place, Maidstone. Walsingham, The Right Hon. Lord, M.A., LL.D., F.R.S., F.L.S., F.Z.S., F.E.S., M.B.O.U.; Merton Hall, Thetford.

Warrington Municipal Museum; Warrington.

Webb, Wilfred Mark, F.L.S., F.R.M.S., Hon. Sec. Selborne Society; Odstock, Hanwell, W., and 42 Bloomsbury Square, W.C.

Weg, Max; 1 Leplaystrass, Leipzig.

Weigel, Oswald ; 1 Königstrasse, Leipzig.

Wesley, E. F., A.K.C. ; 28 Essex Street, Strand, W.C.

West Kent Natural History Society; 42 Shooter's Hill Road, Blackiheath, S.E.

West, William, F.L.S. ; 26 Woodrille Terrace, Bradford.

Whittle, F. G.; 3 Marine Avenue, Southend-on-Sea.

Williamson, William; 9 Plewlands Terrace, Edinburgh.

Wilson, H. Maclean, M.D., B.Sc., Chief Inspector, West Riding of Yorkshire Rivers Board; Wakefield.

Wilson, Joseph, F.R.M.S.; Hillside, Aron Road, Upper Walthamstow, N.E. 
Wood, J. H., M.B. ; Tarrington, Ledbury.

Worssam, Cecil ; 29 Ashburnham Road, Bedford.

Yale University Library; New Haven, U.S.A.

Yorkshire Philosophical Society; Museum, York.

Zoological Society of London; Regent's Park, N.W.

The Advocate's Library, Edinburgh ; the Bodleian Library, Oxford; the British Museum; Cambridge University Library; 'Trinity College, Dublin; and the National Library of Wales; entered in the List, receive the Society's publications in accordance with the Copyright Act. 


\section{GEOGRAPHICAL LIST OF THE SOCIETY.}

(Beyond the limits of the London Postal District.)

\section{GREAT BRITAIN AND IRELAND. \\ ENGLAND.}

BEDFORDSHIRE.

Bedford-Worssam, C.

BERKSHIRE.

Newbury-Bowman, J. H. Twyford-Massey, W. H.

Buckinghamshire.

Slough-Bentley, R.

Cambridgeshire.

Cambridge-Assheton, $\mathrm{R}$.

Downing College.

Philosophical Library.

St. Catherine's College.
Cambridge-Sidney-Sussex College.

- Trinity College.

_.._- University Library.

Cheshire.

Chester-Elliott, Dr. J.

Davenham.-Hewitt, D. B.

Society of Natural Science. Helsby - Jones, W. L.

Cornwall.

Saltash-Rashleigh, E. W.

Truro-Royal Institution of Cornwall.

Derbyshire.

Derby-Free Library and Museum.

Devonshire.

Exeter-Brokenshire, F. R.

Morgan, $\mathrm{R}$.

Lynmouth-Briggs, C. A.

Briggs, T. H.

Mortehoe-Longstaff, Dr. G. B.

Wareham-Michael, A. D.

\section{Dorsetshire.}

Plymouth-Crawshay, L. R.

Plymouth Institution.

Torquay-Natural History Society.

areham-Pickard-Cambridge, Rev. O. P.

DURham.

Sunderland-Library and Literary Society. 


\section{Essex.}

Colchester-Laver, $\mathrm{H}$.

Romford-Hope, G.

Saffron Walden-Gibson, Miss.
Southend-Whittle, F. G.

Stanford - le - Hope - Burrows, Rev. C. R. N.

Gloucestershire.

Bristol-Museum.

Naturalists' Society. Public Libraries.

Cheltenham-Knight, H. H. Natural Science Society.

\section{HAMPSHIRE.}

Newport, I.W.-Morey, F.

Portsmouth-Free Public Library.

Herefordshire.

Ledbury-Wood, J. H.

Hertfordshire.

Berkhamsted - Norman, Canon St. Albans.-Public Library.

A. M.

Oldham, C.

Hertford-Haileybury College.

St. Albans-Gibbs, A. E.

Museum.

County
Tring-Rothschild, Hon. W.

Waltham Cross-Bowles, E. A. Watford-Barraud, P. J.

Hertfordshire Natural History Society. Hopkinson, J.

Kent.

Beckenham-Harmer, Dr. S. F. Farnborough-Avebury, Lord. Bromley-Naturalists' Society. Canterbury -East Kent Natural History Society.

Dover-Burr, Dr. M. Eltham-Jones, A. H. - Walker, A. O. Folkestone-Free Public Library and Museum.

Goudhurst-Fitzgerald, Rev. H. Maidstone-Green, E. E.

\section{LANCASHIRE.}

Barrow-in-Furness-Public Lib- Manchester-Literary and Philo-

rary.

Fleetwood-Robertson, J. A. Liverpool-Bootle Free Library.

L_- Free Public Libraries.

Liverpool Athenæum.

Macmillan, W. S.

Microscopical Society.

Newstead, Prof. R.

cine. sophical Society.

Microscopical Society.

Owens College.

Public Free Libraries.

Storey, J. E.

Preston-Free Public Libraries.

St. Helens-Cotton, J.

Southport-Free Library.

Warrington - Municipal $\mathrm{Mu}$ seum. 
Leicestershire.

Leicester-Free Public Library.

\section{Middlesex.}

Enfield-Plowman, T.

Harrow-Tupman, Lt.-Col. G.L.

\section{NoRFoLK.}

Norwich-Free Library.

Stalham-Gurney, R. Library.

Norfolk and Norwich Thetford-Walsingham, Lord.

\section{NoRthUMBERLAND.}

Corbridge-Lebour, Miss M. V. Newcastle-upon-Tyne - Noble, Newcastle - upon - Tyne - Arm- Sir A. strong College.

Literary and Philosophical Society. ral History Society. Public Library.

\section{NotTinghamshire.}

Nottingham-Free Public Libraries.

\section{OXFORDSHIRE.}

Oxford-Bodleian Library. Magdalen College.

Oxford-Poulton, Prof. E. B.

\section{SoMERSETSHIRE.}

Crewkerne-Cleland, Dr. J.

Taunton-Somersetshire Natural History Society.

STAFFordshire.

Burton-upon - Trent - Friend, Stone - North Staffordshire Rev. H. Stone-Bostock, E. D. Field Club. Radcliffe Library. 
WESTMORELAND.

Windermere-Garnett, F. W.

WILTSHIRE.

Marlborough-College Natural Salisbury-Collins, Hon. Mrs. H. History Society. Microscopical Society.

\section{WORCESTERSHIRE.}

Bromsgrove-Dilks, A. C.

Worcester-Victoria Institute.

Yorkshire.

Bradford-Bagshaw, W.

Leeds-University Library.

- Natural History and Middlesbrough-Free Libraries. Microscopical Society. Rotherham-Moore, H.

Nicholson, C.

West, W.

Halifax-Fielding, C.

Public Library.

Huddersfield - Naturalist and

Photographic Society.

Hull-Public Libraries.

Leeds-Gascoigne, Major F.

Philosophical Society.

Public Free Libraries.

Naturalists' Society.

Scarborough-Irving, Dr. J.

Sheffield-Literary and Philosophical Society.

Skipton-Eddy, J. R.

Wakefield-Binks, Mrs. I.

Wilson, Dr. H. M.

York-Yorkshire Philosophical Society.

\section{WALES.}

Cardiganshire.

Aberystwyth-National Library of Wales.

Glamorganshire.

Cardiff-Free Libraries.

Montgomeryshire.

Machynlleth-Campbell, F. M.

SCOTLAND.

Aberdeenshire.

Aberdeen-Scott, Dr. J.

Aberdeen-University Library.

Arrshire.

Kilmarnock-Public Library and Museum.

EDINBURGHSHIRE.

Edinburgh-Advocates' Library. Edinburgh-Royal Scottish MuCrawford, W. C.

Davies, Dr. A. E.

Public Library.

Royal Society. seum.

_ Sprague, Dr. T'. B.

University Library.

Williamson, W.

\section{Fifeshire.}

Largoward-Cox, B. C.

St. Andrews-University LiS't. Andrews - McIntosh, Prof. brary.

W. C. 
Haddingtonshire.

Prestontirk-Buchan-Hepburn, Sir A.

LANARKSHIRE.

Glasgow-Mitchell Library. Glasgow-Royal Philosophical Natural History Society. Society. University Library.

\section{Perthshire.}

Perth-Perthshire Society of Natural Science.

Renfrewshire.

Paisley-Philosophical Institution.

\section{IRELAND.}

\section{Antrim.}

Belfast-Belfast Library.

Belfast-Queen's University.

Carlow.

Bagenalstown-Pack-Beresford, D. R.

Cork.

Cork-University College.

DUBLIN.

Dublin-King's Inn Library.

National Library of Ireland.

Royal College of Science.
Dublin-Royal Dublin Society. Royal Irish Academy. Trinity College.

WrCKLOW.

Bray-Scharff, Dr. R. F.

CHANNEL ISLANDS.

Guernsey-Guille-Allès Library.

\section{BRITISH DOMINIONS.}

AFRICA, SOUTH.

Cape Colony.

Grahamstown-Albany Museum.

Natal.

Durban-James, R. D.

ASIA.

Borneo.

Sarawali-Moulton, J. C. 


\section{AUSTRALIA.}

New South Wales.

Sydney-Australian Museum. Sydney-Royal Society of New Public Library of New South Wales.

South Wales.

South Australia.

Adelaide-Public Library.

VICTORIA.

Melbourne-Hardy, A. D. Melbourne-Public Library.

Western Australia.

South Perth-Giles, H. M.

CANADA.

British Columbia.

Vancouver-Wailes, G. H.

Ontario.

Guelph - Ontario Agricultural Toronto-Tindall, W. B.

College.

—_ University.

INDIA.

Bihar-Fletcher, T. B.

Calcutta-Geological Survey of India.

NEW ZEALAND.

Christchurch-Philosophical In- Dunedin-University of Otago. stitution of Canterbury.

\section{FOREIGN COUNTRIES.}

\section{AMERICA, UNITED STATES OF.}

\section{California.}

Los Angeles-Public Library.

Columbia, District of.

Washington-Library of Congress.

ILLINoIs.

Chicago-John Crerer Library. Urbana-Illinois University LibUniversity Library. rary.

MaRYLand.

Baltimore-Peabody Institute.

Massachusetts.

Boston-Public Library.

Cambridge-Harvard Museum of Society of Natural His- Comparative Zoology. tory. 
Michigan.

Detroit-Public Library.

Nebraska.

Lincoln-Nebraska University.

New Haven.

Yale-University Library.

New York.

Buffalo-Grosvenor Public Lib- New York-American Museum rary.

Ithaca-Cornell University. of Natural History.

\section{Pennspluania.}

Philadelphia-Academy of Natural Sciences.

AUSTRIA.

Vienna-Gerold \& Co.

DENMARK.

Copenhagen-University Library.

FRANCE.

Lyons-Lyon Université Biblio- Paris-Muséum d'Histoire Nathèque. turelle.

Paris-Bibliothèque Nationale. Rennes-Guitel, Prof. F.

- Institut de France.

\section{GERMANY.}

Baden-Schmidle, Prof. W.

Berlin-Dames, F. L.

Friedländer \& Sohn.

- Junk, W.

- Royal Library.

\section{Museum.}

Breslau-University Library.

Franlifort-Baer \& Co.

Göttingen-University Library.
Halle a Saale-Niemeyer, Dr. M. Hamburg-Naturhistoriche Museum. Schmidt, Dr. M.

Heidelberg-University Library. Kiel-University Library. Leipzig-WVeg, M. -1 Weigel, $\mathrm{O}$. Munich-Royal Library.

HOLLAND.

Leiden-Doesburgh, S. C. van.

ITALY.

Naples-Stazione Zoologica.

JAPAN.

Tokyo-OKamura, Prof. K. 
NETHERLANDS.

Amsterdam-Royal Academy of Sciences.

NORWAY.

Bergen-Museums Bibliotek. Trondhjem-Royal Library. Christiana-University.

\section{SWEDEN.}

Stockholm-Royal Academy of Upsala-University Library. [Sciences.

$$
\text { SWITZERLAND. }
$$

Berne-Natural History Museum. 


\section{LIST OF THE PUBLICATIONS \\ ог म}

\section{R A Y SOCIETY.}

\section{Fior the First Year, 1844.}

1. Reports on the Progress of Zoology and Botany, 1841, 1842. viii $+496+\mathrm{xx}$ pp. 8vo. $184 \check{\text {. }}$

The State of Zoology in Europe, as regards the Vertebrata. By

C. L. Bonaparte. Transl. hy H. E. Strrickland. pp. 1-44.

The Progress of Zoology in 1842. Transl. from the German by W. B. MaCDONALD. pp. 1-348.

The Progress of Physiological Botany in 1841. By H. F. Link. Transl. by Edwin LaNKESTER. pp. 1-104. Index, pp. i-xx.

2. A Monograph of the British Nudibranchiate Mollusca. By Joshua Alder and Albany Hancock. Part I. $x+20$ pp., 10 plates. Folio. 1845.

3. Memorials of John RaY, consisting of his Life by Dr. Derham ; . . . with his Itineraries, etc. Edited by Edwin LAnkester. $\quad$ xii +220 pp. 8 vo. 1846.

\section{For the Second Year, 1845.}

4. On the Alternation of Generations. By J. J. S. Steenstrup. Transl. from the German version of C. H. Lorenzen by George Busk. viii + 132 pp., 3 plates. 8vo. 1845.

5. A Monograph of the British Nudibranchiate Mollusca. By Joshua Alder and Albany Hancock. Part II. iv + 34 pp., 13 plates. Folio. 1846.

6. Reports and Papers on Botany. viii +494 pp., 7 plates. 8 vo. 1846.

On the Morphology of the Coniferæ. By J. J. Zuccarini. Transl. by GeORge Busk. pp. 1-54, 441-444, pls. i-v.

Report on Botanical Geography, 1842. By A. Grisebach. Transl. by W. B. Macdonald. pp. 55-212.

Memoir on the Nuclei, Formation, and Growth of Vegetable Cells. By Carl Nägeli. Transl. by Arthur Henfrey. pp. 213-292, 445459 , pls. vi, vii.

Report on Physiological Botany, 1842 and 1843. By H. F. Link.

'Transl. by J. Hudson. pp. 293-440. Index pp. 461-494. 
For the Third Year, 1846.

7. Outlines of the Geography of Plants. By F. J. F. Meyen. Transl. by Margaret Johns'ton. $x+422$ pp., 1 plate. 8 vo. 1846 .

8. 'The Organization of 'l'rilobites. By Hermann Burmeister. Edited by Thomas Bell and Edward Forbes. xii +136 pp., 6 plates. Folio. 1846.

9. A Monograph of the British Nudibranchiate Mollusca. By Joshua Alder and Albany Hancock. Part III. iv +30 pp., 12 plates. Folio. 1847.

\section{For the Fourth Year, 1847.}

10. Elements of Physiophilosophy. By Lorenz Oken. From the German by Alfred 'I'vlk. $\mathrm{xx}+666$ pp. 8vo. 1847.

11. Reports on Zoology for 1843, 1844. Transl. from the German by George Busk, Alfred 'Tulk, and A. H. Haliday. viii +596 pp. 8 vo. 1847 .

Progress of Zoology in 1843. pp. 1-232.

Index, pp. 565"596.

1844. pp. 233-564.

12. A Monograph of the British Naked-eyed Medusæ. By Edward Forbes. viii +104 pp., 13 plates. Folio. 1848.

$$
\text { For the Fifth Year, } 1848 .
$$

13. Bibliographia Zoologiæ et Geologix. A General Catalogue of all Books, Tracts, and Memoirs on Zoology and Geology. By Lours Agassiz. Edited by H. E. Strickland. Vol. I. Periodicals, and A-B. xxvi +506 pp. 8 vo. 1848.

14. The Correspondence of John Ray. Edited by Edwin LAANKESTER. $\quad$ xvi +502 pp., 2 plates. 8vo. 1848.

15. A Monograph of the British Nudibranchiate Mollusca. By Joshua Alder and Albany Hancock. Part IV. iv + 28 pp., 12 plates. Folio. 1848.

\section{For the Sixth Year, 1849.}

16. Reports and Papers on Botany. Edited by Arthur Henfrey. viii +514 pp., 3 plates. 8vo. 1849.

On the Structure of the Palm-stem. By H. von Mонц. pp. 1-92, 495, pl. i.

On the Nuclei, Formation, and Growth of Vegetable Cells. By CARL NäGelI. Part II. pp. 93-158, 495-502, pls. ii, iii.

On the Utricular Structures in the Contents of Cells. By CARL NÄGELI. pp. 159-190.

Report on Physiological Botany for 1844 and 1845. By H. T'. Link. pp. 191-314. 
Report on Geographical Botany for 1844. By A. Grisebach. pp. 315-4.14.

Report on Geographical and Systematic Botany for 1845. By A. Grisebach. pp. 415-494.

17. The Natural History of the British Entomostraca. By W. Baird. viii + 364 pp., 36 plates. 8vo. 1850.

\section{For the Seventh Year, 1850.}

18. Bibliographia Zoologiæ et Geologiæ. A General Catalogue of all Books, Tracts, and Memoirs on Zoology and Geology. By Louis Agassiz. Edited by H. E. Strickland. Vol. 11. C-F. iv + 492 pp. 8vo. 1850 .

19. A Monograph of the British Nudibranchiate Mollusca. By Joshda Alder and Albany Hancock. Part V. iv +62 pp., 16 plates. Folio. 1851.

\section{For the Eighth Year, 1851.}

20. The British Species of Angiocarpous Lichens, elucidated by their Sporidia. By the Rev. W. A. Leighton. vi +102 pp., 30 plates. 8 vo. 1851.

21. A Monograph of the Sub-class Cirripedia. By Charles Darwin. The Lepadidæ, or Pedunculated Cirripedes. xii + 400 pp., 10 plates. 8 vo. 1851.

\section{For the Ninth Year, 1852.}

22. Bibliographia Zoologiæ et Geologiæ. A General Catalogue of all Books, Tracts, and Memoirs on Zoology and Geology, By Louis Agassiz. Edited by H. E. Strickland. Vol. III. G-M. vi + 658 pp. 8vo. 1852.

23. A Monograph of the British Nudibranchiate Mollusca. By Joshua Alder and Albany Hancock. Part VI. iv +62 pp., 12 plates. Folio. 1852.

\section{For the Tenth Year, 1853.}

24. Botanical and Physiological Memoirs. Edited by Arthur Henfrey. xvi +568 pp., 6 plates. 8vo. 1853.

'The Phenomenon of Rejuvenescence in Nature. By Alrxander

Braun. pp. vii-xxvi, 1-342, pls. i-v.

The Animal Nature of Diatomeæ. By G. Mrinigini. pp. 343-514.

The Natural History of Protococcus pluvialis. By Ferdinand Coнn. pp. 515-564, pl. vi.

25. A Monograph of the Sub-class Cirripedia. By Charles Darwin. The Balanidæ, the Verrucidæ, etc. viii +684 pp., 30 plates. 8 vo. 1854 . 
For the Eleventh Year, 1854.

26. Bibliographia Zoologiæ et Geologiæ. A General Catalogue of all Books, Tracts, and Memoirs on Zoology and Geology. By Louis Agassiz. Edited by H. E. Strickland. Vol. IV. N-Z. vi + 604 pp. 8vo. 1854.

For the Tuelfth Year, 1855.

27. A Monograph of the British Nudibranchiate Mollusca. By Joshua Alder and Albany Hancock. Part VII. vi +54 $+40+$ xlvi pp., 9 plates. Folio. 1855 .

\section{For the Thirteenth Year, 1856.}

28. A Monograph of the Fresh-water Polyzoa, including all the known species, both British and Foreign. By GEorge James Allman. viii $+122+22$ pp., 11 plates. Folio. 1856 [1857].

\section{For the Fourteenth Year, 1857.}

29. The Recent Foraminifera of Great Britain. By William Crawford Wildiamson. $\mathrm{xx}+108$ pp., 7 plates. Folio. 1858.

For the Fifteenth Year, 1858.

30. The Oceanic Hydrozoa; a Description of the Calycophoridæ and Physophorida. . . By Thomas Henry Huxley. $\mathrm{x}+144+24$ pp., 12 plates. Folio. 1859.

\section{For the Sixteenth Year, 1859.}

31. A History of the Spiders of Great Britain and Ireland. By John Blackwall. [Part I.] vi $+174+24$ pp., 12 plates. Folio. 1861.

\section{For the Seventeenth Year, 1860.}

32. Introduction to the Study of the Foraminifera. By William B. Carpenter, assisted by William K. Parker and T. Rupert Jones. xxii $+320+44$ pp., 22 plates. Folio. 1862.

\section{For the Eighteenth Year, 1861.}

33. On the Germination, Development, and Fructification of the Higher Cryptogamia, and on the Fructification of the Coniferæ. By Wilhelm Hofmeister. Transl. by Frederick Currey. xviii +506 pp., 65 plates. 8 vo. 1862. 
For the Nineteenth Year, 1862.

34. A History of the Spiders of Great Britain and Ireland. By Јонм Blackwall. Part II. iv + $210(175-384)+34$ pp., 17 plates. Folio. 1864 .

\section{For the Twentieth Year, 1863.}

35. The Reptiles of British India. By Albert C. L. G. Günther. xxviii + 452 pp., 26 plates. Folio. 1864.

\section{For the Twenty-first Year, 1864.}

36. A Monograph of the British Spongiadæ. By J. S. Bowerbank. Vol. I. $x x+290$ pp., 37 plates. 8vo. 1864.

For the Twenty-second Year, 1865.

37. The British Hemiptera. Vol. I. Hemiptera-Heteroptera. By John William Douglas and John Sco't. xii $+628+$ 42 pp., 21 plates. 8 vo. 1865.

38. A Monograph of the British Spongiadx. By J. S. Bowerbank. Vol. II. $\mathrm{xx}+388$ pp. 8vo. 1866.

\section{For the Twenty-third Year, 1866.}

39. The Miscellaneous Botanical Works of Robert Brown. [Edited by John J. Bennetr.] Vol. I, containing I, Geographico-botanical, and II, Structural and Physiological Memoirs. viii +612 pp. 8vo. 1866.

40. Recent Memoirs on the Cetacea. Edited by WILLIA Henry Flower. xii + 312 pp., 6 plates. Folio. 1866.

I. On the Greenland Right-Whale. By D. F. Eschricht and J. REINHARDT. pp. 1-150, pls. i-vi.

II. On the Species of the Genus Orca inhabiting the Northern Seas. By D. F. Eschricht. pp. 151-188.

III. Pseudorca crassidens, a Cetacean hitherto unknown in the Danish Fauna. By J. REINHARDT. pp. 189-218.

IV. Synopsis of the Cretaceous Mammalia of Scandinavia (Norway and Sweden). By W. Lillueborg. pp. 219-310.

41. Nitzsch's Pterylography, translated from the German. Edited by Phılip Lutley Sclater. xii + 182 pp., 10 plates. Folio. 1867.

\section{For the Tuenty-fourth Year, 1867.}

42. A Monograph on the Structure and Development of the Shoulder-girdle and Sternum in the Vertebrata. By W. Kitchen Parker. xii $+240+60$ pp., 30 plates. Folio. 1868. 
43. The Miscellaneous Botanical Works of RoBert Brown. [Edited by John J. Benneтt.] Vol. II, containing III, Systematic Memoirs, and IV, Contributions to Systematic Works. viii +780 pp. 8vo. 1868.

For the Tuenty-fifth Year, 1868.

44. 'The Miscellaneous Botanical Works of RoBer'c Brown. [Edited by John .J. Bennetr.] Vol. III. Atlas of Plates. iv + 16 pp., 38 plates. Folio. 1868.

45. Vegetable 'Teratology, an Account of the Principal Deviations from the Usual Structure of Plants. By Maxwell T. Masters. With numerous illustrations by E. M. Williams. xxxviii + 534 pages. 8vo. 1869.

\section{For the Tuenty-sixth Year, 1869.}

46. A Monograph of the Gymnoblastic or 'Tubularian Hydroids. By George James Allman. Part I, the Hydroida in General. xxii $+154+24$ pp., 12 plates. Folio. 1871.

For the Twenty-seventh Year, 1870.

47. A Monograph of the Gymnoblastic or Tubularian Hydroids. By George James Aluman. Conclusion of Part I, and Part II, containing descriptions of the Gene:a and Species of the Gymnoblastea. iv + 2 (xxiii, xxiv) + 296 (155-450) + 22 pp., 11 plates (xiii-xxiii). Folio. 1872.

For the Twenty-eighth Year, 1871.

48. Monograph of the Collembola and Thysanura. By Sir Jонn Luввоск. $\mathbf{x}+276$ pp., 78 plates. 8vo. 1873.

For the Tuenty-ninth Year, 1872.

49. A Monograph of the British Annelids. By W. C. McIntosh. Part I. The Nemertians. xiv $+96+20$ pp., 10 plates. Folio. 1873.

For the Thirtieth Year, 1873.

50. A Monograph of the British Annelids. By W. C. McIntosh. Part I continued. The Nemertians. iv +122 $(97-214,213 a-d)+26$ pp., 13 plates (xi-xxiii). Folio. 1874.

For the Thirty-first Year, 1874.

51. A Monograph of the British Spongiadæ. By J. S. Bowerbank. Vol. III. xxviii +368 pp., 92 plates. 8vo, 1874. 
For the Thirty-second Year, 1875.

52. A Monograph of the British Aphides. By George Bowdler Buckton. Vol. I. $\mathrm{x}+194+78$ pp., 42 plates (A-C, i-xxxviii, iv bis). 8vo. 1876.

\section{For the Thirty-third Year, 1876.}

53. A Monograph of the Free and Semi-parasitic Copepoda of the British Islands. By G. Stewardson Brady. Vol. I. iv $+148+72$ pp., 36 plates $\left(1-33,10 \mathrm{~A}, 24_{\mathrm{A}}, 24 \mathrm{~B}\right)$. 8vo. 1878.

For the Thirty-fourth Year, 1877.

54. A Monograph of the British Aphides. By George Bowdler Buck'on. Vol. II. iv $+176+100$ pp., 50 plates (xxxix-lxxxvi, li bis, lxix bis). 8vo. 1879.

For the Thirty-fifth Year, 1878.

55. A Monograph of the Free and Semi-parasitic Copepoda of the British Islands. By G. Stewardson Brady. Vol. II. iv $+182+98$ pp., 49 plates (34-82). 8vo. 1880.

For the Thirty-sixth Year, 1879.

56. A Monograph of the Free and Semi-parasitic Copepoda of the British Islands. By G. Steiwardson Brady. Vol. III. iv + 84 + 22 pp., 11 plates (83-93). 8vo. 1880.

57. A Monograph of the British Spongiadx. By the late J. S. Bowerbank. Vol. IV (Supplementary). Edited, with additions, by the Rev. A. M. Norman. xviii $+250+34$ pp., 17 plates. 8vo. 1882.

\section{For the Thirty-seventh Year, 1880.}

58. A Monograph of the British Aphides. By George Bowdler Buck'on. Vol. III. vi $+142+56$ pp.; 28 plates (lxxxvii-cxiv). 8vo. 1881.

F'or the Thirty-eighth Year, 1881.

59. A Monograph of the British Phytophagous Hymenoptera. By Peter Cameron. Vol. I. viii $+340+42$ pp., 21 plates. 8vo. 1882.

For the Thirty-ninth Year, 1882.

60. A Monograph of the British Aphides. By George BowdLer BucK'ToN. Vol. IV. $x+228+62$ pp., 27 plates D-I, exiv bis, cxv-cxxxiv). 8vo. 1883. 
For the Fortieth Year, 1883.

61. British Oribatidæ. By Alber' D. Michael. Vol.I. xii $+336+62$ pp., 31 plates (i-xxiv, A-G). 8vo. 1884.

For the Forty-first Year, 1884.

62. A Monograph of the British Pliytophagous Hymenoptera. By Peter Cameron. Vol. II. vi $+234+54$ pp., 27 plates. 8 vo. 1885.

For the Forty-second Year, 1885.

63. The Larvæ of the British Butterflies and Moths. By the late Wildiam Buckler. Tol. I. ('I'he Butterflies.) Edited by H. T. Stainton. xvi $+202+34$ pp., 17 plates. 8vo. 1886.

\section{For the Forty-third Year, 1886.}

64. The Larve of the British Butterflies and Moths. By the late Wiluiam Buckitir. Vol. II. ('The Sphinges or Hawkmoths and part of the Bombyces.) Edited by H.'I. Stainton. xii $+172+36$ pp., 18 plates (xviii-xxxv). 8vo. 1887.

For the Forty-fourth Year, 1887.

65. British Oribatidie. By Albert D. Michael. Vol. II. xii $+322(337-658)+62$ pp., 31 plates (xxv-liv, xlviia). 8vo. 1888.

For the Forty-fifth Year, 1888.

66. 'The Larve of the British Butterflies and Moths. By the late Wilijam Bucklér. Vol. III. ('The concluding portion of the Bombyces.) Edited by H. 'T. Stainton. xvi + $80+36$ pp., 18 plates (xxxvi-liii). 8vo. 1889.

$$
\text { For the Forty-sixth Year, } 1889 .
$$

67. A Monograph of the British Phytophagous Hymenoptera. By Peter Cameron. Vol. III. vi $+274+34$ pp., 17 plates. 8vo. 1890.

\section{For the Forty-serenth Yeur, 1890.}

68. The Larvæ of the British Butterflies and Moths. By the late William Buckler. Vol. IV. ('The first portion of the Noctuæ.) Edited by H. 'I'. Strainton. xii $+116+32$ pp., 16 plates (liv-lxix). 8vo. 1891. 


\section{For the Furty-eighth Year, 1891.}

69. The Larvæ of the British Butterflies and Moths. By the late William Buckler. Vol. V. (The second portion of the Noctuæ.) Edited (in part) by the late H. T. Strainton. xii $+90+34$ pp., 17 plates (lxx-lxxxvi). 8vo. 1893.

\section{For the Forty-ninth Year, 1892.}

70. A Monograph of the British Phytophagous Hymenoptera. By Peiter Cameron. Vol. IV. vi + $248+38$ pp., 19 plates. 8vo. 1893.

\section{For the Fiftieth Year, 1893.}

71. The Larvæ of the British Butterflies and Moths. By the late William Buckler. Vol. VI. ('I'he third and concluding portion of the Noctuæ.) Edited by Geo. 'T. Porri'l'I. xii $+142+38$ pp., 19 plates (lxxxvii-cv). 8vo. 1895.

\section{For the Fifty-first Year, 1894.}

72. 'The Larvæ of the British Butterflies and Moths. By the late Wildiam Bucklek. Vol. VII. (The first portion of the Geometræ.) Edited by Geo. T. PorritT. xvi $+176+$ 44 pp., 22 plates (cvi-cxxvii). 8vo. 1897.

\section{For the Fifty-second Year, 1895.}

73. 'The Larvæ of the British Butterflies and Moths. By the late William Buckler. Vol. VIII. ('The concluding portion of the Geometræ.) Edited by Geo. 'T. Porki'r'. xii $+120+70$ pp., 20 plates (cxxviii-cxlvii). 8vo. 1899.

For the Fifty-third Year, 1896.

74. The Tailless Batrachians of Europe. By G. A. Boulenger. Part I. viii + 210 pp., 10 plates. 8vo. 1897.

Fur the Fifty-fourth Year, 1897.

75. The Tailless Batrachians of Europe. By G. A. Boulenger. Part II. ii +166 (211-376) pp., 14 plates (xi-xxiv). 8vo. 1898.

\section{IOr the Fifty-fifth Year, 1898.}

76. A Monograph of the British Annelids. By William Carmichael McIntosh. Part II. Polychæta. Amphinomidæ to Sigalionidæ. $x+228(215-442)+40$ pp., 20 plates (xxiv-xlii, xxviA). Folio. 1900. 
For the Fifty-sixth Year, 1899.

77. The Larvæ of the British Butterflies and Moths. By the late Wildiam Buckler. Vol. IX. (The Deltoides, Pyrales, Crambites, Tortrices, Tineæ, and Pterophori.) Edited by Geo. T. Porritt. xviii $+420+34$ pp., 17 plates (cxlviiiclxiv). 8vo. 1901.

\section{For the Fifty-seventh Year, 1900.}

78. Monograph of the Coccidæ of the British Isles. By Robert Newstead. Vol. I. xii $+220+78$ pp., 39 plates (A-E, i-xxxiv). 8vo. 1901.

\section{For the Fifty-eighth Year, 1901.}

79. British Tyroglyphidæ. By Albert D. Mrchaed. Vol. I. $\mathrm{xvi}+294+44$ pp., 22 plates $(\mathrm{A}-\mathrm{C}, \mathrm{i}-\mathrm{xix}) .8$ vo. 1901.

\section{For the Fifty-ninth Year, 1902.}

80. Monograph of the Coccida of the British Isles. By Robert Newstead. Vol. II. viii $+270+84$ pp., 42 plates (F, $\mathrm{xxxv-l \times xv).} \mathrm{8vo.} 1903$.

\section{For the Sixtieth Year, 1903.}

81. British Tyroglyphidæ. By Albert D. Michael. Vol. II. xii $+184+40$ pp., 20 plates $(\mathrm{xx}-\mathrm{xxxix}) . \quad 8$ vo. 1903.

\section{For the Sixty-first Year, 1904.}

82. A Monograph of the British Desmidiacex. By W. and G. S. West. Vol. I. xxxvi $+224+64$ pp., 32 plates. 8 vo. 1904 .

83. British 'Tunicata. By the late Joshua Alder and the late Albany Hancock. Edited by John Hopkinson. Vol. I. With a History of the Work by Canon A. M. Norman. xvi $+146+42$ pp., 20 plates, and frontispiece. 8vo. 1905 .

\section{For the Sixty-second Year, 1905.}

84. A Monograph of the British Desmidiaceæ. By W. and G. S. West. Vol. II. $\mathrm{x}+206+64$ pp., 32 plates. 8vo. 1905.

85. The British Freshwater Rhizopoda and Heliozoa. By JAMES CASH, assisted by JoHn Hopkinson. Vol. I. 'I'he Rhizopoda, Part I. $x+150+32$ pp., 16 plates. 8 vo. 1905. 
For the Sixty-third Year, 1906.

86. The British 'Tunicata. By the late JoshoA Alder and the late Arbany Hancock. Edited by John Hopkinson. Vol. II. With Lives of the Authors by Canon Norman and Dennis Embleton. xxviii $+164+62$ pp., 30 plates $(x x i-1)$, and frontispiece. 8vo. 1907.

\section{For the Sixty-fourth Year, 1907.}

87. A Monograph of the British Annelids. By Willian Carmichael McIntosh. Vol. II, Part 1. Polychæta. Nephthỵdidæ to Syllidæ. viii $+232+46$ pp., 22 plates (xliii-1, lvii-lxx). Folio. 1908.

For the Sixty-fifth Year, 1908.

88. A Monograpl of the British Desmidiacex. By W. and G. S. West. Vol. III. xvi $+274+62$ pp., 31 plates $(\mathrm{lxv}-$ xcv). 8vo. $190 \overline{8}$.

89. The British Freshwater Rhizopoda and Heliozoa. By the late James Cash, assisted by John Hopkinson. Vol. II. The Rhizopoda, Part II. xviii $+168+32$ pp., 16 plates (xvii-xxxii), and frontispiece. 8vo. 1909.

For the Sixty-sixth Year, 1909.

90. The British Nudibranchiate Mollusca. By the late Joshda Alder and the late Albany Hancock. Part 8 (supplementary). Text by Sir Charles Eliot. viii $+198+18$ pp., 8 plates. Folio. 1910.

\section{For the Sixty-serenth Year, 1910.}

91. A Monograph of the British Annelids. By WiLliam Carmichael McIntosh. Vol. II, Part 2. Polychæta. Syllidæ to Ariciidæ. vii $+292(233-524)+46$ pp., 23 plates (li-lvi, lxxi-lxxxvii). Folio. 1910.

\section{For the Sixty-eighth Year, 1911.}

92. A Monograph of the British Desmidiaceæ. By W. and G. S. WEST. Vol. IV. xiv + $194+66$ pp., 33 plates (xcvi-cxxviii). 8vo. 1912.

93. The British Tunicata. By the late JoshuA Alder and the late Albany Hancock. Edited by Joun Hopkinson. Vol. III. xii $+114+34$ pp., 16 plates (li-lxvi), and frontispiece. 8vo. 1912. 
For the Sixty-ninth Year, 1912.

94. A Bibliograpliy of the 'Tunicata. Вy John Hopkinsox. xii +288 pp. 8vo. 1913.

95. The British Parasitic Copepoda. By Dr. Thomas Scotт and Andrew Scott. Vol. I (Copepoda parasitic on Fishes, Part I). xii +256 pp., 2 plates. 8vo. 1913.

\section{In Course of Publication.}

The British Desmidiaceæ. By W. West and Prof. G. S. WEST.

The British Freshwater Rhizopoda and Heliozoa. By the late Jamres CASH and (after Tol. II) G. H. Wailes.

The British Marine Amelids. By Prof. W. C. McIstosu.

The British Parasitic Copepoda. By Dr. Thomas SсотT and Andrew Scotr. (Vol. II for 1913.)

\section{Preparing for Publication.}

The British Centipedes and Mrillepedes. By W. M. WeBs. The British Earthworms. By the Rev. Hilderic Friend. 'The British Hydrachnida. By C. D. Sost and IV. WiLliamson.

The British Ixodoidea. By W. F. Cooper and L. E. Robinson. 'The Earwigs of the World. By Dr. Matcolin Burr.

Narch, 1913. 

THIS BOOK IS DUE ON THE LAST DATE STAMPED BELOW

AN INITIAI FINE OF 25 CENTS WILL BE ASSESSED FOR FAILURE TO RETURN THIS BOOK ON THE DATE DUE. THE PENALTY WILL INCREASE TO $5 O$ CENTS ON THE FOURTH DAY AND TO \$1.00 ON THE SEVENTH DAY OVERDUE.

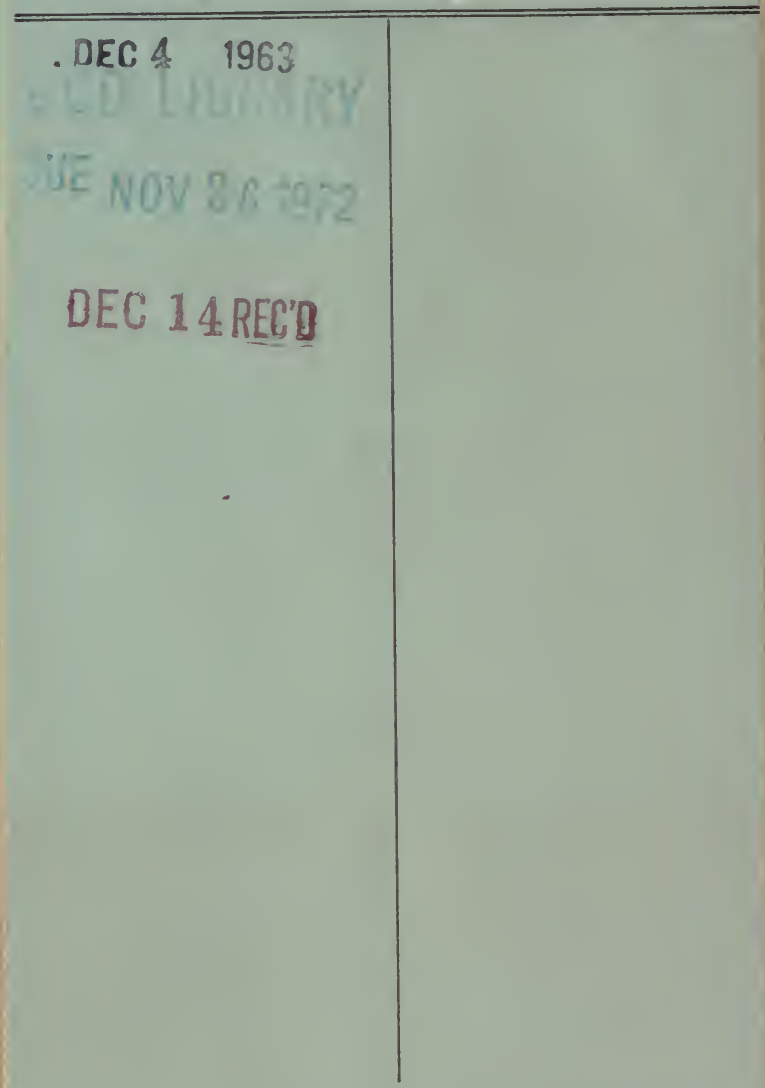

Book Slip-10m-8,'51 (6813s4)458 
$5 c p=6$

\section{Q1.474 \\ C 7 \\ 53 \\ V.I}

81189 
